\title{
CARACTERIZAÇÃO E GÊNESE DE FERRICRETES DESENVOLVIDOS DO ARENITO BAURU, FORMAÇÃO ADAMANTINA (Ka), NO MUNICÍPIO DE PINDORAMA (SP)
}

\section{MAURÍCIO RIZZATO COELHO}

Engenheiro Agrônomo

Orientador: Prof. Dr. PABLO VIDAL TORRADO

\begin{abstract}
Dissertação apresentada à Escola Superior de Agricultura "Luiz de Queiroz", Universidade de São Paulo, para a obtenção do título de Mestre em Agronomia, Área de Concentração: Solos e Nutrição de Plantas.
\end{abstract}

P IR A C I C A B A

Estado de São Paulo - Brasil

Dezembro - 1998 


\section{ERRATA}

\section{- EM TODO O TEXTO:}

- Onde se lê "goetita" substituir por goethita.

- Onde se lê "argílico" substituir por textural.

- Página xvi, $2^{\circ}$ parágrafo, $8^{\mathrm{a}}$ linha, leia-se: "Estudaram-se três perfis no terço final da vertente, sendo que dois localizam-se na baixa meia encosta e um no sopé"...

- Página 2, $18^{\mathrm{a}}$ linha, leia-se: "Nenhum desses estudos relata a ocorrência de níveis ferricretizados na paisagem, o que leva a pensar numa diferente natureza geoquímica daqueles sedimentos."

- Página $6,2^{\circ}$ parágrafo, $6^{\mathrm{a}}$ linha, leia-se: "Petroplintita: material rígido, normalmente proveniente do endurecimento irreversível da plintita."

- Página 29, $2^{\circ}$ parágrafo, $23^{\mathrm{a}}$ linha, leia-se: "2) diminuição dos cristais de caulinita com o aumento da substituição do Al por Fe nas folhas octaedrais;"

- Página 44, Figura 7, leia-se: "Arenito do Grupo Bauru"

- Página 53, $9^{\mathrm{a}}$ linha, leia-se. "Guillet \& Jeanroy (1985)"...

- Página 73, legenda da Figura 12, leia-se: "A) Glébulas irregulares $(2,3 \mathbf{~ c m ~ d e ~}$ diâmetro)" predominantes no horizonte petroplíntico (F1);"

- Página 75, último parágrafo, $2^{\text {a. }}$ linha: substituir "(Figura do Mapa de Solos)" por (Figuras 6 e 7).

- Página 78, penúltima linha, leia-se: "A significativa presença de feldspatos do grupo dos plagiocásios foi evidenciado por Lepsch et al. (1978)"...

- Página $84,1^{\circ}$ parágrafo, $1^{\text {a }}$ linha: substituir " $A F^{\prime}$ " por AMF.

- Página 104, final do $2^{\circ}$ parágrafo, leia-se: "Os mecanismos envolvidos na formação dessas glébulas já foram discutidos nos resultados morfológicos."

- Páginas 119, 123, 126 e 130, Figuras 21, 22, 23 e 24. Para o perfil P3, a seqüência de horizontes no gráfico é: A, EA, E, Btg1 e Btg2. O horizonte E não apresenta o subscrito g.

- Página 140, antepenúltima linha, leia-se: "No entanto, esses mesmos autores, citando o trabalho de Navalovic, afirmam que metais pesados, tais como $\mathrm{Mn}$ e $\mathrm{Cu}$, podem coprecipitar com ferridrita"...

- Página 186, legenda da Figura 51, leia-se: "Fotomicrografia mostrando uma glébula plíntica do horizonte $\mathrm{Cr}$ (perfil P2). Diferentes domínios "cruzam" a glébula, originando verdadeiros "corredores" que ora são preenchidos com plasma apenas (paleocanais biológicos), ora com plasma e quartzo triado na fração silte (paleopedotúbulos). Essa morfologia só é explicada pela atuação da atividade biológica (LN - 2,5x)."

- Página 188, legenda da Figura 53, leia-se: "Fotomicrografia das glébulas petroplínticas dos perfis P1 e P2 (LN - 10x)."

- Página 196, Figura 56. Na Figura C está faltando as indicações dos eixos das coordenadas. Eixo x: E (ev); Eixo Y: Intensidade. 
Dados Internacionais de Catalogação na Publicação (CIP)

DIVISĀo DE BIBLIOTECA E DOCUMENTAÇÃO - Campus "Luiz de Queiroz"/USP

Coelho, Mauricio Rizzato

Caracterização e gênese de ferricretes desenvolvidos do arenito Bauru, formaçăo Adamantina (Ka), no município de Pindorama (SP) / Maurício Rizzato Coelho. Piracicaba, 1998.

$233 \mathrm{p}$.

Dissertação (mestrado) - - Escola Superior de Agricultura Luiz de Queiroz, 1998. Bibliografia.

1. Arenito 2. Degradaçāo 3. Formação do solo 4. Laterita 5. Mineralogia 6. Morfologia I. Título 


\section{Ofereço}

Ao meu pai João Baptista Marcondes Coelho e a minha mãe Ida Rizzato Coelho como forma de agradecimento por tudo aquilo que vocês fizeram e representam para mim. Meu amor é tão grande quanto a minha admiração por vocês.

Dedico

À Denise, à meus irmãos Dimas, Ricardo, João Henrique, Maria Teresa e Maria Cláudia, pelo companheirismo e carinho incondicionais. 
Agradecimentos

Ao Prof. Dr. Pablo Vidal Torrado pela amizade, compreensão e orientação valiosas, imprescindiveis no desenvolvimento deste trabalho.

À CAPES pelo apoio financeiro, sem o qual a pesquisa não seria realizável.

À Escola Superior de Agricultura "Luiz de Queiroz" pela oportunidade.

Ao Instituto Agronômico por ter permitido essa qualificação.

À turma da Estação Experimental de Pindorama, pela grande colaboração na execução dos trabalhos de campo. Agradecimento especial aos colegas Lúcio e Luís Cláudio pelo companheirismo e facilidades concedidas.

Aos pesquisadores do IAC Dr. Antonio Carlos Moniz, Dr. Otávio Antonio Camargo e Dr Wanderley Antônio Tremocoldi pela atenção e receptividade sempre que necessário. Agradecimento especial aos pesquisadores Dr. João Roberto Ferreira Menk e Dr. Márcio Rossi, pela amizade, dedicação, incentivo e importantes sugestões apresentadas.

Ao amigo Josef Andreas Nick, pela incondicional amizade.

Ao colega Francisco Sérgio Bernardes Ladeira, pela amizade e auxílio nos trabalhos de campo.

Ao colega Miguel Cooper, pelo companheirismo e apoio técnico.

Aos funcionários do Departamento de Solos da ESALQ, pelo apoio sempre que necessário, especialmente a Bete, João e Luís Silva pela boa vontade de sempre. 


\section{SUMÁRIO}

LISTA DE FIGURAS $\ldots \ldots \ldots \ldots \ldots \ldots \ldots \ldots \ldots$
LISTA DE TABELAS $\ldots \ldots \ldots \ldots \ldots \ldots \ldots$

2.1 Nomenclaturas, terminologias e definições.............................................. 3

2.2 Composição química, morfológica, mineralógica dos ferricretes e mecanismos

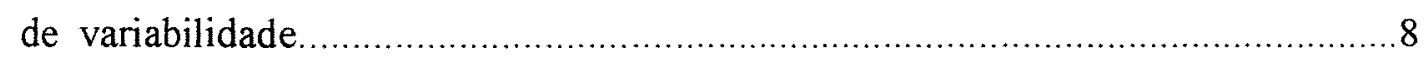

2.2.1 Composição química e mecanismos de variabilidade ................................9

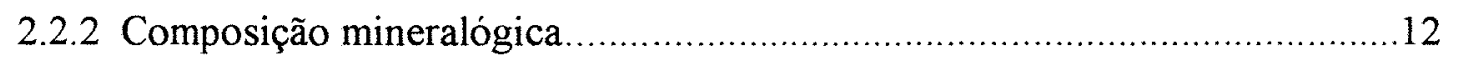

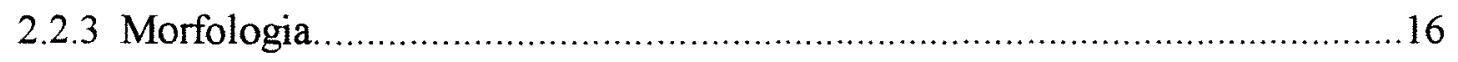

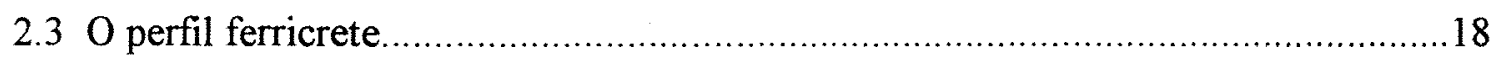

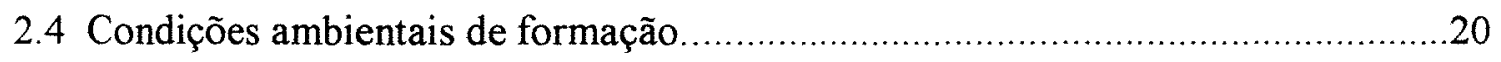

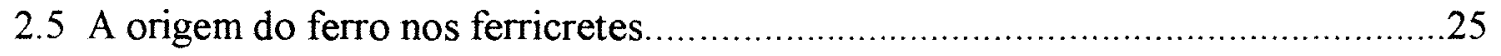

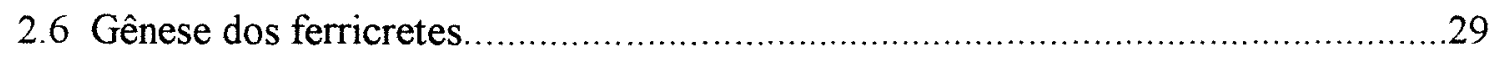

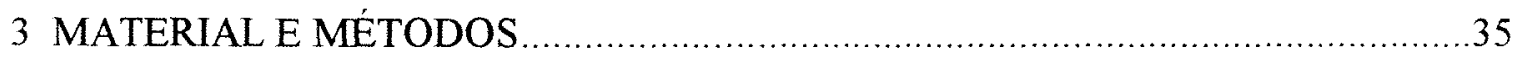

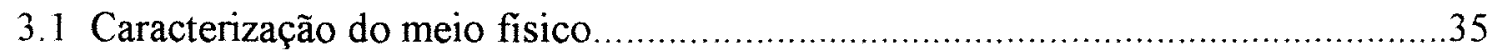

3.1.1 Localização, geologia, geomorfologia, clima e vegetação........................35

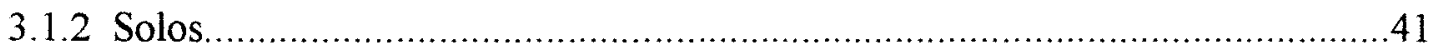

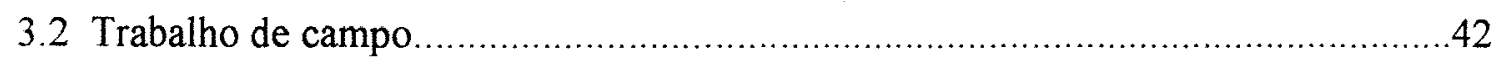

3.2.1 Estabelecimento do segmento de vertente .............................................42

3.2.2 Abertura de trincheiras e amostragem de solos...................................45

3.2.3 Análise estrutural do segmento de vertente............................................45

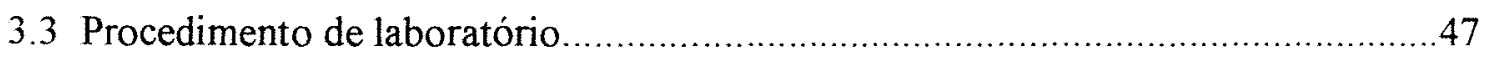

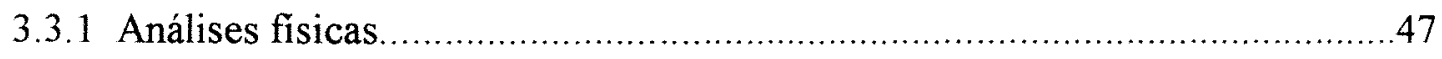

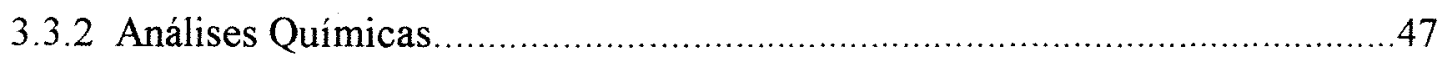

3.3.2.1 Análises químicas de rotina .................................................. 48 
3.3.2.2 Elementos Totais (Ataque Sulfúrico) ...............................................48

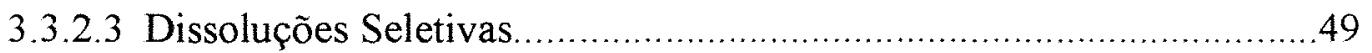

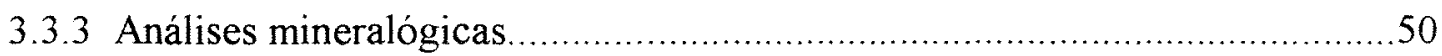

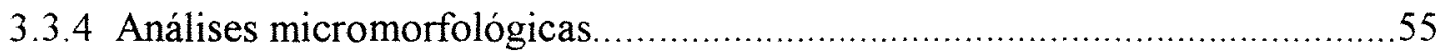

3.3.5 Análises submicroscópicas e microanálise pontual...................................56

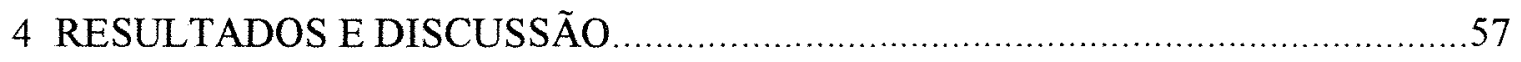

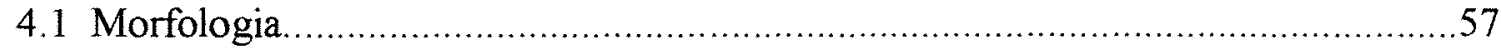

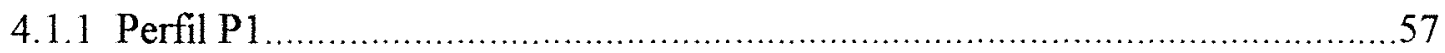

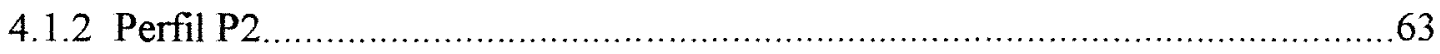

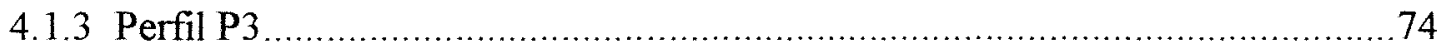

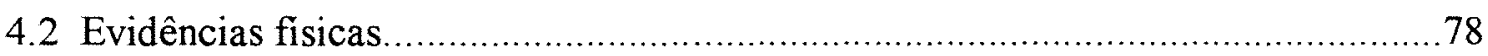

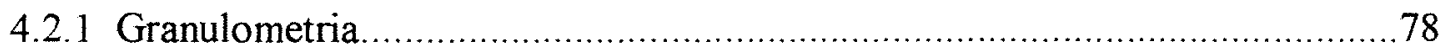

4.2.2 Distribuição de freqüência do tamanho das partículas...................................83

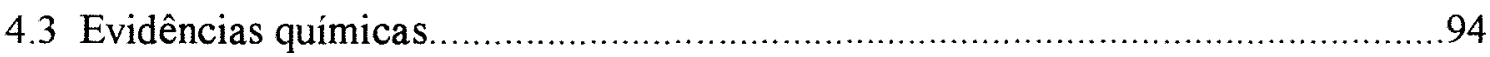

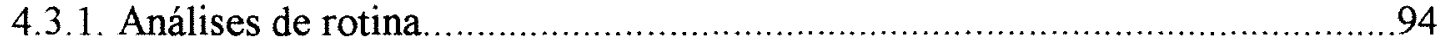

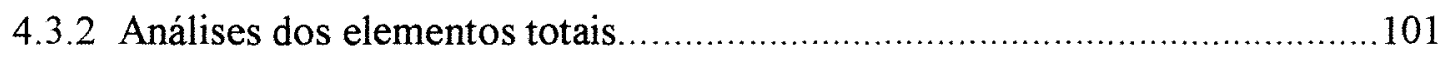

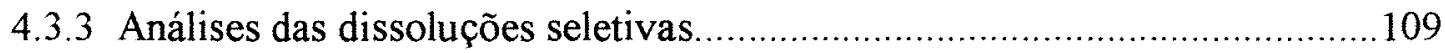

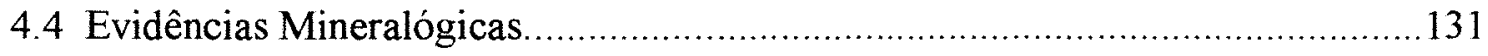

4.4.1 Mineralogia da fração argila desferrificada ...........................................131

4.4.2 Mineralogia dos óxidos de ferro na fração argila.......................................138

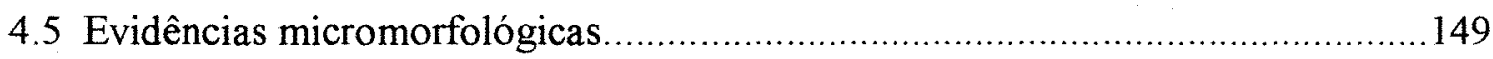

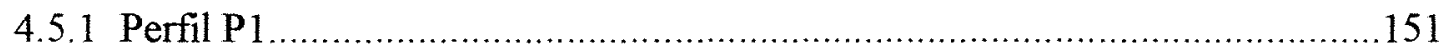

4.5.2 Perfil P2

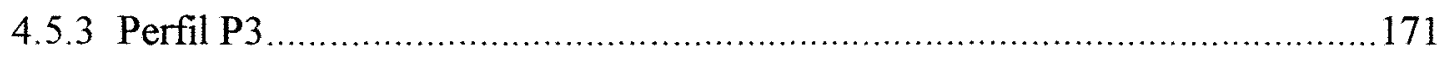

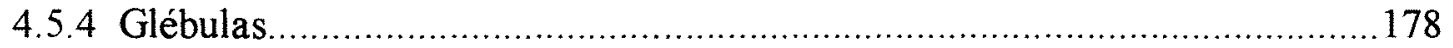

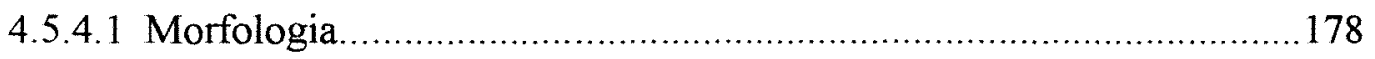

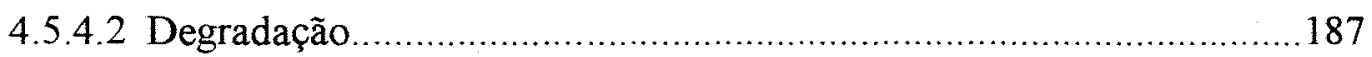

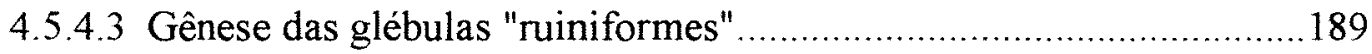

4.6 Evidências submicroscópicas: microscopia de varredura e microanálise.............191

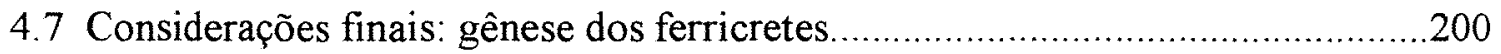




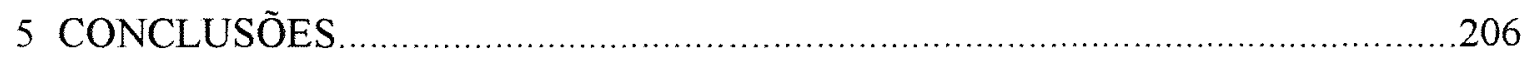

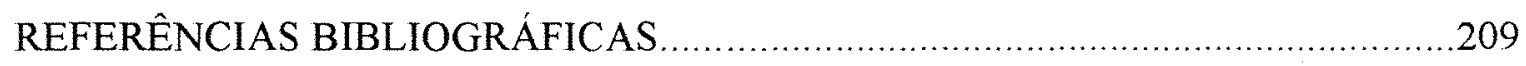

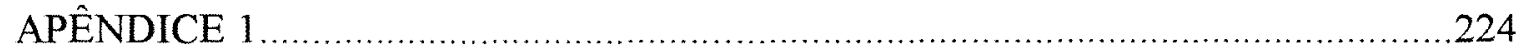

APÊNDICE 2 


\section{LISTA DE FIGURAS}

Página

1 Localização da área estudada no Estado de São Paulo e nas proximidades da Estação Experimental de Pindorama - IAC (SP)

2 Distribuição do Grupo Bauru, formação Itaqueri e correlatas no Estado de São Paulo. Fonte: IPT (1981a). 38

3 Províncias Geomorfólogicas do Estado de São Paulo. Fonte: Oliveira e Menk (1984).

4 Fotomontagem com as localizações da Estação Experimental e da seqüência estudada.

5 Balanço hídrico anual da Estação Experimental de Pindorama (1961 a 1990). P $($ precipitação $)=1390,2 \mathrm{~mm} ; \mathrm{EP}($ Evapotranspiração potencial $)=1129,0 \mathrm{~mm}$; ER (Evapotranspiração real) $=1061,9 \mathrm{~mm}$; deficiência hídrica $=67,1 \mathrm{~mm}$; excedente hídrico $=328,3 \mathrm{~mm}$. Fonte: Centro de Ecofisiologia e Biofisica - Instituto Agronômico (IAC).

6 Mapa de solos da Estação Experimental de Pindorama e localização da seqüência estudada em uma propriedade confrontante à Estação. Fonte: Lepsch \& Valadares (1976).

7 Posição esquemática dos perfis na paisagem

8 Representação esquemática do segmento de vertente estudado com a localização dos perfis P1, P2 e P3 e distribuição lateral e vertical dos diferentes horizontes. 46

9 Fotografia dos perfis P1, P2 e P3 mostrando seus diferentes horizontes e camada. 60

10 Detalhe da transição entre os horizontes F1 (petroplintico) e F2 (plíntico) do perfil P1

11 Perfil oposto ao P1 na trincheira. Notar sinais de hidromorfismo (alto valor e baixos croma) na base do perfil. 
12 Glébulas petroplínticas do perfil P2: A) glébulas irregulares $(1,5 \mathrm{~cm}$ de diâmetro) predominantes no horizonte petroplintico (F1); B) Glébulas "ruiniformes" $(10 \mathrm{~cm})$; C) Nódulo com seu interior enegrecido devido à presença de manganês $(3 \mathrm{~cm}$ no maior eixo).

13 Glébulas plinticas do perfil P2. Notar formas poliédricas, assemelhando-se aos fragmentos do saprolito

14 Histogramas representativos das porcentagens da areias em cada uma das classes granulométricas para todos os horizontes do perfil P1 87

15 Histogramas representativos das porcentagens das areias para todos os horizontes do perfil P2 .88

16 Histogramas representativos das porcentagens das areias para os horizontes do perfil P3 89

17 Gráfico de linhas log-normal comparando a \% acumulada da distribuição granulométrica das areias para os horizontes superficiais dos três perfis estudados ( $25 \mathrm{~cm}$ superficiais). 92

18 Distribuição da matéria orgânica (MO), $\mathrm{pH}$ em KCl $(\mathrm{pH} \mathrm{KCl})$ e soma de bases (SB) com a profundidade para todos os perfis estudados 99

19 Distribuição da saturação em bases (V), CTC à pH 7 (CTC7) e saturação em Alumínio (m) com a profundidade para os perfis estudados

20 Distribuição, com a profundidade, do ferro total $\left(\mathrm{Fe}_{t}\right)$ e dos óxidos de ferro extraídos com ditionito-citrato de sódio (DC), nos perfis P1, P2 e P3 (para os horizontes ferricretes considerou-se apenas sua matriz interglebular)

21 Distribuição em profundidade do ferro extraído com oxalato-oxálico $\left(\mathrm{Fe}_{\mathrm{o}}\right)$ e da relação ferro ativo $\left(\mathrm{Fe}_{\mathrm{o}} / \mathrm{Fe}_{\mathrm{d}}\right)$ para os perfis P1, P2 e P3 (para os horizontes ferricretes, considerou-se apenas sua matriz interglebular). 119

22 Distribuição em profundidade do ferro extraído pelos reagentes oxalato-oxálico $\left(\mathrm{Fe}_{\mathrm{o}}\right)$ e pirofosfato $\left(\mathrm{Fe}_{\mathrm{p}}\right)$ para os perfis $\mathrm{P} 1, \mathrm{P} 2 \mathrm{e}$ P3 (para os horizontes ferricretes considerou-se apenas sua matriz interglebular) 
23 Distribuição em profundidade do alumínio ditionito $\left(\mathrm{Al}_{\mathrm{d}}\right)$ e oxalato $\left(\mathrm{Al}_{\mathrm{o}}\right)$ para os perfis P1, P2 e P3 (para os horizontes ferricretes considerou-se apenas sua matriz interglebular). 126

24 Distribuição em profundidade do manganês extraído com ditionitocitrato $\left(\mathrm{Mn}_{\mathrm{d}}\right)$, oxalato-oxálico $\left(\mathrm{Mn}_{\mathrm{o}}\right)$ e hidroxilamina $\left(\mathrm{Mn}_{\mathrm{h}}\right)$ para todos os perfis estudados (para o horizonte ferricrete considerou-se apenas sua matriz interglebular)......

25 Difratogramas de raio-x da fração argila desferrificada das glébulas petroplinticas (F1-C) do perfis P1 e P2 e plínticas (F2-C) do P1

26 Difratogramas de raio-x da fração argila desferrificada de todos os horizontes e matriz interglebular dos perfis

27 Difratogramas dos óxidos de ferro na fração argila para todos os horizontes, matriz interglebular, camada $\mathrm{R} e$ glébulas dos perfis estudados $144 / 145 / 146 / 147$

28 Esquema de disposição dos horizontes e localização de coleta das amostras indeformadas nos perfis 150

29 Vista geral do horizonte $\mathrm{Cr}(100 \mathrm{a} 110 \mathrm{~cm})$ do perfil $\mathrm{P} 1$; nota-se a deposição dos ferriargilâs na porosidade gerada entre os fragmentos de saprolito (F) e o solo (S), bem como a intensa ferruginização (ferrãs isóticos) concentrada principalmente na proximidade dos poros ( $\mathrm{LN}-2,5 \mathrm{x})$

30 Detalhes dos ferriargilãs da figura anterior. Nota-se a presença de esqueleto na fração areia muito fina, sugerindo iluviação conjunta de argila e quartzo. A acumulação de ferro por difusão nessas estruturas são responsáveis pelas porções isóticas que apagam a orientação forte e contínua, características dos ferriargilãs de iluviação (A - LN 10x; B - LP; 10x). 160 
31 Fotomicrografia mostrando o córtex com maior concentração de plasma e esqueletos finos. Nota-se a presença de plasma com matizes mais amarelos no interior das glébulas, sugerindo menores conteúdos de hematita. A matriz interglebular é porfirica com pequena porosidade cavitária (LN 2,5x)

32 Visão geral do horizonte E nas transição do ferricrete. Nota-se a presença expressiva da porosidade de empilhamento e cavitária, bem como desenvolvimento da trama gefúrica. $\mathrm{O}$ esqueleto mostra-se subarredondado para as frações mais grosseiras e subangulares para finas. (LN 2,5x). 161

33 Fotomicrografia da transição $\mathrm{F} 2 / \mathrm{Cr}$ do perfil P1. Nota-se a presença de uma porosidade metacavitária (C) com cutãs de transformação na sua parede $(\mathrm{LN}-2,5 \mathrm{x})$

34 Detalhe da degradação dos agregados porfiricos com o aumento da porosidade cavitária imediatamente abaixo do horizonte plíntico; observa-se também uma possível dissolução dos grãos de esqueleto associados aos poros. A aparência geral é de desmonte (LN - 2,5x).

35 Fotomicrografia da rocha $(R)$ mostrando a porosidade fissural com impregnações de manganês e ferro na sua parede interna (neomangãs e neoferrãs), estendendo-se a poucos milímetros para o interior do fundo matricial (quasimangãs e quasiferrãs) (LN - 2,5x). 166

36 Detalhes do fundo matricial da rocha com porções dominadas por quartzo fino e plasma. Nota-se que a segregação de ferro já é evidente nessa camada e representado por domínios enegrecidos no plano da lâmina (LN - 2,5x). 166

37 Vista geral da base do horizonte $\mathrm{Cr}$ (140 $\mathrm{cm}$ de profundidade) no perfil P2. Nota-se a existência de glébulas (à direita) bem como a pequena porosidade cavitária (LN - 2,5x).

38 Fundo matricial da transição $\mathrm{F} 2 / \mathrm{Cr}$ evidenciando o aumento da porosidade cavitária e desmonte geral da estrutura porfirica (LN - 2,5x). 
39 Fotomicrografia do horizonte plíntico (F2) do perfil P2. Nota-se a expressiva porosidade (orto e meta cavidades e canais) e presença de cutãs. Sob nícois cruzados, a orientação forte e contínua discrimina os ferriargilãs de iluviação dos cutãs de transformação.

Esses mostram domínios manchados ( $\mathrm{A}-\mathrm{LN}$; $\mathrm{B}-\mathrm{LP} ; 2,5 \mathrm{x})$. 168

40 Fotomicrografia da matriz interglebular no horizonte petroplíntico (perfil P2) evidenciando a restrita porosidade predominantemente cavitária. Nota-se também a triagem do esqueleto intraglebular em relação à matriz friável ( $L N-2,5 x)$. 169

41 Detalhes dos ferriargilãs de iluviação no fundo matricial interglebular do horizonte petroplíntico (perfil P2). Nota-se os bandeamentos no cútan à esquerda (ferriargilã zonado complexo) e o completo caráter isótico no cútan de cima (hematãs) quando observado sob nícois cruzados. Ambos são ferriargilãs de iluviação intensamente ferruginizados (A - LN; B - LP; 10x) .......170

42 Fotomicrografia do horizonte Btg2 no perfil P3. Nota-se o desenvolvimento de uma porosidade entre o mosqueado à direita e o fundo matricial intermosqueado à esquerda. São evidentes tanto a segregação e precipitação do ferro fornecendo colorações mais escuras, como a pequena porosidade no interior dos mosqueados $(\mathrm{LN}-2,5 \mathrm{x})$. 175

43 Fotomicrografia do horizonte Btg1 no perfil P3. Detalhes dos domínios porfiricos e gefúricos com uma significativa porosidade cavitária e de arranjo na transição. Nota-se também a presença de pápulas ainda preenchendo totalmente os poros e não integradas ao fundo matricial. Geralmente estão acompanhadas de esqueleto muito fino $\mathrm{e}$ siltoso ( $\mathrm{LN}-2,5 \mathrm{x})$. 175

44 Domínios porfiricos no horizonte Btg1 com uma porosidade cavitária irregular se coalescendo. Nota-se também, estruturas gefúricas e pápulas destituídas de esqueleto quartzoso. A aparência é de desmonte da estrutura porfirica $(\mathrm{LN}-2,5 \mathrm{x})$ 176

45 Transição E/Btgl evidenciando a coalescência da porosidade cavitária e a 
passagem da estrutura porfirica para chitônica $(\mathrm{LN}-2,5 \mathrm{x})$

46 Morfologia interna das glébulas petroplínticas (A) e plínticas (B). Nota-se a presença de matizes mais amarelos nas plintitas $(L N-2,5 x)$

47 Fotomicrografia das glébulas petroplínticas dos perfis P1 e P2 evidenciando a presença de domínios internos ocupados somente com plasma e pouco esqueleto fino (perfil P1). No entanto, algumas poucas glébulas (perfil P2) também mostram um córtex dominado por plasma e com sua matriz interna predominantemente na fração esqueleto muito fino $(\mathrm{LN}-2,5 \mathrm{x})$

48 Fotomicrografia mostrando glébulas com diferentes granulometrias do esqueleto, presentes lado a lado nos horizontes petroplínticos dos perfis $\mathrm{P} 1$ e $\mathrm{P} 2(\mathrm{LN}-2,5 \mathrm{x})$ 184

49 Fotomicrografia de uma glébula plíntica do perfil P2 evidenciando sua origem associada a atividade biológica. Nota-se o alinhamento dos grãos de esqueleto separando os volumes com quartzo mais fino daqueles de maiores dimensões. $\mathrm{O}$ domínio com esqueleto fino corresponde a um pedotúbulo, o qual se encontra totalmente ferruginizado em alguns locais $(\mathrm{LN}-2,5 \mathrm{x})$.

50 Glébula plíntica do perfil P2. Nota-se o desenvolvimento de plasma no seu interior e esqueleto fino no córtex. As formas aproximadamente arredondadas sugerem paleocanais biológicos, os quais foram posteriormente preenchidos com géis de ferro ou argila iluviada, com posterior ferruginização. Fendas de contração são evidentes nos domínios ocupados por plasma apenas ( $\mathrm{LN}-2,5 \mathrm{x})$

51 Fotomicrografia mostrando uma glébula plíntica no horizonte $\mathrm{Cr}$ (perfil P2). Domínios ocupados com plasma apenas "cruzam" como verdadeiros "corredores" de quartzo fino (pedotúbulos) e plasma (canais biológicos). Essa morfologia só é explicada pela atuação da atividade biológica $(\mathrm{LN}-2,5 \mathrm{x})$. 
52 Pisolito de degradação no horizonte petroplíntico do perfil P2

Nota-se o desenvolvimento de um córtex goetítico com esqueleto fino (silte) que pode ser incorporado ao fundo matricial interglebular $(\mathrm{LN}-2,5 \mathrm{x})$

53 Detalhes do córtex goetítico evidenciando o estágio de degradação das glébulas, bem como a liberação do seu plasma e esqueleto na fração areia muito fina ao fundo matricial interglebular. Fotomicrografia das glébulas plinticas dos perfis P1 e P2 (LN - 10x)

54 Fotomicrografia mostrando a gênese das glébulas "ruiniformes". Nota-se uma "ponte" entre as glébulas, promovendo sua fusão A diferença de granulometria do esqueleto entre o fundo matricial intraglebular e a "ponte" sugere aportes de ferro posteriores à formação das glébulas $(\mathrm{LN}-2,5 \mathrm{x})$

55 Feldspato e gibbsita no interior de uma glébula petroplíntica (perfil P2).

Nota-se o estado de dissolução do feldspato, bem como a origem autigênica da gibbsita (Foto $A-1000 x$; Foto $B-2.000 x$ )

56 Evidências da presença de manganês no interior das glébulas petroplínticas com maior conteúdo do elemento no seu interior. Cobalto e cério estão associados devido a sua adsorção nos óxidos de Mn (McKenzie, 1989). Foto A: deposição de manganês associado com cério e cobalto formando uma película revestindo $\mathrm{o}$ grão de quartzo (1.000x). Foto B: cerianita (glomérulos arredondados e de coloração branca $-2.000 x$ ). Figura $\mathrm{C}$ : análise semi-quantitativa do "coating" de manganês e partículas de cerianita 196

57 Campo de estabilidade da cerianita $\left(\mathrm{CeO}_{2}\right)$, Ce-Lanthanida $\left(\mathrm{Ce}_{2}\left(\mathrm{CO}_{3}\right)_{3} .8 \mathrm{H}_{2} \mathrm{O}\right)$, goetita $(\alpha \mathrm{FeOOH})$, siderita $\left(\mathrm{FeCO}_{3}\right)$, $\mathrm{MnO}, \mathrm{MnO}_{2}, \mathrm{Mn}_{2} \mathrm{O}_{3}$ estimadas a partir da constante de equilíbrio $\log \mathrm{K}_{\mathrm{o}}$. Adaptado de Braun et al. (1990). 


\section{LISTA DE TABELAS}

Página

1 Características relacionadas à cor úmida (TFSA) e a mineralogia da fração argila para o perfil P2

2 Características relacionadas à cor e a mineralogia das glébulas para os perfis P1 e P2.

3 Análise granulométrica ( $\mathrm{em} \%$ ) correspondente a fração menor que $2 \mathrm{~mm}$ e relação $\mathrm{Fe}_{\mathrm{d}} /$ argila dos perfis $\mathrm{P} 1, \mathrm{P} 2$ e P3

4 Cálculos estatísticos da distribuição granulométrica da fração areia, segundo Folk \& Ward (1957) .93

5 Análises pedológicas de rotina para os perfis P1, P2 e P3. .98

6 Análise dos elementos totais (ataque sulfúrico) e dissoluções seletivas para os perfis P1, P2 e P3.

7 Conteúdo relativo dos minerais silicatados e gibbsita na fração argila do solo e glébulas para os perfis P1, P2 e P3

8 Valores de Hematita $(\mathrm{Hm})$, Goetita $(\mathrm{Gt}), \mathrm{R}(\mathrm{Hm} / \mathrm{Hm}+\mathrm{Gt})$ e de substituição isomórfica em alumínio na $\mathrm{Hm}$ (SIHm) e Gt (SIGt) determinada por diferentes procedimentos 


\title{
CARACTERIZAÇÃO E GÊNESE DE FERRICRETES DESENVOLVIDOS DO ARENITO BAURU, FORMAÇÃO ADAMANTINA (Ka), NO MUNICÍPIO DE PINDORAMA (SP)
}

\author{
Autor: MAURÍCIO RIZZATO COELHO \\ Orientador: Prof. Dr. PABLO VIDAL TORRADO
}

\section{RESUMO}

Na paisagem do norte do Estado de São Paulo, no domínio do Planalto Ocidental, ferricretes ocorrem em diferentes niveis topográficos e, apesar de não documentados, constituem feição que se repete com freqüência nas vertentes sobre os arenitos cretáceos do Grupo Bauru, formação Adamantina.

Com o objetivo de estudar a gênese desses ferricretes $\mathrm{e}$ avaliar suas características, bem como dos perfis onde ocorrem, selecionou-se uma vertente com ocorrência de ferricretes e dominada por solos com B textural, situação representativa da paisagem regional. Estudaram-se três perfis no terço final da vertente, dois na baixa meia encosta e um no sopé, cujo substrato rochoso é o arenito da formação Adamantina. A área de estudo localiza-se na Estação Experimental de Pindorama do Instituto Agronômico (IAC). Os resultados foram interpretados com base nas observações de campo, análises pedológicas de rotina, análise estatística da distribuição das areias, dissoluções seletivas, mineralogia da fração argila e dos óxidos de ferro, bem como micromorfologia e observações submicroscópicas, todos realizados nos diferentes horizontes e glébulas dos perfis estudados. 
Identificaram-se três tipos de feições pedológicas associadas ao processo de ferruginização: petroplintita, plintita e mosqueados. O termo ferricrete foi utilizado aqui para designar os materiais ferruginosos endurecidos sem nenhuma implicação genética, incluindo plintita e petroplintita. As glébulas plínticas ocorrem abaixo dos horizontes petroplínticos, tanto nos podzólicos como nos plintossolos pétricos localizados na baixa meia encosta. Os mosqueados foram as únicas feições ferruginosas de um podzólico vermelho amarelo moderadamente drenado situado no sopé da vertente. As glébulas plínticas e petroplínticas são essencialmente de constituição mineral, predominando caulinita, hematita e goetita. Mica, gibbsita, anatásio e mais raramente cerianita complementam a mineralogia da fração argila dessas glébulas, as quais se assemelham em constituição aos demais horizontes dos perfis. Quartzo, feldspatos potássicos (alguns sódicos) e ilmenita compõem a fração areia e silte. A maior presença de minerais primários decomponiveis nas glébulas em relação à matriz do solo, assim como a presença de estrutura da rocha em algumas destas são evidências de que a gênese dos ferricretes está associada à ferruginização do saprolito. Em algumas glébulas petroplínticas, enegrecidas pelo revestimento de manganês (Mn), ocorrem, coprecipitando com esse elemento, concentrações anômalas de cério (Ce) e cobalto (Co).

Nas glébulas petroplínticas foram encontrados os maiores teores de Fe total, livre e amorfo entre todos os horizontes estudados. No entanto, o baixo valor de ferro ativo indica a participação de hematita e goethita bem cristalizadas. Ao contrário, as plintitas mostraram valores de ferro ativo mais elevados devido à sua maior imaturidade em relação às feições petroplínticas.

As glébulas apresentaram diferentes fábricas internas relacionadas à distribuição do esqueleto e plasma: algumas tem esqueleto muito selecionado, com dominância de areia muito fina, enquanto que em outras predomina a areia média; outras, ainda, tem esqueleto pouco selecionado; a grande maioria mostra alguns volumes ocupados por apenas plasma. Fatores pedo-lito-biológicos estão envolvidos nessa diversidade entre glébulas plínticas e petroplínticas num mesmo horizonte.

A gênese dos horizontes petroplínticos está relacionada à lixiviação do ferro ferroso da paisagem à montante e deposição na superficie do lençol freático. Condições 
alternantes de umidecimento e secagem condicionadas pela oscilação do lençol, favoreceram a precipitação e segregação do ferro "em massa". No entanto, a mobilização do elemento foi acompanhada por processos pedogenéticos de transferência de matéria e rebaixamento da paisagem durante a gênese dos ferricretes. Atualmente essas feições petroplínticas estão se degradando, fornecendo ferro para a formação dos materiais plínticos sotopostos.

Um conjunto de processos como a e-iluviação das argilas, degradação destas por hidromorfia temporária, aportes de colúvios e a degradação dos horizontes petroplínticos, contribuíram para a formação do solum acima do ferricrete. A segregação e precipitação do ferro na forma de petroplintita, sua degradação e a formação da plintita, complementam a complexa história pedogenética atuante no terço final da vertente estudada. 


\title{
CHARATERIZATION AND GENESIS OF FERRICRETES FORMED FROM \\ THE BAURU SANDSTONE, ADAMANTINA FORMATION (Ka), IN \\ PINDORAMA (SP)
}

\author{
Author: MAURÍCIO RIZZATO COELHO \\ Adviser: Prof. Dr. PABLO VIDAL TORRADO
}

\section{SUMMARY}

In the landscape of the northern part of the State of São Paulo, in the Occidental Plateau domain, ferricretes occur in different topographic levels and, although not documented, constitute a feature that appear frequently on the toposequences over Cretaceous sandstone of the Bauru Group, Adamantina formation.

With the objective of studying these ferricretes and evaluate their characteristics, as well as the profiles where they occur, a toposequence was selected with the presence of ferricretes and dominated by soils with an argillic horizon, representative situation of the regional landscape. Three profiles were studied on the lower part of the toposequence, two on the backslope and one on the footslope, which parent material is the sandstone from the Adamantina formation. The studied area is situated in the Pindorama Experimental Station of the Agronomic Institute (IAC). The results were interpreted based on field observations, routine pedological analysis, statistical analysis of the sand distribution, selective dissolutions, clay and iron oxide mineralogy, as well as micromorphology and sub-microscopic observations, all done in the different horizons and glebules of the studied profiles. 
Three types of pedological features were identified associated to the ferruginization process: petroplinthite, plinthite and mottles. The term ferricrete was used to designate those hardened ferruginous materials without any genetic implication, including plinthite and petroplinthite. The plinthic glebules occur under the petroplinthic horizons, in the podzolic soils as well as in the petric plintosols located on the lower backslope. The mottles were the only ferruginous features of the red yellow podzolic soil moderately drained situated on the footslope. The plinthic and petroplinthic glebules are essentially of a mineral composition, predominating kaolinite, hematite and goethite. Mica, gibbsite, anatase and rarely cerianite complement the clay mineralogy of these glebules, which are similar in constitution to the rest of the profile's horizons. Quartz, potassic feldspaths (some sodic) and ilmenite compose the sand and silt fractions. The higher presence of decomposable primary minerals in the glebules in relation to the soil matrix as well as the presence of the parent material's structure in some of these are evidences that the formation of the ferricretes is associated to the ferruginization of the saprolite. In some petroplinthic glebules, blackened by manganese (Mn) coatings, occur, coprecipitating with this element, anomalous concentrations of cerium $(\mathrm{Ce})$ and cobalt (Co).

In the petroplinthic glebules higher contents of total, free and amorphous Fe were found in all the studied horizons. Notwithsatnding, the low activity ratio indicates the participation of hematite and well cristallized goethite. On the contrary, the plinthites showed higher active iron values due to their higher imaturity in relation to the petroplinthic features.

The glebules presented different internal fabrics related with the coarse fraction and plasma distribution: some have highly selected coarse fractions, with the dominance of very fine sand, whereas in others medium sized sand predominates; others, have a lowly selected coarse fraction; the great majority show some volumes occupied only by plasma. Pedo-litho-biological factors are involved in this diversity between plinthic and petroplinthic glebules in a same horizon.

The genesis of the petroplinthic horizons id related to the leaching of ferrous iron of the higher landscape and deposition on the surface of the water table. Alternate 
conditions of wetting and drying conditioned by the oscillation of the water table, favour the precipitation and segregation of iron "in mass". Notwithsatnding, the mobilization of the element was accompanied by pedogenetic processes of matter transfer and lowering of the landscape during the ferricrete genesis. Actually these petroplinthic features are degrading, freeing iron for the formation of the underlying plinthic materials.

A group of processes as clay e-iluviation, degradation of these by temporary hydromorphy, colluvium deposits and the degradation of the petroplinthic horizons, contribute to the formation of the solum above the ferricrete. The segregation and precipitation of iron in the form of petroplinthite, its degradation and the formation of plinthite, complement the complex pedogenetical history acting on the lower part of the toposequence. 


\section{INTRODUÇÃO}

Há quase dois séculos atrás, em 1807, Buchanan sugeriu o termo laterita (do latim o termo later significa tijolo) para designar um material avermelhado apropriado para construções de casas. De lá para cá muito se evoluiu nos estudos dos materiais ferruginosos endurecidos de ampla ocorrência nas regiões tropicais, uma vez que os fenômenos de laterização são fundamentais ao geólogo, interessado nos recursos minerais correlato, ao geormorfólogo preocupado com a evolução do relevo tropical, bem como ao pedólogo, no aproveitamento agrícola dos solos. Essa abrangência interdisciplinar favoreceu a inexistência de uma linguagem comum entre os diferentes especialistas que lidam com as lateritas, e muita confusão ainda perdura em torno da definição do assunto. Assim, o termo ferricrete foi escolhido aqui para caracterizá-lo e elucidar os diversos mecanismos envolvidos na gênese dos materiais ferruginosos endurecidos.

A ocorrência de niveis ferruginizados é freqüente em solos derivados da formação Adamantina, região norte do Estado de São Paulo, onde, muitas vezes, ocorrem perfis completamente dominados por essas feições. Esses materiais se apresentam divergentes nos perfis quanto à profundidade de ocorrência, quantidade, espessura do horizonte ferricrete, padrão de distribuição, morfologia, classes e atributos dos solos onde ocorrem e posição que ocupam na paisagem. Assim, sua presença e diversificações nas formas de ocorrência podem afetar significativamente o comportamento físico-químico dos solos, fenômenos ainda pouco conhecidos (Batista \& Santos, 1995). Mais particularmente, esses materiais podem alterar os atributos dos solos, tais como: densidade aparente, capacidade de retenção de água, infiltrabilidade, erodibilidade, volume de solo explorado pelas raizes, capacidade de troca cationica (CTC), textura e estrutura, fatores que 
influenciam na resposta hidrológica, bem como na produtividade dos solos. Portanto, o conhecimento da dinâmica de formação e evolução dos ferricretes e dos solos que desenvolvem essas feições ferruginosas no perfil, bem como as peculiaridades que afetam seu comportamento fisico-químico, devem ser elucidadas para que se possa proceder ao uso e manejo adequado desses solos. Com essa intenção, o estudo dos ferricretes dos baixos níveis topográficos na Estação Experimental de Pindorama do Instituto Agronômico de Campinas constitui a etapa inicial de um projeto maior que visa estabelecer um estudo integrado da geomorfologia, estratigrafia, pedologia e geoquímica de superficie das paisagens sob domínio dessas feições ferruginosas e localizadas na região norte do Estado de São Paulo, onde o substrato rochoso seja a formação Adamantina, do Grupo Bauru. Para essa formação geológica, apesar da vasta extensão que ocupa no oeste do Estado, foram raros os estudos que procuram avaliar as características e elucidar a gênese de seus solos. No entanto, um número considerável de trabalhos acerca da gênese de solos derivados dos sedimentos da formação Marília, membro mais recente do Grupo Bauru, tem sido realizados no Estado de São Paulo (Castro, 1989; Jimenez Rueda \& Demattê, 1988; Lepsch et al., 1977a, b e Marques Júnior, 1995). Nenhum desses estudos relata a ocorrência de níveis ferricretizados na paisagem, o que leva a pensar numa provável natureza geoquímica daqueles sedimentos.

Com vista a estes aspectos é que foi proposto o presente trabalho com o principal objetivo de caracterizar as diferentes feições ferruginosas e os perfis onde ocorrem, bem como elucidar os mecanismos envolvidos na sua gênese. Dentre as principais questões a serem respondidas estão: a relação genética entre as diferentes feições ferruginosas, os variados mecanismos envolvidos na sua formação, a origem do ferro e a relação pedogenética entre os horizontes dos perfis. Para tanto, foram selecionados três perfis de solos desenvolvidos da formação Adamantina e localizados no sopé de uma vertente dominada por feições plínticas, petroplínticas e mosqueados. 


\section{REVISÃO DE LITERATURA}

\subsection{Nomenclaturas, terminologias e definições}

É vasta a literatura que aborda a gênese de materiais ferruginosos endurecidos. Similar situação encontra-se na diversidade de terminologias, definições e interpretações genéticas desses materiais, uma vez que é freqüente na literatura nomes semelhantes se referirem a materiais diferentes ou reversamente, materiais similares com diversas nomenclaturas, ou ainda a adjetivação desses materiais de acordo com sua evolução genética ou características morfomineralógicas (ferricrete de lençol, ferricrete concrecionário, rocha ferricretizada, laterita pisolítica, etc.). Essa confusão tem sua herança a partir da definição do termo laterita, o qual é atribuido a Buchanan que, em 1807, descreveu em Malabar, Índia, materiais usados como tijolos para construção de casas (Sivarajasingham et al., 1962). Os autores que sucederam a Buchanan empregaram o termo para designar materiais endurecidos ou que se endurecem ao ar. No entanto, laterita foi, desde logo, motivo para discussão de sua definição (Maignien, 1966) e seu significado tornou-se confuso e contraditório (Aleva, 1994; Bourman, 1993; Eswaran et al., 1990; Ollier, 1991 e Tardy, 1992). Para Alexander \& Cady (1962), lateritas foram consideradas materiais endurecidos ou capazes de endurecer quando expostos a periodos alternados de umidecimento e secagem. Para outros autores, empregava-se o termo com um significado mais abrangente, servindo para designar os produtos de decomposição das rochas silicatadas sob climas tropicais (latossolização), endurecidos ou não, caracterizados pelo predomínio de hidróxidos de ferro e alumínio (Tardy, 1993). Assim, laterita "é talvez um dos mais mal empregados termos na ciência da terra" (Eswaran et al., 1990, p.109). Essas diferenças nas terminologias e interpretações genéticas são 
parcialmente devido a um gama de profissionais nas diferentes áreas da ciência da terra que lidam com as lateritas (Bigarella et al., 1996, Eswaran et al., 1990 e Schellmann, 1981), associado a grande diversidade petrográfica e morfomineralógica do material (Tardy, 1992). Em vista disto, torna-se relevante e necessário o esclarecimento das nomenclaturas e definições dos materiais ferruginosos aqui estudados e que predominam na literatura nacional e internacional mais recente.

Existe um esforço mundial no sentido de criar uma linguagem e descrição comuns às lateritas, incluindo os materiais ferruginosos endurecidos. Muitos encontros internacionais foram organizados, trabalhos publicados e temas como a padronização do termo laterita e formas relacionadas foram enfatizados, objetivando uma linguagem universal entre as diferentes áreas da ciência da terra (Aleva, 1994). Essas informações foram compiladas por Aleva (1994, p.13) que adotou a seguinte definição para laterita, citando o trabalho de Schellmann ${ }^{1}$ :

'Lateritas são produtos do intenso intemperismo subaéreo das rochas. Elas consistem predominantemente de uma assembléia mineral composta de goetita, hematita, hidróxidos de alumínio, minerais de caulinita e quartzo. A relação $\mathrm{SiO}_{2}:\left(\mathrm{Al}_{2} \mathrm{O}_{3}+\mathrm{Fe}_{2} \mathrm{O}_{3}\right)$ da laterita deve ser menor que seu material de origem caolinitizado no qual todo o alumínio deste material está presente na forma de caulinita, todo o ferro na forma de óxidos e no qual a sílica está, em grande parte, fixada como caulinita e quartzo primário".

Segundo esta definição e interpretação do autor, lateritas são consideradas rochas, são independentes de uma interpretação genética, excluem saprolito como componente laterítico (Schellmann, 1981) e podem incluir tanto produtos residuais como de acumulação absoluta de ferro (Schellmann, 1994). No entanto, trabalhos recentes como de Bourman (1993), Ollier (1991), Tardy (1992), Tardy (1993), Tardy e Roquin

\footnotetext{
${ }^{1}$ SHELLMANN. W. A new definition of laterite. Natural Resources and Development, v.19, p.7-21, 1983.
} 
(1992) e Trolard e Tardy (1989), utilizam o termo com um significado mais abrangente, como pode ser verificado no enunciado de Tardy (1992):

"Assim, o termo laterita inclui bauxitas, ferricretes, crostas endurecidas de ferro e alumínio, horizontes mosqueados, carapaças, couraças, plintitas, pisolitos ou materiais em torno dos nódulos, sendo estendido para as formações ou horizontes os quais são partes dos solos ferralíticos vermelho ou amarelos, solos ferruginosos tropicais e outras formações, tais como litomargas cauliniticas, as quais são macias e não são capazes de endurecer..."

Portanto, fica evidente em tempos atuais, a permanência da complexidade e divergências em torno da definição de laterita. Desde sua criação por Buchanan, diversos termos relacionados foram criados, aperfeiçoados nas suas definições e até mesmo sugerido o abandono do termo laterita (Maignien, 1966). Muitos surgiram em função da diversidade dos materiais ferruginosos. Algumas dessas terminologias estão enunciadas abaixo e, embora haja divergências no seu significado, suas definições correspondem as mais recentes interpretações dos autores, as quais foram adotadas neste trabalho:

Plintita: consiste de corpos avermelhados enriquecidos em ferro, com baixo conteúdo de matéria orgânica. Os corpos apresentam-se com espessura de 5 a $20 \mathrm{~mm}$ na sua menor dimensão e são coerentes o bastante para serem separados do solo circundante. São firmes ou muito firmes quando úmidos e duros ou muito duros quando secos, porém podem ser quebrados com a mão. Apresentam-se com formas aproximadamente esférica, nodulares ou planas. Plintita são corpos que quando expostos a ciclos sucessivos de umidecimento e secagem, endurecem irreversivelmente, transformando-se em petroplintita. Mosqueados enriquecidos em ferro e que não endurecem irreversivelmente quando expostos à atmosfera não são considerados plintita (Daniels et al., 1978). Corresponde a uma das etapas do processo de segregação do ferro, compreendida entre mosqueado e concreção, com a qual está normalmente associada (Fedoroff \& Eswaran, 1985). 
Plintita é um termo relativamente recente, sendo resultado do descontentamento dos cientistas de solo com relação ao uso do termo laterita (Aleva, 1994). Schellmann (1981, p.9) propõe chamar de "laterita de Buchanan" aos materiais que endurecem quando expostos, e acrescenta que é essencialmente o mesmo material hoje caracterizado como plintita.

Petroplintita: material rigido, normalmente proveniente do endurecimento irreversivel da petroplintita. Sua consolidação é atribuido a ciclos repetidos de hidratação e desidratação, dando normalmente lugar à formação de concreções, couraças ou carapaças ferruginosas. Portanto, essas formações que apresentam dimensões e formas variáveis, podem estar individualizadas ou aglomeradas, ou mesmo configurar camadas maciças, contínuas e de espessura variável. (Curi et al., 1993). Esse termo é substituído pelas fases petroférrica e esquelética na Legenda dos Mapas de Solo do Mundo (FAO, 1994).

Plintita e petroplintita recebem a denominação de laterita pedogenética por alguns geomorfólogos (Aleva, 1994);

Couraça ferruginosa: Acumulações endurecidas de ferro na forma de hematita, goetita, podendo conter importantes concentrações de caulinita e quartzo. Gibbsita pode estar presente em pequenas proporções. Sua estrutura é geralmente nodular ou pisolítica, raramente maciça ou vermiforme. Couraça é sinônimo de ferricrete segundo Tardy (1993);

Carapaça: Acumulação endurecida composta principalmente de caulinita, goetita e hematita, as vezes com grandes proporções de quartzo. Uma carapaça é uma formação endurecida, intermediária entre um horizonte mosqueado e uma couraça (Tardy, 1993);

Concreções: uma massa compacta ou agregado de matéria mineral de consistência dura, com formas esféricas tendendo a oval, podendo apresentar-se planos ou irregulares, geralmente com contornos complexos (Aleva, 1994) e supostamente formados por um processo de cimentação e endurecimento devidos a uma acumulação de material, concentrados de maneira centrípeta dentro dos domínios de porosidade fina (Tardy, 1993); 
Nódulos: é uma acumulação de matéria mais ou menos endurecida, de forma aproximadamente arredondada e que não apresenta qualquer diferenciação estrutural interna. Dentro dos solos tropicais, os nódulos variam desde milimétricos (micronódulos) até centimétricos (macronódulos) (Tardy, 1993) e exibem uma composição contrastante em relação à matriz circundante ou a rocha na qual está inserido (Aleva, 1994);

Glébulas: feição pedológica que se distingue do fundo matricial por uma grande concentração de matéria. Glébula é um nome genérico que engloba manchas, nódulos e pisolitos quando considerados dentro do fundo matricial onde são formados (Tardy, 1993);

Feições ferruginosas: termo genérico utilizado para designar as diversas formas de acumulação de ferro, quais sejam: mosqueados, plintita e materiais endurecidos.

Pisolitos: são glébulas circundadas por um ou uma série de córtex. Existem basicamente dois modos de formação dos pisolitos. O primeiro, mais amplamente difundido, corresponde a nódulos que se degradaram por hidratação, formando um córtex geralmente goetítico, comum na superficie das couraças ferruginosas. $\mathrm{O}$ segundo, mais raro, são pisolitos de agradação formados por incrustação (Tardy, 1993). Pisolitos apresentam-se em formas semelhantes a ervilha e com diâmetro superior a $2 \mathrm{~mm}$ (Aleva,1994 e McFarlane, 1976);

Ferricrete: termo originalmente sugerido por Lamplug em 1902 para se referir a cascalhos cimentados por óxidos de ferro (Aleva, 1994 e Schwarz,1994). Atualmente, três posições emergem em torno da definição de ferricrete. Primeiro, muitos cientistas utilizam o termo com um significado restrito para se referir ao produto de acumulação relativa (autóctone) de elementos pouco móveis, tais como, ferro, alumínio, silício, elementos traços e minerais primários resistentes ao intemperismo. Esses elementos podem tanto concentrar-se in situ como podem ser transportados a curtas distâncias em solução na água percolante, ou mecanicamente nos produtos de bioturbação (Roquin et al.,1990b e Tardy \& Roquin, 1992). Numa segunda interpretação, Aleva (1994) também restringe o termo a materiais essencialmente alóctones, originários tanto do transporte lateral do ferro em solução, impregnando e precipitando no saprolito ou sedimentos no 
sopé das vertentes, como de material laterítico transportado, com sua posterior deposição na forma de cascalhos, seguido de cimentação por soluções enriquecidas em ferro no seu novo ambiente deposicional. Segundo o autor, esses materiais não são lateritas e propõe classificá-los como lateritóides. Portanto, as interpretações acima consideram a evolução genética dos materiais ferruginosos na definição de ferricrete (autóctone ou alóctone). Ao contrário, Tardy (1993) refere-se a ferricrete como sinônimo de couraça, englobando tanto horizontes nodulares como crostas contínuas dentro do manto regolítico. Similar tendência é observada nos trabalhos de Bourman (1993), Ollier (1991) e Milnes et al. (1985). Esses autores definem ferricrete com um significado mais amplo, sem conotação genética, referindo-se a "depósitos ricos em ferro que são duros ou cimentados. Ferricretes podem se formar numa ampla variedade de situações, tanto in situ como em materiais transportados, porém os problemas na sua definição não necessitam ser tão confusos como são para definição de laterita" (Ollier, 1991, p.171). Assim, nós adotaremos neste trabalho o termo ferricrete para se referir tanto aos horizontes nodulares com sua matriz friável, como às crostas ferruginosas contínuas, sem nenhuma implicação genética, visando caracterizar e elucidar a gênese desses materiais na paisagem. Quando nos reportarmos aos trabalhos que utilizaram o termo "laterita", essa palavra virá citada entre parênteses.

\subsection{Composição química, morfológica, mineralógica dos ferricretes e mecanismos de variabilidade}

A constituição dos ferricretes, além de sua caracterização como constituinte do regolito, possibilita-nos um melhor entendimento da evolução dos sistemas de intemperismo e assim, obter informações imprescindiveis ao estudo dos mecanismos envolvidos na sua gênese, principalmente quando uma filiação é estabelecida com os horizontes e camadas sobre e subjacentes ao horizonte ferricrete. Associado a essas observações, análises microscópicas e submicroscópicas auxiliam na elucidação dos processos, complementando o arcabouço das técnicas utilizadas nos estudos de gênese dos solos e seus constituintes. 


\subsubsection{Composição química e mecanismos de variabilidade}

As "lateritas" e ferricretes apresentam uma ampla variabilidade das caracteristicas morfológicas, químicas e mineralógicas (Alexander \& Cady, 1962, Roquin et al., 1990b e Sivarajasingham et al., 1962) relacionadas a sua idade, grau de evolução e natureza da rocha de origem dos quais eles derivam (Ibanga, 1980 e Roquin et al., 1990ab). Porém, uma característica comum para todas é seu elevado conteúdo de ferro ou alumínio, ou ambos quando comparado aos outros constituintes (Sivarajasingham et al., 1962 e Tardy, 1993), sendo que, quando analisa-se o elemento ferro, seus teores excepcionalmente atingem $75 \mathrm{~g} / \mathrm{kg}$ de $\mathrm{Fe}_{2} \mathrm{O}_{3}$, mas geralmente variam entre 400 e $650 \mathrm{~g} / \mathrm{kg}$ (Tardy, 1993). Essa variedade entre fácies de ferricrete são atribuídas a diversos fatores. Beauvais \& Roquin (1996), Bourman et al. (1987) e McFarlane (1983) resumem essas variações argumentando que ferricretes são os produtos integrados das mudanças pedológicas, geológicas e regimes hidrológicos que se processam durante a evolução da paisagem, imprimindo-lhes características peculiares conforme esses fatores se combinam, embora alguns autores considerem efeitos isolados em seus trabalhos. Esses efeitos ou mecanismos de variabilidade entre fácies de ferricrete podem ser analisados sob diferentes escalas de observação. Tanto a nível regional, como local, "lateritas" mostram um "elevado grau de diversidade química e mineralógica" (Tardy \& Roquin, 1992, p. 408). Observando-se a nível regional, as diversidades climáticas reinantes nos dias atuais entre diferentes localidades, bem como a evolução paleoclimática desde a deriva dos continentes, são consideradas por muitos autores como os principais responsáveis pela diversidade e distribuição espacial das fácies de ferricrete que afloram nas paisagens atuais (Beauvais et al., 1990; Beauvais \& Tardy, 1991; Beauvais \& Tardy, 1993; Tardy et al., 1988; Tardy \& Roquin, 1992 e Tardy et al., 1991). No entanto, a influência do material de origem pode ser significativa nessa variabilidade, principalmente nos primeiros estágios de desenvolvimento dos perfis ferruginosos, onde as caracteristicas químicas e mineralógicas da rocha são retidas no horizonte ferricrete (Beauvais \& Roquin, 1996; Ibanga, 1980; Roquin, 1990; Roquin et al., 1990b e Tardy \& Roquin, 1992). Segundo Roquin et al. (1990b) e Tardy \& Roquin (1992) esses ferricretes 
imaturos e atuais recebem a adjetivação de litodependentes. Os mesmos autores afirmam que a medida que essas fácies tornam-se maduras e mais velhas, a composição mineralógica e química é homogeneizada e a composição da rocha a qual originou as diferentes fácies é quase totalmente perdida. Estes ferricretes mais velhos e maduros são denominados litoindependentes. Assim, "independente da natureza das rochas de origem as quais eles derivam, a composição final é a mesma: pobre em quartzo (5\%) e constituídos principalmente de caulinita (30\%), goetita (35\%) e hematita (30\%)" (Roquin et al., 1990b, p. 127).

Outros mecanismos que processam, agora a nivel local e os quais são responsáveis pela diversidade dentro dos perfis "lateríticos", podem ser observados no trabalho de Debaveye \& Dapper (1987). Segundo os autores, variados tipos de nódulos foram formados sob diferentes condições ambientais, sofreram transporte a curtas distâncias com a evolução da paisagem e hoje encontram-se misturados dentro da mesma cobertura pedológica. Ainda referindo-se as variações locais, podemos citar o trabalho de Roquin (1990), quem atribuiu ao relevo as diferenças mineralógicas e geoquímicas entre ferricretes. Este teria condicionado processos de denudação da paisagem através de muitas fases de erosão diferencial, expondo ferricretes de diferentes idades ou grau de evolução, induzindo a um mosaico ou a uma distribuição espacial de diferentes fácies de material nodular numa mesma toposseqüência. Para o autor, esse mecanismo só é compreensível quando se considera uma evolução vertical da paisagem na gênese dos ferricretes (natureza residual), fato que possibilita uma variação tanto vertical como lateral entre fácies com diferentes graus de evolução numa mesma vertente. Avesso as propostas enunciadas acima, um trabalho recente de Nahon (1991) enfatiza mecanismos geoquímicos como responsáveis pelas variações estruturais, mineralógicas e composição química dos ferricretes em detrimento de fatores externos (principalmente clima). Esses mecanismos, segundo o autor, são complexos e originam-se de repetidas reações de transferências e acumulações de matéria que se desenvolvem dentro do regolito, produzindo uma diversidade de estruturas. Dentre elas, nódulos, crostas ferruginosas maciças e produtos intermediários (crostas conglomeráticas), sendo que cada estrutura 
resulta da evolução da antecedente dentro de um sistema dinâmico em constante permuta de matéria mineral. Essas reações desenvolvem-se simultaneamente através de um sistema geoquímico entitulado "auto-organização".

Embora ferro, alumínio e silício sejam os mais abundantes constituintes dos ferricretes, outros elementos estão freqüentemente associados, porém em menores proporções (Roquin et al., 1990b). Dentre estes, vanádio e crômio considerados elementos pouco móveis, estão presentes principalmente em ferricretes de natureza residual (Roquin, 1990 e Sivarajasingham et al., 1962). Também titânio é outro constituinte comum na maioria das variedades de "laterita", podendo até atingir proporções significativas (Sivarajasingham, 1962). Freqüentemente representam uma acumulação relativa do material parental, (Ibanga, 1980). Manganês pode ocorrer sob várias formas, principalmente amorfas (McKenzie, 1989), porém litioporita e birnessita são as formas cristalinas mais comuns. Geralmente ocorrem como nódulos e concreções enegrecidas, bem como concentram-se nas glébulas ferruginosas como "coatings", veios e manchas pretas (Taylor \& MacKenzie, 1966).

Trabalhos como de Beauvais \& Colin (1993), Beauvais \& Roquin (1996), Beauvais et al. (1990), Childs (1975), Roquin, (1990), Schwarz (1994) e Sidhu et al. (1977) identificaram vários elementos como componentes de concreções e ferricretes. Afora os trabalhos de Childs (1975) e Sidhu (1977.), o qual especificamente caracterizaram química e mineralogicamente concreções e nódulos de ferro e manganês, todos os outros utilizaram a identificação e o comportamento dos elementos químicos a fim de proporcionar "um melhor entendimento da evolução dos sistemas de intemperismo laterítico" (Beauvais \& Colin, 1993, p. 98). Basicamente os mesmos elementos foram identificados pelos autores. Possibilitando-nos relacionar outros elementos como constituintes dos ferricretes, Beauvais et al. (1990) estudando a evolução geoquímica e degeneração de ferricretes, obtiveram a seguinte relação entre posição geomórfica, características morfológicas e constituintes desses materiais na República Central Africana: a) nas porções mais elevadas da paisagem, ferricretes com estruturas maciças e elevados conteúdos de $\mathrm{Fe}$, hematita e caulinita, são também enriquecidos em elementos 
traços poucos móveis, tais como: $\mathrm{Sr}, \mathrm{La}, \mathrm{V}$ e $\mathrm{Zr}$; b) nas posições intermediárias das paisagens, ferricretes pseudonodulares apresentaram maiores conteúdos de gibbsita, quartzo, bem como maior enriquecimento em elementos químicos de maior mobilidade no solo, tais como $\mathrm{Ba}, \mathrm{Nb}, \mathrm{Ce}, \mathrm{P}, \mathrm{Mn}$, $\mathrm{Co}$ e $\mathrm{Ni}$, os quais são imobilizados nos oxidohidróxidos secundários; c) nos baixos platôs, ferricretes macios com elevado conteúdo de $\mathrm{Si}$, Al e goetita, também apresentam-se enriquecidos em $\mathrm{Mg}, \mathrm{K}, \mathrm{Cr}, \mathrm{Zn}, \mathrm{Cu}$, $\mathrm{Sc}, \mathrm{Y}$, e Yb. Segundo os autores, esses últimos elementos refletem a composição da rocha de origem do ferricrete devido sua natureza menos evoluida.

Ibanga (1980, p. 103-104) avaliando as propriedades fisicas, químicas e mineralógicas de "lateritas" amostradas em diferentes continentes, identificou um baixo conteúdo de magnésio, cálcio, sódio, potássio e manganês nessas amostras. $\mathrm{O}$ autor argumenta que esses resultados "podem ser evidência do longo e intenso processo de intemperismo que tomam lugar antes da formação das lateritas". Assim, "as bases são removidas ou perdidas durante a laterização". Essa natureza residual é hoje amplamente aceita como o principal mecanismo de gênese das "lateritas" (Aleva, 1994 e McFarlane, 1983)

\subsubsection{Composição mineralógica}

A variada composição química dos ferricretes refletem sua diversidade mineralógica. Assim, mais que 170 minerais foram identificados como componentes das "lateritas" e bauxitas, porém somente dez ou onze estão em quantidades significativas e correspondem aos óxidos e hidróxidos de ferro e alumínio, juntamente com minerais secundários estáveis e minerais primários resistentes ao intemperismo (McFarlane, 1983). Dentre esses, hematita, goetita, caulinita, quartzo (Leprun, 1981 e Tardy \& Nahon, 1985) e as vezes gibbsita (Beauvais, et al. 1990; Beauvais \& Colin, 1993; Beauvais \& Roquin, 1996; Tardy 1993; Tardy \& Roquin, 1992 e Roquin et al., 1990b) foram identificados por muitos autores como os principais constituintes dos ferricretes. 
Considerações sobre alguns desses elementos e outros constituintes estão enunciadas a seguir, proporcionando informações complementares em relação a seus comportamentos e mecanismos envolvidos na variabilidade entre fácies de ferricretes.

As relações entre hematita e goetita no desenvolvimento de nódulos e crostas ferruginosas são amplamente estudadas e conhecidas. Ferricretes mais evoluídos e mais velhos, geralmente ocorrem nas porções mais elevadas da paisagem e são mais hematíticos quando comparados aos menos evoluídos. Estes, por sua vez, são menos ferruginosos e mais ricos em goetita (Beauvais \& Roquin, 1996; Beauvais et al., 1990 e Sivarajasingham et al., 1962). Assim, a ferruginização é primeiramente goetítica nos estágios iniciais de desenvolvimento das "lateritas" e torna-se progressivamente hematítica durante processos de oxidação do perfil, originando nódulos ferruginosos que podem evoluir para crostas ferruginosas maciças (Nahon, 1976) e Nahon (1986). Como último processo na evolução dos ferricretes, goetita novamente se desenvolve, agora como um córtex amarelo ou marrom em torno ou ainda dentro dos nódulos hematíticos. Esses nódulos com córtex goetítico podem originar-se ou do desmantelamento da couraça maciça ou da própria evolução dos nódulos hematíticos por processos de hidratação aos quais a superficie dos perfis "lateriticos" está submetida (Ambrosi \& Nahon, 1986; Anand \& Gilkes, 1987b; Beauvais \& Colin, 1993; Beauvais \& Tardy, 1993; Nahon, 1976; Nahon, 1991 e Roquin, 1990). Assim, o fenômeno da hidratação é o mecanismo desencadeador que transforma hematita em goetita nos locais de intimo contato com a solução percolante (Beauvais \& Tardy, 1991), bem como são responsáveis pela formação dos chamados pisolitos de degradação (glébulas com córtex goetítico) freqüentemente distribuídos no topo dos perfis ferricretes (Ambrosi \& Nahon, 1986; Roquin, 1990 e Tardy, 1993).

Caulinita é único mineral silicatado presente em proporções consideráveis dentro das "lateritas" (Alexander \& Cady, 1962) e freqüentemente mostra uma história complexa (Schellmann, 1994) caracterizada por dissoluções e neoformação durante o desenvolvimento dos perfis "lateríticos"(Ambrosi et al., 1986; Muller \& Bocquier, 1986 e Nahon, 1991). Alguns autores consideram que o conteúdo de caulinita mantêm-se 
constante durante esse desenvolvimento (Roquin et al., 1990b), porém McFarlane (1991) afirma que esse mineral desaparece e salienta que o mecanismo responsável pelo desaparecimento da caulinita nas "lateritas" é a questão fundamental para elucidação dos processos de laterização, juntamente com a remoção de quartzo. O desmantelamento das crostas de ferro podem promover a transformação da hematita em goetita como enunciado acima, assim como a transformação de caulinita em gibbsita (Beauvais \& Tardy, 1993; Beauvais et al., 1990 e Tardy, 1993). Segundo Tardy (1993) e Tardy \& Novikoff (1988) é comum a ocorrência de gibbsita bem cristalinizada e de grande tamanho na superficie das couraças ferruginosas.

Quartzo pode estar contido nos ferricretes em proporções variadas. Tanto pode estar ausente como presente em pequenas quantidades, porém rochas com elevado conteúdo do mineral originam materiais "lateríticos" com proporções significativas de quartzo, podendo até destacar-se como seu principal constituinte (Sivarajasingham et al., 1962). O conteúdo de sílica nas "lateritas" freqüentemente está relacionado à presença de quartzo (Alexander \& Cady, 1962 e Sivarajasingham et al., 1962). Assim, Alexander \& Cady (1962) afirmam que o conteúdo de sílica pode ser alto nas "lateritas" se está na forma de quartzo e que algumas "lateritas" são areias cimentadas com relativamente pouco conteúdo de goetita e hematita. Esses grãos de quartzo quando observados em seções delgadas, são os principais constituintes do esqueleto em glébulas ferruginosas (Brewer, 1976) e representam relíquias do material intemperizado incorporado aos seus constituintes (Muller \& Bocquier, 1986). Geralmente encontram-se fortemente intemperizados, originando figuras típicas de dissolução na superficie do mineral (Chauvel et al., 1982; Flageoleet, 1981 e FitzPatrick, 1993). Assim, a dissolução do quartzo origina poros denominados por alguns autores como "cavidades de dissolução" onde o mineral pode estar ainda presente (Muller e Bocquier, 1986; Muller et al., 1981; Nahon, 1976 e Nahon et al., 1977) e as quais podem ser preenchidas por outros materiais que não óxidos de ferro (Leprun, 1981). Dentre esses, Bourman et al. (1987) encontraram gibbsita em feições de dissolução, acrescentando que sua presença é indício de condições extremamente intemperizadas, ambientes ácidos onde a drenagem livre 
pode promover intensa lixiviação de solutos. Também Chauvel et al. (1982) comentam que caulinita podem penetrar nos vazios de corrosão de grãos de quartzo. Schellmann (1994, p.140) considera que enormes dissoluções são encontradas nas "lateritas" e salienta que "provavelmente nenhum mineral primário é estável por longos períodos de laterização."

Minerais primários facilmente intemperizáveis também foram identificados nos ferricretes. Dentre eles, feldspato e micas são indicados por muitos autores como constituintes comum de nódulos e concreções ferruginosas (Beauvais \& Roquin, 1996; Debaveye et al., 1987; Ibanga, 1980; Leprun, 1981; Muller \& Bocquier, 1986; Schwertmann \& Fanning, 1976 e Sidhu et al., 1977). Também plagiocásios, hornblenda e epidoto podem estar presentes, sendo interpretado por Leprun (1981, p.152) como litorrelíquias no interior de carapaças e crostas ferruginosas. $\mathrm{O}$ autor considera que a ocorrência dessas litorrelíquias e minerais primários facilmente intemperizáveis "é um forte argumento para propor que o ferricrete desenvolveu in situ a partir do material lítico e portanto, são autóctones." Alexander \& Cady (1962) interpretaram a presença dos minerais primários nos pisolitos como um processo de isolamento ou encapsulamento desses minerais em locais protegidos do intemperismo. Segundo McFarlane (1976, p.35) "pisolitos encerram e efetivamente fossilizam os materiais dos quais eles se formam". Assim, uma película de ferro circundando os grãos de feldspato garantiria a permanência ou mesmo sua existência no interior das glébulas. Similar interpretação pode ser encontrada nos trabalhos de McFarlane (1983) e Debaveye et al. (1987). Esses últimos autores acrescentam que o desmantelamento desses nódulos e concreções pode contribuir para o rejuvenescimento dos solos. 


\subsubsection{Morfologia}

'Lateritas ocorrem em várias formas morfológicas. As mais comuns são concreções discretas" (McFarlane, 1976, p.66).

A diversidade morfológica entre fácies de ferricretes fez com que muitos termos fossem criados e definidos. Esse fato é verificado tanto macro como micromorfologicamente como pode-se observar nas classificações abaixo relacionadas, as quais correspondem as mais recentes interpretações de diferentes autores.

Tardy (1993) propõe a seguinte classificação morfológica para materiais ferruginosos endurecidos, baseado em princípios genéticos:

1. Couraças ou carapaças maciças. Segundo o autor, o fundo matricial deste tipo de couraça não apresenta orientação, portanto o plasma argiloferruginoso é isotrópico. Esse tipo resulta da coalescência de nódulos ferruginosos que se confundem e fundem no plasma ferruginoso envolvente. Essas fácies se desenvolvem principalmente sobre granitos, migmatitos e xistos, porém em anfibolitos e rochas básicas seu desenvolvimento é menos sistemático.

\section{Couraças nodulares de agradação e couraças pisolíticas de degradação.} Couraças nodulares em estágio inicial de formação originam os chamados nódulos de agradação, ou seja, não apresentam córtex. Se a couraça está se desmantelando, ocorrem os pisolitos de degradação, caracterizados pela presença de córtex. Essas então denominam couraças pisolíticas de degradação

Bourman (1993) estudando a gênese de ferricretes no sul da Austrália, propôs a seguinte classificação para os diferentes tipos encontrados:

1. Rocha ferricretizada: compreende rocha endurecida por ferro na qual estruturas da rocha de origem do ferricrete são preservadas.

2. Sedimentos ferricretizados: consistem de sedimentos que foram impregnados e endurecidos por óxidos de ferro, os quais podem ser de três tipos, conforme sua constituição: 

a) sedimentos clásticos ferricretizados
b) sedimentos orgânicos ferricretizados
c) xisto ferricretizado

3. Ferricretes complexos e compostos: esses tem origem e estruturas complexas originários de diferentes materiais de origem. Eles incluem:

a) ferricrete pisolítico: consistem de pisolitos individuais. A maioria deles com bordas múltiplas e podem estar cimentados formando uma massa coerente assemelhandose a rocha;

b) ferricrete nodular: são semelhantes ao ferricrete pisolítico exceto no tamanho e córtex. Esses são maiores e geralmente não apresentam córtex;

c) ferricrete "slabby": consiste de estruturas planas dispostas horizontalmente. Podem atingir muitos centímetros de espessura e geralmente são separados por uma matriz argilosa;

d) ferricrete vermiforme: apresentam canais sinuosos assemelhando-se aos produzidos por minhoca, os quais são freqüentemente preenchidos com argila de constituição totalmente diversa da matriz envolvente;

Outras estruturas morfológicas podem ser encontradas em trabalhos recentes. Designações como ferricretes conglomeráticos e vesiculares são citados por Thomas (1994) como componentes de ferricretes maciços, originários da coalescência de pisolitos ou nódulos irregulares. Algumas adjetivações geralmente advém das classificações utilizadas por McFarlane (1976) para identificar diferentes fácies de "lateritas", tais como lateritas vesiculares, conglomeráticas, vermiformes, celulares. Essas caracterizam feições morfológicas específicas, sendo que algumas classificações atuais utilizam essa nomenclatura para se referir a fácies semelhantes, porém utilizando como adjetivação do termo ferricrete, embora Ibanga (1980) considere que as diferenças entre as diferentes "lateritas" nunca foram claramente definidas.

As variadas condições ambientais e os processos envolvidos na gênese dos ferricretes são responsáveis por sua diversidade e desenvolvimento de diferentes perfis de 
intemperismo. Os itens seguintes tratam desses assuntos, fornecendo subsídios para interpretações futuras e elucidação dos mecanismos envolvidos na gênese de ferricretes na área estudada.

\subsection{O perfil ferricrete}

"Laterita" é freqüentemente discutida sem referência a parte principal de seu ambiente: o perfil na qual ela ocorre. Quando isso é considerado, é possivel eliminar algumas especulações concernentes à sua gênese (McFarlane, 1976).

A identificação dos horizontes e camadas associados ao horizonte ferricrete nos perfis de intemperismo, geralmente são referidos e comparados na literatura com "perfil laterítico típico". Um perfil típico é um modelo ou uma abstração desenvolvida pelos cientistas para ilustrar as características essenciais de uma multitude de perfis sob estudo (Aleva, 1994). Para as "lateritas", o perfil típico é dito compreender os seguintes horizontes e camadas, considerando-os da base para o topo do perfil: rocha ou saprolito não lixiviado, recobertos pelo horizonte mosqueado e zona pálida, e acima deles encontra-se a "laterita" (McFarlane, 1976 e 1986) ou horizonte ferricrete. Zona pálida é por definição descolorida devido a lixiviação do ferro (McFarlane, 1976) e a zona mosqueada é caracterizada pelo contraste entre os domínios esbranquiçados e as manchas de ferro (Tardy, 1992), na qual ocorre uma incompleta precipitação dos óxidos (McFarlane, 1976). No entanto, tais perfis são amplamente excedidos em número pelos perfis atípicos, como consideram Aleva (1994) e McFarlane (1986). A ausência de determinados horizontes ou mesmo sua variação em espessura, fatores que caracterizam esses perfis atípicos, estão relacionados aos modos de gênese dos perfis ferricretes. Nas "lateritas" de baixo nível por exemplo, formadas pela oscilação do lençol, a zona pálida não tem sido encontrada (McFarlane, 1976 e McFarlane, 1983).

Outras denominações são atualmente preferidas, como proposto por Tardy \& Nahon (1985). Segundo os autores, um perfil ferricrete é constituído de 5 zonas superpostas, que da base para o topo compreendem: rocha, saprolito grosseiro, saprolito fino ou litomarga, camada argilosa mosqueada e horizonte ferricrete. Tardy (1992) 
considera que alguns termos freqüentemente empregados na literatura, tais como saprolito, litomarga, zona pálida e argilas variegadas referem-se a mesma coisa. Porém, desaconselha a utilização dos termos argilas variegadas e zona pálida, devido a confusão em torno de suas definições.

Bocquier et al. $(1984)^{2}$, citados por Tardy (1992), distingue três zonas ou principais horizontes nos perfis "lateríticos" típicos, abrangendo genericamente todos os horizontes citados acima:

(a) zona de alteração. Situada na base do perfil e inclui os diferentes tipos de saprolito (saprolito grosseiro e saprolito fino ou litomarga);

(b) zona glebular, localizada na parte intermediária. Corresponde ao horizonte ferricrete; e

(c) zona macia, não endurecida e localizada na parte superior do perfil. São os solos acima do horizonte ferricrete. Nas áreas tropicais, um grande número de solos glebulares são cobertos por esse horizonte, cuja origem é diversa e sujeita a diferentes interpretações (Tardy, 1992). Nessas áreas, a zona macia é caracterizado por uma acumulação relativa de minerais primários, tais como quartzo, e minerais secundários, como caulinita e goetita e geralmente são considerados como produtos do desmantelamento in situ das couraças ferruginosas (Alexander \& Cady, 1962; Beauvais \& Tardy, 1991; Chauvel et al., 1982; Ladeira, 1995; Nahon, 1976 e Nahon et al., 1989). No entanto, para Ollier $(1991$, p.166) esses solos acima dos horizontes ferricrete foram "formados como parte do perfis de intemperismo", uma vez que não poderiam ser originários do ferricrete abaixo, o qual é constituído unicamente de óxidos e hidróxidos de ferro. $O$ autor acrescenta que em muitos perfis, o solo foi removido devido aos processos erosivos e não está mais presente acima do ferricrete. Ainda Tardy (1992, p. 391) comenta a existência de um solo arenoso na superficie das couraças, freqüentemente misturado aos pisolitos de degradação. Esse horizonte é considerado um componente do "metabolismo do ferricrete e uma fase essencial na sua reconstituição". Portanto, as diferentes interpretações envolvidas na gênese desses solos e ferricretes corroboram a importância do presente estudo, contribuindo para a elucidação dos mecanismos

\footnotetext{
${ }^{2}$ BOUQUIER, G; MULLER, J.P.; BOULANGÉ, B. 1984. Les latérites. Connaissances et perspectives actuelles sur les mécanismes deleur différenciation. Livre Jubilarie du Cinquantenaire de l'AFES, Paris, pp. 123-138.
} 
envolvidos e caracterização do perfis ferricrete desenvolvidos sobre a formação Adamantina no Estado de São Paulo.

\subsection{Condições ambientais de formação}

A distribuição de diferentes fácies de ferricrete tem sido correlacionado com diferenças climáticas por muitos autores. Tardy et al. (1991) observando as diferenças mineralógicas entre os ferricretes do Brasil, África, Índia e Austrália relatam que a distribuição geográfica e composição mineralógica desses materiais são controladas não somente pelas diferenças climáticas reinantes nos dias atuais, mas sim e acima de tudo pelas sucessões paleoclimáticas durante 150 milhões de anos, desde a deriva dos continentes. Os autores consideram que os ferricretes são encontrados e se desenvolvem principalmente em zonas tropicais úmidas, caracterizadas por uma precipitação média anual limitando entre 1200 a $1700 \mathrm{~mm}$, com quatro meses de estação seca, umidade relativa inferior a $80 \%$ e temperatura média anual em torno de $28^{\circ} \mathrm{C}$. Assim, "ferricretes são típicos de climas tropicais quentes e úmidos, mas com longa estação seca", onde o endurecimento do material ferruginoso pode ocorrer e formas nodulares ou pisoliticas se desenvolvem. (Tardy et al., 1991, p. 291). No entanto, para Bourman et al. (1987), McFarlane (1976), e Wright et al. (1992) essas condições só são exigidas quando o ferricrete possuir uma origem essencialmente pedológica ou residual. McFarlane (1976) considera que o clima do solo ou pedoclima não necessariamente reflete o clima atmosférico. A autora sugere que a oscilação do lençol freático proporciona condições alternantes de umidecimento e secagem tanto em climas permanentemente úmidos ou sazonalmente úmidos, como em regimes secos. Assim, ferricrete de lençol pode se formar sob um amplo limite de climas uma vez que "a natureza sazonal do clima atmosférico é exagerado ao nível do solo" (McFarlane, 1976, p.43). Existem alguns exemplos que corroboram essas assertivas. Wright et al. (1992) destacam que ferricretes de lençol estão se desenvolvendo atualmente nas margens de lagos hipersalinos em Vitória na Austrália, sob condições áridas. Também Bourman et al. (1987, p.21) argumentando sob a formação de ferricretes originários da oscilação do lençol, relatam que "há uma clara 
evidência da mobilização e deposição de ferro nos atuais ambientes de intemperismo sob condições climáticas do tipo mediterrâneo," os quais estão associados à elevada salinidade. Os autores atribuem essa deposição do ferro à precipitação de ferridrita a partir de soluções enriquecidas em ferro ferroso $\left(\mathrm{Fe}^{2+}\right)$ quando $\mathrm{pH}$ e Eh atingem valores apropriados. Ollier (1991, p.168) enfatiza que em muitas situações atuais ferricretes podem estar se formando no terço inferior das vertentes onde o lençol freático é descarregado e o ferro em solução pode precipitar. $O$ autor acrescenta que essa "precipitação é mais significativa onde há uma mudança abrupta da permeabilidade, ou seja, entre um saprolito relativamente denso e um solo ou sedimento relativamente mais permeável."

Pelo enunciado acima observa-se que há basicamente dois ambientes de formação de ferricretes que por sua vez caracterizam tipos diferenciados desses materiais ferruginosos. As chamadas "lateritas" de lençol são resultantes da segregação do ferro nos sopés das vertentes em um estreito limite de oscilação do lençol freático e as "lateritas" pedogenéticas, "formadas no perfil de vadosa", onde o "lençol freático parece não desenvolver um papel significativo" (McFarlane, 1983, p. 24). Ferricretes pedogenéticos estão normalmente associados aos solos ou perfis de intemperismo espessos, enquanto os de lençol, apresentam pouco ou nenhum desenvolvimento dos perfis (Wright et al., 1992). Vários autores tem referido a esses diferentes tipos como "lateritas de terras baixas e altas" respectivamente (Hamilton, 1964 e Trendall, 1962). A origem dessas adjetivações ao termo "laterita" é encontrada no trabalho de McFarlane (1976) e recentemente Bourman et al. (1987) e Wright et al. (1992) utilizaram para se referir aos ferricretes. Assim, McFarlane (1976) distingue três tipos de "lateritas", a saber: fase contínua, pedogenética e laterita de lençol, sendo que as duas últimas são compostas basicamente de pisolitos. Esses termos originalmente derivaram de supostos processos genéticos ativos durante o desenvolvimento dos perfis "lateríticos" (Aleva, 1994).

Extensas discussões foram centradas na origem de ferricretes e "lateritas" de lençol e pedogenético, algumas das quais podem ser encontradas nos trabalhos de 
Hamilton (1964), McFarlane (1976 e 1983), Goldbery \& Beyth (1984), Bourman et al. (1987) e Wright (1992). Hamilton (1964, p.269) considera que a "gênese de ambos os tipos "lateritas" é bastante diferente" e que a composição química não é um fator que possibilita discriminá-los (Hamilton, 1964 e McFarlane, 1976). No entanto, Wright et al. (1992), baseando-se na literatura, compila uma série de argumentos mineralógicos, morfológicos e de estágios de desenvolvimento dos perfis ferricretes, possibilitando estabelecer diferenças e identificar as origens entre ferricretes pedogenéticos e de lençol.

Muitos autores atribuem ao fenômeno de inversão do relevo como o mecanismo responsável pelo aparecimento de "lateritas" nas posições elevadas da paisagem, ou seja, "lateritas" de terras altas (Ollier, 1991; McFarlane, 1976; Maignien, 1966 e Schwarz, 1994) e Ollier (1991, p. 171) até mesmo sugere que "ferricretes nunca cobriram paisagens inteiras, mas foram somente confinados aos vales ou terço inferior das vertentes e agora estão expostos nas bordas dos platôs pela inversão do relevo". Assim, o autor propõe que todos os ferricretes são exclusivamente originários nos sopés de vertente, proveniente do movimento lateral de ferro reduzido.

Alexander \& Cady (1962) destacam que são necessárias três condições básicas que antecedem a segregação e acumulação de óxidos de ferro na formação das "lateritas":

1. suprimento adequado de ferro. Segundo o autor, o suprimento desse elemento pode estar na própria rocha subjacente se possuir quantidades significativas de ferro ou vir de outro ponto do perfil ou paisagem. Assim a acumulação de ferro pode se dar tanto de forma relativa como absoluta. No primeiro caso, o enriquecimento do ferro ocorre devido à remoção dos outros constituintes e acumulação de elementos poucos móveis e resistentes ao intemperismo, originando as chamadas "lateritas residuais" amplamente discutida e defendida por McFarlane (1976, p.97) como o principal mecanismo envolvido na formação das "lateritas" localizadas nos interflúvios. Essa origem residual é bem aceita nos dias atuais (Aleva, 1994 e McFarlane, 1983), no entanto, "lateritas nas posições de sopé de vertente usualmente possuem muito de sua concentração provenientes da acumulação absoluta" de ferro (McFarlane, 1983, p.21). 
Alexander \& Cady (1962) referindo-se ao suprimento adequado de ferro à gênese das "lateritas" acrescentam que a quantidade do elemento necessária para promover a cimentação é função da textura do material que está sendo cimentado. Se o material for arenoso, será necessário menor quantidade do agente cimentante em função da sua pequena superficie especifica quando comparado a materiais mais argilosos.

2. Alternância de estações secas e úmidas. Os autores consideram que as condições ideais para a formação dos ferricretes são estações secas e úmidas de comprimentos iguais. Acrescentam que caso a estação seca não se prolongue em igual período à estação úmida haverá redução na segregação dos óxidos de ferro. Ao contrário, Bardossy (1981) relata que 1 ou 2 meses de estação seca são suficientes para o desenvolvimento das lateritas. Como comentado anteriormente, McFarlane (1976, p.45) salienta que "condições alternantes podem estar ocorrendo a nível de lençol em todos os regimes climáticos, e por esta razão é importante distinguir entre laterita pedogenética e de lençol freático". Portanto, torna-se evidente que os diferentes argumentos e divergências em relação às condições adequadas de sazonalidade à gênese desses materiais são condicionados pelos próprios mecanismos envolvidos na evolução genética dos ferricretes estudados. Certamente, ciclos repetidos de umidecimento e secagem encorajam a oxidação dos compostos de ferro e a formação de goetita e hematita cristalinas (McFarlane, 1976 e Thomas, 1994).

3. relativa planura da superfície. Essa terceira exigência está relacionada à manutenção das condições hidrológicas do perfil necessárias à segregação e acumulação do ferro. Segundo os autores, a zona de segregação deve submeter-se periodicamente a condições de saturação e essa condição só será satisfeita em áreas planas, associadas a solos pouco permeáveis, ou ainda a uma elevada oscilação do lençol freático. No entanto, Ollier (1991, p.172) enfatiza que ferricretes podem "ter um considerável declive inicial". $\mathrm{O}$ autor sugere que esses materiais podem ser formados nos vales através do movimento lateral do ferro em solução, derivados de grandes áreas lixiviadas. Tal mecanismo, associado à concentração e precipitação do elemento na zona de oscilação do lençol freático, possibilitaria o desenvolvimento dos ferricretes em condições de relevo 
acentuado. Aleva (1994) também considera a necessidade de um mínimo de inclinação para o desenvolvimento das "lateritas", tida pelo autor como de origem essencialmente residual. Acrescenta que condições de uma relativa planura da superficie favoreceria uma maior taxa de percolação da água, necessárias a remoção de solutos e reposição de água fresca em contato com a matéria mineral ainda não lixiviada.

Analisando as diferentes interpretações, torna-se evidente a associação do relevo com os mecanismos envolvidos na gênese de ferricretes: natureza residual requer relevos planos, enquanto aportes externos de ferro e desenvolvimento no limite de oscilação do lençol possibilitam relevos mais acidentados na gênese desses materiais. No entanto, Thomas (1994) considera errôneo a interpretação de que a planura da superficie é causa do desenvolvimento dos ferricretes. Enfatiza que estudos recentes tem reconhecido que o baixo declive dos extensos planos "laterizados" podem ser resultado e não causa da presença desses materiais, os quais impõem uma certa planura as paisagens a medida que essa é rebaixada e as crostas de ferro vão espessando e tornando-se contínuas.

Bardossy (1981, p.288) comentando sobre as condições ambientais para a formação de "laterita" salienta que esses materiais "podem se formar de praticamente todo tipo de rocha desde que condições climáticas e outras condições ambientais sejam favoráveis". McFarlane (1976) argumenta que a presença de argilominerais 2:1 é uma condição desfavorável, até mesmo inibindo a formação das "lateritas" uma vez que o ferro será retido na estrutura desses minerais, tornando-se indisponível para remoção e precipitação. No entanto, no trabalho de Anjos et al. (1995) é documentado materiais plínticos e nodulares associados a solos de atividade alta ( $\mathrm{Ta}$ ), fato que possibilita diferentes interpretações genéticas dependendo da condições locais.

McFarlane (1983) considera que há um desacordo generalizado quando o assunto é o tipo de vegetação adequada para a formação das "lateritas". No entanto, vários trabalhos tem enfatizado sua degradação sob floresta tropical úmida (Alexander \& Cady, 1962, Beauvais \& Colin, 1993, Beauvais \& Tardy, 1993 e Sivarajasingham et al., 1962) devido ao aumento nos processos de hidratação, a um decréscimo no Eh e lixiviação do ferro. 'Tm tais ambientes o desmantelamento da crosta ferruginosa resulta diretamente da 
umidade, decomposição da matéria orgânica e respiração das raizes", os quais proporcionam hidratação, redução e também levam à transformação da hematita em goetita, da caulinita em gibbsita, bem como são responsáveis pela lixiviação preferencial do ferro em relação ao alumínio. Porém, sob tais condições climáticas, em floresta tropical úmida, os ferricretes podem tanto estar se formando como degradando, conforme Beauvais \& Tardy (1993, p.279). Segundo os autores, nessas áreas os platôs mais elevados tendem a desaparecer, enquanto as partes mais baixas das vertentes são enriquecidas pela acumulação do ferro, provindo dos locais de desmantelamento localizados acima e assim, regenerando as couraças.

Condições edafoclimáticas adequadas a gênese dos ferricretes definem os locais da paisagem onde esses materiais ferruginosos desenvolvem, seu estágio de formação ou de degradação. Essas condições explicam porque vertentes muito próximas e opostas entre si comportam-se diferentemente em relação à presença e estágio de evolução dos ferricretes, podendo até mesmo existir na forma de espessas coberturas ferruginosas pisolíticas em um lado do córrego e estar completamente ausente noutro.

\subsection{A origem do ferro nos ferricretes}

Debates sobre materiais ferruginosos endurecidos tem freqüentemente centrado nas fontes e processos de enriquecimento de ferro, os quais levam à formação de ferricretes. Essas questões assumem a compreensão de fenômenos relacionados a mobilidade do ferro, aos movimentos vertical e lateral do lençol freático contendo ferro reduzido ou ainda a formação de complexos organo-metálicos, bem como ao controle da paisagem e do relevo em tais movimentos (Thomas, 1994). Nos itens a seguir, serão abordados alguns desses assuntos de maior interesse para o presente trabalho, enfatizando a origem e os processos envolvidos na acumulação do ferro na gênese dos ferricretes.

Thomas (1994) salienta que basicamente três mecanismos são amplamente debatidos como responsáveis pelo fornecimento de ferro à formação dos ferricretes: 
(1) transporte vertical onde o $\mathrm{Fe}^{2+}$ movimenta-se a dezenas de metros, seja pelo movimento gravitacional descendente associado ao rebaixamento do lençol freático, seja pelo movimento ascendente do elemento através do mecanismo de difusão. O movimento descendente de ferro, promovendo grandes acumulações nas "lateritas" não pode ser inteiramente originado do solo acima. No entanto, para algumas lateritas pedogenéticas localizadas nos interflúvios, parece claro que essa seja a única fonte imediata de enriquecimento (McFarlane, 1976). Assim, como salientam McFarlane (1976) e Thomas (1974), torna-se necessário evocar um enriquecimento contínuo do elemento nesses solos;

(2) transferência lateral do elemento através de um fluxo convergente para sítios de recepção, tais como fundo dos vales e depressões;

(3) retenção e acumulação nos horizontes superficiais na forma de pisolitos e nódulos quando o perfil é rebaixado pelo intemperismo.

Assim, como comentam Sivarajasingham et al. (1962), a origem do ferro na gênese das "lateritas" podem ser debatidas sob diferentes aspectos. Aqueles onde as fontes de ferro são externas, envolvendo tanto o enriquecimento por movimento descendente em solução, como por ação capilar, ou ainda pelo movimento lateral do $\mathrm{Fe}^{2+}$ em solução provindo das áreas mais elevadas da paisagem e finalmente, o enriquecimento pela flutuação do lençol freático. Esse último "é a hipótese mais amplamente aceita de enriquecimento de ferro de fontes externas" (Sivarajasingham et al., 1962, p.47). Os autores também consideram o desenvolvimento das "lateritas" em locais sem o enriquecimento de fontes externas, originando as chamadas lateritas residuais. Atualmente "parece pouco duvidoso que lateritas são essencialmente acumulações residuais de materiais quimicamente resistentes" (McFarlane, 1983, p. 22), no entanto "muitas são claramente afetadas em maior grau pelo enriquecimento de fontes externas" (Sivarajasingham et al., 1962, p.45). Indubitavelmente, a formação de ferricretes e materiais relacionados por mecanismo de deposição local de ferro no estreito limite de oscilação do lençol é amplamente defendido por muitos autores, como pode ser observado nos trabalhos recentes de Anjos et al. (1995), Bigarella et al. (1996), Bourman 
(1993), Bourman et al. (1987), Goldbery \& Beyth (1984), King et al. (1990), Pedro \& Melfi (1982) e Wright et al. (1992), embora o influxo lateral do elemento em solução esteja intimamente associado (Bigarella, et al., 1996). Este é responsável pelo constante suprimento de $\mathrm{Fe}^{2+}$ às porções inferiores da paisagem (Maignien, 1966), descarregando no lençol freático e precipitando o $\mathrm{Fe}^{3+}$ em sua superficie, dando origem à maioria dos ferricretes e "lateritas" localizados nessas porções relativamente baixas da paisagem (Bigarella et al., 1996; Bourman, 1993; Bourman et al. 1987 e McFarlane, 1983). Assim, qualquer que seja a fonte, o ferro parece ser mais comumente depositado na porção superior do lençol freático, onde se tem lugar a oxidação dos compostos ferrosos em férricos (Bigarella, et al., 1996).

Um trabalho relativamente recente tem enfatizado como o movimento vertical do ferro em solução desenvolve um importante papel na formação de ferricretes. Mann \& Ollier (1985) debatendo sobre esse assunto, sugerem que a constante associação entre ferricretes e zonas pálidas envolvem mecanismos de difusão química na gênese desses materiais. Segundo os autores, a zona pálida desenvolve concomitantemente ao ferricrete, fornecendo $\mathrm{Fe}^{2+}$ por difusão química e precipitando na forma de $\mathrm{Fe}^{3+}$ quando o elemento alcança uma zona de oxidação na superficie do lençol. "No entanto, o movimento ascendente do $\mathrm{Fe}^{2+}$ como resultado da difusão iônica ainda permanece especulativo" (Thomas, 1994, p. 99) e como enfatiza Ollier (1991, p.171): "conceitos que são baseados no simples processo vertical e ignora o movimento lateral do ferro que é quantitativamente mais importante, são improváveis ter sucesso na explicação da gênese dos ferricretes e sua relação com a evolução da paisagem". Essas assertivas divergem do movimento ascendente do ferro como a principal fonte do elemento na gênese de ferricretes, fato também enfatizado em outros trabalhos, como demonstrado abaixo.

A relação entre zona pálida e formação de "laterita" é amplamente discutida por McFarlane (1976 e 1983). A autora considera que a coexistência entre ambos os horizontes nos perfis de intemperismo “é o maior responsável pela evidência circunstancial que fomenta a teoria de formação de laterita como um precipitado" (McFarlane, 1976, p. 57). Segundo essa teoria, a acumulação do ferro na "laterita" é 
originária da zona pálida, precipitando quando o elemento alcança condições oxidantes próximo à superficie do lençol. No entanto, proporciona um excelente sumário das razões para a rejeição de uma possível origem das lateritas por precipitação. Dentre as principais objeções podemos destacar:

a) onde zonas pálidas e lateritas coexistem, não há uma consistente relação direta entre grau de desenvolvimento da zona pálida e laterita;

b) há numerosas ocorrências de lateritas formadas in situ diretamente sobre a rocha;

Vários trabalhos tem sugerido que a origem do ferro na formação de ferricretes e "lateritas" pode ser proveniente do desmantelamento de velhas couraças. O ferro dissolvido durante esse processo, move-se tanto lateral, depositando nas porções inferiores da paisagem, como verticalmente, originando materiais ferruginosos jovens e macios, abaixo de couraças mais evoluídas e hematíticas (Alexander \& Cady, 1962; Ambrosi \& Nahon, 1986; Beauvais et al., 1990; Beauvais \& Tardy, 1991; Beauvais \& Tardy, 1993; Fölster et al., 1971; King et al., 1990; Maignien, 1966; McFarlane, 1976; Sivarajasingham et al., 1962; Tardy, 1992; Tardy \& Nahon, 1985 e Tardy et al., 1988).

A mobilidade do ferro, sua concentração e segregação originando extensas coberturas com ferricretes estão intimamente associados ao comportamento do elemento nos pedoambientes. Sua imobilização nas regiões tropicais se dá principalmente nas formas de goetita e hematita, minerais de baixa solubilidade em condições normais de $\mathrm{pH}$ e Eh dominantes na maioria dos solos oxidados. No entanto, a dissolução desses óxidos de $\mathrm{Fe}^{3+}$ é possível em ambientes redutores, onde e quando o $\mathrm{O}_{2}$ torna-se deficiente devido a atividade microbiana. O ferro divalente formado pode ser oxidado in situ ou pode ser transportado a grandes distâncias e reoxidado sob um novo ambiente. Assim, o elemento pode submeter-se a variáveis períodos de imobilização e mobilização dependendo dos valores de $\mathrm{pH}$ e Eh prevalecentes nos pedoambientes. Esses processos condicionam padrões diferenciados de distribuição espacial do ferro em diferentes escalas, seja dentro de um agregado, um horizonte ou ainda dentro de um perfil de solo ou mesmo a nível de paisagem (Schwertmann \& Taylor, 1989), e são responsáveis pela formação de ferricretes 
e materiais relacionados, distribuidos em grandes extensões nas paisagens tropicais. Associado à mobilidade do ferro nos solos, sua concentração e precipitação na forma de mosqueados, nódulos e concreções constituem os processos básicos na elucidação dos mecanismos envolvidos na gênese dos ferricretes.

\subsection{Gênese dos ferricretes}

Mecanismos de desenvolvimento de "lateritas", ferricretes, nódulos e concreções tem sido estudado e interpretado por vários autores. Dentre eles destacam-se: Ambrosi et al. (1986), Beauvais \& Tardy (1991), Bellinfante et al. (1970), Bocquier et al. (1982), Chauvel et al. (1982), Drosdoff \& Nikiforoff (1940), Muller \& Bocquier (1986), Nahon (1976), Nahon (1986), Nahon (1991) e Tardy e Nahon (1985).

Nahon (1986) definiu detalhadamente estágios de decomposição da rocha e formação de uma nova matriz pedológica como processos evolutivos na gênese dos ferricretes. Para o autor, esse termo caracteriza materiais essencialmente pedogenéticos, ou seja, de natureza residual, formados sob condições tropicais úmidas com estações contrastantes. Como etapa inicial, salienta o autor, é possível reconhecer a substituição pseudomórfica dos minerais da rocha por uma assembléia ferruginosa. Esse processo é principalmente importante quando a rocha é rica em minerais primários ferruginosos (Nahon, 1986), embora o elemento esteja presente em quase todos os tipos de rochas (Thomas, 1994). Associado à formação de manchas ferruginosas, foram observadas as seguintes mudanças a medida que se aproxima da superficie do perfil:

1) corrosão, fissuração e deslocamento do quartzo quando a rocha é reorganizada em uma matriz argilosa;

2) diminuição dos cristais de caulinita com o aumento da substituição do $\mathrm{Fe}^{3+}$ nas folhas octaedrais;

3) aumento da adsorção e segregação de hidróxidos de $\mathrm{Fe}_{2} \mathrm{O}_{3}$ com o aumento do mosqueamento e posterior aparecimento de grandes segregações.

Esses processos levam a formação do que se tem reconhecido na literatura como "camada argilosa mosqueada" ou "horizonte mosqueado", a qual evolui para formar 
ferricretes após repetidos incrementos de $\mathrm{Fe}_{2} \mathrm{O}_{3}$ (Ambrosi \& Nahon, 1986; McFarlane, 1976; Nahon, 1986; Nahon, 1991; Tardy \& Nahon, 1985 e Thomas, 1994). A transferência do ferro se dá pela redução local do $\mathrm{Fe}^{3+}$ que move em solução como $\mathrm{Fe}^{2+}$, gradualmente removendo-o do saprolito circundante, o qual torna esbranquiçado e sujeito a perdas de caulinita por lixiviação e dispersão. O progresso do intemperismo é petrograficamente expresso por um aumento da porosidade, inicialmente como microporos nos primeiros estágios e posteriormente, uma extensa trama de macroporos se desenvolve. Esses podem tornar-se sítios de preenchimento, principalmente de caulinita secundária a qual pode endurecer devido à influxos de $\mathrm{Fe}^{2+}$ oriundos das zonas vizinhas que sofreram depleção do elemento. Quartzo fino, é apontado por Nahon (1976) e Nahon (1986) como outro material comum de preenchimento dos macroporos, movendo-se juntamente com a caulinita. A oxidação e segregação do ferro se dá inicialmente na forma de materiais pouco cristalinos que posteriormente evoluem para nódulos duros e bem cristalinizados.

Vários trabalhos tem enfatizado mecanismos de evolução pedogenéticos como responsáveis pelo desenvolvimento de uma macroporosidade no saprolito e seu posterior preenchimento, caracterizando os processos iniciais na formação de nódulos e concreções ferruginosas. Bellinfante et al. (1970, p. 482) sugerem que a "concreção começa a se formar em uma fenda onde acumula plasma iluvial orientado". Ali se produzem fenômenos de óxido-redução devido à variações estacionais de água no solo. Esses fenômenos provocam a precipitação dos óxidos de ferro e manganês, os quais são adsorvidos pelo plasma argiloso, formando um conjunto compacto associado aos grãos de quartzo, seja devido à desidratação, seja pela cristalinização desses óxidos durante o período seco. A concreção aumenta de tamanho em etapas sucessivas até o sistema não mais constituir um sistema óxido-redutor, terminando o que o autor denominou de "período de crescimento". Outros autores tem verificado a associação de plasma iluviado com materiais ferruginosos. Chauvel (1979) observa que ferriargilans estão freqüentemente associados às superficies das glébulas. $O$ autor sugere que a alimentação e crescimento dessas glébulas é atribuído à vinda de óxidos de ferro transportados 
juntamente com argila, depositando sob a forma de cutãs. Posteriormente ocorre a segregação seguida de uma dissociação entre a caulinita, localizada na parte externa em contato com o vazio, e o ferro, em contato com as glébulas. O processo final é a imobilização dos cutãs, agora predominantemente férricos, na proximidade das glébulas, promovendo seu crescimento. Considerações sobre transferência de soluções na forma de cutãs e acumulações por lessivagem no desenvolvimento e formação perfis "lateríticos" são discutidas por Bocquier et al. (1982).

Tardy \& Nahon (1985) estudando os mecanismos envolvidos na formação de concreções, sugerem que duas grandes pedoturbações afetam a formação de mosqueados. Primeiro, o saprolito é invadido por uma trama de canais e poros tubulares de diâmetro centimétrico, nos quais tanto caulinita detrital como neoformada podem acumular. Posteriormente ferro é mobilizado, proveniente da lixiviação das áreas localizadas em torno de outros poros de grande tamanho (milimétricos) e concentram nas áreas ricas em argila, dando origem aos mosqueados que são os precursores das concreções. Progressivamente, a caulinita secundária acumulada nos poros tubulares de grande tamanho é enriquecida em ferro, onde precipita na forma de hematita. Segundo os autores, a precipitação desse mineral se dá nos poros de menor tamanho $(<<0,1 \mathrm{~mm})$ devido tanto a presença de soluções supersaturadas de ferro, como a baixa atividade da água nesses poros. Assim, "um dos mais remarcáveis fatos no processo de formação dos ferricretes é que o ferro é lixiviado dos poros de grande tamanho e acumula nos poros de pequeno tamanho, isto é, move da areia para a argila" (Tardy \& Nahon, 1985, p. 880). A precipitação do elemento se dá inicialmente na forma de goetita, quando a atividade da água é elevada nos poros de maior tamanho e saturados em ferro. Nessas condições, próximo ao nível do lençol freático, mosqueado é formado e portanto constituído principalmente de goetita. A medida que aproxima-se da superficie do perfil, onde condições oxidantes prevalecem, goetita dá lugar a hematita, precipitando nos poros de menor tamanho onde a atividade da água é baixa, dando origem a concreções endurecidas. Assim, no horizonte mosqueado argiloso, o qual não se encontra permanentemente úmido, a distribuição da porosidade desenvolve um importante papel 
na distribuição desses minerais de ferro e "quando mosqueado evolui para concreção, hematita substitui goetita". (Tardy \& Nahon, 1985, p. 872). Interpretações similares podem ser observadas no trabalho de Ambrosi \& Nahon (1986), no entanto, consideram um enriquecimento absoluto de ferro na gênese do horizonte argiloso mosqueado. Segundo os autores, essa acumulação absoluta origina-se ou da destruição química da superficie de velhos ferricretes ou da perda de ferro dos perfis de intemperismo situados na porção superior da vertente.

Uma relação geral entre a precipitação da hematita como nódulos e concreções e a destruição de caulinita tem sido documentado por vários autores, embora diferentes mecanismos estejam envolvidos (Ambrosi \& Nahon, 1986; Ambrosi et al., 1986; Muller \& Bocquier, 1986; Nahon, 1976; Nahon et al., 1977 e Tardy \& Nahon, 1985). O máximo de formação desses materiais é alcançado nos nódulos e concreções de coloração avermelhada, dominantemente hematíticos, onde a caulinita é quase totalmente dissolvida (Ambrosi \& Nahon, 1986). Isso ocorre devido a liberação de prótons durante a precipitação dos óxidos de ferro a partir de soluções enriquecidas no elemento. Esses prótons atuam como agentes corrosivos dissolvendo os cristais de caulinita da matriz nodular, liberando seus componentes solúveis, alumínio e sílica (Ambrosi et al., 1986). Parte do alumínio torna-se componente da Al-hematita com 4 a $15 \mathrm{~mol} \%$ de $\mathrm{Al}_{2} \mathrm{O}_{3}$. No entanto, a maior parte do alumínio e sílica liberados, migram a curtas distâncias e reprecipitam como uma nova geração de caulinita, entupindo alguns dos poros existentes na matriz argilosa situada entre ou abaixo dos nódulos. Nestes poros preenchidos, ferro pode concentrar-se novamente como hematita, reiniciando o mecanismo (Nahon, 1991).

Beauvais \& Tardy (1991) comentando sobre a formação e degradação de couraças ferruginosas, argumentam que a destruição desses materiais corresponde a desestabilização por hidratação da associação entre a caulinita remanescente e hematita, estáveis em meio pouco hidratado e oxigenado. Assim, os autores complementam que a degradação da couraça resulta da hidratação da hematita e de sua transformação em goetita, e em certos casos, da caulinita em gibbsita, originando os horizontes cascalhentos constituídos basicamente de pisolitos, amplamente distribuído na superficie dos perfis 
ferricretes (Ambrosi \& Nahon, 1986; Beauvais \& Tardy, 1991; Roquin, 1990 e Tardy, 1993).

Os mecanismos sugeridos acima por Nahon (1986) e Tardy \& Nahon (1985) evidenciam processos pedogenéticos no desenvolvimento dos ferricretes, ou seja, seu desenvolvimento essencialmente autóctone. Embora Tardy \& Roquin (1992, p. 413) e Roquin et al. (1990b) relatam que nos últimos 10 anos evidências de ferricretes autóctones foram acumuladas, argumentando que na "maioria dos casos, quartzo e minerais resistentes, bem como ferro e alguns elementos traços refletem a composição da rocha abaixo", numerosos estudos tem-se realizado nas "lateritas" dos baixos níveis topográficos, as quais são formadas predominantemente por acumulações absolutas de ferro, caracterizando as chamadas "lateritas" detritais (McFarlane, 1976). Esse caráter alóctone ou detrital é interpretado por Aleva (1994), McFarlane (1976) e Tardy \& Roquin (1992) como resultado tanto do transporte lateral do ferro em solução, precipitando em um saprolito litodependente, como formados por transporte mecânico de materiais, de modo que são completamente independentes da rocha abaixo. No entanto, McFarlane (1976, p.96) considera que mesmo nas "lateritas" dos baixos níveis topográficos, as quais são consideradas predominantemente de acumulações absolutas, o desenvolvimento in situ está freqüentemente associado, de modo que as "lateritas" nessas posições da vertente "são apenas parcialmente detritais". Evidências de aloctonia podem ser encontradas nos trabalhos recentes de Alexandre (1991), Bourman (1993) e Debaveye \& Dapper (1987). Esses autores tem referido unicamente ao transporte mecânico de materiais ferruginosos provenientes da erosão fisica, transporte e deposição de ferricretes pré-existentes nos altos niveis da paisagem e depositados nos seus níveis inferiores. Esses materiais podem posteriormente submeter-se a influxos laterais de ferro para formar carapaças contínuas através da recimentação das glébulas individuais (Sivarajasingham et al., 1962 e McFarlane, 1976).

As considerações acima correspondem a algumas das mais recentes interpretações dos mecanismos envolvidos na gênese dos ferricretes. Todas elas evidenciam o papel preponderante dos processos de lixiviação e acréscimo de matéria mineral, e objetivam 
elucidar "as causas da mobilização e concentração dos óxidos de ferro", processos "que ainda não foram suficientemente exploradas" nos estudos da gênese desses materiais, conforme já fora enunciado por Drosdoff \& Nikiforoff (1940, p. 341). 


\section{MATERIAL E MÉTODOS}

\subsection{Caracterização do meio físico}

\subsubsection{Localização, geologia, geomorfologia, clima e vegetação}

O estudo foi conduzido nas proximidades da Estação Experimental de Pindorama do Instituto Agronômico (IAC), região sul do município de Pindorama (SP). Localiza-se entre as coordenadas $21^{\circ} 13^{\prime}$ de latitude sul e $48^{\circ} 56^{\prime}$ de longitude oeste, com altitude média variando de 498 a 594 metros. A Figura 1 apresenta a localização da área estudada no Estado de São Paulo e em relação à Estação Experimental de Pindorama.

De acordo com o mapa geológico do Instituto de Pesquisas Tecnológicas do Estado de São Paulo - IPT (1981a) esta área situa-se na região mapeada como Grupo Bauru, formação Adamantina (Figura 2). Essa formação ocorre por vasta extensão no noroeste do Estado de São Paulo e caracteriza-se por apresentar bancos de arenitos de granulação fina a muito fina, alternados com lamitos, siltitos e arenitos lamíticos, sendo comuns a ocorrência de seixos de argilito, cimento e nódulos carbonáticos (Soares et al., 1980).

Geomorfologicamente a região em questão está inserida na Província Geomorfológica do Planalto Ocidental do Estado de São Paulo (IPT, 1981b) (Figura 3), caracterizado por um relevo regional suave, levemente ondulado, monótono, com predomínio de colinas e morrotes. Destacam-se platôs residuais, sustentados por rochas areniticas do Grupo Bauru. Esses platôs foram cartografados e definidos em quatro zonas, sendo que a área estudada localiza-se próximo ao Planalto de Catanduva, formado basicamente por erosão diferencial e que fez destacarem-se os maciços rochosos de forte cimentação carbonática. Lepsch \& Valadares (1976) caracterizaram o relevo da Estação 
Experimental de Pindorama como ondulado nas partes mais elevadas da paisagem, passando a suave-ondulado nas altitudes menores, sendo que a maior parte dos declives está compreendida entre 2 e 10\%, havendo pequenas áreas quase planas $(0-2 \%$ de declive) nos topos das elevações e nas várzeas, e algumas com declives entre 10 e $20 \%$ próximas a certos cursos d'água. A Figura 4 mostra uma fotomontagem, possibilitando uma visão geral da área estudada

O clima enquadra-se no tipo Aw, conforme a classificação de Köppen, definido como tropical úmido com estação chuvosa no verão e seca no inverno, com precipitação média anual de 1390,3 mm. A temperatura média dos três meses de verão (dezembro, janeiro e fevereiro) situa-se na faixa de $24,0^{\circ} \mathrm{C}$ e de $19,5^{\circ} \mathrm{C}$ a média dos três meses de inverno (junho, julho e agosto).

O balanço hídrico de Thornthwaite \& Mather (1955) como pode ser verificado na Figura 5, indica que os meses de julho, agosto e setembro são os mais secos e um considerável excedente hídrico ocorre principalmente nos meses de dezembro à março.

Observando os remanescentes florestais existentes na Estação e áreas vizinhas, Sparovek (1993) designou essa vegetação de Floresta Mesófila Semidecídua que se caracteriza por apresentar um dossel irregular e não perfeitamente contínuo entre 15-20 metros de altura, com a presença de árvores de até 25 a 30 metros e deciduidade concentrada na estação seca em aproximadamente $20 \%$ das espécies. 


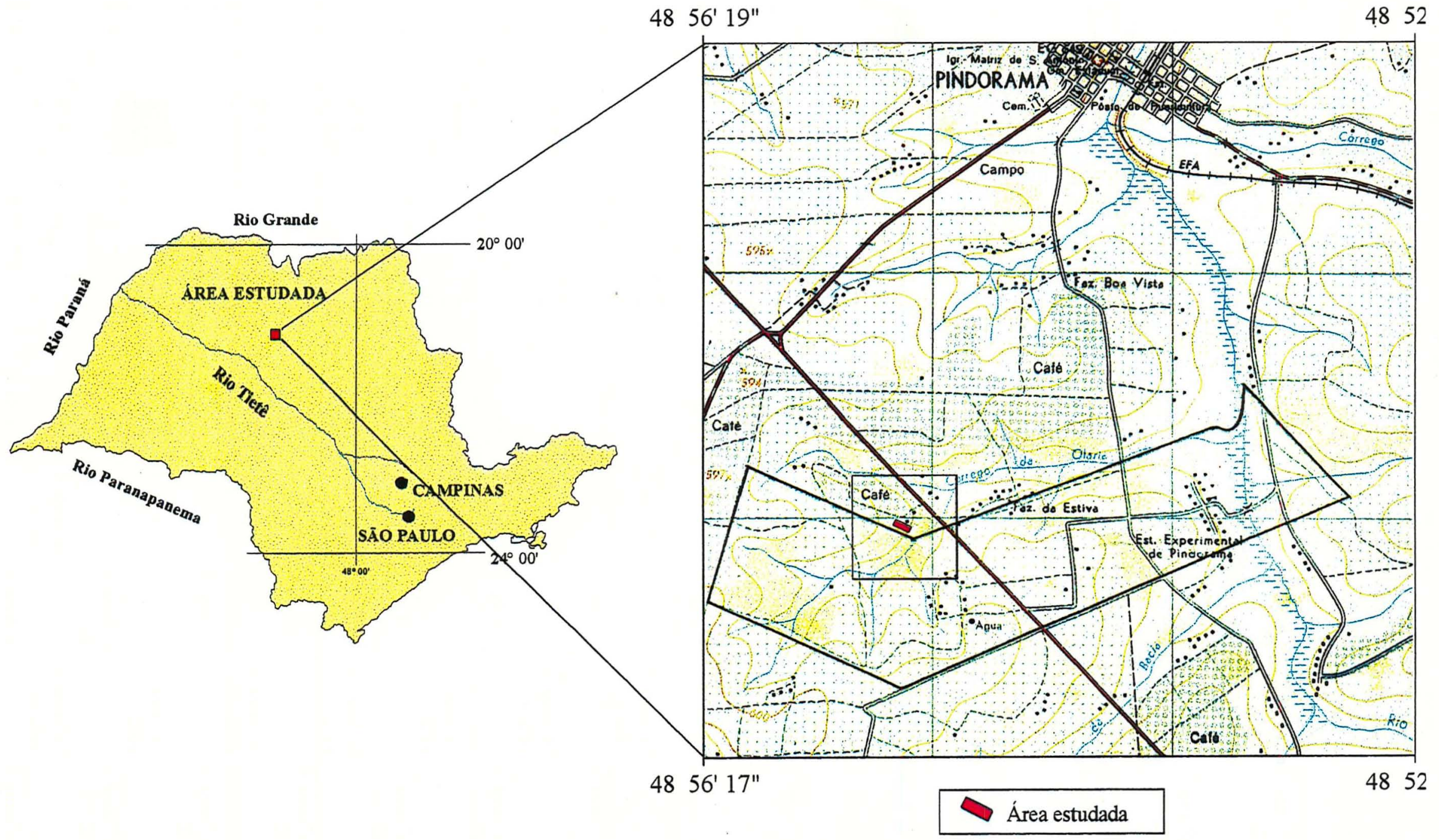

Figura 1. Localização da área estudada no Estado de São Paulo e nas proximidades da Estação Experimental de Pindorama - IAC (SP) 


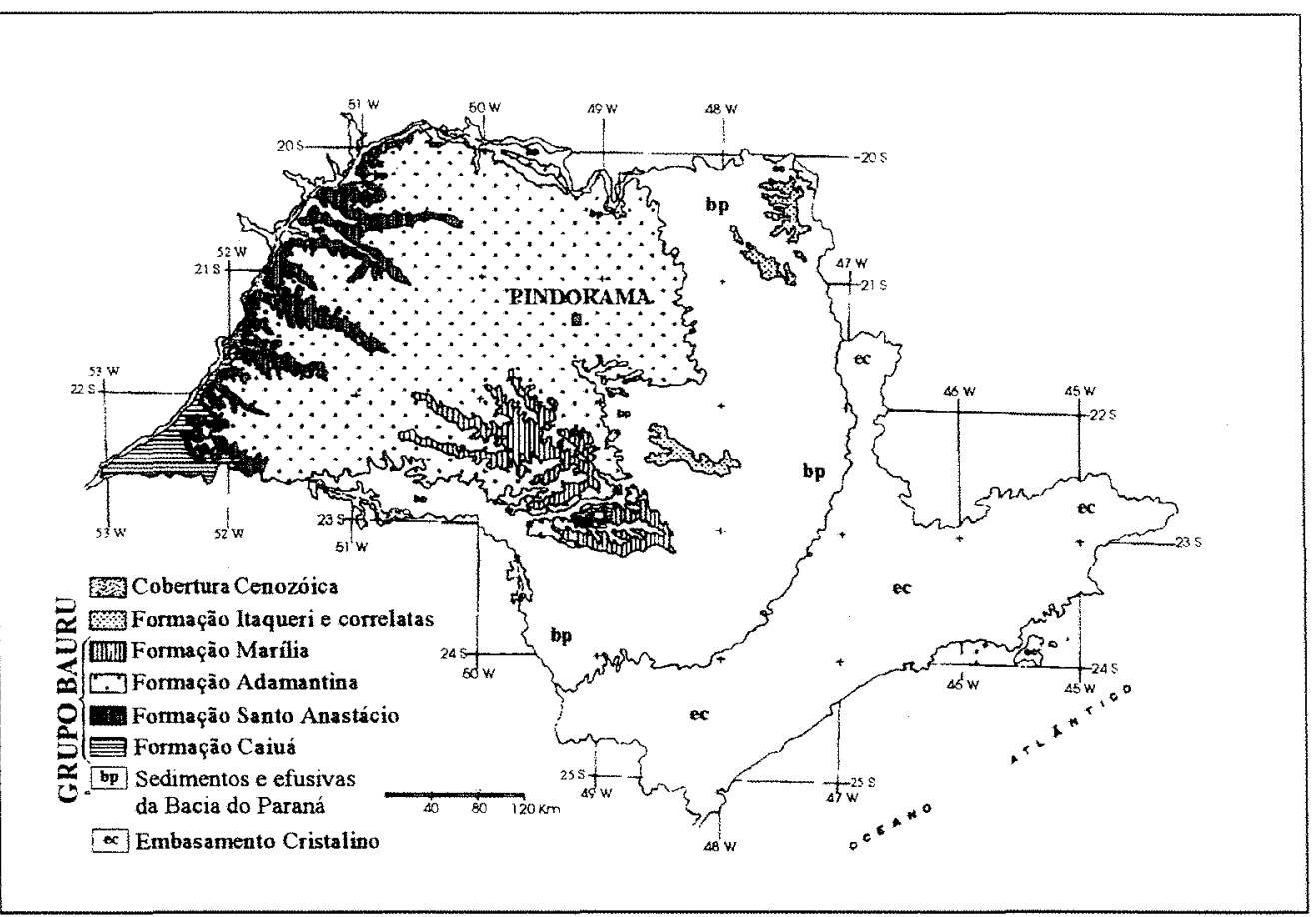

Figura 2. Distribuição do Grupo Bauru, formação Itaqueri e correlatas no Estado de São Paulo. Fonte: IPT (1981a).

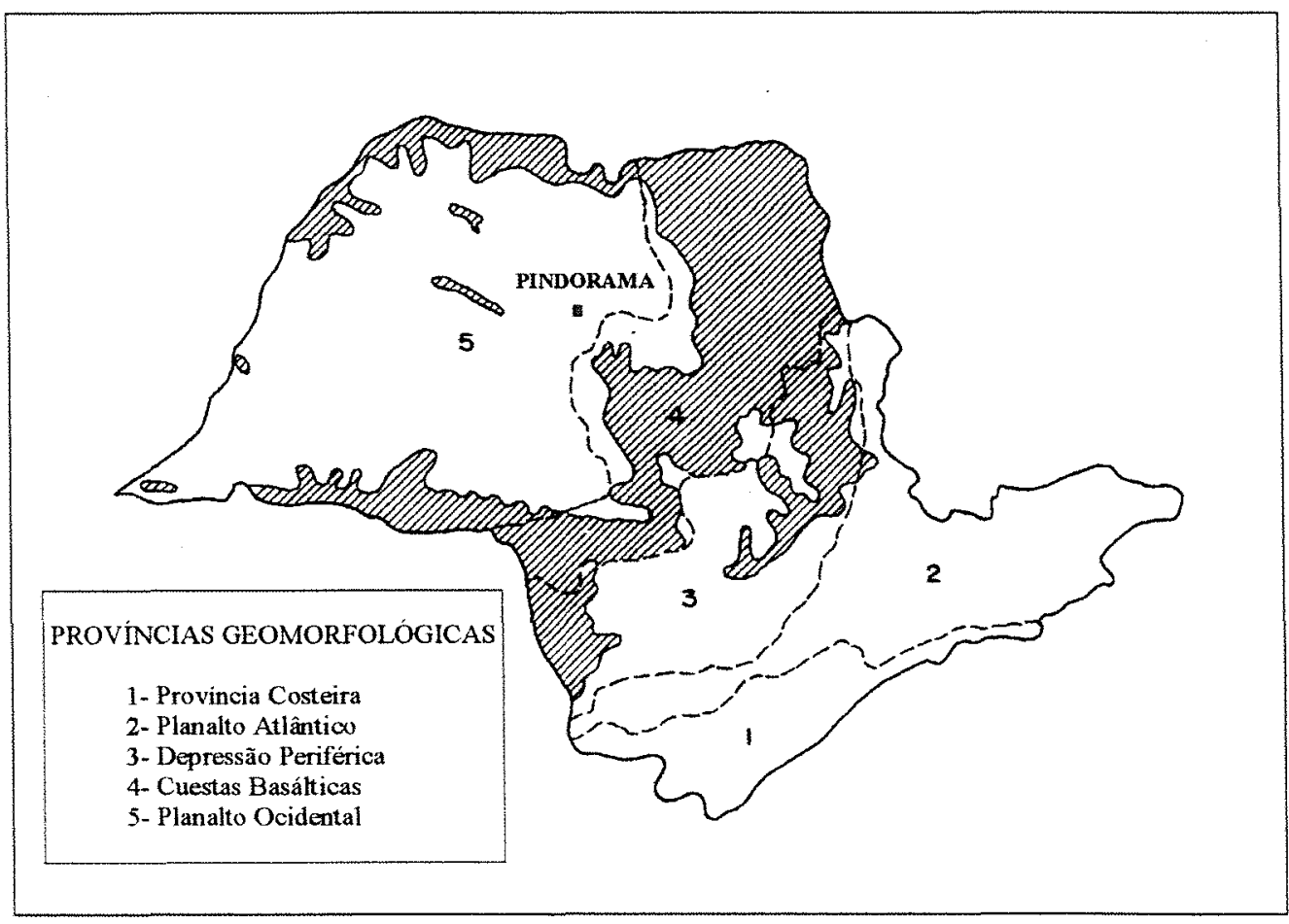

Figura 3. Províncias Geomorfológicas do Estado de São Paulo. Fonte: Oliveira e Menk (1984). 

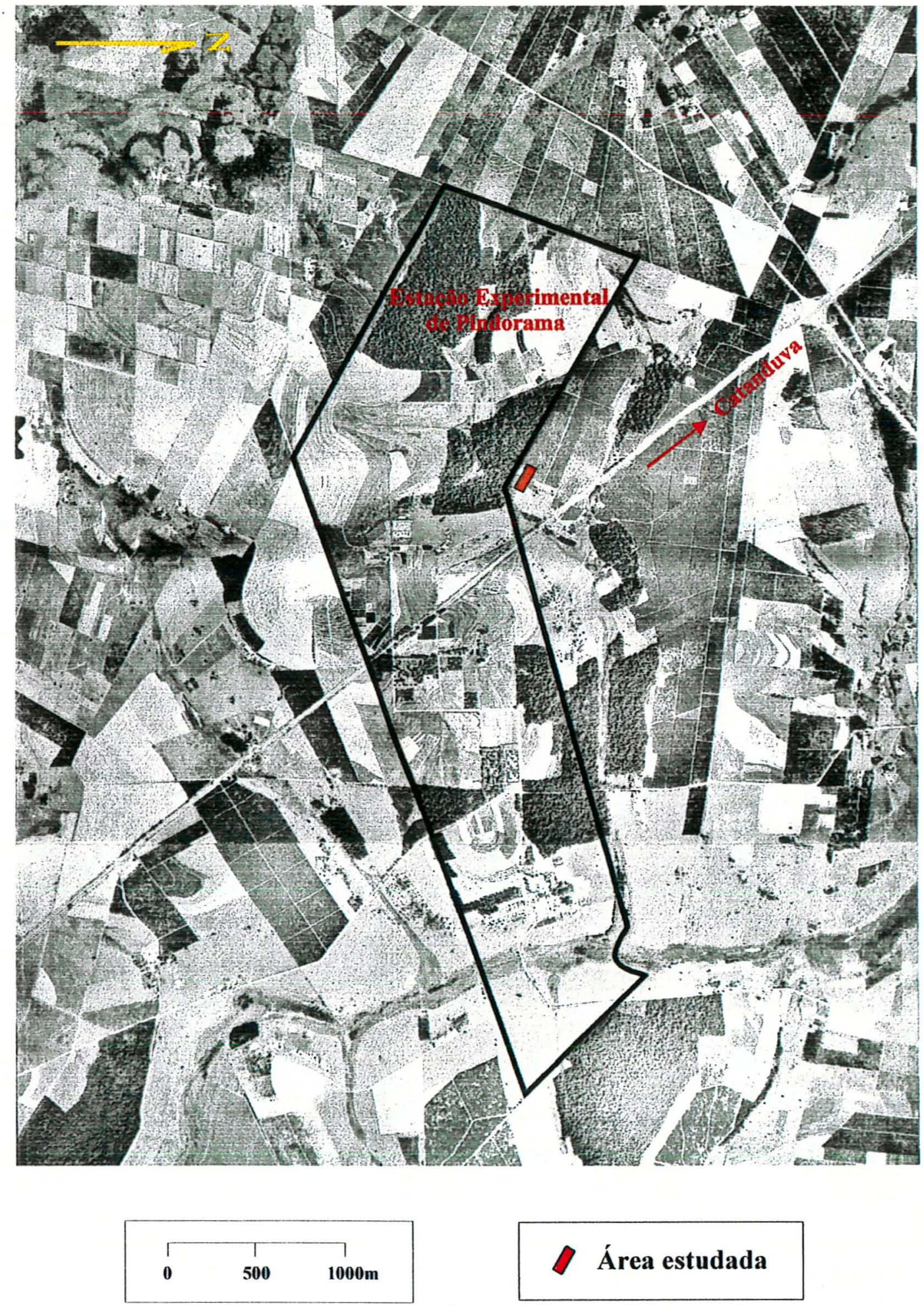

\section{$\triangle$ Área estudada}

Figura 4. Fotomontagem com as localizações da Estação Experimental e da seqüência estudada. 


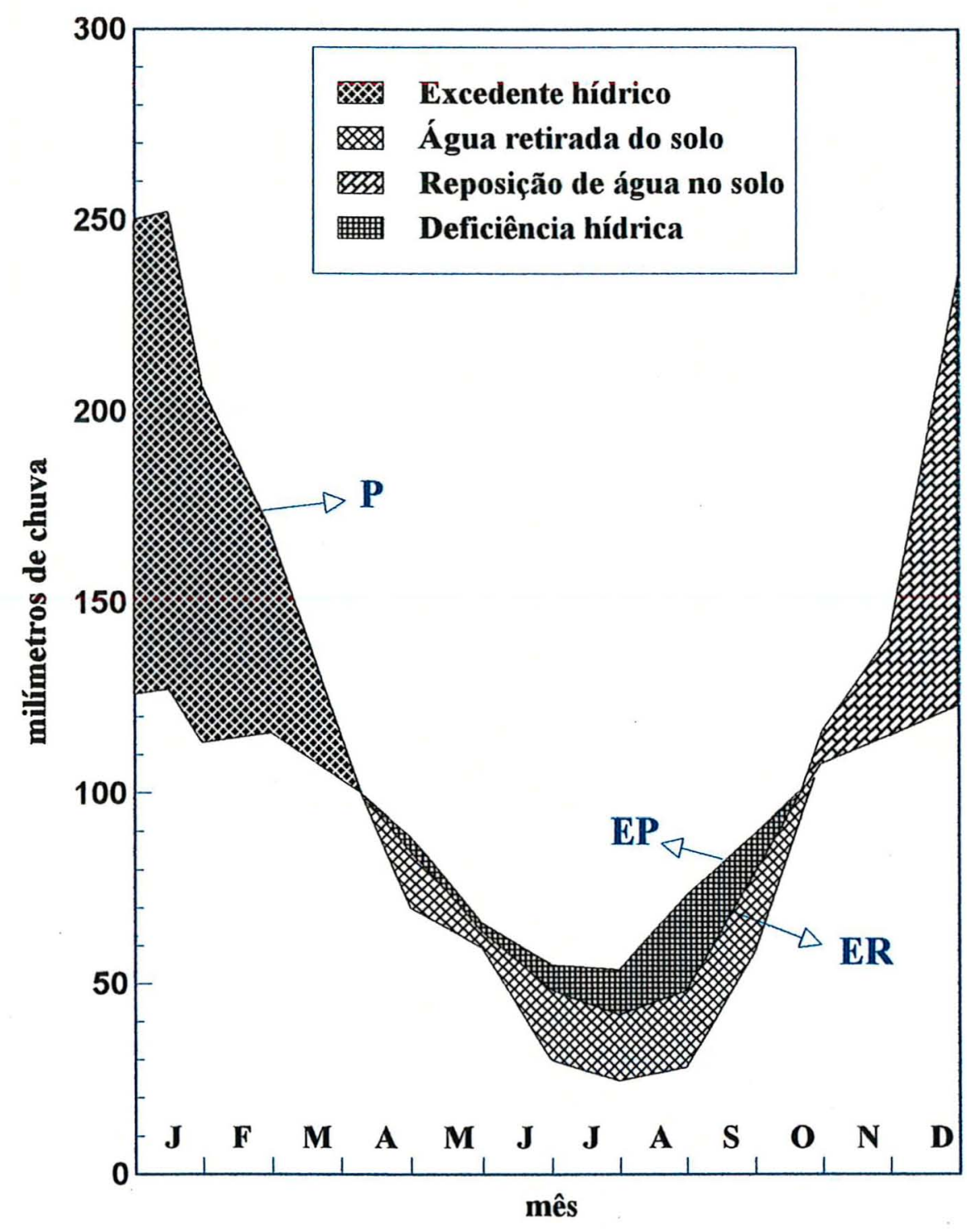

Figura 5. Balanço hídrico anual da Estação Experimental de Pindorama (1961 a 1990). P $($ precipitação $)=1390,2 \mathrm{~mm}$; EP (evapotranspiração potencial $)=1129,0 \mathrm{~mm}$; ER (evapotranspiração real) $=1061,9 \mathrm{~mm}$; deficiência hídrica $=67,1 \mathrm{~mm}$; excedente hídrico $=328,3 \mathrm{~mm}$. Fonte: Centro de Ecofisiologia e Biofísica Instituto Agronômico (IAC). 


\subsubsection{Solos}

A Figura 6 apresenta as Unidades de solos delimitadas no Levantamento Pedológico Detalhado da Estação Experimental de Pindorama (Lepsch \& Valadares, 1976). As Unidades Concreção (Co), Pindorama (Pi) e Serrinha (Se) localizam-se próximo a área escolhida para este estudo, as quais serão brevemente descritas conforme os autores e classificados segundo Camargo et al. (1987).

Unidade Pindorama (Pi): Solos profundos, bem desenvolvidos, bem drenados e eutróficos. Apresentam horizontes A e E com aproximadamente 30 a $45 \mathrm{~cm}$ de espessura sobre horizonte argílico. Foi classificado como Solos Podzolizados de Lins e Marilia, variação Marilia conforme Comissão de Solos (1960) e atualmente são classificados como Podzólico Vermelho-Amarelo $\mathrm{Tb}$ Eutrófico Abrupto A moderado textura arenosa/média.

Unidade Serrinha (Se): São solos profundos, bem desenvolvidos e bem drenados, eutróficos. Apresentam horizontes A e E com normalmente 50 a $60 \mathrm{~cm}$ de espessura, textura arenosa fina e cor bruna ou bruno-avermelhada sobre horizonte argílico. Classificado segundo Comissão de Solos (1960) como Solos Podzolizados de Lins e Marilia, variação Marilia. Atualmente são classificados como Podzólico VermelhoAmarelo Tb Eutrófico Abrupto A moderado, textura arenosa/média. Portanto, difere da Unidade anterior pela espessura dos horizontes $\mathrm{A}+\mathrm{E}$.

Unidade Concreção (Co): Solos moderadamente profundos, moderadamente desenvolvidos e moderadamente drenados. Apresentam horizontes A e E de espessura variáveis, de textura arenosa fina sobre horizonte argilico e uma camada de concreções ferruginosas de 15 a $30 \mathrm{~cm}$ de espessura, localizadas ou logo abaixo do horizonte $A$ ou no interior do horizonte argílico. $\mathrm{O}$ arenito decomposto aparece à profundidade entre 150 a $200 \mathrm{~cm}$. Classificação atual: Plintossolo Pétrico moderadamente drenado $\mathrm{Tb}$ Distrófico A moderado textura arenosa/média. 


\subsection{Trabalho de campo.}

O trabalho de campo consistiu no estabelecimento do segmento de vertente com ocorrência de feições ferruginosas, abertura de trincheiras e amostragem dos diferentes horizontes nos perfis estudados, bem como no detalhamento desse segmento através do procedimento de análise estrutural da cobertura pedológica.

\subsubsection{Estabelecimento do segmento de vertente}

Após percorrer toda a área da Estação Experimental de Pindorama delimitada no mapa de solos como Unidade Concreção (Figura 6), bem como as propriedades rurais confrontantes, com auxílio de um trado e enxadão foi identificado o segmento de vertente que melhor caracterizava as diferentes classes de solo com ocorrências expressivas e representativas das feições ferruginosas. As Figuras 6 e 7 mostram a localização da área estudada em relação à Estação Experimental de Pindorama e evidenciam a posição do segmento no sopé da vertente e em uma propriedade confrontante à Estação. 


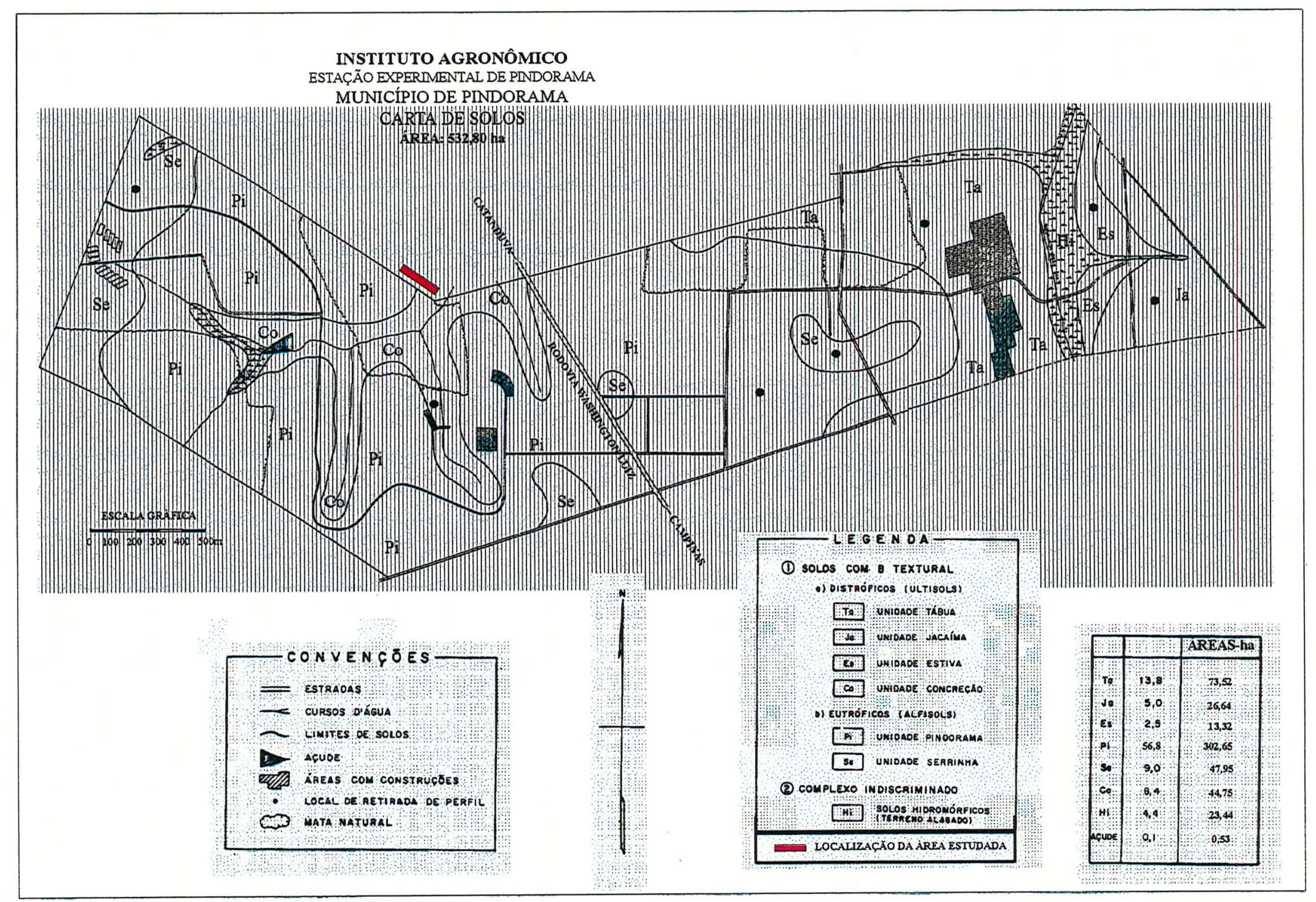

Figura 6. Mapa de solos da Estação Experimental de Pindorama e loçalização da seqüência estudada em uma propriedade confrontante à Estação. Fonte: Lepsch \& Valadares (1976) 


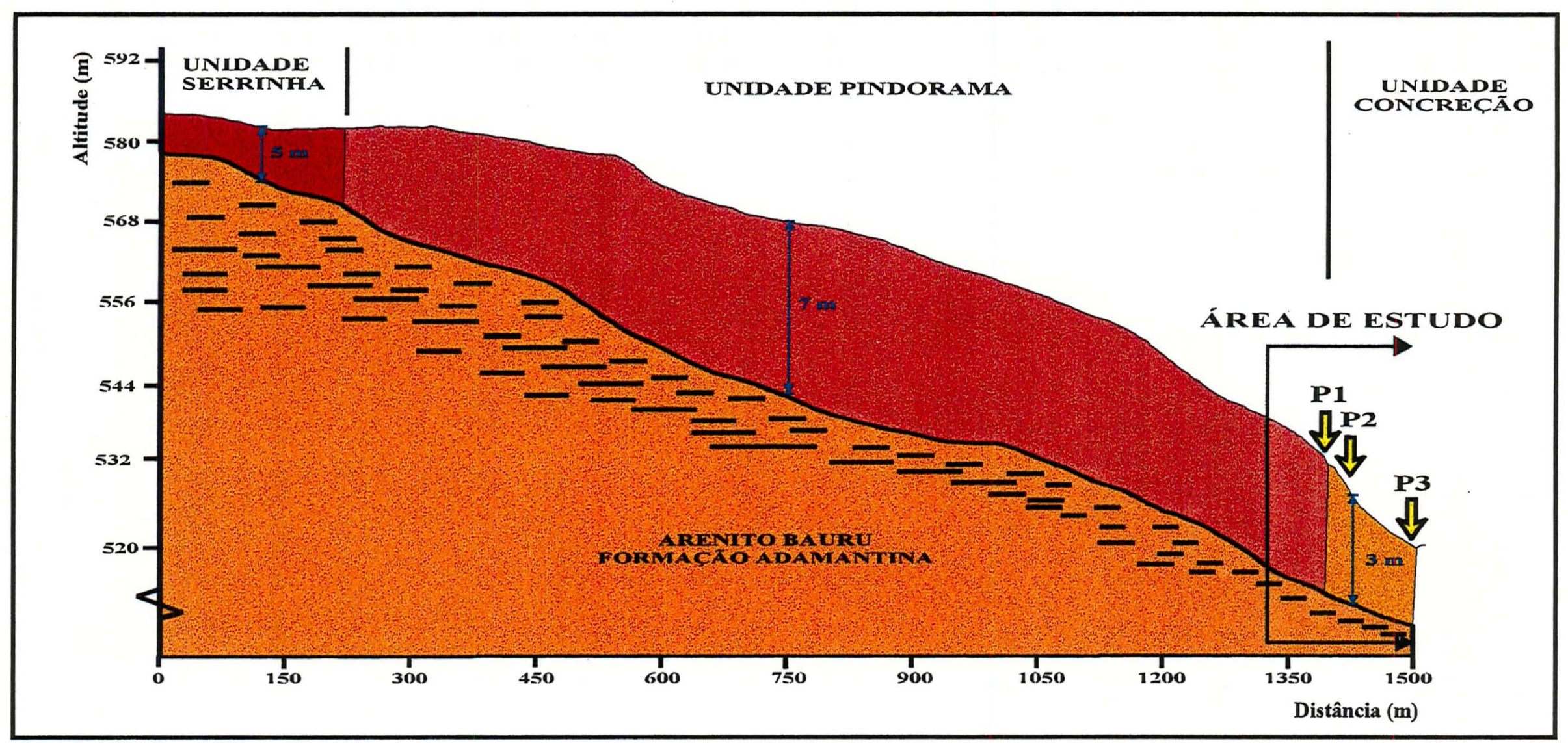

Figura 7. Posição esquemática dos perfis na paisagem. 


\subsubsection{Abertura de trincheiras a amostragem de solos}

Conhecido o segmento da vertente, foram abertas 3 trincheiras. A localização dessas no sopé da vertente foram definidas após tradagens preliminares, possibilitando a identificação expedita da variação lateral dos horizontes seguindo metodologia proposta por Boulet et al. (1982). Parâmetros como a espessura do horizonte ferricrete, tipos de horizontes acima da couraça, bem como a presença de mosqueados, definiram as posições dos perfis estudados.

Nas trincheiras foram realizadas descrições morfológicas seguindo as normas do Manual de Descrição e Coleta de Solo no Campo (Lemos \& Santos, 1996), coletadas amostras deformadas para análises granulométricas, químicas e mineralógicas, bem como amostras indeformadas e orientadas para análise micromorfológica.

\subsubsection{Análise estrutural do segmento de vertente}

Para maior detalhamento do segmento de vertente foi realizado um estudo bidimensional da configuração lateral dos diferentes horizontes seguindo uma etapa da metodologia de análise estrutural proposta por Boulet et al. (1982). A Figura 8 mostra o segmento de vertente estudado com a localização dos perfis P1, P2 e P3. O desaparecimento das feições ferruginosas a montante dos perfis estabeleceu o limite superior do segmento estudado e seu limite inferior é a trincheira 3, onde mosqueados constituem as únicas feições ferruginosas. Comparou-se a morfologia dos horizontes dentro do segmento e a partir dessas observações, desenhou-se em papel milimetrado toda a sequência vertical e lateral desses horizontes, permitindo a visualização de todo segmento em corte longitudinal. 


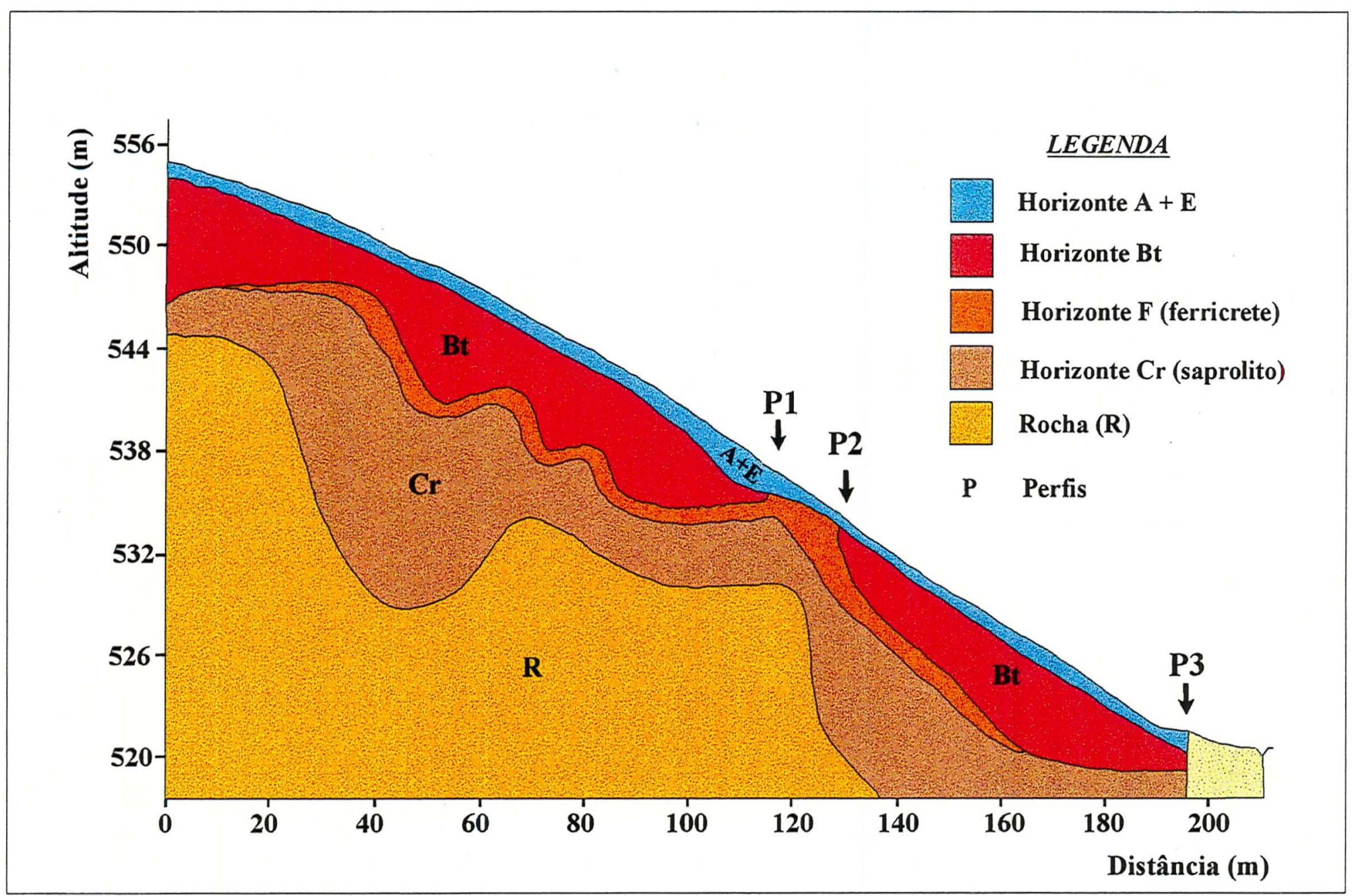

Figura 8. Representação esquemática do segmento de vertente estudado com a localização dos perfis P1, P2 e P3 e distribuição lateral e vertical dos diferentes horizontes. 


\subsection{Procedimento de laboratório}

No laboratório as amostras de solo foram secas ao ar, destorroadas com um martelo de borracha e passadas em peneira $\mathrm{n}^{0} 10$ (malha de $2 \mathrm{~mm}$ ), obtendo a fração terra fina seca ao ar (TFSA) onde foram realizadas as análises granulométricas. As amostras de solo utilizadas para as análises químicas e mineralógicas foram posteriormente passadas em peneira $\mathrm{n}^{\circ} 18$ (malha de $1 \mathrm{~mm}$ ) para a remoção de glébulas decimilimétricas.

Amostras provenientes dos horizontes ferricrete foram submetidas ao peneiramento por via úmida em peneira $\mathrm{n}^{\circ} 10$ para separar as glébulas da matriz interglebular. Posteriormente, as glébulas foram individualmente escovadas em água corrente para remoção do solo aderido, secas ao ar, trituradas em moinho mecânico e passadas em peneira $\mathrm{n}^{\mathrm{o}} 10$. O solo do horizonte ferricrete (matriz interglebular) foi seco ao ar, sendo parte destinado a determinação granulométrica (peneira $n^{0} 10$ ) e parte passado em peneira $\mathrm{n}^{0} 18$ para as determinações químicas e mineralógicas. Apenas o horizonte plíntico do perfil P2 foi submetido aos procedimentos convencionais de preparo das amostras, ou seja, as glébulas e matriz foram homogeneizadas com martelo de borracha e passadas em peneira

\subsubsection{Análises Físicas}

\section{a) Análises granulométricas}

A distribuição dos separados do solo na fração menor que $2 \mathrm{~mm}$ (TFSA) foi determinada pelo método da pipeta conforme recomendações de Camargo et al. (1986). Para tal, amostras de $10 \mathrm{~g}$ foram agitadas por 16 horas com hexametafosfato de sódio e hidróxido de sódio como agentes dispersantes.

\subsubsection{Análises Químicas}

Os procedimentos analíticos realizados para as determinações das análises pedológicas de rotina e elementos totais das amostras foram os mesmos utilizados nos laboratórios do Departamento de Ciência do Solo da ESALQ/USP e estão descritos abaixo: 


\subsubsection{Análises químicas de rotina}

Essas determinações seguiram as metodologias recomendadas por Raij et al. (1987).

Para determinação da reação do solo foram medidos $\mathrm{pH}$ em $\mathrm{H}_{2} \mathrm{O}$, em $\mathrm{KCl} 1 \mathrm{~N}$ e em $\mathrm{CaCl}_{2}$ 0,01M. A matéria orgânica foi determinada após oxidação com dicromato de potássio e titulação com sulfato ferroso amoniacal. Para a determinação do alumínio trocável, utilizou-se $\mathrm{KCl} 1 \mathrm{~N}$ como solução extratora. A acidez potencial $(\mathrm{H}+\mathrm{Al})$ foi obtida após extração com acetado de cálcio $1 \mathrm{~N}$ a pH 7,0. Cálcio, magnésio, potássio trocáveis e fósforo foram determinados pelo método da resina de troca iônica.

\subsubsection{Elementos Totais (Ataque Sulfúrico)}

\section{a) Obtenção dos extratos ácido e alcalino}

Para as determinações das análises químicas totais através do ataque sulfúrico foi utilizado a metodologia preconizada por Vettori (1969) com algumas modificações proposta por Raij \& Valadares (1974), seguindo os procedimentos realizados nos laboratórios da ESALQ/USP.

Amostra de $1000 \mathrm{mg}$ de solo foram transferidas para um tubo digestor, adicionados $20 \mathrm{ml}$ de solução de ácido sulfúrico $18 \mathrm{~N}$ e deixado ferver durante meia hora em bloco digestor. Após digestão ácida procedeu-se a filtragem, recebendo todo o filtrado em balão volumétrico de $250 \mathrm{ml}$ e transferido todo o material sólido para papel de filtro. O resíduo foi lavado várias vezes com água e completou-se o volume dos balões volumétricos com água desionizada. Os balões continham o extrato do ataque sulfúrico (extrato ácido) o qual foi utilizado para as determinações totais de alumínio (Al), ferro (Fe), titânio (Ti) e manganês (Mn).

O resíduo do papel de filtro foi transferido na sua totalidade para erlemmeyer com o auxílio de uma pisseta e a seguir adicionados aproximadamente $150 \mathrm{ml}$ de água desionizada e $4 \mathrm{ml}$ de $\mathrm{NaOH}$ a $30 \%$. Seqüencialmente foram fervidos durante 1 minuto, deixados esfriar e passados para um balão volumétrico de $250 \mathrm{ml}$., completado o volume, homegeneizado e filtrado com papel de filtro faixa azul. O filtrado (extrato alcalino) foi 
acondicionado em recipiente de plástico, o qual foi utilizado para a determinação de silicio total (Si)

\subsubsection{Dissoluções Seletivas}

As determinações de ferro, alumínio e manganês livres e amorfos, bem como as formas de ferro extraíveis com pirofosfato foram determinadas segundo o "Manual for Soil and Water Analysis" editado por Buurman et al. (1996). Para as determinações de ferro e manganês facilmente redutiveis utilizou-se a metodologia proposta por (Gambrell, 1996). Todos os elementos foram medidos em espectrofotômetro de absorção atômica.

\section{a) Ferro, alumínio e manganês livres}

Compostos de ferro, alumínio e manganês livres, tais como goetita, gibbsita e birnessita, são extraídos após a redução dos elementos em meio tampão de citrato e ditionito (DC). Esse método é denominado método de "Holmgren" (Buurman et al. 1996):

\section{b) Ferro e alumínio amorfos}

Os compostos de ferro, alumínio e manganês amorfos foram extraídos em solução ácida de oxalato após agitação no escuro durante 4 horas.

\section{c) Ferro extraivel com pirofosfato}

O ferro associado a matéria orgânica nos solos é extraído em solução de pirofosfato de sódio em meio alcalino $(\mathrm{pH}>9)$, conforme metodologia proposta por Buurman et al. (1996). Após agitação durante toda a noite, foram transferidos aproximadamente $25 \mathrm{ml}$ da amostra para tubos de centrífuga de $50 \mathrm{ml}$, centrifugado em ultracentrífuga a $20.000 \mathrm{rpm}$ durante 30 minutos e posteriormente passados em papel filtro faixa azul. 


\section{d) Ferro e manganês facilmente redutiveis}

Para esta determinação utilizou-se o método da "Hidroxilamina" descrito por Gambrell (1996).

\subsubsection{Análises mineralógicas}

\section{a) Mineralogia da fração argila desferrificada}

Todo o preparo e tratamento das amostras para a determinação da composição das frações argila desferrificada foram feitos de acordo com Jackson (1969).

As amostras de argila desferrificada foram saturadas com $\mathrm{KCl}$ e $\mathrm{MgCl}_{2}$. As amostras saturadas com potássio foram transferidas com espátula e orientadas em lâminas de vidro $(3 \times 4 \mathrm{~cm})$. Após secagem foram irradiadas a temperatura ambiente $\mathrm{e}$ posteriormente aquecidas a $350^{\circ} \mathrm{C}$ durante 2 horas em mufla, resfriadas e novamente irradiadas. $\mathrm{O}$ último procedimento para as amostras saturadas em $\mathrm{K}$ foi o aquecimento das lâminas à $550^{\circ} \mathrm{C}$ durante 2 horas com posterior irradiação no difratômetro de raio $\mathrm{X}$.

As amostras saturadas com $\mathrm{Mg}$ foram transferidas para lâminas (amostra orientada) e receberam os seguintes tratamentos: (1) secagem à temperatura ambiente e irradiação; (2) a mesma lâmina sofreu glicolação (etileno-glicol a 10\%) e irradiação.

Os difratogramas de raio $\mathrm{X}$ foram obtidos com tubo ânodo de cobre com filtro de níquel e a unidade de força operando com $40 \mathrm{KV}$ e $20 \mathrm{~m} \AA$. A irradiação para os diferentes tratamentos foi de $3^{\circ}$ aos $30^{\circ} 2 \theta$.

A caulinita foi identificada por seus picos de difração a 7,14 - 7,29 $\AA$ e 3,49- 3,53

$\AA$, os quais desapareceram pelo aquecimento a $550^{\circ} \mathrm{C}$; a gibbsita, por seu pico a $4,85 \AA$ que desaparece a $350^{\circ} \mathrm{C}$; a mica, por seu pico de difração ao redor de $10 \AA$, por não sofrer expansão com a solvatação quando tratada com etileno-glicol, e também por continuar presente na amostra após o aquecimento a $550^{\circ} \mathrm{C}$. Esses procedimentos seguem sugestões de Brown (1961). 


\section{b) Mineralogia dos óxidos de ferro}

Para a caracterização mineralógica dos óxidos de ferro procedeu-se a metodologia descrita por Norrish \& Taylor (1961) a qual foi modificada por Kämpf \& Schwertmann (1982).

Inicialmente a fração argila foi separada utilizando $\mathrm{NaOH} 0,01 \mathrm{M}$ com agente dispersante e tendo como base o princípio da lei de Stokes. Após o tempo de sedimentação adequado, a suspensão foi sifonada para cadinhos de porcelana e secas em estufa a $60^{\circ} \mathrm{C}$. A argila seca foi moída em almofariz e passada na peneira de $0,210 \mathrm{~mm}$.

A concentração dos óxidos de ferro na fração argila foi realizada utilizando-se $\mathrm{NaOH} 5 \mathrm{M}$ a quente. Um grama da argila foi transferida para copos altos de aço inoxidável e $100 \mathrm{ml}$ de $\mathrm{NaOH} 5 \mathrm{M}$ foram adicionados. A seguir a suspensão foi fervida a $105^{\circ} \mathrm{C}$ em chapa quente durante 1 hora, promovendo a completa remoção da caulinita e gibbsita da amostra. As amostras foram resfriadas em água corrente, centrifugadas (2000 rpm durante $5 \mathrm{~min}$ ) e o sobrenadante descartado. Os resíduos foram seqüencialmente lavados com $\mathrm{NaOH} 5 \mathrm{M}, \mathrm{HCl} 0,5 \mathrm{M}$ (para dissolver a sodalita), $\left(\mathrm{NH}_{4}\right)_{2} \mathrm{CO}_{3}$ (para remover o excesso de $\mathrm{Na}$ ) e duas vezes com água destilada. Esses resíduos foram colocados em cadinhos e secos em estufa a $110^{\circ} \mathrm{C}$ pelo menos durante 12 horas para remover o excesso de $\mathrm{NH}_{4}$ e $\mathrm{CO}_{3}$. A seguir foram transferidos e moídos em almofariz e posteriormente peneirados.

Os óxidos de ferro concentrados foram analisados por difratometria de raios $\mathrm{X}$ (DRX). O difratômetro, equipado com tudo de cobalto e filtro de ferro, foi operado com $26 \mathrm{~mA}$ e $36 \mathrm{KV}$, sendo a lâmina montada em pó (não orientada) com $30 \%$ de quartzo finamente moído, recebendo uma suave prensagem com papel-filtro. $\mathrm{O}$ acréscimo do quartzo em cada amostra foi utilizado para corrigir os valores das posições dos picos da hematita e goetita no cálculo da substituição isomórfica por alumínio nesses minerais, seguindo recomendações de Netto (1996). 


\section{b.1) Estimativa da substituição isomórfica na hematita (Hm) e goetita (Gt)}

A substituição isomórfica dos óxidos de ferro foram determinados tanto por difração de raio $\mathrm{X}$ como através de métodos quimicos.

\section{b.1.1.) Determinação da substituição isomórfica por difratometria de raio $X$}

A substituição isomórfica por alumínio dentro das estruturas da $\mathrm{Hm}$ e $\mathrm{Gt}$ foram determinadas utilizando-se equações publicadas que relacionam o parâmetro unidade da cela (posição do pico obtidos por DRX) ao conteúdo de Al. Para $\mathrm{Hm}$, a equação desenvolvida por Schwertmann et al. (1979) foi escolhida, na qual a dimensão da cela unitária $a_{0}$ foi obtida ou da posição do pico $d_{(110)}$ ou do pico $d_{(300)}$, segundo a equação:

$$
A l=3.076,8-610,7 \times a_{o}
$$

onde

$$
\begin{aligned}
& \mathrm{Al}=\text { substituição isomórfica por } \mathrm{Al} \mathrm{em} \mathrm{mol} \mathrm{\%} \\
& \mathrm{a}_{0}=\mathrm{d}_{(110)} \times 2, \text { ou } \mathrm{a}_{0}=\mathrm{d}_{(300)} \times 3,464 \\
& \text { e em que } \\
& \mathrm{d}_{(110)}=\text { espaçamento interplanar para } \mathrm{Hm} 110 \mathrm{em} \AA \\
& \mathrm{d}_{(300)}=\text { espaçamento interplanar para } \mathrm{Hm} 300 \mathrm{em} \AA
\end{aligned}
$$

A porcentagem de substituição isomórfica da Gt foi determinada segundo Schulze (1982), quem calculou a dimensão $c_{o}$ da cela unitária da goetita usando as posições dos picos $d_{(110)}$ e $d_{(111)}$. Então:

$$
\begin{aligned}
& A l=1730-572 \times c_{o}, \text { sendo } \\
& c_{o}=\left[\left(1 / d_{(111)}\right)^{2}-\left(1 / d_{(110)^{2}}\right]^{-0,5}\right.
\end{aligned}
$$


em que
$\mathrm{Al}=$ substituição isomórfica por $\mathrm{Al}$ em mol \%
$\mathrm{c}_{\mathrm{o}}=$ dimensão $\mathrm{c}$ da cela unitária da $\mathrm{Gt}$
$\mathrm{d}_{(111)}=$ espaçamento interplanar para a Gt $111 \mathrm{em} \AA$
$\mathrm{d}_{(110)}=$ espaçamento interplanar para a Gt $110 \mathrm{em} \AA$

\section{b.1.2) Determinação da substituição isomórfica através de métodos químicos}

Foram utilizadas duas equações que consideram os valores de ferro e alumínio extraídos com DC e oxalato-oxálico. A primeira foi desenvolvida por Guillet \& Jeanroy (1993) e utilizada Barral (1987), quem obteve uma boa correlação com os valores obtidos por difratometria de raios $\mathrm{X}$ para amostras predominantemente goetíticas. Essa equação refere-se apenas a substituição isomórfica na goetita e é representada por:

$$
A l=\frac{\left(A l_{d}-A l_{o}\right) / 27 \times 100}{\left(A l_{d}-A l_{o}\right) / 27+\left(F e_{d}-F e_{o}\right) / 55,8}
$$

em que

$\mathrm{Al}=$ substituição isomórfica por $\mathrm{Al}$ na goetita $\mathrm{em} \mathrm{mol} \mathrm{\%}$

$\mathrm{Al}_{\mathrm{d}}$ e $\mathrm{Fe}_{\mathrm{d}}=$ alumínio e ferro extraídos com DC

$\mathrm{Al}_{\mathrm{o}}$ e $\mathrm{Fe}_{\mathrm{o}}=$ alumínio e ferro extraídos com o reagente oxalato-oxálico

A segunda equação foi obtida do trabalho de Shadfan et al. (1985). Esses autores determinaram o conteúdo de alumínio na estrutura dos óxidos de ferro através da seguinte equação, porém, não discriminando o tipo de óxido:

$$
A l=\frac{A l_{d}-A l_{o} \times 100}{A l_{(d-o)}+F e_{(d-o)}}
$$

onde

$\mathrm{Al}=$ substituição isomórfica por $\mathrm{Al}$ nos óxidos de ferro $(\mathrm{Hm}+\mathrm{Gt})$ 


\section{b.2) Cálculo da relação $\mathrm{R}(\mathrm{Hm} / \mathrm{Hm}+\mathrm{Gt})$}

A relação $\mathrm{R}$ foi estimada com base nas áreas dos picos da $\mathrm{Hm}$ e $\mathrm{Gt}$. A fórmula utilizada para cálculo foi sugerida por Resende et al. (1987) e consta da seguinte equação:

$$
R=\frac{H m}{H m+G t}=1 \div\left(\frac{A G t_{110}}{A H m 104 \times 0,708}+1\right)
$$

em que

AGt $110=$ área sob o pico da Gt 110.

AHm 104 = área sob o pico da $\mathrm{Hm} 104$

\section{b.3) Cálculo dos conteúdos de Hm e Gt}

Procedeu-se a estimativa quantitativa da mineralogia dos óxidos de ferro utilizando-se o método da alocação proposto por Resende et al. (1987), o qual foi modificado por Netto (1996). Os elementos químicos dos minerais extraídos pelo ataque sulfúrico e ditionito-citrato (DC) na fração argila, foram alocados nos minerais identificados por DRX (NaOH $5 \mathrm{M}) . \mathrm{O} \mathrm{Fe}_{2} \mathrm{O}_{3}$ do $\mathrm{DC}$ foi alocado na $\mathrm{Hm}$ e Gt, considerando a relação $\mathrm{R}$ e a substituição isomórfica da $\mathrm{Hm}$ e $\mathrm{Gt}$, através das seguintes equações:

$$
\begin{aligned}
& H m=\left(R \times \mathrm{Fe}_{2} \mathrm{O}_{3}\right) \times 1000 \div\{[\mathrm{FeGt} \times(1-\mathrm{R})]+\mathrm{R} \times \mathrm{FeHm}\} \\
& \mathrm{e} \\
& G t=[\mathrm{Hm} \times(I-\mathrm{R})] \div R
\end{aligned}
$$

em que

$\mathrm{Hm}=$ conteúdo de $\mathrm{Hm}$ em $\mathrm{g} / \mathrm{Kg}$

$\mathrm{Gt}=$ conteúdo de $\mathrm{Gt}$ em $\mathrm{g} / \mathrm{Kg}$

$\mathrm{Fe}_{2} \mathrm{O}_{3}=$ teor fracional extraído com DC 
$\mathrm{R}=$ teor fracional da relação $\mathrm{Hm} / \mathrm{Hm}+\mathrm{Gt}$

$\mathrm{FeGt}=$ conteúdo de $\mathrm{Fe}_{2} \mathrm{O}_{3}$ na goetita expresso pela fórmula:

$$
F e G t=\frac{80 *(1-x)}{89-29 * x}
$$

$\mathrm{FeHm}=$ teor fracional de $\mathrm{Fe}_{2} \mathrm{O}_{3}$ na hematita expresso pela fórmula:

$$
F e H m=\frac{160 *(1-x)}{160-58 * x}
$$

onde $x$ é a substituição isomórfica de Fe por $\mathrm{Al}$ em teor fracional molar

\subsubsection{Análises micromorfológicas}

Após descrição morfológica detalhada dos perfis, foram coletadas amostras indeformadas e orientadas dos principais horizontes e das transições entre eles. Estas amostras foram secas ao ar e antes da impregnação procedeu-se secagem em estufa a $45^{\circ} \mathrm{C}$ durante 2 dias para prevenir a permanência de alguma umidade ainda restante. Para a impregnação, utilizou-se uma mistura em partes iguais de resina poliester Polilyte e solvente monômero de estireno, acrescentando algumas gotas de peróxido de metil-etilcetona como catalizador para a polimerização do poliester final (Castro, 1985). Após o endurecimento, as amostras foram cortadas, coladas em lâminas de vidro para microscopia e polidas em laminadora até próximo a espessura considerada adequada (30 $\mu \mathrm{m})$. O polimento final foi feito com pó de carborundum de granulometria cada vez mais fina, até os grãos de quartzo apresentarem-se em tons amarelado/acinzentados, parâmetro considerado diagnóstico para a obtenção de uma espessura adequada das seções delgadas.

As análises micromorfológicas $\mathrm{e}$ as fotomicrografias foram realizadas em fotomicroscópio petrográfico Zeiss no laboratório de micromorfologia do Departamento 
de Ciência do Solo da ESALQ/USP, seguindo os critérios estabelecidos por Brewer (1976) e compilações realizadas por Castro (1989)

\subsubsection{Análises submicroscópicas e microanálise pontual}

Amostras indeformadas e selecionadas das glébulas plínticas e petroplínticas foram submetidas ao exame em microscópio eletrônico de varredura marca JEOL modelo JSM - T330A equipado com microssonda NORAN modelo TN 500 (Instituto Astronômico e Geofísico - IAG/USP/São Paulo). Para isso, amostras de aproximadamente $1 \mathrm{~cm}^{3}$ foram inicialmente nebulizadas com ouro e paládio e coladas em uma lâmina de vidro com cola de prata antes de serem introduzidas no tubo de vácuo do microscópio. A utilização da microanálise pontual foi apenas qualitativa, objetivando confirmar os minerais no interior das glébulas, os quais foram identificados pelo seu hábito quando observados no microscópio de varredura, bem como identificar outros elementos e minerais que as análises precedentes não detectaram. 


\section{RESULTADOS E DISCUSSÃO}

\subsection{Morfologia}

Foram estudados três perfis, identificados como P1, P2 e P3, todos localizados no sopé da vertente (Figura 7). Suas descrições morfológicas encontram-se no APÊNDICE 1 , sendo enfatizado neste capitulo apenas os principais atributos pertinentes à melhor caracterização e aos estudos de gênese dos diferentes horizonte nos perfis. Na Figura 9 estão reproduzidos os perfis P1, P2 e P3 e identificado todos os seus horizontes.

\subsubsection{Perfil P1}

\section{a) Solo, matriz e saprolito}

O perfil P1 (Figura 9) foi classificado como Plintossolo Pétrico em alto nível categórico (Camargo et al., 1987). Nele, observa-se dois exíguos horizontes acima dos horizontes ferricrete, ambos de textura areia franca. Sua cor varia de 7,5 YR 4/2 (bruno escuro) no horizonte A para 7,5 YR 4/4 (bruno escuro) no horizonte E. Já nos horizontes F1 e F2, sua matriz friável onde as glébulas estão inseridas, é de coloração vermelhoamarelado (5 YR 4/6). Dois horizontes ferricretes (F1 e F2) foram identificados, descritos e amostrados. No F1, há uma predominância de glébulas em relação a matriz, sendo que $80 \%$ (volume/volume) do horizonte é predominantemente glebular e os restantes 20\% representam o solo circundante às glébulas (matriz interglebular). No entanto, para o horizonte F2, a proporção de solo em relação às glébulas é maior. Uma relação de $40 \%$ glébulas $/ 60 \%$ solo foi encontrada, como pode ser inferido da Figura 10 , mostrando detalhes desses horizontes no perfil P1. Abaixo dos horizontes glebulares, o material saprolítico é progressivamente manchado em tons esbranquiçados a medida que 
se aprofunda no perfil. Colorações vermelhas (2,5 YR 4/8) no horizonte $\mathrm{Cr}$ são gradualmente substituidas por manchas cinzas (5YR 6/1) e amarela-avermelhadas (7,5 YR 6/6) nos horizontes Crg1 e Crg2, juntamente com o aumento da umidade e aprofundamento do perfil. A Figura 11 mostra o perfil oposto ao P1 na mesma trincheira, evidenciando os sinais de hidromorfismo na sua base. Nota-se por esta figura, a presença de macroporos arredondados com seu entorno esbranquiçado. Segundo Bouma (1983), nestas condições hidrológicas, os processos de redução podem ocorrer ao longo dos poros grandes onde o fluxo preferencial de água é responsável pela formação de goetita em suas paredes, podendo até removê-la quando condições adequadas de Eh são alcançadas, restando caolinita de coloração clara ao seu redor. A influência do movimento da água nessa porosidade é estendida a poucos milímetros do solo circundante aos poros, proporcionando a morfologia verificada na Figura 11. Uma outra interpretação é apresentada por Brewer (1976). Segundo o autor, quando a água movese nessa porosidade, as quais não estavam inicialmente saturadas e continham ar, o ferro mobilizado pode ser posteriormente oxidado a alguma distância dos poros como quasiferram, originando uma zona gleizada ao redor desses poros. No horizonte $\mathrm{Cr}$ notou-se colorações bruno-forte (7,5YR 5/6) contínuas na superficie dos fragmentos de arenito semidecomposto, entremeados a material friável. Comparando-se com a cor da matriz de F1 e F2 (5YR 4/8), o matiz mais amarelo na cerosidade sugerem a remoção de ferro no transporte das argilas da matriz dos horizontes $F$ e deposição na forma de cerosidade forte e abundante no horizonte abaixo, conforme sugestões de Lepsch et al. (1977b). Esse fato será detalhado mais adiante.

As classes texturais deste perfil são areia franca nos horizontes A e E, passando para franco argiloarenosa na matriz das glébulas e permanece com essa mesma textura no horizonte $\mathrm{Cr}$, sendo que a presença de cerosidade forte e abundante nesse último pode ser, em parte, devido à migração de argila. Isso é corroborado pela diminuição do conteúdo de argila em profundidade e drástica redução do grau de desenvolvimento e quantidade de cerosidade, passando para uma textura areia franca no $\mathrm{Crg} 2$, embora os processos de intemperismo da rocha e formação de solos possam originar minerais na 
fração argila. Talvez, a argiluviação seja o principal mecanismo de enriquecimento em argila do $\mathrm{Cr}$ em relação aos horizontes inferiores, fato que será discutido nas observações micromorfológicas.

A estrutura é composta de blocos subangulares e de fraco grau de desenvolvimento, embora de tamanho pequeno a médio no horizonte $\mathrm{A}$ e de médio a grande no horizonte $\mathrm{E}$. 

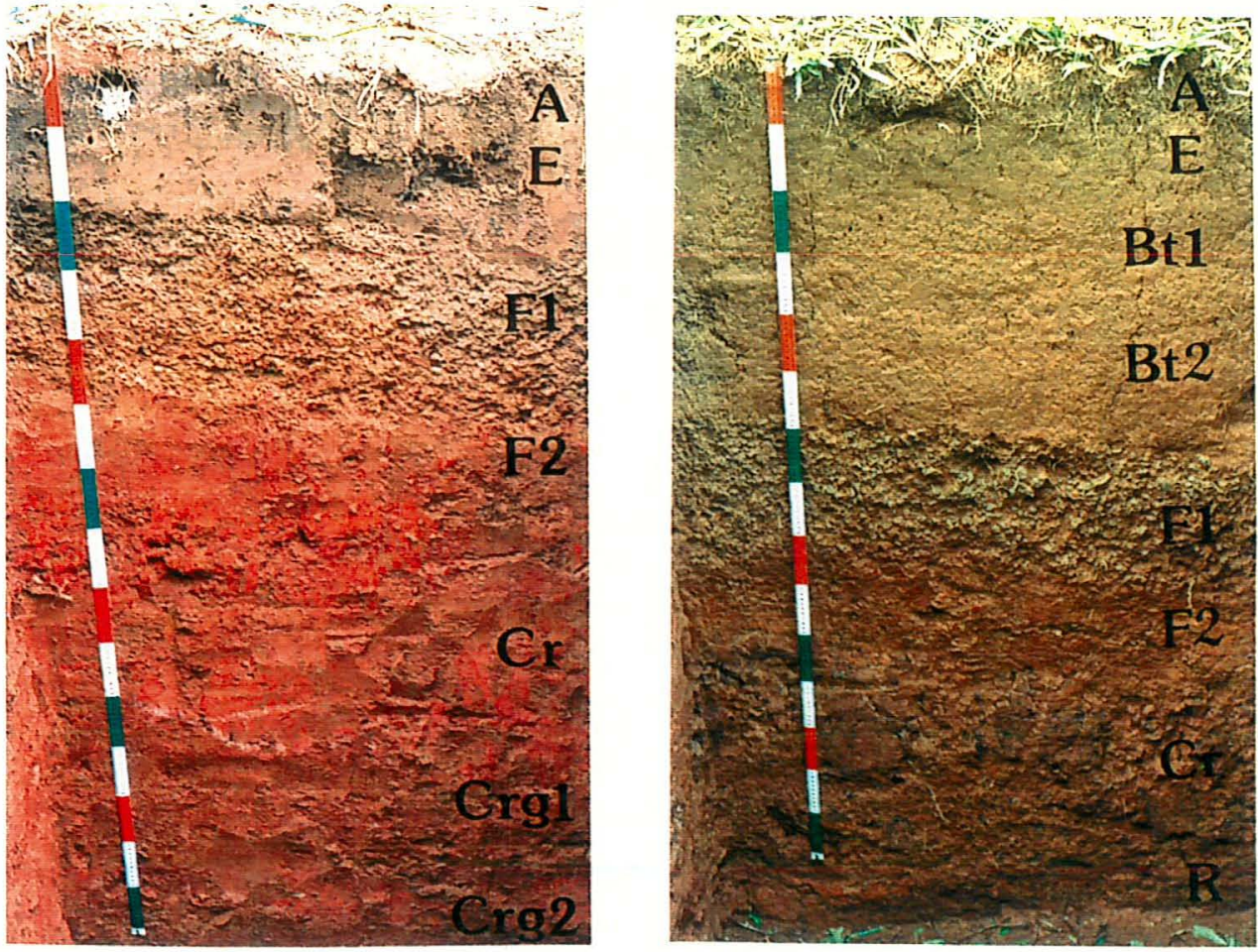

P1

P2

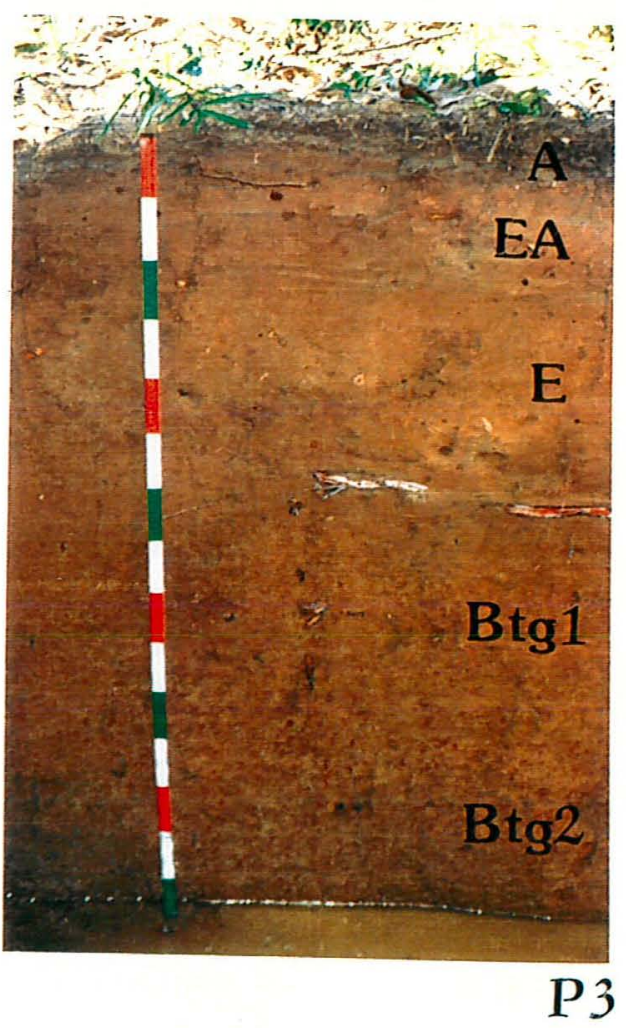

Figura 9. Fotografia dos perfis P1, P2 e P3 mostrando seus diferentes horizontes e camada. 


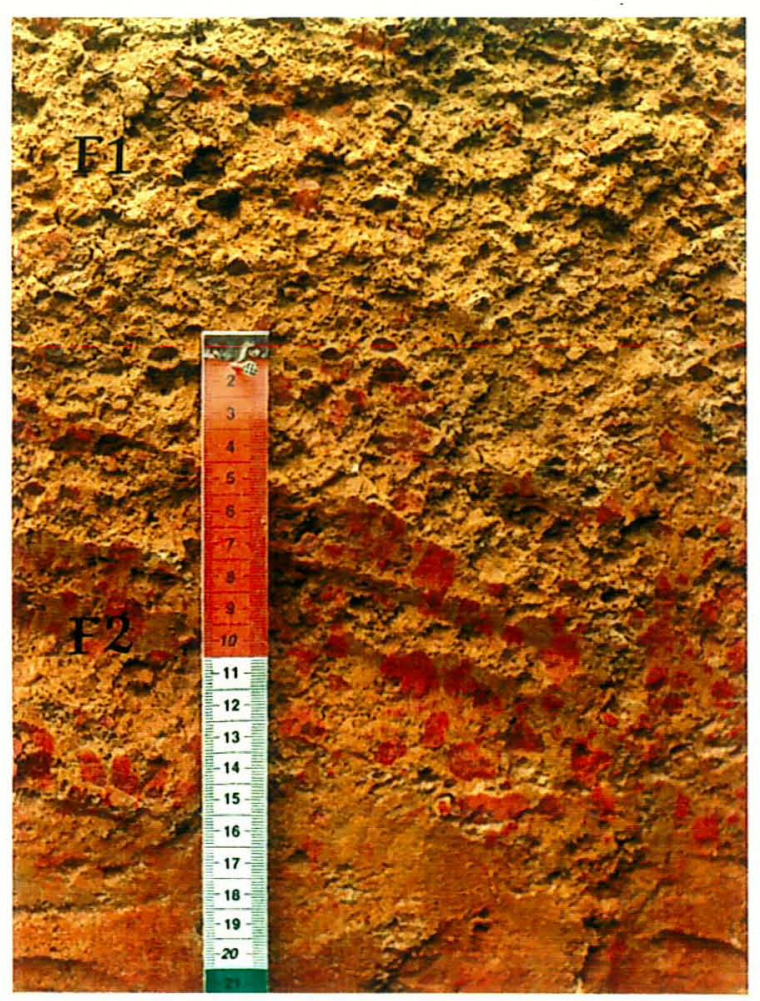

Figura 10. Detalhe da transição entre os horizontes F1 (petroplíntico) e F2 (plíntico) do perfil P1.

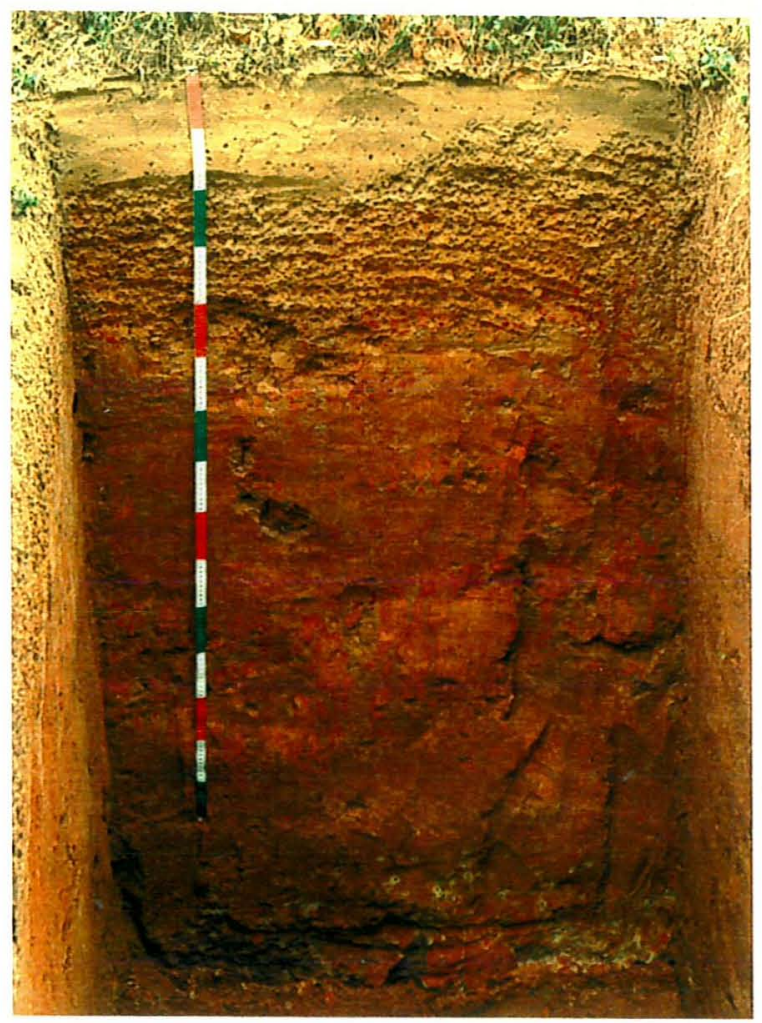

Figura 11. Perfil oposto ao P1 na trincheira. Notar sinais de hidromorfismo (alto valor e baixos croma) na base do perfil. 


\section{b) Glébulas}

Cinco propriedades macromorfológicas consideradas relevantes para a caracterização, diferenciação ou interpretação genética das amostras de ferricrete foram enfatizadas aqui. Essas propriedades possibilitaram a separação de dois horizontes ferricretes (F1 e F2) na descrição dos perfis P1 e P2, conforme sugestões de Lemos \& Santos (1996). A dureza do material, expresso pela sua resistência quando submetido a esforços com as mãos, é uma medida do grau de cimentação das glébulas e possibilita identificar seu estágio de desenvolvimento. A estrutura dos ferricretes reflete seu ambiente de formação e pode servir como uma ferramenta útil nas classificações genéticas destes materiais (Ibanga, 1980 e McFarlane, 1976). A cor é usada como uma medida do tipo e forma de ferro nos solos e também, juntamente à atributos como tamanho e quantidade, podem ser uma ferramenta útil na caracterização, distinção e interpretação genética entre fácies de ferricretes.

As glébulas do horizonte F1 foram caracterizadas pela elevada dureza, não possibilitando serem rompidas com as mãos. Essa dureza resulta em uma resistência dos ferricretes à penetração radicular, reduzindo a profundidade efetiva dos solos. Isso limita o desenvolvimento das plantas que se instalam acima desses horizontes, principalmente quando são maciços e afloram próximo à superficie. No entanto, muitas raizes conseguem se desenvolver entre as glébulas dos ferricrete pisolíticos ou nodulares, aprofundando-se e até mesmo nutrindo dessa porção friável do perfil, uma vez que o desmantelamento desses materiais podem contribuir para o rejuvenescimento dos solos (Debaveye et al., 1987), principalmente quando minerais primários facilmente decomponíveis são constituintes dos ferricretes. A presença comum de raizes fasciculadas nos horizontes saprolíticos e de uma abundante porosidade biológica com poros muito pequenos, evidenciam a facilidade, bem como a necessidade das raízes transporem o horizonte glebular em busca de água e nutrientes.

Ainda, com relação às glébulas do $F 1$, seus diâmetros variam desde milimétricas (4 mm) a centimétricas $(4 \mathrm{~cm})$, com tamanho médio de $1,5 \mathrm{~cm}$. Apresentam-se predominantemente com formas irregulares, algumas subarredondadas e mais raramente 
esféricas. Suas cores são vermelho-acinzentado (10 R 4/4), geralmente com um córtex milimétrico de cor vermelho-escuro-acizentado (10 R 3/6) e eventualmente bruno-forte (7,5 YR 5/8). Esses tons amarelados também estão freqüentemente presentes no interior das glébulas, dispersos em manchas irregulares. Englobam a classe dos ferricretes nodulares descritos por Bourman (1993), devido ao fato de não apresentarem bordas múltiplas e portanto, são nódulos na concepção de Brewer (1976) e Tardy (1993). Correspondem à petroplintita devido constituirem um material rígido (Curi et al., 1993), a fase esquelética da FAO (1994) pelo fato de material nodular não apresentar-se continuamente cimentado; bem como à definição de couraça, conforme apresentada por Tardy (1993).

As glébulas do horizonte $\mathrm{F} 2$ são muito duras quando secas e muito firmes quando úmidas, embora possam ser quebradas entre o polegar e o indicador. Suas dimensões variam desde $0,3 \mathrm{~mm}$ à $3,0 \mathrm{~cm}$ com diâmetro médio de $1,5 \mathrm{~cm}$. São de cores predominantemente vermelhas (2,5 YR 4/6), com uma borda milimétrica de coloração vermelho-acinzentado ( $10 \mathrm{R} 4 / 4)$, formas aproximadamente esféricas, geralmente irregulares e guardam as estruturas morfológicas do arenito. Segundo Roquin et al. (1990b) e Tardy \& Roquin (1992) esses ferricretes são imaturos e recebem a adjetivação de litodependentes. Correspondem a rocha ferricretizada de Bourman (1993) devido a preservação das estruturas da rocha de origem e também às feições ferruginosas identificadas como plintita (Daniels et al., 1978) pela menor dureza do material quando comparado as glébulas do horizonte $\mathrm{F} 1$.

\subsubsection{Perfil P2}

\section{a) Solo, matriz, saprolito e rocha}

O perfil P2 foi classificado como Podzólico Vermelho Amarelo Abrupto Pétrico ao nível categórico elevado, devido ao horizonte ferricrete situar-se abaixo de $50 \mathrm{~cm}$ de profundidade e não apresentar sinais de hidromorfismo nos horizontes acima do ferricrete (Camargo et al., 1987 e Empresa Brasileira de Pesquisa Agropecuária - EMBRAPA, 1988), conferindo prioridade ao horizonte textural como o principal critério diagnóstico 
na classificação deste solo. A proporção das glébulas em relação à matriz do horizonte F1 é semelhante ao perfil P1, com as glébulas ocupando $80 \%$ do volume do horizonte. No entanto, essa proporção é reduzida para o horizonte F2 comparando-se ao F1, perfazendo $60 \%$ do volume ocupado com glébulas. Essa relação, associada à estrutura e dureza das feições ferruginosas, foram os principais atributos morfológicos avaliados no campo para a separação e delimitação dos horizontes ferricretes. As determinações analiticas do horizonte F2 neste perfil foram realizadas em todo volume do horizonte, sem a separação das glébulas de sua matriz friável.

O perfil apresentou-se variando de 7,5 YR 4/2 (bruno) no horizonte A até 7,5 YR $4 / 4$ (bruno) no horizonte E. Já nos subhorizontes B e matriz do horizonte F1, a cor mantém-se vermelho-amarelado (5YR 4/6 no Bt1 e matriz; 5YR 4/8 no Bt2). No entanto, os matizes são mais vermelhos com o aumento da profundidade, com cores 2,5 YR 4/6 (vermelho) nos horizontes $\mathrm{F} 2, \mathrm{Cr}$ e camada $\mathrm{R}$, sugerindo maiores conteúdos de hematita na fração argila e/ou maior proporção relativa de hematita sobre goetita quando comparado aos horizontes superficiais. A Tabela 1 mostra a variação da cor em profundidade influenciada pela mineralogia dos óxidos de ferro. A cor do solo é muito semelhante a cor dos óxidos de ferro concentrados (Kämpf et al., 1988), indicando que a cor conferida pela hematita e goetita se sobrepõe à cor dos demais componentes do solo (Netto, 1996). Assim, nota-se pela tabela que há uma tendência de aumento do conteúdo de $\mathrm{Hm}$ (hematita) e $\mathrm{R}$ (hematita/hematita+goetita) em profundidade, com seus maiores valores nos horizontes ferricretes (F1-C e F2). Esse fato é acompanhado por uma bicromia entre os horizontes superficiais e inferiores, como mostrado acima, proporcionada pelo desenvolvimento de matizes cada vez mais vermelhos a medida que se aprofunda no perfil. Netto (1996) encontrou alta correlação entre os valores de Hm e $\mathrm{R}$ com o matiz para os solos vermelhos (matizes mais vermelhos que 7,5 YR), indicando que o teor e a proporção de hematita são variáveis influentes sobre a cor do solo. Essa tendência pode ser extrapolada aqui, sugerindo que matizes mais vermelhos em profundidade são conseqüências tanto de maiores conteúdos de hematita na fração argila, como da maior proporção relativa de Hm sobre Gt (goetita) quando comparamos aos 
horizontes superficiais. No entanto, manganês é outro componente com elevado poder pigmentante, conferindo colorações escuras aos solos quando estão segregados e precipitados (Oliveira et al., 1992 e Rhoton et al., 1993). No horizonte $\mathrm{Cr}$ e camada R observaram-se películas deste elemento ("coatings") com coloração preta (2,5 YR 2,5/0), revestindo tanto os fragmentos de saprolito como as fendas da rocha. A pequena proporção deste elemento no $\mathrm{Cr}$ e $\mathrm{R}$ quando comparado ao conteúdo de óxidos de ferro, como revelado pelos resultados analíticos, sugere uma pequena influência do manganês nas cores desses horizonte e camada quando analisamos as amostras homogeneizadas na condição de TFSA.

A presença de manganês no regolito dissociada ao ferro, freqüentemente está relacionada a curtos períodos de saturação. Nessas condições, somente o manganês é mobilizado e posteriormente oxidado quando seu potencial de oxidação é alcançado (Schwertmann \& Fanning, 1976 e Bouma, 1983). Assim, a presença do elemento em maior proporção nos horizonte $\mathrm{Cr}$ e camada $\mathrm{R}$ talvez esteja relacionada as condições atuais de hidratação da seqüência de solos estudada. Como mostrado anteriormente, o perfil P1 apresenta sinais de hidromorfismo na sua base. Esse fato, associado à presença de matizes mais amarelos (7,5 YR) num estreito limite à montante deste perfil, como verificado nas tradagens de campo, sugerem condições mais úmidas nesses locais quando comparados ao perfil P2. Este último perfil, manteve-se apenas esporadicamente com água no período chuvoso nas suas porções inferiores (últimos 20 centímetros), com o surgimento de uma morfologia típica de condições redutoras somente a maiores profundidades $(3,5 \mathrm{~m})$. Este padrão atual de distribuição hidrológica na seqüência estudada sugere a possibilidade de uma mobilização somente do manganês dos locais a montante do perfil P2, favorecidos por um curto período de saturação, como sugerido por Bouma (1983) e deposição do elemento numa estreita faixa do perfil P2 (Figura 9). A existência de macroporos planares e canais no horizonte saprolítico e rocha, tal como revelado na morfologia de campo e nas lâminas delgadas, associado à menor umidade no perfil, possibilitaram o preenchimento dessa porosidade com ar e estabelecimento de um potencial de oxidação elevado, adequado à concentração e precipitação de óxidos de 
manganês, conferindo assim, a existência de um "coating" enegrecido na superficie dos fragmentos saprolíticos e fendas da rocha, tal como foi observado no horizonte $\mathrm{Cr}$ e camada $\mathrm{R}$ do perfil $\mathrm{P} 2$.

Tabela 1. Características relacionadas à cor úmida (TFSA) e a mineralogia da fração argila para o perfil P2.

\begin{tabular}{|cccccc|}
\hline Horizonte & Profundidade & Cor úmida & R & Hm & Gt \\
\hline A & $0-10$ & 7,5 YR 4/2 & 15 & 1,7 & 9,6 \\
E & $10-26$ & 7,5 YR 4/4 & 21 & 2,9 & 11,0 \\
Bt1 & $26-38$ & 5 YR 4/6 & 19 & 5,4 & 22,9 \\
Bt2 & $38-60$ & 5 YR 4/8 & 26 & 13,3 & 37,8 \\
F1-S & $60-85$ & 5 YR 4/6 & 22 & 12,7 & 45,9 \\
F1-C & $60-85$ & 10 R 3/3 & 66 & 272,5 & 139,3 \\
F2 & $85-110$ & 2,5 YR 4/6 & 53 & 72,2 & 64,8 \\
Cr & $110-164$ & 2,5 YR 4/6 & 35 & 22,8 & 41,4 \\
R & $164-190$ & 2,5 YR 4/6 & 77 & 49,0 & 14,9 \\
\hline
\end{tabular}

F1-S: matriz interglebular do horizonte F1

F1-C: glébulas do horizonte F1

F2: $60 \%$ glébulas e 40\% matriz (amostra homogeneizada)

Hm e Gt: hematita e goetita na fração argila

$\mathrm{R}=\mathrm{Hm} /(\mathrm{Hm}+\mathrm{Gt}) \mathbf{x} 100$

A textura manteve-se como areia franca nos horizontes A e E, passando para franco argiloarenosa nos horizontes $\mathrm{Bt}$, matriz das glébulas do horizonte $\mathrm{F} 1$, horizonte $\mathrm{F} 2$ e $\mathrm{Cr}$, embora haja um aumento gradativo do conteúdo de argila em profundidade nestes horizontes. A variação textural deste perfil, principalmente para o solo acima do ferricrete, pode ser encarada, em parte, como um processo de e-iluviação, visto que filmes de argila foram observados no $\mathrm{Bt} 1, \mathrm{Bt} 2 \mathrm{e} \mathrm{Cr}$, morfologicamente expresso por uma cerosidade comum e moderada, além da presença do horizonte $\mathrm{E}$ (dos 10 aos $26 \mathrm{~cm}$ ), 
embora possamos considerar para os horizontes saproliticos, que a destruição da rocha e formação de solos é responsável pela gênese de minerais na fração argila, tal como comentado para o perfil P1. Isso é corroborado pela redução no conteúdo de argila e aumento da fração silte na rocha, passando para uma textura franco arenosa. Nela, os minerais primários facilmente decomponiveis estão preservados na fração areia, os quais são progressivamente decompostos com o avanço do intemperismo na formação do saprolito e solo, originando silte nos estágios iniciais que podem evoluir para minerais de argila com desenvolvimento do perfil (Dechen, 1979 e Dechen et al., 1994).

Quanto à estrutura, manteve-se composta de blocos subangulares médios e de fraco grau de desenvolvimento nos horizontes A e E e a partir deles, blocos subangulares grande e de grau moderado. O aumento significativo do teor de argila nos horizontes argílicos pode ser responsabilizado por tal fato.

Neste perfil, o horizonte A pode ser considerado como um epipedon ócrico devidos às suas cores claras, enquanto que o $\mathrm{B}$ como um argílico, pelo gradiente textural e cerosidade moderada (Soil Survey Staff, 1975).

\section{b) Glébulas}

As glébulas do horizonte F1 apresentavam elevada dureza, à semelhança ao perfil P1, não sendo rompidas com as mãos. No entanto, divergem destas pelo tamanho, cor e tipo. Suas dimensões vão desde 0,3 a $10 \mathrm{~cm}$ de diâmetro, com tamanho médio de $2,3 \mathrm{~cm}$. Apresentam formas diversas, predominantemente irregulares e eventualmente subarredondadas e algumas descritas aqui como de estrutura "ruiniforme" devido à aparência de material destruído, em ruínas. Essas últimas, são as maiores glébulas do horizonte ferricrete, perfazem $10 \%$ do volume deste horizonte e assemelham-se a um agrupamento ou coesão entre indivíduos menores, pois consegue-se, com esforço moderado, individualizar pequenos nódulos na sua periferia ou mesmo identificar nesta massa glebular, pequenos volumes com a mesma morfologia das glébulas individuais e de menores tamanho, porém estão fortemente aderidas. A coesão das glébulas é considerada 
por McFarlane (1976) como o principal mecanismo na gênese de couraças ferruginosas maciças.

Com relação às cores, nas amostras indeformadas e secas elas distribuem-se de maneira desuniforme entre as glébulas, no entanto, predominam colorações bruno-forte (7,5 YR 5/8) e vermelho-escuro-acizentado (10 R 3/3) em proporções semelhantes, com córtex vermelho-escuro-acinzentado (10 $\mathrm{R} 3 / 3)$, divergindo das glébulas do perfil anterior principalmente pelo maior ocorrência de manchas com matizes mais amarelos (7,5 YR 5/8). Algumas mostram cores brancas (10 YR 8/1) no interior, sugerindo presença de caulinita. Também, poucas e raras glébulas apresentam-se com segregações de manganês no seu interior, caracterizados pela coloração preta $(2,5$ YR 2,5/0) distribuídas como manchas no seu centro. Muitos trabalhos tem identificado a presença desse elemento nos nódulos e concreções de ferro (Beauvais \& Colin, 1993; Beauvais \& Roquin, 1996; Beauvais et al., 1990; Childs, 1975, Roquin, 1990; Schwarz, 1994 e Sidhu et al., 1977), e freqüentemente concentram-se como películas em torno das glébulas, ou ainda como veios ou manchas enegrecidas no seu interior (Taylor \& MacKenzie, 1966).

A presença do manganês no interior de algumas glébulas sugerem que, nos estágios iniciais de sua formação, este elemento estava disponivel, juntamente com ferro (Schwertmann \& Fanning, 1976). Como manganês é mais solúvel e móvel que o ferro, no entanto requer maiores potenciais de oxidação para precipitar (McKenzie, 1989), esperase que a deposição deste elemento ocorra nos estágios finais de formação das glébulas, quando o nivel do lençol freático está definitivamente mais baixo e maiores potenciais de oxidação prevalecem, principalmente nos poros planares e canais de grande tamanho preferencialmente preenchidos com ar (Bouma, 1983) e ocorrentes nos fragmentos de rocha parcialmente decompostos (saprolito), como verificado atualmente. Uma posterior remobilização do ferro, principalmente provindo das próprias glébulas ferruginosas acima e ainda pouco cristalinizadas, favorece a precipitação do elemento nos locais de deposição de manganês, uma vez que o ferro tende a se depositar nos sítios onde manganês já existe (McKenzie, 1989), principalmente nos poros planares e canais, como citado acima, onde maiores potenciais oxidação prevalecem, embora o restante do perfil 
ainda permaneça em condições adequadas de Eh para remobilização do ferro. Devido ao pouco conteúdo de manganês em relação ao ferro no ambiente, como revelado nos resultados analiticos, uma pequena e interrupta deposição de manganês é esperada. Assim, apenas ferro é posteriormente mobilizado e precipitado nos poros planares e canais ao redor das precipitações iniciais de manganês e ferro, as quais atuaram como núcleo para as deposições ferruginosas sucessivas, encerrando o manganês no interior das glébulas ferruginosas, principalmente nas formas minerais de birnessita e litioporita (Schwertmann \& Fanning, 1976), até evoluírem para a morfologia hoje encontrada.

Uma vez que manganês precipita posteriormente ao ferro devido ao seu elevado potencial de oxidação, como é encontrado nos poros planares e canais do material saprolítico, sua deposição é verificada abaixo do horizonte ferricrete glebular, fato que condicionaria a formação destas glébulas manganíferas também abaixo e próximo ao horizonte ferricrete. Isso é verificado na área, no entanto, processos posteriores de pedobioturbação podem misturar esses diferentes tipos de glébulas, distribuindo-os aleatoriamente no horizonte ferricrete. De acordo com as suposições acima, as glébulas mais manganiferas são as mais recentes do horizonte petroplíntico.

A semelhança do perfil P1, essas glébulas pertencem à classe dos ferricretes nodulares descritos por Bourman (1993) e caracterizam nódulos na concepção de Brewer (1976) e Tardy (1993). Correspondem à petroplintita devido constituírem um material rígido (Curi et al., 1993) e a fase esquelética da FAO (1994) pelo fato de material nodular não apresentar-se continuamente cimentado. A Figura 12 caracteriza as diferentes glébulas encontradas no horizonte $\mathrm{F} 1$, possibilitando uma visualização de suas cores predominantes e estruturas.

O horizonte F2 é caracterizado pela presença de glébulas que guardam nitidamente as estruturas da rocha de origem (Figura 13). Apresentam formas diversas, predominantemente irregulares, algumas com tendências poliédricas cúbicas, assemelhando-se aos fragmentos de saprolito semidecomposto impregnados com ferro e identificados por Bourman (1993) como rocha ferricretizada. Apresentam-se muito duras quando secas e muito firmes quando úmidas, podendo ser quebradas com as mãos à 
semelhança ao perfil P1, no entanto são maiores. Suas dimensões variam desde 0,6 a 7 $\mathrm{cm}$ com diâmetro médio de $3 \mathrm{~cm}$. Quanto às cores, assemelham-se ás glébulas do horizonte F2 no perfil $\mathrm{P} 1$, com a dominância de vermelho $(2,5 \mathrm{YR} 4 / 8)$, porém, foram observadas cores bruno-forte $(7,5$ YR 5/6) em maior abundância, sugerindo predominância de goetita. Também, a presença de um córtex vermelho-escuroacinzentado (10R 3/3) é observado na maioria das glébulas deste horizonte, constituindo sua porção mais endurecida e possivelmente composta de hematita bem cristalinizada. A semelhança às glébulas de F2 do perfil P2, são classificadas como plintita pela menor dureza do material quando comparado as glébulas do horizonte F1. No entanto, são firmes o suficiente para preservarem sua estrutura quando imersos em água sob agitação suave (Wood \& Perkins, 1976).

Comparado-se as glébulas dos perfis P1 e P2 na Tabela 2, observa-se matizes mais vermelhos (10 YR) nas amostras indeformadas do material petroplíntico (F1-C dos perfis P1 e P2) em relação à plintita (cor 2,5 YR no F2-C do perfil P1), devido tanto aos maiores conteúdos de $\mathrm{Hm}$ no primeiro como aos maiores valores de $\mathrm{R}$ (Netto, 1996). Quando são analisadas as cores secas das amostras na TFSA, estas sugerem que os menores valores nas glébulas F1-C em relação as amostras plínticas, também são devido ao maior conteúdo de hematita nestas amostras, como sugerido por Netto (1996). Esse autor, estudando a capacidade preditiva da cor para diferentes tipos de solos, afirma que a presença da hematita, além de conferir matizes mais vermelhos ao solo, o torna mais escuro, ou seja, com baixo valor. Nota-se também que, a petroplintita do perfil P2 apresenta matizes mais vermelhos $(10 \mathrm{R})$ e menores cromas quando comparamos as amostras úmidas das frações TFSA em relação ao material similar do perfil P1 (2,5 YR). Possivelmente as mesmas interpretações sugeridas acima são responsáveis por este comportamento, ou seja, o teor e a proporção de hematita conferem colorações mais vermelhas, bem como baixos cromas ao materiais analisados úmidos. Portanto, observase pela Tabela 2 que as petroplintitas são predominantemente hematíticas, enquanto nos componentes plínticos predominam goetita. 
Quanto a ocorrência de glébulas nos horizontes supra e subjacentes ao horizonte glebular, estas estão presentes nos horizontes A e E nas formas irregulares de pequeno tamanho (inferior a $0,3 \mathrm{~cm}$ ) para o perfil $\mathrm{P} 1$, perfazendo menos que $1 \%$ do horizonte (volume/volume). Essa morfologia também é verificada para o perfil P2, divergindo do primeiro por um sutil aumento no tamanho e conteúdo das glébulas com a profundidade, embora seu valores no horizonte Bt2 não ultrapassem $2 \%$ da área e ocorra uma transição abrupta entre este horizonte e o horizonte ferricrete. Também, glébulas diminutas, raras, porém irregulares são constituintes dos horizontes saprolíticos do perfil P2. A sugestão de McFarlane (1976) de que glébulas de lençol são formadas no saprolito e apresentam um padrão de distribuição abaixo do horizonte ferricrete caracterizado pela diminuição de sua freqüência e aumento da irregularidade das formas com a profundidade, até elas graduarem para mosqueados, parece ser reproduzida aqui. Embora mosqueados estejam ausentes nestes perfis, a morfologia apresentada pelo horizonte plíntico (F2) com a presença de plintita de formas irregulares e em menores proporções em relação ao horizonte petroplíntico (F1), sugerem uma morfologia típica de ferricretes formadas no saprolito e que correspondem aos "pisolitos de lençol", segundo McFarlane (1976, p.74). A localização no terço inferior da vertente é um forte e talvez, o principal argumento que corrobora a origem desses ferricretes provenientes da segregação e precipitação de ferro no estreito limite de oscilação do lençol, desde que a origem desses materiais seja in situ. Segundo a autora, nódulos pedogenéticos são originados no solo e aumentam em freqüência em direção a base do perfil com sua máxima expressão no horizonte ferricrete. Esse fato é praticamente inexpressivo na área estudada, tal como citado anteriormente, mesmo porque a existência de pequenas e poucas glébulas nos horizontes suprajacentes ao horizonte ferricrete podem ser oriundas de processos outros que não o desenvolvimento pedogenético das glébulas no solo, com a formação da morfologia hoje encontrada nos perfis. A queda natural de árvores de pequeno e médio porte por exemplo, devido às suas raizes estarem confinadas aos horizontes superficiais acima do horizonte ferricrete, é sugerido aqui como um processo capaz de remover pequenas 
glébulas da superficie dos horizontes ferricretes, intimamente em contato com suas raizes e, através da bioturbação, incorporá-las ao solum.

Outras características morfológicas evidenciam a designação de ferricrete de lençol aos materiais aqui estudados. Comparando-se a um perfil típico (McFarlane, 1976 e McFarlane, 1983), o pequeno desenvolvimento dos perfis estudados sugerem uma origem de lençol aos ferricretes, como comentam McFarlane (1976) e McFarlane (1983) e Wright et al. (1992). Também, concentrações de ferro nos solos originando os ferricretes pedogenéticos são tipicamente complexos, tanto estruturalmente como composicionalmente (Tardy \& Nahon, 1985 e Milnes et al., 1985). Porém, as glébulas aqui são simples em estrutura, como descritas anteriormente, corroborando novamente sua origem associada à oscilação do lençol. São os ditos ferricretes de lençol, como sugerem Bourman et al. (1987) e Wright et al. (1992).

Tabela 2. Características relacionadas à cor e a mineralogia das glébulas para os perfis P1 e P2.

\begin{tabular}{|c|c|c|c|c|c|c|c|}
\hline \multirow[t]{2}{*}{ Horizonte } & \multirow{2}{*}{$\begin{array}{l}\text { Profund. } \\
\qquad(\mathrm{cm})\end{array}$} & \multirow{2}{*}{$\begin{array}{c}\text { Cores }^{2} \\
\text { Seca }\end{array}$} & \multicolumn{2}{|c|}{ Cor TFSA } & \multirow[t]{2}{*}{$\mathrm{R}^{\mathrm{b}}$} & \multirow[t]{2}{*}{$\mathrm{Hm}^{\mathrm{c}}$} & \multirow[t]{2}{*}{$\mathrm{Gt}^{\mathrm{c}}$} \\
\hline & & & seca & úmida & & & \\
\hline \multirow{2}{*}{\multicolumn{2}{|c|}{ Perfil P1 }} & & & & -.--\%--- & \multicolumn{2}{|c|}{$-{ }_{-1}$} \\
\hline & & & & & & & \\
\hline \multirow[t]{2}{*}{$\mathrm{F} 1-\mathrm{C}$} & $25-45$ & $10 \mathrm{R} 4 / 4 \mathrm{e}$ & $2,5 \mathrm{YR}$ & $2,5 \mathrm{YR}$ & 57 & 195,9 & 148,4 \\
\hline & & 7,5YR 5/6 & $3 / 6$ & $3 / 4$ & & & \\
\hline \multirow[t]{2}{*}{ F2-C } & $45-55$ & $2,5 \mathrm{YR} 4 / 6$ & $2,5 \mathrm{YR}$ & $2,5 \mathrm{YR}$ & 45 & 106,2 & 131,4 \\
\hline & & & $4 / 6$ & $4 / 4$ & & & \\
\hline \multicolumn{8}{|c|}{ Perfil P2 } \\
\hline \multirow[t]{2}{*}{ F1-C } & $60-85$ & $10 \mathrm{R} 3 / 3 \mathrm{e}$ & $2,5 \mathrm{YR}$ & $10 \mathrm{R}$ & 66 & 272,5 & 139,3 \\
\hline & & 7,5YR 5/8 & $3 / 4$ & $3 / 3$ & & & \\
\hline
\end{tabular}

${ }^{2}$ Cores predominantes das amostras secas e indeformadas

${ }^{b} \mathrm{R}=\mathrm{Hm} /(\mathrm{Hm}+\mathrm{Gt})$

'Hm e Gt: hematita e goetita na fração argila 
A
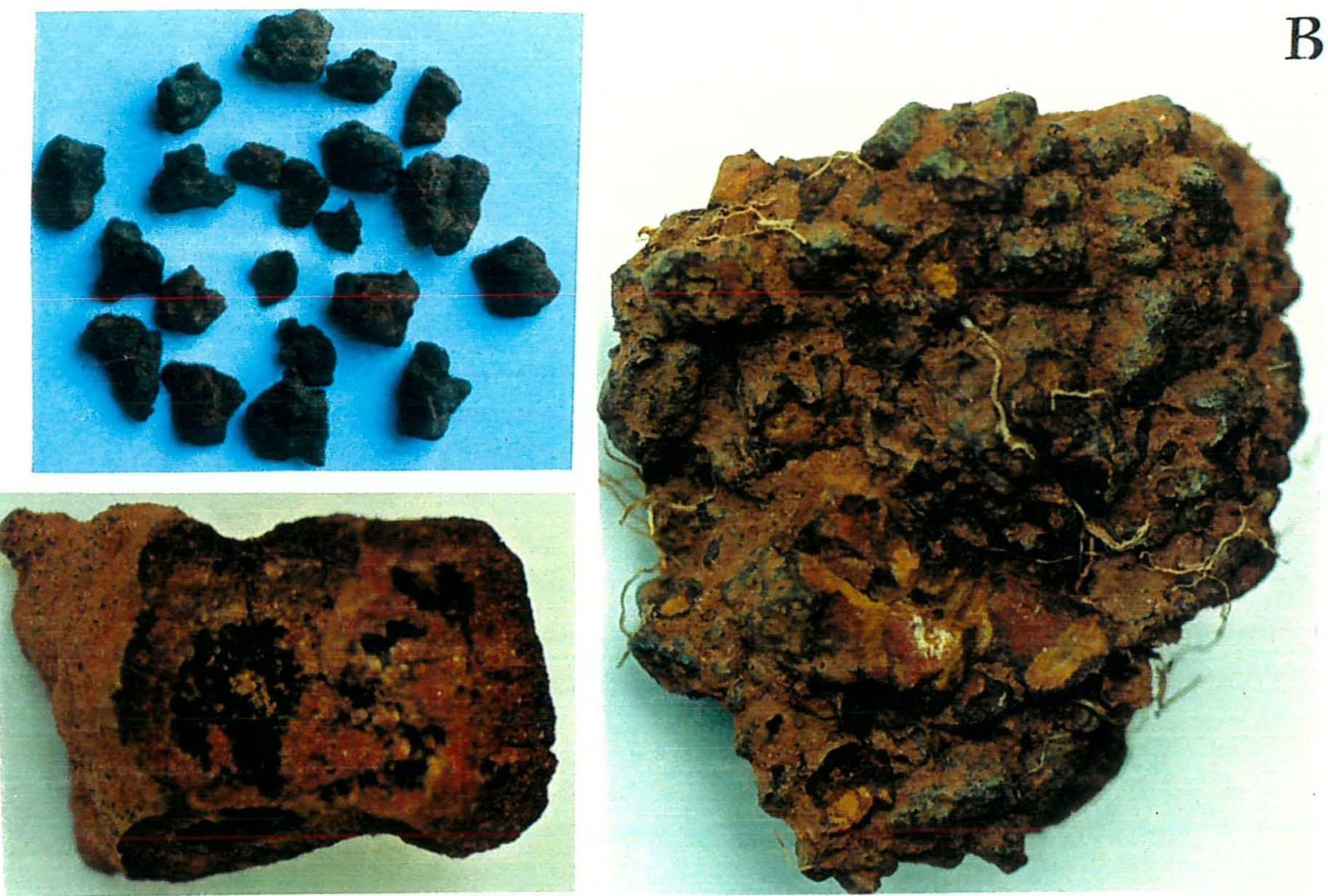

Figura 12. Glébulas petroplínticas do perfil P2: A) glébulas irregulares $(1,5 \mathrm{~cm}$ de diâmetro) predominantes no horizonte petroplíntico (Fl); B) Glébulas "ruiniformes" (10 cm); C) Nódulo com seu interior enegrecido devido à presença de manganês ( $3 \mathrm{~cm}$ no maior eixo).

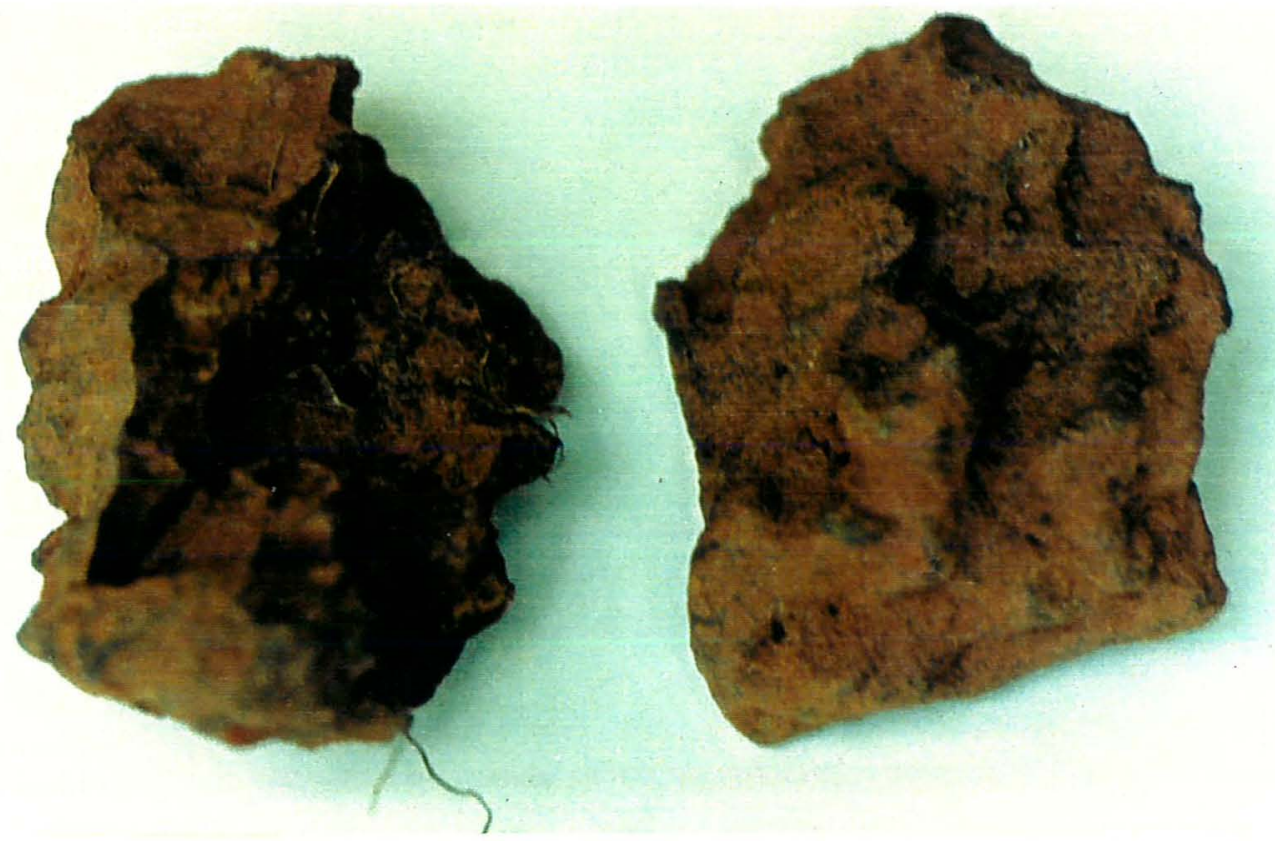

Figura 13. Glćbulas plínticas do perfil P2. Notar formas poliédricas, assemellando-sc aos fragmentos do saprolito. Diâmetro: $4 \mathrm{~cm}$. 


\subsubsection{Perfil P3}

Este perfil foi classificado como Podzólico Vermelho Amarelo Abrupto moderadamente drenado ao nível categórico mais elevado (EMBRAPA, 1988). Nele, mosqueados foram as únicas feições ferruginosas encontradas, aumentando em tamanho e quantidade a medida que se aprofunda no perfil. Não podem ser considerados plintita no horizonte Btg2 pelo fato de não estarem coerentes o bastante para serem separados do solo circundante (Daniels et al., 1978). Para o horizonte Btgl, o não enquadramento dos agregados em plintita é devido a esses materiais desfazerem-se totalmente quando imersos em água sob agitação suave (Wood \& Perkins, 1976)

Apresenta coloração variando de bruno-escuro (7,5 YR 3/2) no horizonte A até bruno nos horizontes EA (7,5 YR 4/4) e E (7,5 YR 5/4). Já nos subhorizontes Btg, sua cor predominante é vermelho-amarelado (5YR 4/8) no Btg1, secundariamente brunoamarelado (10YR 5/4), com pequenas manchas bruno-acinzentadas (10 YR 5/2) e mosqueados vermelhos $(2,5$ YR 4/8) distribuídos em $20 \%$ da área total do horizonte. Para o Btg2, os mosqueados são também avermelhados (2,5 YR 4/6) e perfazem $40 \%$ da área do horizonte, com as colorações de fundo variegadas compostas de bruno (7,5 YR $5 / 4$, úmido) e bruno-acinzentado ( 10 YR 5/2, úmido).

O fenômeno de mosqueamento é amplamente usado como indicador do regime de umidade dos solos (Bouma, 1983) e sua gênese está relacionada a ciclos sucessivos de umidecimento e secagem que encorajam a oxidação de compostos de ferro e a formação de goetita e hematita cristalinas (Thomas, 1994). Este perfil encontra-se intermitentemente submerso, com o nível do lençol próximo à superficie na estação chuvosa e praticamente ausente durante parte da estação seca, favorecendo ciclos de umidecimento e secagem, embora permaneça permanentemente úmido nos horizontes inferiores durante todo o ano. Assim, nestas condições hidrológicas, o ferro é localmente mobilizado e lixiviado das áreas aqui representadas pelo alto valor e baixo croma (10 YR $5 / 2$ ), principalmente associado aos poros grandes, concentrando-se na forma de mosqueados predominantemente goetíticos no interior dos pedes, dominados por microporos onde o potencial de oxidação do ferro é alcançado (Nahon, 1986; Nahon, 
1991; Tardy \& Nahon, 1985 e Bouma, 1983). Períodos alternantes de saturação por ação do lençol freático ocorrem neste perfil, possibilitando a segregação dos óxidos de ferro na estação úmida e sua precipitação e cristalinização na estação seca.

A maior ocorrência dos mosqueados no horizonte Btg2, bem como sua menor coerência em relação ao solo circundante, podem ser interpretados aqui pela existência de menores potenciais de oxidação durante periodos de tempo mais curtos neste horizonte em relação ao $\mathrm{Bt1}$, promovendo assim, maior mobilização do ferro para o Btg2 e maior cristalinização dos óxidos de ferro para o Btg1. Esses processos são portanto atuais e evolvem a formação simultânea de mosqueados por todo o perfil.

A textura neste perfil é areia franca nos horizontes A, EA e E, passando para franco argiloarenosa nos horizontes texturais, fato também foi verificado no perfil P2.

A estrutura, que se mostrou granular no horizonte $A$ passou a blocos subangulares nos horizontes EA, E e horizontes Btg1 e Btg2, no entanto com maior grau de desenvolvimento nestes dois últimos. $O$ maior conteúdo de argila também é responsável pela melhor estruturação dos horizontes argílicos.

A cerosidade começou a manifestar-se no horizonte Btg1 como moderada e comum, passando no Btg2 para fraca e pouco. Elas estão predominantemente associadas a parede dos poros maiores e localizadas principalmente nos matizes mais vermelhos dos horizontes.

As evidências morfológicas e a posição de sopé dos ferricretes encontrados em toda área da Estação Experimental de Pindorama (Figura do Mapa de Solos) e arredores, evidenciam sua origem de lençol e sugerem uma formação essencialmente in situ. Essa última suposição está embasada principalmente na ausência dessas feições nas posições mais elevadas da paisagem. No entanto, durante as observações tanto macromorfológicas dos perfis, como nas tradagens da seqüência estudada seguindo procedimentos de análise estrutural, algumas questões foram detectadas e indagadas, dentre as quais podemos ressaltar: 
1- Qual a relação entre o solo acima ao horizonte ferricrete e este, ou seja, há uma filiação entre todos os horizontes do perfil ferricrete de modo que sua origem é in situ, através de uma evolução pedogenética?

2- Qual a relação entre os horizontes petroplíntico (F1) e plíntico (F2)? Se estão em diferentes estágios evolutivos ou idades, então quem se formou primeiro e quais os diferentes mecanismos envolvidos na gênese desses materiais?

3- Qual a origem do ferro para a formação dos ferricretes? São realmente ferricretes de lençol conforme evidências morfológicas e portanto são essencialmente alóctones ou há alguma participação dos mecanismos de natureza residual?

4- No perfil P3, onde mosqueados foram as únicas feições ferruginosas, os processos atuais envolvidos na sua gênese teriam sido as etapas iniciais no desenvolvimento dos ferricretes como encontramos hoje?

5- Qual a origem das glébulas ditas "ruiniformes" (Figura 12)? São realmente formadas através de uma fusão das glébulas menores? Quais os mecanismos envolvidos na sua gênese e das demais glébulas?

6- Como os horizontes ferricretes evoluiram para formar sua atual configuração lateral na seqüência estudada?

Uma vez que ferricretes são os produtos integrados das mudanças pedológicas, geológicas e regimes hidrológicos que se processam durante a evolução da paisagem (McFarlane, 1983, Bourman et al., 1987 e Beauvais \& Roquin, 1996), todas essas indagações apontadas acima enfocam e encontram suas respostas nos estudos da gênese dos horizontes ferricretes, com suas feições ferruginosas e matriz friável. Também, como comentam Blume \& Schwertmann (1969), tanto o ferro como o alumínio e manganês, em virtude de serem bastante influenciados pelos processos de formação dos solos, bem como serem componentes dos óxidos e hidróxidos, indicam o tipo, a direção e extensão dos processos pedogenéticos. Assim, elucidar os mecanismos envolvidos na gênese dos 
ferricretes é elucidar os principais processos ocorridos nesta porção da paisagem sob domínio das feições ferruginosas.

A seguir, evidências físicas, químicas, mineralógicas, micromorfológicas e submicroscópicas serão agrupadas e integradas dentro do possível, objetivando elucidar os diferentes mecanismos envolvidos na gênese desses materiais ferruginosos endurecidos, em resposta aos questionamentos acima. Também, a caracterização dos ferricretes como componente do regolito proporciona um melhor entendimento da evolução dos sistemas de intemperismo onde esses materiais ocorrem (Beauvais \& Colin, 1993) e por isso, será enfatizada nos itens seguintes; assim como a caracterização e elucidação dos diversos mecanismos atuantes na gênese dos diversos horizontes nos perfis estudados, pois como comenta McFarlane (1976, p.53), o estudo dos perfis onde os ferricretes ocorrem "possibilita eliminar algumas das menos fundamentadas especulações concernentes a gênese desses materiais". 


\subsection{Evidências físicas}

\subsubsection{Granulometria}

A análise granulométrica dos perfis P1, P2 e P3 encontra-se na Tabela 3. Nota-se teores relativamente altos de areia $(44 \%$ a $84 \%)$, bem como baixos a moderados conteúdos de silte $(4 \%$ a $30 \%)$ e argila $(7 \%$ a $34 \%)$, todos condicionados tanto pela litologia como por diferentes processos pedogenéticos atuantes nos perfis, como veremos adiante. A distribuição granulométrica das glébulas, embora mostrada na Tabela 3 , é fruto de artefato. O preparo dessas amostras foram realizadas em moinho, possibilitando a desagregação das frações mais grosseiras para mais finas. Esse fato, associado a ineficiência do agente dispersante utilizado na metodologia granulométrica, devido ao elevado conteúdo, cristalinidade e conseqüentemente elevado poder cimentante dos óxidos de ferro das glébulas, interferem na eficiência e representatividade dessa metodologia, e por isso, devem ser consideradas com cautela. No entanto, confrontando essa informação com as observações micromorfológicas, podemos inferir que as glébulas apresentam aproximadamente $65 \%$ de areia total.

Considerando-se o Perfil 1, os maiores teores de argila foram encontrados na matriz do horizonte F1 (F1-S com 32\%) e horizontes Cr (30\%) e Crgl (25\%). Observase uma redução no conteúdo de argila com a profundidade para os horizontes saprolíticos, chegando a $12 \%$ no $\mathrm{Crg} 2$, que associado ao aumento no conteúdo de areia total (passa de 54\% no $\mathrm{Cr}$ para $75 \%$ no $\mathrm{Crg} 2$ ) e manutenção dos conteúdos de silte nos horizontes $\mathrm{Crg} 1(11 \%)$ e $\mathrm{Crg} 2(12 \%)$, sugerem um efeito combinado de dois mecanismos. Primeiro, o saprolito pode estar fornecendo tanto argila litoherdada como proveniente da degradação de seus minerais primários facilmente decomponíveis e presentes na fração areia. Em segundo lugar e como citamos anteriormente, a argiluviação possivelmente é um mecanismo consistente nesse aumento do conteúdo de argila, uma vez que detectou-se no campo uma cerosidade forte e abundante no horizonte $\mathrm{Cr}$, reduzindo seu grau de desenvolvimento e quantidade com a profundidade. A significativa presença de feldspatos do grupo dos plagiocásios potássicos foi evidenciado por Lepsch et al. (1978) em estudo mineralógico realizado na Estação Experimental de 
Pindorama. Segundo os autores, esses seriam os únicos minerais da fração areia considerados como facilmente decomponiveis e que poderiam originar minerais de argila, reforçando assim, a idéia da origem da fração argila com a decomposição do saprolito. Análises mineralógicas do presente estudo confirmam esses resultados. $O$ segundo mecanismo, a argiluviação, tem seu respaldo nas análises macro e micromorfológicas, mineralógicas e dissoluções seletivas.

A relação $F_{d}$ /argila é sugerido por Lepsch et al. (1977b) como um indicativo da desestabilização dos agregados pela liberação de ferro e colocação da argila em suspensão. Para o perfil P1 e desconsiderando seus horizontes superficiais, observa-se pela Tabela 3 uma redução dessa relação com a profundidade, passando de 0,15 no F1-S para 0,12 no $\mathrm{Cr}$ e 0,08 no $\mathrm{Crg}$. Assim, esses resultados podem também ser interpretados aqui como indicação de uma migração preferencial das argilas com menores conteúdos de sexquióxidos, eluviados da matriz do horizonte ferricrete (F1-S) para os horizontes inferiores, novamente sugerindo a influência da argiluviação no aumento do conteúdo de argila com a profundidade, bem como o constante suprimento de plasma ferruginoso (maior Fd) ao horizonte ferricrete pela degradação das glébulas, passível de sofrer eluviação. Ainda, segundo os autores, a redução e remoção dos óxidos de ferro com a desestabilização dos agregados é conseqüência do aumento do conteúdo de umidade acima do Bt quando a precipitação excede a condutividade hidráulica. Também, podemos argumentar para o perfil P1 que a presença predominante de goetita na matriz friável dos horizontes glebulares, como revelaram as análises mineralógicas (Tabela 1), sugerem maior umidade nessa porção do perfil, mesmo porque o desmantelamento das glébulas, como comentado anteriormente estar ocorrendo, é condicionado por processos de hidratação e redução do ferro, os quais levam à transformação da hematita em goetita, bem como são responsáveis pela lixiviação do ferro (Beauvais e Tardy, 1993). Portanto, as evidências acima convergem para o estabelecimento de condições adequadas à mobilização do ferro da matriz do horizonte $F$, e por isso promovem também condições adequadas à migração preferencial de partículas de argila que contém menores quantidades de sesquióxidos de ferro, como afirmam Lepsch et al. (1977b), favorecendo 
assim, a evidência de que a argiluviação é um mecanismo consistente no fornecimento de argila aos horizontes saproliticos, principalmente ao $\mathrm{Cr}$. Também, a presença de cerosidade nesse horizonte e com matizes mais amarelos (7,5 YR) em relação ao solo circundante às glébulas (5YR), é outro argumento sugestivo à essa migração preferencial de argila dos horizontes $\mathrm{F}$ e com menores conteúdos de ferro.

As mesmas interpretações podem ser inferidas para o perfil P2, embora os maiores conteúdos de silte na rocha $(R)$, a presença de menor quantidade e grau de desenvolvimento da cerosidade no $\mathrm{Cr}$ e a distribuição crescente da relação $F_{d} /$ argila com a profundidade (Tabela 3), todos em relação ao perfil P1, sugerem uma predominância do mecanismo de degradação dos minerais da fração areia da rocha e formação de argilas. A rocha $(\mathrm{R})$, fornece silte $(30 \%)$ como material de intemperismo que resultará na fração argila do saprolito e solo, como interpretado por Dechen (1979) e Dechen et al. (1994). Verifica-se ainda, que o teor de argila é baixo no horizonte A (8\%) e E (10\%), teor este que aumentou bruscamente no horizonte Bt1 (25\%) e Bt2 (26\%) sugerindo, desse modo, o processo de iluviação que ocorre nesse horizonte, como revelado nas seções delgadas, embora mecanismos deposicionais (colúvio) e remoção lateral das argilas, são também responsáveis pela diferenciação textural entre os horizontes arenosos superficiais e os horizontes argilicos.

Esses variados mecanismos de formação dos horizontes acima do horizonte ferricrete vão de encontro ao primeiro questionamento apontado acima. Qual a relação entre o solo acima do horizonte ferricrete e este? Para o perfil P1, a presença dos horizontes A (00-10) e E (10-25) de textura areia franca acima do horizonte ferricrete, bem como a transição abrupta entre esses horizontes, sugerem inicialmente sua natureza coluvionar, surgindo assim, posteriormente ao horizonte ferricrete. No entanto, suas presenças são constantes nos perfis P2 e P3 e nos horizontes superficiais de grande parte dos solos da Estação Experimental de Pindorama (Lepsch \& Valadares, 1976) e mais extensivamente, nos solos desenvolvidos sob domínio do arenito Bauru. A filiação genética e evolutiva entre esses horizontes superficiais A e E e o horizonte argílico para solos desenvolvidos do arenito Bauru é defendido e demostrado por Castro (1989), 
Jimenez-Rueda \& Demattê (1988) e Tremocoldi (1982), embora as mobilizações coluvionares possam colaborar para a diferenciação textural entre esses horizontes (Tremocoldi, 1982). Esses argumentos sugerem a possibilidade de uma origem pedogenética, principalmente aos horizontes A e E acima do horizonte ferricrete para o perfil P1. Assim, esses horizontes superficiais podem ter sua origem concomitante ao horizonte ferricrete, ou mesmo ser anterior a ele.

A fim de verificar qual a relação entre os horizontes suprajacentes ao horizonte ferricrete e este, utilizou-se a determinação da distribuição de freqüência do tamanho das partículas como uma ferramenta auxiliar na elucidação dos possíveis mecanismos e processos pedogenéticos envolvidos na gênese desses horizontes e camadas dos perfis estudados. 
Tabela 3. Análise granulométrica (em \%) correspondente a fração menor que $2 \mathrm{~mm}$ e relação $\mathrm{Fe}$ d $/$ argila dos perfis P1, P2 e P3.

\begin{tabular}{|c|c|c|c|c|c|c|c|c|c|c|}
\hline \multirow{2}{*}{ Horizonte $^{1}$} & \multirow{2}{*}{$\begin{array}{l}\text { Profundidade } \\
\qquad(\mathrm{cm})\end{array}$} & \multicolumn{6}{|c|}{ Areia $(\mathrm{mm})^{2}$} & \multirow{2}{*}{$\begin{array}{c}\text { Silte }(\mu) \\
2-50\end{array}$} & \multirow{2}{*}{$\begin{array}{c}\text { Argila }(\mu) \\
<2,0\end{array}$} & \multirow[b]{2}{*}{$\mathrm{F}_{d} /$ argila $^{3}$} \\
\hline & & $\begin{array}{c}\text { AMG } \\
2,0-1,0\end{array}$ & $\begin{array}{c}\mathrm{AG} \\
1,0-0,5\end{array}$ & $\begin{array}{c}\text { AM } \\
0,5-0,25\end{array}$ & $\begin{array}{c}\text { AF } \\
0,25-0,1\end{array}$ & $\begin{array}{c}\text { AMF } \\
0,1-0,05\end{array}$ & $\begin{array}{c}\text { Total } \\
2,0-0,05\end{array}$ & & & \\
\hline \multicolumn{11}{|l|}{ Perfil P1 } \\
\hline A & $00-10$ & 0 & 0 & 13 & 49 & 19 & 81 & 7 & 10 & 0.06 \\
\hline $\mathrm{E}$ & $10-25$ & 0 & 0 & 13 & 49 & 16 & 78 & 14 & 7 & 0,11 \\
\hline Fl-S & $25-45$ & 0 & 1 & 9 & 28 & 15 & 53 & 15 & 29 & 0.15 \\
\hline F1-C & $25-45$ & 0 & 1 & 13 & 38 & 17 & 69 & 24 & 7 & - \\
\hline $\mathrm{F} 2-\mathrm{S}$ & $45-55$ & 0 & 1 & 10 & 26 & 14 & 51 & 14 & 32 & 0,13 \\
\hline $\mathrm{F} 2-\mathrm{C}$ & $45-55$ & 0 & 1 & 7 & 34 & 27 & 69 & 24 & 7 & - \\
\hline $\mathrm{Cr}$ & $55-116$ & 0 & 1 & 15 & 26 & 12 & 54 & 16 & 30 & 0,12 \\
\hline Crgl & $116-140$ & 0 & 0 & 20 & 33 & 10 & 63 & 11 & 25 & 0,09 \\
\hline $\mathrm{Crg} 2$ & $140-180$ & 0 & 0 & 26 & 39 & 10 & 75 & 12 & 12 & 0.11 \\
\hline \multicolumn{11}{|l|}{ Perfil P2 } \\
\hline A & $00-10$ & 0 & 0 & 16 & 49 & 16 & 81 & 10 & 8 & 0,08 \\
\hline $\mathrm{E}$ & $10-26$ & 0 & 0 & 15 & 52 & 13 & 80 & 10 & 10 & 0,09 \\
\hline $\mathrm{Bt1}$ & $26-38$ & 0 & 0 & 12 & 41 & 13 & 66 & 9 & 25 & 0,06 \\
\hline $\mathrm{Bt} 2$ & $38-60$ & 0 & 0 & 16 & 35 & 11 & 62 & 12 & 26 & 0,11 \\
\hline Fl-S & $60-85$ & 0 & 1 & 13 & 31 & 13 & 58 & 11 & 32 & 0,10 \\
\hline $\mathrm{F} 1-\mathrm{C}$ & $60-85$ & 6 & 14 & 16 & 29 & 15 & 80 & 13 & 7 & - \\
\hline $\mathrm{F} 2$ & $85-110$ & 4 & 7 & 13 & 21 & 9 & 54 & 12 & 34 & - \\
\hline $\mathrm{Cr}$ & $110-164$ & 0 & 1 & 10 & 26 & 7 & 44 & 14 & 32 & 0,13 \\
\hline $\mathrm{R}$ & $164-190$ & 0 & 5 & 12 & 19 & 16 & 52 & 30 & 17 & 0.25 \\
\hline \multicolumn{11}{|l|}{ Perfil P3 } \\
\hline A & $00-13$ & 0 & 0 & 19 & 49 & 15 & 83 & 8 & 9 & 0.07 \\
\hline $\mathrm{EA}$ & $13-24$ & 0 & 0 & 21 & 50 & 12 & 83 & 9 & 8 & 0,07 \\
\hline$E$ & $24-67$ & 0 & 1 & 30 & 47 & 6 & 84 & 5 & 12 & 0,06 \\
\hline Btg1 & $67-100$ & 0 & 0 & 20 & 36 & 6 & 62 & 10 & 28 & 0,08 \\
\hline Btg2 & $100-150$ & 0 & 1 & 27 & 37 & 5 & 70 & 4 & 27 & 0.07 \\
\hline
\end{tabular}

${ }^{1}$ F1-S e F2-S: matriz interglebular dos horizontes F para os perfis P1 e P2; ${ }^{1} \mathrm{~F} 1-\mathrm{C}$ e F2-C: glébulas dos horizontes F para os perfis P1 e P2;

${ }^{1} \mathrm{~F} 2$ : amostra homogeneizada (glébula+matriz) para o horizonte plíntico do perfil $\mathrm{P} 2 ;{ }^{3} \mathrm{Fd} / \mathrm{argila}$ : ferro ditionito ou ferro livre sobre argila;

${ }^{2}$ AMG: areia muito grossa; AG: grossa; AM: média; AF: fina; AMF: muito fina. 


\subsubsection{Distribuição de freqüência do tamanho das partículas}

As características de distribuição de freqüência do tamanho das partículas têm sido empregadas em vários estudos de evolução pedogenética dos horizontes do solo. Trabalhos como de Tremocoldi (1982), Coelho et al. (1994), Teramoto (1995) e Cooper (1997) utilizaram as características da curva de distribuição granulométrica através de indices e parâmetros estatísticos, a fim de estabelecer comparações entre sedimentos e/ou camadas de solos. Essas comparações permitem inferir a natureza dos microambientes de deposição e possíveis descontinuidades litológicas (Lier \& Vidal Torrado, 1992).

Para esse estudo foram utilizadas as determinações granulométricas de rotina das amostras coletadas em todos os horizontes dos perfis estudados. As cinco frações de areia obtidas com esta metodologia (Tabela 3), foram analisadas estatisticamente utilizando-se o programa 'PHI' de Lier \& Vidal Torrado (1992).

Os resultados dos fracionamentos granulométricos e utilização do programa 'PHI' foram avaliados visualmente mediante gráficos de barra (histogramas) na escala log-aritmética, bem como em gráfico de linha na escala log-normal e estatisticamente, através dos seguintes parâmetros sugeridos por Folk \& Ward (1957): média gráfica (Mz) e desvio-padrão gráfico inclusivo (s), assimetria gráfica inclusiva (Ski) e curtose gráfica (Kg).

Os histogramas representativos das porcentagens das areias em cada uma das classes granulométricas para todos os horizontes dos perfis (Figura 14, 15 e 16) mostram uma predominância de areia fina (AF), com os maiores valores absolutos dessa fração nos horizontes A e E dos perfis P1 e P2, no Bt1 do P2 e no horizonte EA do perfil P3. Também há uma tendência de aumento relativo dos conteúdos de areia média (AM) com profundidade, principalmente para os perfis P1 e P3. Com relação à fração areia muito fina (AMF), seus maiores conteúdos absolutos encontram-se tanto nos horizontes superficiais de todos os perfis (A e E para P1 e A e EA para P3) como na rocha (R) do perfil P2 e matrizes dos horizontes ferricretes (Tabela 3 e histogramas). Nota-se nos histogramas do perfil P3 (Figura 16), a diminuição progressiva dessa fração com a 
profundidade. Esses resultados evidenciam uma distribuição aleatória obtidos para a fração AMF nos perfis e que podem ter sua origem em diferentes mecanismos.

O comportamento do perfil $\mathrm{P} 3$, que mostrou uma redução da $\mathrm{AF}$ com a profundidade, sugere uma natureza coluvionar para esses grãos mais finos, fato plenamente justificável pela posição do perfil na vertente, uma vez que os materiais mais leves são preferencialmente transportados e podem depositar-se nas porções inferiores da paisagem por meio de erosão diferencial. A máxima expressão desse comportamento é verificado para este perfil, embora a ocorrência de quantidades significativas de AMF nos horizontes superficiais para os perfis P1 e P2 também são parcialmente justificadas pela erosão diferencial, mesmo ocorrendo um aumento gradativo dessa fração com a profundidade (Figuras 14 e 15). Esse último comportamento é esclarecido quando analisamos os demais mecanismos envolvidos na distribuição dessa AMF. Sua presença em maiores proporções relativas na rocha (perfil P2), são indicativos da ocorrência de feldspatos nessa fração, como pode ser verificado no trabalho de Lepsch et al. (1978). Esses autores encontraram $18 \%$ desse mineral na fração areia muito fina para os horizontes inferiores dos perfis ferricretes, os quais intemperizam-se para a fração argila com a evolução do perfil. Esse mecanismo vai de encontro às considerações acima apontadas, onde observa-se um aumento significativo no conteúdo de argila para o horizonte $\mathrm{Cr}$ (Tabela 3), fato que, associado a uma redução de sua fração $\mathrm{AMF}$, como verificado no histograma (Figura 15), explicam parcialmente a distribuição aleatória desta fração no perfil P2.

Outro mecanismo responsável pela distribuição da fração AMF refere-se ao comportamento das matrizes interglebulares dos horizontes ferricretes para os perfis $\mathrm{P} 1 \mathrm{e}$ P2 (F1-S e F2-S para o perfil P1 e F-S para o perfil P2). Seu maior conteúdo relativo nessas porções, podem ser interpretados através do fornecimento dessa fração com o desmantelamento das glébulas, como evidenciado pelas análises micromorfológicas. No entanto, nota-se também um elevado conteúdo relativo da $\mathrm{AMF}$ nos horizontes $\mathrm{Cr}$ do perfil P1. A mobilização dessas frações mais finas da matriz interglebular, as quais são depositadas no horizonte $\mathrm{Cr}$, pode ser responsável por este comportamento, uma vez que 
uma extensa trama de canais, provavelmente intercomunicantes, foi verificado nas análises micromorfológicas. A presença de cerosidade forte e abundante nesse horizonte, bem como de uma significativa ocorrência argilocutânica, como observado nas análises micromorfológicas, corroboram essa hipótese, uma vez que a fração MF pode mover-se associada as argilas (Nahon 1986). As análises micromorfológicas também possibilitaram a confirmação de um segundo mecanismo na geração de partículas na fração areia AMF no $\mathrm{Cr}$. A corrosão do quartzo pela água aparentemente é um processo efetivo nesse horizonte, reduzindo o tamanho médio do esqueleto à fração areia muito fina.

Observando-se os histogramas dos perfis P1 e P2 (Figuras 14 e 15), nota-se um comportamento semelhante entre a matriz das glébulas, entre os horizontes acima e horizonte $\mathrm{Cr}$ abaixo, evidenciando uma possível filiação entre todos os horizontes dos perfis, quais sejam os mecanismos envolvidos nas suas gêneses.

Os dados estatísticos das areias para todos os perfis P1, P2 e P3 encontram-se na Tabela 4. Observa-se para o perfil P1 que a média de tamanho de partícula da fração areia $(\mathrm{Mz})$ está entre 2,4 e 2,7 phi, havendo uma tendência de diminuição com a profundidade. Maiores médias de phi positivos indicam um tamanho de grão mais fino em relação as menores médias positivas de phi ou às médias negativas (Glamble, 1966). Assim, há uma tendência de aumento do tamanho médio das partículas com a profundidade. Esse comportamento também é verificado para aos demais perfis, corroborando os diferentes mecanismos envolvidos na geração de partículas mais finas à medida que se aproxima da superficie.

O desvio padrão (s), medida que informa o grau de selecionamento existente no material (Folk \& Ward, 1957), indicou um material moderadamente selecionado para a maioria dos horizontes. Uma tendência na redução nesse desvio (moderadamente bem selecionado) foi observada para os horizontes $E(10-26 \mathrm{~cm})$ do perfil P2 e horizontes $\mathrm{E}$, Btg1 e Btg2 do perfil P3 indicando um processo seletivo um pouco maior nesses horizontes. Associado a isso, nota-se para todos os horizontes E dos perfis (Tabela 4), os menores desvios-padrão e os maiores tamanhos médios dos grãos em relação aos outros horizontes do solum, com a máxima expressão dessa tendência ocorrendo no perfil P3. 
Esses resultados sugerem a participação de material coluvionar na gênese desses horizontes. Ao lado do mecanismo coluvionar, uma dissolução preferencial dessa fração mais fina (AMF) também pode contribuir para esse comportamento, principalmente quando composto de feldspatos, os quais foram detectados nas análises mineralógicas (silte) e micromorfológicas (silte e areia) deste horizonte. 

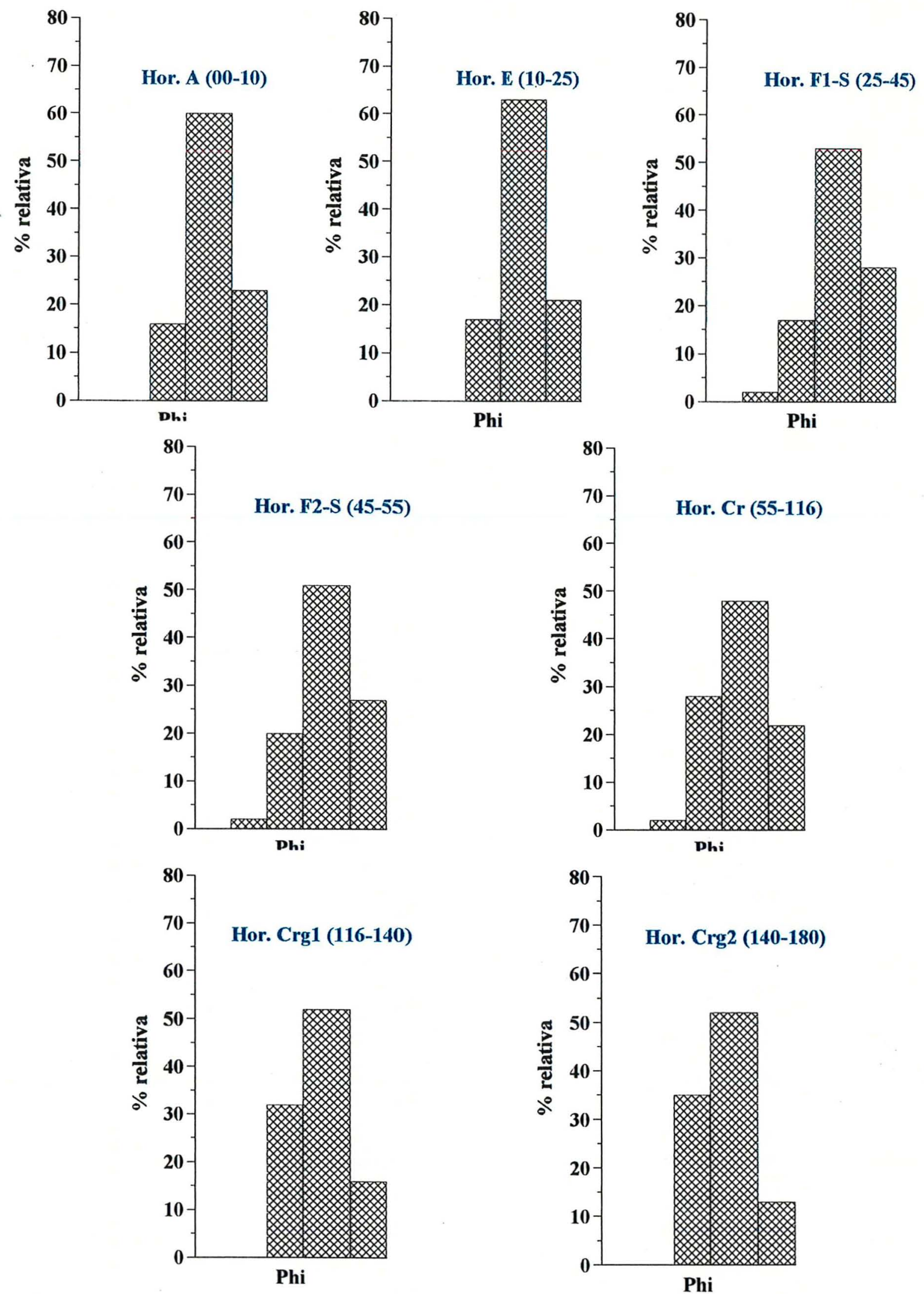

Figura 14. Histogramas representativos das porcentagens das areias em cada uma das classes granulométricas para todos os horizontes do perfil P1. 

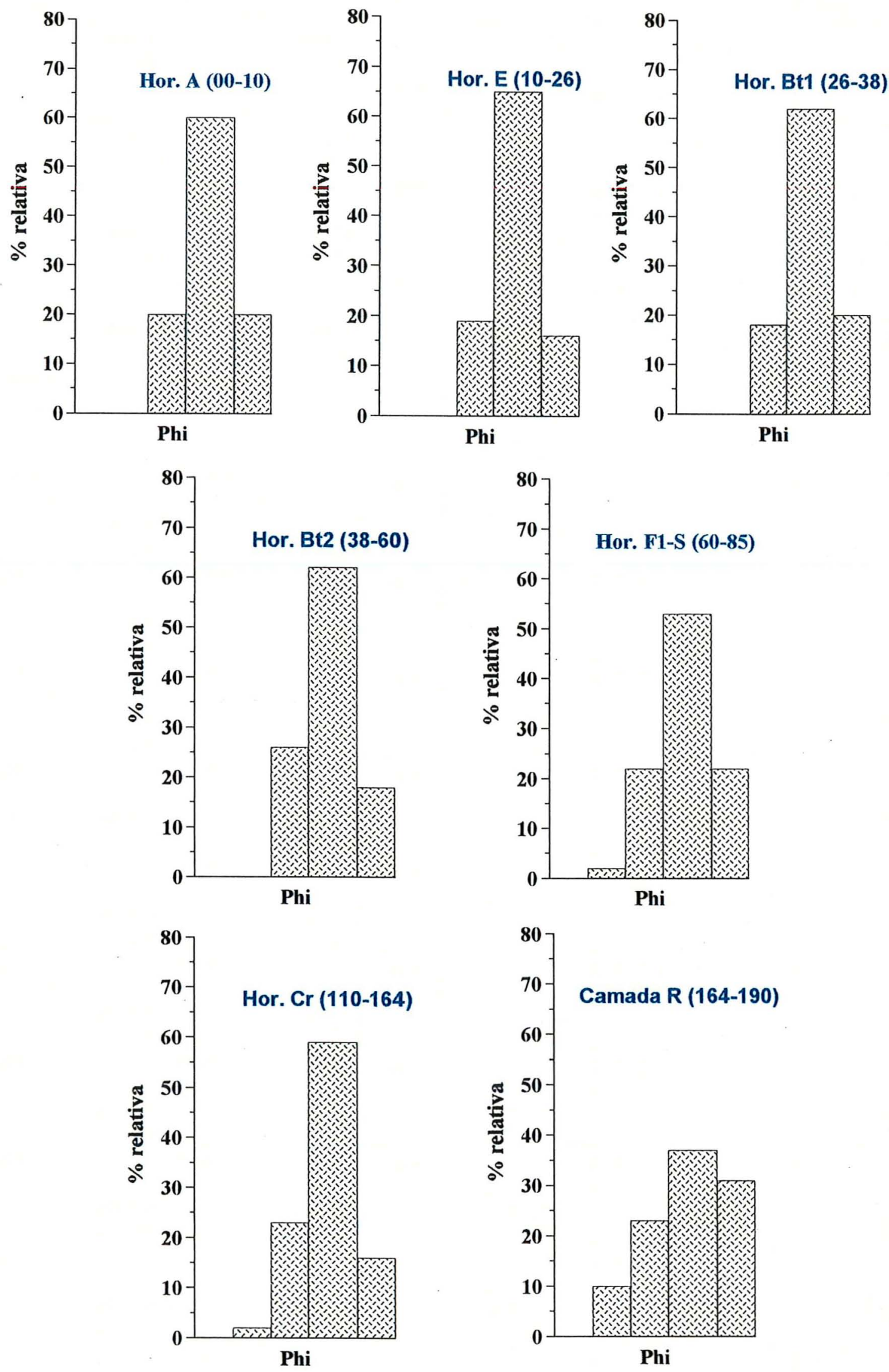

Figura 15. Histogramas representativos das porcentagens das areias para todos os horizontes do perfil P2. 

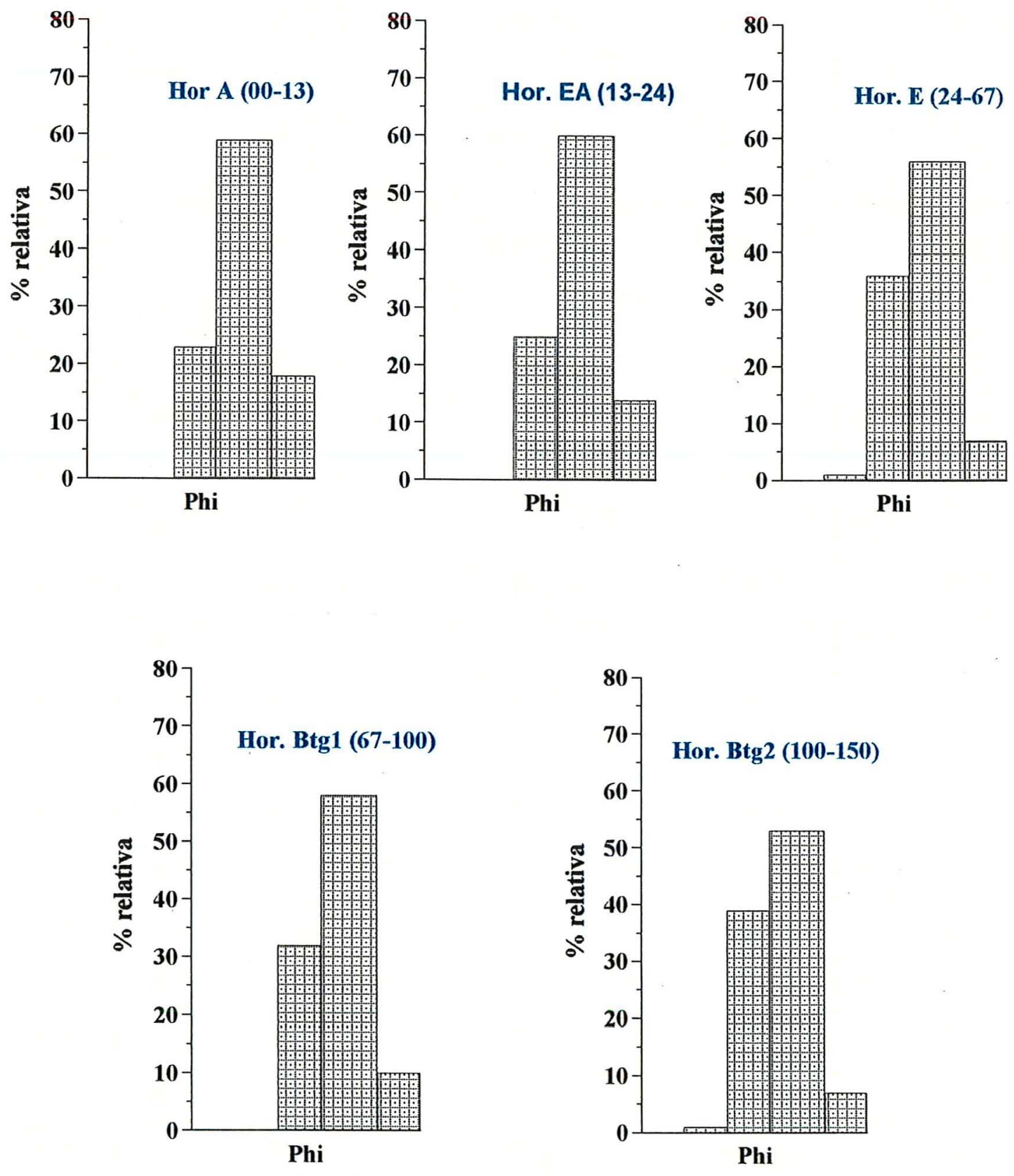

Figura 16. Histogramas representativos das porcentagens das areias para os horizontes do perfil P3. 
A análise do grau de assimetria mostrou uma dominância de uma assimetria gráfica aproximadamente simétrica para todos os horizontes superficiais dos perfis (horizontes A e E). No entanto, uma assimetria positiva, indicando uma "cauda" na curva de distribuição de partículas no sentido de seus menores tamanhos e classificadas como assimétricos finos (Folk \& Ward, 1957) são encontradas nos horizontes inferiores do perfil P1 (Crg1 e Crg2) e nos horizonte E, Btg1 e Btg2 do perfil P3. Essa acumulação não-normal de material mais grosseiro que a média pode ser interpretado como uma herança da rocha de origem, principalmente quando consideramos a fração areia média (M), uma vez que é a fração granulométrica que menor variação (absoluta e relativa) sofreu nos horizontes saprolíticos, tanto para o perfil P1 como para P2, sugerindo uma constituição predominantemente de minerais quartzosos (resistentes ao intemperismo). Esse fato é corroborado com as evidências sugeridas acima, ou seja, os mecanismos envolvidos na distribuição das areias nos perfis com ferricrete, condicionaram os menores diâmetros médios e uma assimetria aproximadamente simétrica, como encontrados nas matrizes dos horizontes glebulares e no solum (P1 e P2). Como no perfil P3 não houve desenvolvimento de materiais ferruginosos endurecidos, os mecanismos sugeridos acima e responsáveis pela distribuição das areias nos horizontes ferricretes não se processaram, e por isso, a fração areia média manteve-se aproximadamente constante desde os horizontes inferiores até os horizontes superficiais, embora haja uma redução relativa à superficie devido a natureza também coluvionar dos horizontes A e EA.

A camada $\mathrm{R}$ do perfil $\mathrm{P} 2$ comportou-se diferentemente dos demais horizontes em termos de assimetria, com uma "cauda" na curva de distribuição de partículas no sentido de seus maiores tamanhos e uma acumulação não-normal de material mais fino que a média, por isso são classificados como assimétricos grosseiros (Folk \& Ward, 1957). Essa distribuição granulométrica corrobora novamente as evidências comentadas acima, ou seja, as frações mais finas nesse horizonte são significativamente ocupadas com feldspatos, como mostrado por Lepsch et al. (1978), uma vez que é na rocha onde esse mineral encontra-se mais preservado e por isso, em maior quantidade. 
A curtose da distribuição das areias, semelhante ao parâmetro assimetria, não mostrou variações nos horizontes superficiais para todos os perfis, predominando o caráter mesocúrtico, porém apresentando uma tendência ao caráter platicúrtico com o aumento da profundidade, principalmente para o horizonte $\mathrm{Bt} 2$ do perfil $\mathrm{P} 2$ e para os horizontes inferiores dos perfis P1 e P2. O perfil P3 manteve-se como mesocúrtico em todos os horizontes, indicando não ter havido uma diferença significativa entre o grau de selecionamento nas extremidades e na parte central da curva. Certamente, isso vem corroborar a influência dos mecanismos apontados acima que interferem na distribuição granulométrica dos perfis ferricretes e que não se processaram no perfil P3, bem como a maior influência de materiais coluvionares por todo P3.

Comparando-se o gráfico de linha na escala log-normal (Figura 17) para os horizontes superficiais (A, E para os perfis P1 e P2 e A e EA para P3) de todos os perfis entre 0 e $25 \mathrm{~cm}$ aproximadamente, bem como seus parâmetros estatísticos desvio padrão, assimetria e curtose (Tabela 4), observa-se uma semelhança entre os horizontes. Todos eles apresentam-se com desvio-padrão enquadrados como moderadamente selecionados (moderadamente bem selecionado para horizonte $\mathrm{E}$ do perfil P2), com assimetria aproximadamente simétrica e curtose com caráter mesocúrtico, embora os tamanhos médios dos grãos aumentem vertente abaixo. Logo, assemelham-se na sua natureza genética. Certamente uma contribuição coluvionar é sempre observada nos horizontes superficiais, como evidenciado acima. No entanto, os comportamentos semelhantes das características de distribuição de freqüência do tamanho das partículas entre os horizontes superficiais, matriz dos horizontes glebulares e horizonte $\mathrm{Cr}$ para os perfis P1 e P2 (histogramas), bem como os diferentes mecanismos envolvidos nas diferenciações granulométricas entre horizontes, como analisados acima, sugerem uma filiação genética entre todos os horizontes dos perfis estudados, inclusive para os horizontes superficiais (A e E) do perfil P1, como defendido e demonstrado por Castro (1989), Jimenez-Rueda \& Demattê (1988) e Tremocoldi (1982) para solos podzólicos abruptos. Portanto, para o perfil P1 é sugerido os mesmos mecanismos pedogenéticos atuantes nos demais perfis e responsáveis pelas atuais conformações dos horizontes. 
Assim, em resposta ao primeiro questionamento apontado neste trabalho, podemos considerar uma evolução pedogenética in situ e portanto, concomitante de todos os horizontes da seqüência estudada, embora a participação coluvionar seja consistente, principalmente para todo o perfil P3. No entanto, evidências químicas, mineralógicas e micromorfológicas serão posteriormente integradas com o objetivo de confirmar e complementar esses resultados, bem como elucidar os demais questionamentos apontados neste trabalho.

$\%$

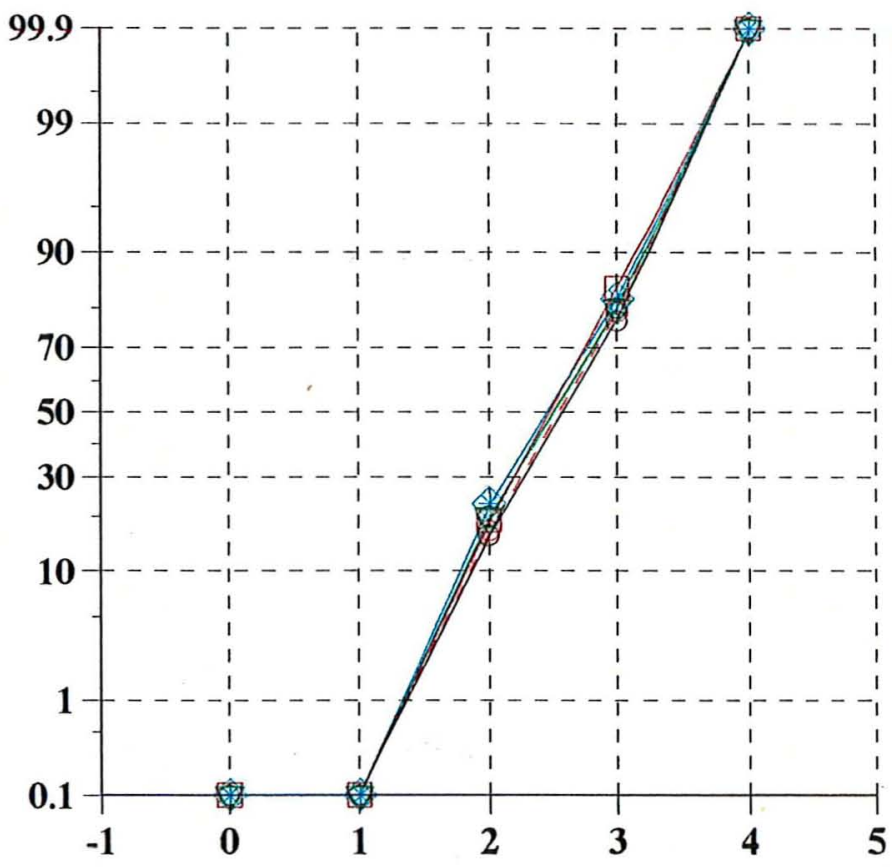

Hor. A perfil P1 $\bigcirc$ Hor. E perfil P1 - $\Theta-$

Hor. A perfil P2 $\rightarrow$

Hor. E perfil P2 $-\square-$

Hor. A perfil P3 $\quad$ *

Hor. EA perfil P3 $\diamond$

Figura 17. Gráfico de linhas log-normal comparando a \% acumulada da distribuição granulométrica das areias para os horizontes superficiais dos três perfis estudados (25 cm superficiais). 
Tabela 4. Cálculos estatísticos da distribuição granulométrica da fração areia, segundo Folk \& Ward (1957).

\begin{tabular}{|c|c|c|c|c|c|c|c|}
\hline $\begin{array}{c}\text { Dados } \\
\text { Estatísticos }\end{array}$ & \multicolumn{7}{|c|}{ Horizontes } \\
\hline Perfil P1 & A & $\mathrm{E}$ & F1-S & F2-S & $\mathrm{Cr}$ & Crg1 & Crg2 \\
\hline Média gráfica (Mz) & 2,736 & 2,699 & 2,739 & 2,691 & 2,554 & 2,477 & 2,401 \\
\hline Desvio padrão (s) & 0,723 & 0,720 & 0.797 & 0,816 & 0,831 & 0,763 & 0,736 \\
\hline assimetria (Ski) & $-0,034$ & $-0,018$ & $-0,098$ & $-0,074$ & $+0,039$ & $+0,125$ & $+0,159$ \\
\hline curtose $(\mathrm{Kg})$ & $+0,956$ & $+0,970$ & $+0,897$ & $+0,851$ & $+0,818$ & $+0,882$ & $+0,921$ \\
\hline Perfil P2 & A & $\mathrm{E}$ & Btl & $\mathrm{Bt} 2$ & F1-S & $\mathrm{Cr}$ & $\mathrm{R}$ \\
\hline Média gráfica (Mz) & 2,650 & 2,610 & 2,675 & 2,561 & 2,617 & 2,531 & 2,508 \\
\hline Desvio padrão (s) & 0,738 & 0,696 & 0,722 & 0,757 & 0,802 & 0,761 & 1,054 \\
\hline assimetria (Ski) & $-0,000$ & $+0,009$ & $-0,009$ & $+0,055$ & $-0,019$ & $+0,013$ & $-0,167$ \\
\hline curtose $(\mathrm{Kg})$ & $+0,937$ & $+1,015$ & $+0,968$ & $+0,885$ & $+0,884$ & $+0,973$ & $+0,801$ \\
\hline Perfil P3 & $\bar{A}$ & & $\overline{E A}$ & $\overline{\mathrm{E}}$ & & & Btg2 \\
\hline Média gráfica (Mz) & 2,592 & & 2,514 & 2,287 & & & 2,257 \\
\hline Desvio padrão (s) & 0,741 & & 0,712 & 0,648 & & & 0,653 \\
\hline assimetria (Ski) & $+0,029$ & & $+0,051$ & $+0,140$ & & & $+0,180$ \\
\hline curtose $(\mathrm{Kg})$ & $+0,924$ & & $+0,960$ & $+0,988$ & & 974 & +0.988 \\
\hline
\end{tabular}




\subsection{Evidências Químicas}

\subsubsection{Análises de rotina}

As propriedades químicas determinadas incluíram: matéria orgânica, reação do solo $(\mathrm{pH})$, bases trocáveis $(\mathrm{SB})$, valor $\mathrm{V}$, capacidade de troca cationica à $\mathrm{pH} 7$ (CTC7) e saturação em $\mathrm{Al}(\mathrm{m})$.

Os dados obtidos para os perfis P1, P2 e P3 encontram-se na Tabela 5. As Figuras 18 e 19 mostram a variação desses atributos com a profundidade, considerando apenas a matriz das glébulas para o horizonte ferricrete. Nota-se pela Figura 18 que os maiores conteúdos de matéria orgânica para os perfis P2 e P3 encontram-se nos horizontes superficiais, com seu maior valor para o horizonte A do perfil P3 $(26,4 \mathrm{~g} / \mathrm{Kg})$.

As glébulas dos horizontes petroplintico mostraram os menores valores de matéria orgânica (1,2 g/kg no F1-C do perfil P1), evidenciando sua origem dissociada deste componente. No entanto, uma concentração superior $(14,4 \mathrm{~g} / \mathrm{kg})$ ao seu horizonte superficial do perfil P1 é observado para F2-C, caracterizados anteriormente como material plíntico. A mobilização da matéria orgânica pode ter-se ocorrido tanto posterior a gênese dessas glébulas, penetrando nos seus poros e fendas, como anteriores, fazendo com que encerrem e fossilizem no seu interior esse constituinte. $O$ fato é que sua mobilização está dissociada do elemento ferro, uma vez que os menores teores de ferro pirofosfato determinado entre as glébulas, foram detectados na amostra plintica F2-C. O baixo conteúdo de matéria orgânica é um requisito necessário ao enquadramento desse material na fase esquelética na FAO (1994) e como material de origem plíntico (Daniels et al., 1978).

Quanto a reação do solo (Figura 18 e Tabela 5), esta manteve-se ligeiramente ácida em todos os horizontes dos perfis estudados. Seu maior valor é registrado para o horizonte A do perfil P1 ( $\mathrm{pH}$ em água $=6,0)$, certamente devido a calagem, prática comum em cultivos de café. Seus menores valores são observados nos horizontes e camada inferiores, com sua máxima expressão na camada $\mathrm{R}$ do perfil $\mathrm{P} 2$. Nesta, os baixos $\mathrm{pH}$ em $\mathrm{KCl}(3,5)$ e $\mathrm{CaCl}_{2}(3,7)$ registrados são função do elevado conteúdo de alumínio 
trocável $(115,2 \mathrm{mmol} / \mathrm{Kg})$, como confirmado nas determinações do elemento e acidez potencial $(\mathrm{H}+\mathrm{Al})$.

Associado as variações de $\mathrm{pH}$, os menores conteúdos de cátions trocáveis (SB) e saturação por bases (V) foram verificados nos horizontes Crg1 e Crg2 do perfil P1, bem como no horizonte $\mathrm{Cr}$ e camada $\mathrm{R}$ no perfil $\mathrm{P} 2$, os quais apresentam grande parte de sua CTC ocupadas com alumínio trocável. Basicamente, podemos atribuir essa elevação da saturação por alumínio em profundidade a dois mecanismos. $\mathrm{O}$ primeiro mecanismo está relacionado à formação e degradação do ferricrete, mobilização do alumínio e deposição nos horizontes e camadas inferiores dos perfis. Este será discutido na apresentação e interpretação dos resultados sobre as dissoluções seletivas. $O$ segundo e mais significativo mecanismo, denominado ferrólise (Brinkman, 1970), está associado a solos ácidos sujeitos a redução sazonal. Nessas condições, o ferro ferroso $\left(\mathrm{Fe}^{2+}\right)$ substitui parte dos cátions e alumínio trocáveis durante o estágio de saturação d'água, deslocando-os dos sítios de troca. $\mathrm{O} \mathrm{H}^{+}$é concentrado durante a oxidação dos compostos ferrosos, podendo induzir a dissolução de parte das estruturas das argilas.

Existem condições adequadas e fortes evidências de desenvolvimento da ferrólise nos perfis estudados. Primeiro, as condições de sazonalidade são satisfeitas para todos os perfis, porém em menor extensão para $\mathrm{P} 2$. Os perfis P1 e P2 permanecem boa parte do período chuvoso com seus horizontes inferiores saturados e o perfil P3, está localizado próximo ao córrego e mostra uma acentuada oscilação no nível de água, como evidenciado nos trabalhos de campo. Também apresentam um conteúdo substancial de ferro, possivelmente boa parte dele devido à sua mobilização do horizonte $F$ e depositado nos horizontes inferiores (perfis P1 e P2), satisfazendo a exigência e necessidade da presença do elemento para o desenvolvimento da ferrólise. Segundo, os mais baixos valores de $\mathrm{SB}$ e os maiores conteúdos de alumínio, acidez potencial e $\mathrm{m}$ são registrados para os horizontes inferiores dos perfis estudados, com a máxima expressão desses índices verificado na rocha $(\mathrm{R})$ do perfil $\mathrm{P} 2$. Nela, também observa-se uma redução no conteúdo de argila, as maiores acumulações de silício total e alumínio extraído com oxalato. Assim, a ferrólise é evidenciada como um mecanismo atuante em todos os perfis 
estudados, liberando $\mathrm{Al}$ da estrutura dos minerais silicatados, os quais estão livres para ocupar os sítios de troca das argilas ou serem incorporados nas estruturas dos óxidos e hidróxidos de ferro secundários. É mais pronunciada nos horizontes inferiores do perfil P2 pelo elevado conteúdo de ferro em relação aos demais horizontes onde a ferrólise é ativa, bem como devido às condições desfavorecem a formação de gibbsita secundária, principalmente pelo elevado conteúdo de sílica presente (Anjos et al., 1995 e Schellmann, 1994). Sua máxima expressão é notada no horizonte $\mathrm{Cr}$ (P2) devido aos menores conteúdos de SB. No entanto, o elevado conteúdo de argila deste horizonte (32\%) em relação a rocha $(17 \%)$, bem com a presença de canais fissurais nesta última (macroporos), como evidenciado nas lâminas delgadas, conferem maiores potenciais de oxidação à essa porção do perfil $(\mathrm{R})$, possibilitando a mobilização do $\mathrm{Al}$ dos horizonte superiores e sua retenção na rocha.

Observando-se o perfil P1, seu maior valor de SB e CTC está na matriz dos horizontes glebulares. Provavelmente o desmantelamento das glébulas é responsável pelo constante rejuvenescimento de sua matriz, como sugerido por Debaveye et al. (1987), uma vez que minerais primários, tais como micas e feldspatos, são constituintes das glébulas. Em relação a seus horizontes superficiais, a maior $\mathrm{SB}$ e V para o horizonte $\mathrm{A}$ $\left(35,2 \mathrm{~mm}_{\mathrm{c}} / \mathrm{Kg}\right.$ e $46 \%$ respectivamente) pode ser atribuída à reciclagem, no entanto observa-se uma diminuição desses índices no horizonte $E$, fato que juntamente com a elevação da saturação em alumínio (passa de $6 \%$ no horizonte A para $28 \%$ no E), sugerem uma lixiviação de cátions básicos.

$\mathrm{O}$ perfil P2 é o que apresenta os maiores valores de SB, CTC e m, como evidenciado nas Figuras 18 e 19. Os elevados valores de CTC e m já foram comentados anteriormente, como correlacionados à ferrólise. No entanto, observa-se uma elevação da SB e CTC com a profundidade, desconsiderando-se o horizonte superficial, sujeito a reciclagem de nutrientes e o horizonte $\mathrm{Cr}$ e camada $\mathrm{R}$, influenciados pela ferrólise, bem como as glébulas. Esse comportamento pode ser interpretado, além da destruição das glébulas no rejuvenescimento da matriz, similarmente ao sugerido para o perfil $\mathrm{P} 1$, como uma mobilização de cátions básicos dos horizontes superiores $\mathrm{A}, \mathrm{E}, \mathrm{Bt} 1 \mathrm{e} \mathrm{Bt} 2 \mathrm{e}$ 
depositados na matriz interglebular. A própria presença de horizontes franco arenosos a superficie com uma evolução pedogenética in situ corroboram essa assertiva. Alguma mobilização lateral desses elementos provindos da paisagem à montante também é esperado para todos os perfis estudados, uma vez que localizam-se no sopé da vertente. Assim, essa mobilização vertical atualmente não é procedente no perfil P1, devido a ausência de horizontes diagnósticos subsuperficiais acima do ferricrete, bem como para o perfil P3, onde não há uma constante "alimentação" de seus horizontes pela degradação das glébulas, fatos que, evidenciam para o perfil P2, a importância da mobilização dos cátions dos horizontes superiores e deposição abaixo, uma vez que a mineralogia da fração argila é basicamente caulinítica e micácea para todos os horizontes dos perfis estudados, como evidenciado nas análise mineralógicas, bem como o conteúdo de argila é pouco variável entre a matriz das glébulas e horizontes texturais.

Em relação às glébulas dos horizontes ferricretes, estas mostram baixos valores de SB e CTC7 (Tabela 5), com seus menores conteúdos para as glébulas F1-C do perfil P2. Esses resultados aproximam dos encontrados por Eswaran \& Mohan (1973) para petroplintita do sul da Índia. Certamente a mineralogia predominantemente oxídica, a elevada cristalinidade dos óxidos e hidróxidos de ferro e o intenso processo de transformações predominantemente desgastantes que se processam durante a gênese dos ferricretes, caracterizados por dissoluções, perdas e transformações de minerais, como relatado por Ambrosi \& Nahon (1986), Muller \& Bocquier (1986) e Nahon (1991), são responsáveis por esses resultados.

A segregação e precipitação do ferro na forma de nódulos, assim como as atuais mobilizações desse elemento, condições hidrológicas dos perfis, diferentes conteúdos de matéria orgânica e presença de horizontes texturais acima do $\mathrm{P} 2$, condicionam as diferenças encontradas entre horizontes e perfis estudados. 
Tabela 5. Análises pedológicas de rotina para os perfis P1, P2 e P3.

\begin{tabular}{|c|c|c|c|c|c|c|c|c|c|c|c|c|c|c|c|}
\hline Hor. & Prof. & $\underset{\mathrm{H}}{\mathrm{pH}}$ & $\underset{\mathrm{KCl}}{\mathbf{p H}}$ & $\underset{\mathrm{CaC}}{\mathbf{p H}}$ & Mo & $\mathbf{p}$ & $\mathbf{K}$ & Ca & $\mathbf{M g}$ & Al & $\mathbf{H}+\mathbf{A l}$ & $\mathbf{S B}$ & CTC7 & \multirow{2}{*}{\multicolumn{2}{|c|}{\begin{tabular}{ll}
$\mathbf{v}$ & $\mathbf{m}$ \\
\hdashline
\end{tabular}}} \\
\hline \multirow{2}{*}{\multicolumn{16}{|c|}{ Perfil P1 }} \\
\hline & & & & & & & & & & & & & & & \\
\hline $\mathrm{A}$ & $00-10$ & 6,0 & 4,8 & 5,3 & 10,0 & 6,2 & 1.2 & 12,1 & 2,8 & 0,9 & 19,1 & 16,2 & 35,2 & 46 & 6 \\
\hline$E$ & $10-25$ & 4,5 & 4,0 & 4,1 & 9,2 & 3,9 & 1,7 & 8,0 & 2,8 & 4,9 & 22,8 & 12,7 & 35,7 & 36 & 28 \\
\hline $\mathrm{Fl}-\mathrm{S}^{1}$ & $25-45$ & 5,3 & 4,3 & 4,6 & 18,3 & 2,1 & 2.8 & 16,3 & 8,1 & 3,2 & 29,1 & 26,8 & 55,8 & 48 & 10 \\
\hline $\mathrm{F} 1-\mathrm{C}^{2}$ & $25-45$ & 5,5 & 4,9 & 5,1 & 1,2 & 0,4 & 2.2 & 9,2 & 4,6 & 0,0 & 20,3 & 16,2 & 36,2 & 45 & 0 \\
\hline $\mathrm{F} 2-\mathrm{S}^{1}$ & $45-55$ & 4,9 & 4,1 & 4,3 & 15,4 & 3,4 & 2,9 & 15,4 & 7,7 & 4,4 & 31,8 & 25,9 & 57,9 & 45 & 13 \\
\hline $\mathrm{F} 2-\mathrm{C}^{2}$ & $45-55$ & 5,1 & 4,7 & 4,9 & 14.4 & 0,5 & 2,0 & 9,7 & 4,7 & 0,0 & 20,3 & 17,0 & 37,0 & 46 & 0 \\
\hline $\mathrm{Cr}$ & $55-116$ & 5,3 & 4,1 & 4,4 & 8,3 & 0,5 & 1.4 & 10,9 & 6,2 & 12,1 & 21,1 & 18,4 & 39,4 & 47 & 40 \\
\hline $\mathrm{Crg} 1$ & $116-140$ & 4,7 & 3,8 & 4,0 & 4,2 & 0,6 & 1.7 & 6.7 & 4,3 & 26,4 & 26,8 & 12,7 & 39,7 & 32 & 67 \\
\hline $\mathrm{Crg} 2$ & $140-180$ & 4,8 & 3,6 & 3.8 & 0,51 & 0.7 & 2.3 & 9,3 & 6,1 & 38,2 & 40,0 & 17,3 & 57,3 & 30 & 69 \\
\hline \multicolumn{16}{|c|}{ Perfil P2 } \\
\hline $\mathrm{A}$ & $00-10$ & 5,1 & 4,2 & 4,6 & 17,4 & 3,8 & 1,9 & 10,9 & 4,9 & 3,1 & 24,1 & 17,9 & 41,9 & 43 & 14 \\
\hline $\mathrm{E}$ & $10-26$ & 5,1 & 4,1 & 4,3 & 12,1 & 0,7 & 1,4 & 8,1 & 1,8 & 3,9 & 22,0 & 11,4 & 33,4 & 34 & 26 \\
\hline Bt1 & $26-38$ & 5,2 & 4,2 & 4,5 & 13,0 & 2,4 & 3,9 & 17,8 & 4,2 & 7,1 & 25,2 & 25,9 & 50,9 & 51 & 21 \\
\hline $\mathrm{Bt} 2$ & $38-60$ & 5,3 & 4,3 & 4,6 & 8,4 & 2,3 & 1,7 & 21,6 & 4,8 & 1,2 & 25,4 & 28,7 & 53,7 & 53 & 3 \\
\hline $\mathrm{F} 1-\mathrm{S}^{l}$ & $60-85$ & 5,5 & 4,6 & 4,9 & 13,2 & 0,8 & 2.3 & 21,7 & 8,2 & 0,0 & 23,2 & 32,3 & 55,3 & 58 & 0 \\
\hline $\mathrm{Fl}-\mathrm{C}^{2}$ & $60-85$ & 5,8 & 5,3 & 5,6 & 3,1 & 0,5 & 1.4 & 6,9 & 2,3 & 0,0 & 4,9 & 10,4 & 15,4 & 68 & 0 \\
\hline $\mathrm{F}^{3}{ }^{3}$ & $85-110$ & 5,4 & 4,2 & 4,4 & 5,0 & 0,6 & 2,6 & 19,1 & 11,1 & 3,1 & 31,4 & 32.6 & 63,6 & 51 & 8 \\
\hline $\mathrm{Cr}$ & $110-164$ & 5,2 & 3,9 & 4.0 & 4,4 & 0,7 & 1.5 & 4,2 & 4,1 & 35,4 & 38,2 & 9,5 & 47,5 & 20 & 79 \\
\hline $\mathrm{R}$ & $164-190$ & 5,1 & 3,5 & 3,7 & 4,3 & 0.7 & 3.6 & 3,1 & 4,1 & 115 & 91,9 & 10,6 & 102,6 & 10 & 92 \\
\hline \multicolumn{16}{|c|}{ Perfil P3 } \\
\hline $\bar{A}$ & $00-13$ & 5,4 & 4,5 & 5,0 & 26,4 & $\overline{6,2}$ & 1.5 & 19,9 & 7,0 & 0,0 & 18,0 & 28.5 & 46,5 & 61 & 0 \\
\hline EA & $13-24$ & 5,3 & 4,2 & 4,7 & 6,2 & 1,9 & 0,9 & 10,1 & 2,8 & 1,1 & 13,1 & 13,9 & 26,9 & 52 & 7 \\
\hline$E$ & $24-67$ & 5,2 & 4,2 & 4,3 & 9,1 & 3,2 & 1,0 & 8.0 & 3,0 & 3,0 & 15,3 & 12,0 & 27,0 & 44 & 20 \\
\hline Btgl & $67-100$ & 5,1 & 4,0 & 4,2 & 15,4 & 2,1 & 0,5 & 15,2 & 6,4 & 9,2 & 38,4 & 21,5 & 59,5 & 36 & 30 \\
\hline Btg2 & $100-150$ & 4,8 & 3,9 & 4,1 & 7,3 & 3.3 & 0,8 & 7,8 & 9 & 10,4 & 26,2 & 17,8 & 43,8 & 41 & 36 \\
\hline
\end{tabular}

${ }^{1} \mathrm{~F} 1$-S e F2-S: matriz interglebular dos horizontes $\mathrm{F} 1$ e $\mathrm{F} 2$ respectivamente;

${ }^{2} \mathrm{~F} 1-\mathrm{C}$ e F2-C: glébulas dos horizontes $\mathrm{F} 1$ e $\mathrm{F} 2$ respectivamente;

${ }^{3}$ F2: horizonte F2 do perfil P2. Amostra homogeneizada (glébulas + matriz). 

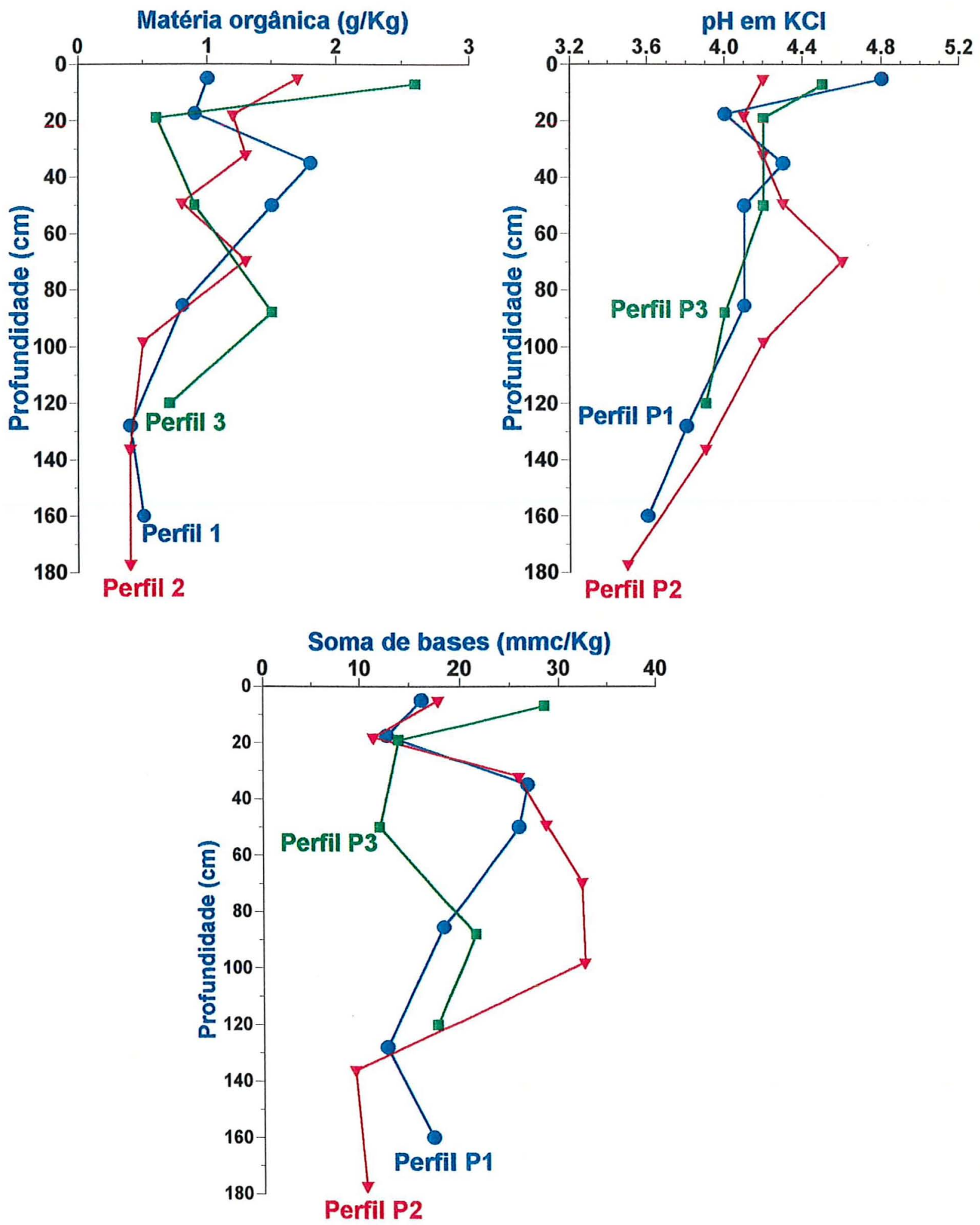

Figura 18. Distribuição da matéria orgânica (MO), $\mathrm{pH}$ em $\mathrm{KCl}(\mathrm{pH} \mathrm{KCl})$ e soma de bases (SB) com a profundidade para todos os perfis estudados (horizonte ferricrete considerou-se apenas sua matriz interglebular). 

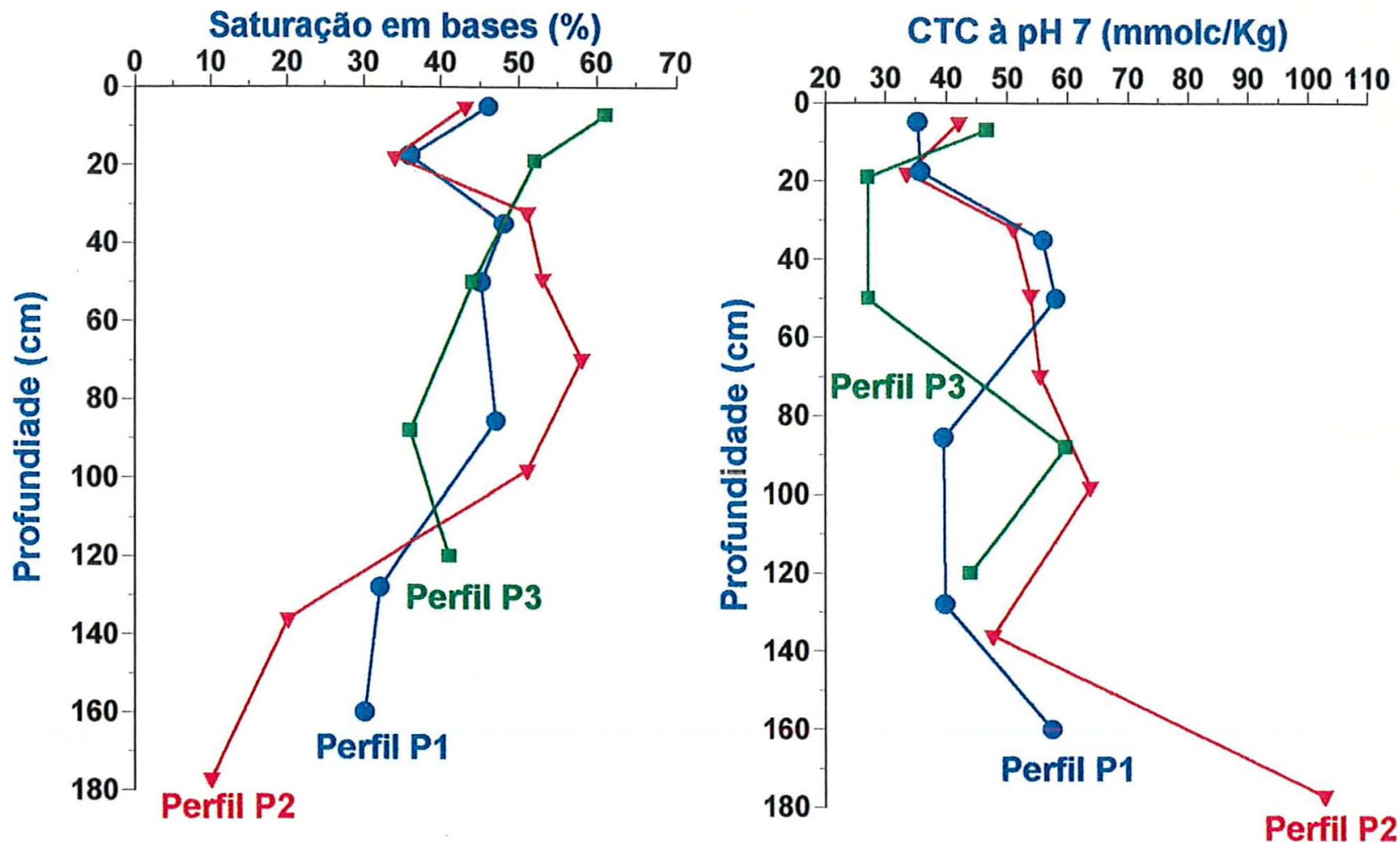

Saturação em alumínio (\%)

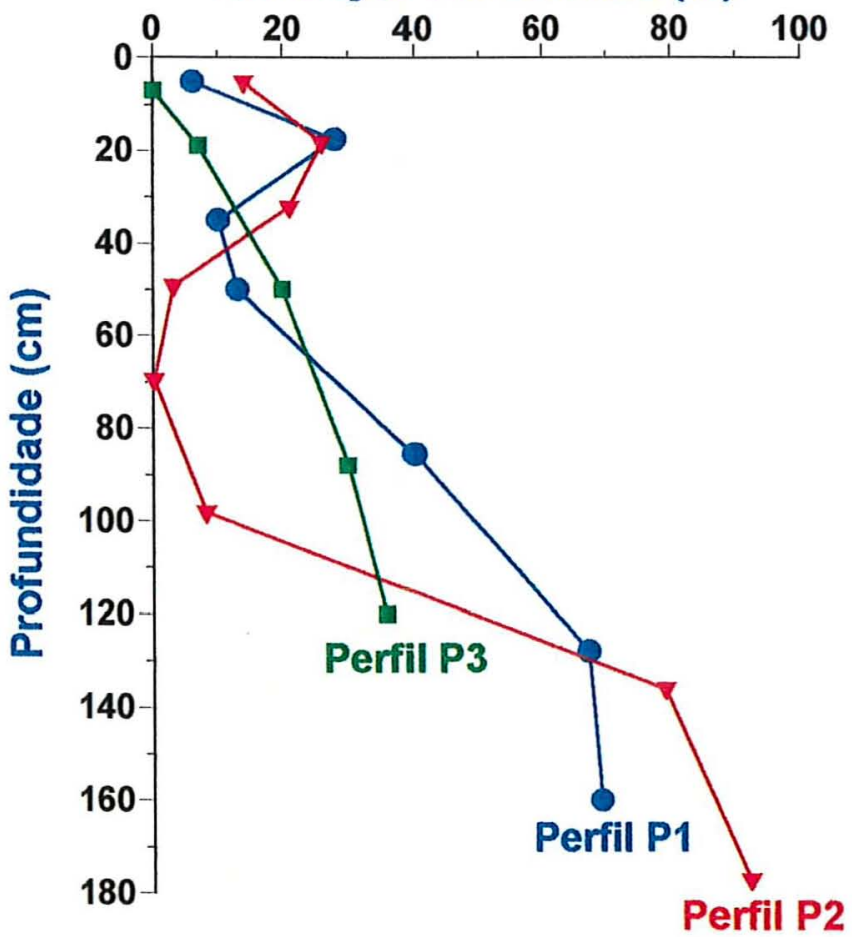

Figura 19. Distribuição da saturação em bases (V), CTC à pH 7 (CTC7) e saturação em alumínio $(\mathrm{m}) \mathrm{com}$ a profundidade para todos os perfis estudados (horizontes ferricretes considerou-se apenas sua matriz). 


\subsubsection{Análises dos elementos totais}

Os conteúdos totais de silício, alumínio, ferro, manganês e titânio extraídos nos solos e glébulas estudados, encontram-se na Tabela 6 . As glébulas mostram os maiores conteúdos de ferro variando entre $156,92 \mathrm{~g} / \mathrm{Kg}$ na plintita do perfil P1 (F2-C), 219,02 $\mathrm{g} / \mathrm{Kg}$ na petroplintita do mesmo perfil e $272,10 \mathrm{~g} / \mathrm{Kg}$ no F1-C do perfil P2. Esses resultados são semelhantes aos encontrados por Ibanga (1980) nas "lateritas" originárias de arenito, embora seus valores variem acentuadamente entre diferentes localidades amostradas ou entre diferentes litologias. No entanto, são inferiores aos apontados por Roquin et al. (1990b) e Tardy \& Roquin (1992) para ferricretes originários de rochas básicas e graníticas. Certamente a litologia interfere no seu conteúdo de ferro (Ibanga, 1980; Roquin et al., 1990b e Tardy \& Roquin, 1992), pois além de influenciar na quantidade e disponibilidade do elemento para a segregação e precipitação "em massa", a pequena superficie específica dos materiais mais arenosos, quando comparado aos argilosos, faz com que menores quantidades do agente cimentante sejam necessários aos primeiros na formação dos ferricretes, como afirmam Alexander \& Cady (1962).

Além da litologia, a idade ou grau de evolução dos ferricretes também interferem no seu conteúdo de ferro. Carapaças ou ferricretes pouco evolúdos são mais pobres no elemento e a natureza da rocha de origem ainda podem ser detectadas (Tardy \& Roquin, 1992). É o caso dos horizontes aqui identificados e descritos como F2 e adjetivados como litodependentes por Roquin et al. (1990b) e Tardy \& Roquin (1992) por refletirem as características morfológicas da rocha abaixo. Os autores acrescentam que o grau de litodependência diminui com a idade ou grau de evolução dos ferricrete a medida que seu conteúdo de ferro aumenta. Assim, podemos considerar que os materiais aqui estudados encontram-se em diferentes estágios evolutivos em resposta ao segundo questionamento apontado neste trabalho. Os horizontes identificados como $\mathrm{F} 1$ ou petroplínticos, mostram uma maior concentração de ferro, maior dureza e não guardam as características morfológicas da rocha mãe, portanto são litoindependentes e mais evoluídos. As plintitas ou carapaças abaixo, apresentam-se morfologicamente semelhantes à rocha mãe, porém com maior impregnação de ferro e também com menor dureza e menores conteúdos do 
elemento em relação às glébulas petroplínticas acima. Essas características conferem a adjetivação de litodopendentes a esses ferricretes imaturos, conforme Roquin et al. (1990b) e Tardy \& Roquin (1992) e confirmam os diferentes estágios evolutivos entre os horizontes plínticos (F2) e petroplínticos (F1).

A relação entre os horizontes petroplinticos e plínticos, ainda em resposta ao segundo questionamento apontado neste trabalho, basicamente pode ser considerada sob dois diferentes aspectos quando enfatizamos a sucessão ou a ordem de formação entre esses materiais (idade). Aquele em que consideramos todos os horizontes estudados como estágios evolutivos na formação dos ferricretes endurecidos à subsuperficie. Neste contexto, os materiais plínticos, à semelhança aos mosqueados abaixo das carapaças, resultam de intermináveis e repetidas transferências e acumulações que se desenvolvem no regolito, gerando uma seqüência de estruturas onde cada uma resulta da evolução da antecedente. Esse mecanismo geoquímico entitulado "auto-organização" por Nahon (1991), também é mostrado em vários trabalhos (Ambrosi \& Nahon, 1986; Muller \& Bocquier, 1986; Nahon, 1986; Tardy \& Nahon, 1985 e Thomas 1994) e podem sugerir que o horizonte petroplíntico resulta da evolução do plíntico numa ordenada e contínua progressão geoquimica. Assim, as plintitas atualmente presentes nos perfis em questão, formaram-se concomitantemente ao desenvolvimento das petroplintitas e esta pela evolução de antigas plintitas. Portanto apresentam a mesma idade, porém diferentes graus de evolução.

Outro aspecto a ser considerado na relação entre esses materiais, envolve a formação atual da plintita pelas transferências e acumulações de matéria que se desenvolvem pela degradação da petroplintita acima. Neste contexto, a plintita atualmente localizada nos perfis, forma-se posteriormente ao material petroplintico e portanto, são mais jovens. Essa última hipótese parece mais adequada a atual morfologia dos perfis e glébulas, e encontram fortes argumentos nas interpretações químicas (dissoluções seletivas).

A existência ou mesmo a ausência de diferentes horizontes ou feições ferruginosas nos perfis ferricretes a fim de especular ou ainda excluir alguns dos principais 
mecanismos concernentes à sua gênese é apontado por McFarlane (1976). Assim, as descrições dos perfis P1 e P2 discutidas anteriormente, evidenciam a ausência de uma progressão ordenada de feições ferruginosas, tais como a presença de mosqueados nos saprolitos abaixo dos horizontes ferricretes, e mesmo uma transição gradual entre os diferentes horizontes ferruginosos, de modo que uma filiação genética possa ser estabelecida e interpretada como uma progressão vertical das diferentes fácies ferruginosas, como demonstrado por Ambrosi et al. (1986), Ambrosi \& Nahon (1986), Nahon (1991) e Tardy \& Nahon (1985).

Em relação às glébulas plínticas, notadamente do perfil P2, essas mostram um córtex ferruginoso endurecido de coloração vermelho-escuro-acinzentado (10R 3/3) mantendo e encerrando as estruturas e formas dos saprolitos abaixo, porém com maiores conteúdos de ferro, sugerindo com essa morfologia uma mobilização do elemento dos horizontes ferricretes acima e sua maior segregação e precipitação nas bordas dos fragmentos saprolíticos, cujos mecanismos serão posteriormente discutidos. Também, a formação das glébulas petroplínticas por um processo de remoção dos constituintes do material plíntico abaixo e seu posterior endurecimento, tal como demonstrado por Gallaher et al. (1974), sugerindo que o horizonte petroplíntico resulta da evolução do plíntico numa ordenada e contínua progressão geoquímica, é pouco provável quando verificamos o perfil P1. Observando-se o conteúdo de silício da plintita em relação à petroplintita (Tabela 6), nota-se teores inferiores para as glébulas plínticas, evidenciando que esses materiais não foram formados concomitantemente, uma vez que condições similares de intemperismo condicionariam conteúdos superiores de silício ao material plíntico, eminente precursor da petroplintita. Como a plintita é mais jovem, diferentes condições de intemperismo são responsáveis pelo seu menor conteúdo de silício em relação à petroplintita acima.

Portanto, as interpretações aqui estabelecidas evidenciam que os horizontes plínticos são os produtos do desmantelamento das couraças, e cujos processos envolvem a mobilização vertical do ferro e sua segregação e precipitação no horizonte saprolítico imediatamente abaixo, tal como demonstrado por vários autores (Alexander \& Cady, 
1962; Ambrosi \& Nahon, 1986; Beauvais et al., 1990; Beauvais \& Tardy, 1991; Beauvais \& Tardy, 1993; Fölster et al., 1971; King et al., 1990; Maignien, 1966; McFarlane, 1976; Sivarajasingham et al., 1962; Tardy, 1992; Tardy \& Nahon, 1985 e Tardy et al., 1988), sendo assim, mais jovens em relação ao material petroplíntico acima. No entanto, os mesmos mecanismos podem estar envolvidos na formação dessas feições, de modo que a atual plintita pode evoluir para petroplintita a partir dos sucessivos aportes de ferro provindos da degradação desta última, bem como, através do estabelecimento de condições hidrológicas adequadas à cristalinização e endurecimento do cimento ferruginoso.

Ainda com relação ao elemento ferro, os menores conteúdos são verificados para os horizontes EA $(5,92 \mathrm{~g} / \mathrm{Kg})$ e E $(7,93 \mathrm{~g} / \mathrm{Kg})$ do perfil P3. Possivelmente, a consistente natureza coluvionar desse perfil, associado a sua maior umidade, a qual condiciona os potenciais de oxidorredução mais adequados à remoção do ferro (Schwertmann \& Taylor, 1989), são responsáveis por esse comportamento.

$\mathrm{O}$ conteúdo de manganês $(\mathrm{Mn})$ é baixo em todos os perfis estudados. Os menores valores são encontrados nas glébulas $(0,16 \mathrm{~g} / \mathrm{Kg})$ e nos horizontes $\mathrm{E}, \mathrm{Bt} 1$ e $\mathrm{Bt} 2(0,16$ $\mathrm{g} / \mathrm{Kg})$ do perfil P3. No entanto, a maior concentração do elemento no horizonte $\mathrm{Cr}(0,78$ $\mathrm{g} / \mathrm{Kg})$ e camada $\mathrm{R}(0,93 \mathrm{~g} / \mathrm{Kg})$ do perfil P2 já foi comentado anteriormente como resultado das condições hidrológicas atuais da seqüência estudada. Os baixos conteúdos no perfil P3, também são condicionados pelas condições hidrológicas atuais deste perfil, uma vez que Mn pode ser largamente perdido dos solos sob condições úmidas (Schwertmann \& Fanning, 1976). Portanto, as glébulas aqui são essencialmente ferruginosas, com baixos teores de manganês, ao contrário dos nódulos e concreções estudados por Schwertmann \& Fanning (1976) e Rhoton et al. (1993), embora algumas poucas mostram-se enegrecidas no seu interior, evidenciando a presença do elemento. Os mecanismos envolvidos na de formação dessas glébulas já foram discutidos nos resultados morfológicos.

Comparando-se os conteúdos de silício (Si) e alumínio (Al) na Tabela 6 observase que os menores valores estão nos horizontes superficiais. Esses resultados certamente 
refletem as menores porcentagens de argila entre todos os horizontes dos perfis estudados. No entanto, o índice de intemperismo Ki são elevados $(>2)$, sugerindo a presença de minerais micáceos e feldspatos nas frações mais finas (argila e silte) dos horizontes franco arenosos superficiais. Os maiores conteúdos de Si são encontrados na rocha $(\mathrm{R})$ do perfil $\mathrm{P} 2$ e também refletem parcialmente os maiores conteúdos de mica $\mathrm{e}$ feldspatos, como evidenciado pelas análises mineralógicas. Em relação ao $\mathrm{Al}$, para o perfil P1 há um aumento do seu conteúdo nos horizontes saprolíticos a medida que se caminha para a superficie. Esses resultados acompanham o aumento dos conteúdos de $\mathrm{Si}$ e argila uma vez que $\mathrm{o}_{2} \mathrm{SO}_{4}$ forte dissolve principalmente essa fração do solo (Anjos, et al., 1995) e portanto, o conteúdo desses elementos corresponde à quantidade de alumínio e silício na fração argila e evidenciam os mecanismos apontados nos resultados morfológicos e granulométricos, ou seja, a argiluviação e/ou intemperização dos minerais primários da rocha no aumento e formação da argila no saprolito.

Em relação às glébulas, são verificados menores conteúdos de $\mathrm{Si}$ e $\mathrm{Al}$ quando comparamos à sua matriz interglebular. Considerando-se uma origem in situ, esses resultados sugerem a atuação dos mecanismos de dissolução da caulinita na formação e desmantelamento das couraças e carapaças, como proposto por Ambrosi et al. (1986), Beauvais \& Tardy (1991), Muller \& Bocquier (1986) e Nahon (1991). Comparando-se apenas as glébulas, observa-se os menores teores desses elementos, assim como o menor valor de Ki para o perfil P2 (F-C). Isso reflete os mais baixos conteúdos de caulinita e corroboram a atuação dos mecanismos de dissolução do mineral a medida que o ferro é acumulado na formação do ferricrete, uma vez que o aumento da concentração desse elemento induz à desestabilização da caulinita por uma progressiva substituição isomórfica do $\mathrm{Fe}$ na estrutura desse mineral silicatado (Muller \& Bocquier, 1986). Assim, as maiores deposições de ferro no perfil P2 levam as maiores substituições isomórficas na estrutura da caulinita, desestruturando e dissolvendo-a em seus constituintes solúveis, ou seja, sílica e alumínio. Algum alumínio liberado torna-se componente da Al-hematita, no entanto, a maior parte desse elemento, juntamente com o $\mathrm{Si}$, migram a curtas distâncias e podem reprecipitar como uma nova geração de caulinita (Nahon, 1991). Também, o 
desmantelamento da couraça é responsável pela desestabilização da associação caulinitahematita e liberação dos seus constituintes ferro, alumínio e silício (Beauvais \& Tardy, 1991), os quais são lixiviados do horizonte ferricrete e podem depositar-se nos horizontes inferiores. Assim, a remobilização desses elementos, tanto pela formação (horizonte F2) como degradação (horizonte F1) das glébulas, podem ser parcialmente responsáveis pelo elevado conteúdo de Si total no horizonte F2 e na rocha do perfil P2, uma vez que o conteúdo de $\mathrm{Al}$ total pouco variou entre esses horizontes inferiores (F2 e $\mathrm{Cr}$ ) e camada $\mathrm{R}$ deste perfil, bem como o elemento Si é preferencialmente remobilizado em relação ao Al. Essa última assertiva é corroborada quando se observa a pequena variação no conteúdo desse último elemento entre as glébulas dos perfis (F1-C e F2-C do perfil P1 e F-C do perfil P2), no entanto, o silício varia consideravelmente.

Comparando-se o elemento titânio ( $\mathrm{Ti}$ ), observa-se que seus maiores conteúdos encontram-se nas glébulas. Esses resultados sugerem a participação dos mecanismos de natureza residual na gênese dos ferricretes, ou seja, o enriquecimento do Fe é devido à remoção dos outros constituintes e acumulação de elementos pouco móveis e resistentes ao intemperismo (McFarlane, 1976). Embora o elemento Ti seja passível de mobilidade em determinados ambientes pedogenéticos (Milnes \& Fitzpatrick, 1989), geralmente sua acumulação relativa é esperada nos processos de laterização devido à sua resistência ao intemperismo. Essa origem residual na gênese dos ferricretes é bem aceita nos dias atuais (Aleva, 1994 e McFarlane, 1983), no entanto, "lateritas nas posições de sopé de vertente usualmente possuem muito de sua concentração proveniente da acumulação absoluta" de ferro (McFarlane, 1983, p.21). Portanto, é proposto aqui algum desenvolvimento in situ para esses ferricretes dos baixos níveis topográficos os quais são considerados predominantemente de acumulações absolutas, pois como afirma McFarlane (1976, p21), essa natureza residual está "freqüentemente associada", de modo que as "lateritas" nessas posições da vertente "são apenas parcialmente detritais".

Evidências da origem de lençol para os ferricretes aqui estudados já foram comentadas anteriormente e podemos argumentar, ainda em resposta ao terceiro questionamento apontado neste trabalho, que a origem do ferro na formação dos 
ferricretes é primordialmente proveniente de fontes externas. Algumas evidências morfológicas e químicas corroboram esse apontamento. Como exemplo, podemos sugerir que a ausência de um perfil de intemperismo típico, tal como descrito McFarlane (1976) e McFarlane (1986), indica que o enriquecimento de ferro não é residual, mas originário principalmente do transporte lateral de ferro. $O$ influxo lateral desse elemento é responsável pelo constante suprimento de $\mathrm{Fe}^{2+}$ às posições inferiores da paisagem (Maignien, 1966), descarregando no lençol freático e precipitando o $\mathrm{Fe}^{3+}$ em sua superficie, dando origem a esses ferricretes dos baixos níveis topográficos, conforme sugerido por vários autores (Bigarella et al., 1996; Bourman, 1993; Bourman et al., 1987 e McFarlane, 1983). Também, como uma zona de lixiviação do ferro (zona pálida) não se encontra abaixo do horizonte ferricrete, uma migração ascendente e o enriquecimento do elemento na forma de ferricrete, como sugerido por Mann \& Ollier (1985), pode ser excluída. Outro argumento que evidencia a origem do ferro predominantemente das fontes externas, refere-se ao comportamento do Al (Schwarz, 1994). Esse elemento não foi enriquecido significativamente na forma de minerais bauxíticos ou goetita aluminosa no ferricrete, como evidenciado nas análises químicas totais, mineralógicas $\mathrm{e}$ submicroscópicas, de modo que uma consistente concentração residual é descartada. Certamente, a existência dos ferricretes apenas nos sopés de vertente é o principal argumento a confirmar sua origem predominantemente de lençol.

Em suma, podemos concluir em resposta ao terceiro questionamento apontado neste trabalho, que os ferricretes na área estudada são predominantemente alóctones, ou seja, oriundos de aportes externos de ferro provindos da paisagem à montante $\mathrm{e}$ depositados no estreito limite de oscilação do lençol freático. No entanto, alguma contribuição residual foi evidenciada, sugerindo um rebaixamento da paisagem e concentração dos elementos pouco móveis na gênese desses materiais ferruginosos endurecidos. 
Tabela 6. Análise dos elementos totais (ataque sulfúrico) e dissoluções seletivas para os perfis P1, P2 e P3.

\begin{tabular}{|c|c|c|c|c|c|c|c|c|c|c|c|c|c|c|c|c|c|}
\hline Hor. ${ }^{\prime}$ & Prof. & $\mathrm{Si}$ & $\overline{\mathrm{Al}_{\mathrm{t}}}$ & $\mathrm{Al}_{\mathrm{d}}$ & $\mathrm{Al}_{\mathrm{o}}$ & $\mathrm{Fe}_{\mathrm{t}}$ & $\mathrm{Fe}_{\mathrm{d}}$ & $\mathrm{Fe}_{\mathrm{o}}$ & $\mathrm{Fe}_{\mathrm{h}}$ & $\mathrm{Fe}_{\mathrm{p}}$ & $\overline{\mathrm{Ti}}$ & $\mathrm{Mn}_{\mathrm{t}}$ & $\mathrm{Mn}_{\mathrm{d}}$ & $\mathrm{Mn}_{\mathrm{o}}$ & $\mathrm{Mn}_{\mathrm{h}}$ & $\mathrm{Fe}_{\mathrm{o}} / \mathrm{Fe}_{\mathrm{d}}$ & $A l_{d} / \mathrm{Fe}_{d}$ \\
\hline & & \multicolumn{11}{|c|}{-1} & \multicolumn{3}{|c|}{$----m g / K g-----$} & $-. \%--$ & \\
\hline \multicolumn{18}{|c|}{ Perfil P1 } \\
\hline $\mathrm{A}$ & $00-10$ & 19,25 & 13,92 & 1,32 & 0,53 & 12,94 & 5,51 & 0,68 & 0,12 & 0,82 & 12,16 & 0,31 & 68,01 & 71,69 & 81,54 & 12,38 & 0,24 \\
\hline $\mathrm{E}$ & $10-25$ & 22,99 & 19,42 & 1,78 & 0,59 & 18,95 & 7,68 & 0,73 & 0,09 & 1,44 & 12,76 & 0,31 & 43,54 & 43,19 & 51,29 & 9,56 & 0,23 \\
\hline Fl-S & $25-45$ & 56,96 & 54,87 & 3,82 & 1,45 & 48,25 & 44,34 & 1,66 & 0,11 & 1,41 & 16,38 & 0,23 & 54,59 & 10,56 & 19,31 & 3,73 & 0,09 \\
\hline $\mathrm{F} 1-\mathrm{C}$ & $25-45$ & 48,90 & 47,35 & 6,83 & 1,26 & 219,02 & 215,92 & 11,41 & 1,19 & 0,27 & 24,48 & 0,16 & 87,90 & 2,12 & 8,47 & 5,28 & 0,03 \\
\hline $\mathrm{F} 2-\mathrm{S}$ & $45-55$ & 65,75 & 56,93 & 5,17 & 1,53 & 44,48 & 40,09 & 1,78 & 0,08 & 1,05 & 16,90 & 0,23 & 39,22 & 5,65 & 10,00 & 4,44 & 0,13 \\
\hline $\mathrm{F} 2-\mathrm{C}$ & $45-55$ & 42,01 & 47,35 & 7,07 & 1,44 & 156,92 & 149,43 & 15,12 & 1,31 & 0,22 & 21,47 & 0,16 & 89,22 & 8,48 & 9,07 & 10.12 & 0,05 \\
\hline $\mathrm{Cr}$ & $55-116$ & 59,02 & 56,30 & 3,62 & 1,63 & 37,20 & 35,39 & 1,48 & 0,05 & 0,11 & 16,03 & 0,23 & 45,19 & 5,45 & 7.26 & 4.19 & 0,10 \\
\hline Crgl & $116-140$ & 48,13 & 45,71 & 3,18 & 1,42 & 31,19 & 23,15 & 1,03 & 0,04 & 0,11 & 13,97 & 0,23 & 42,36 & 3,63 & 4,45 & 4,47 & 0,14 \\
\hline $\mathrm{Crg} 2$ & $140-180$ & 47,20 & 30,69 & 1,24 & 1,17 & 21,61 & 9,88 & 0,80 & 0,03 & 0,12 & 9,31 & 0,16 & 24,71 & 5,45 & 12,10 & 8,08 & 0,13 \\
\hline \multicolumn{18}{|c|}{ Perfil P2 } \\
\hline A & $00-10$ & 15,93 & 13,39 & 0,87 & 0,42 & 20,07 & 6,52 & 0,75 & 0,16 & 0,70 & 9,31 & 0,31 & 121,76 & 99,51 & 141,71 & 11,42 & 0,13 \\
\hline$E$ & $10-26$ & 21,07 & 17,25 & 1,16 & 0,53 & 15,59 & 8,70 & 0,71 & 0,09 & 0,76 & 10,17 & 0,31 & 104,98 & 82,84 & 117,8 & 8,21 & 0,13 \\
\hline $\mathrm{Btl}$ & $26-38$ & 30,09 & 43,28 & 2,71 & 1,08 & 28,04 & 14,60 & 1,15 & 0,09 & 1,15 & 13,36 & 0.23 & 47,12 & 23,65 & 31,53 & 7,91 & 0,19 \\
\hline $\mathrm{Bt} 2$ & $38-60$ & 56,59 & 55,08 & 3,67 & 1,32 & 34,76 & 28,78 & 1,50 & 0,08 & 1,11 & 13,97 & 0,23 & 63,97 & 19,62 & 22,59 & 5,21 & 0,13 \\
\hline$F 1-S$ & $60-85$ & 57,52 & 56,77 & 3,28 & 1,64 & 41,12 & 33,23 & 1,86 & 0,11 & 1,01 & 13,62 & 0,23 & 50,07 & 14,29 & 17,84 & 5,59 & 0,10 \\
\hline F1-C & $60-85$ & 33,04 & 45,71 & 7,90 & 1,07 & 272,10 & 269,62 & 6,94 & 0,83 & 0,36 & 26,21 & 0,16 & 83,97 & 4,24 & 4,90 & 2,58 & 0.03 \\
\hline F2 & $85-110$ & 96,78 & 69,21 & 4,34 & 2,68 & 91,68 & 86,84 & 2,42 & 0,09 & 0,16 & 18,19 & 0,39 & 103.93 & 69,54 & 34,80 & 2,78 & 0,05 \\
\hline $\mathrm{Cr}$ & $110-164$ & 69,11 & 64,18 & 2,89 & 2,62 & 44,20 & 40,72 & 2,00 & 0,11 & 0,11 & 17,33 & 0,78 & 281,76 & 670,24 & 168,30 & 4,92 & 0,07 \\
\hline $\mathrm{R}$ & $164-190$ & 106,92 & 65,93 & 4,41 & 6,06 & 55,80 & 40,80 & 2,17 & 0,48 & 0,07 & 19.22 & 0,93 & 898,05 & 1545,60 & 2116,00 & 5,31 & 0,10 \\
\hline \multicolumn{18}{|c|}{ Perfil P3 } \\
\hline $\mathrm{A}$ & $00-13$ & 21,12 & 13,92 & 0.56 & 0,44 & 14,06 & 6,42 & 0,94 & 0,15 & 1,24 & 9,91 & 0.39 & 150,32 & 155,01 & 226,01 & 14,60 & 0,09 \\
\hline EA & $13-24$ & 22,01 & 12,22 & 0,50 & 0,40 & 5,92 & 5,28 & 0,78 & 0,07 & 0,80 & 6,90 & 0,23 & 114,92 & 114,62 & 131,29 & 14,70 & 0,09 \\
\hline $\mathrm{E}$ & $24-67$ & 27,15 & 17,78 & 0,78 & 0,55 & 7,93 & 7,14 & 1,56 & 0,10 & 1,15 & 6,72 & 0,16 & 83,24 & 89,61 & 86,50 & 21,84 & 0,11 \\
\hline Btgl & $67-100$ & 53,32 & 52,91 & 2,35 & 1,32 & 24,48 & 21,89 & 3,10 & 0,17 & 0.69 & 11,64 & 0,16 & 69,89 & 44,77 & 33,28 & 14,17 & 0,11 \\
\hline Btg2 & $100-150$ & 56,64 & 53,33 & 1,95 & 1,31 & 26,99 & 18,20 & 2,91 & 0,16 & 0,41 & 11,38 & 0,16 & 47,87 & 19,50 & 14,34 & 15,97 & 0,11 \\
\hline
\end{tabular}

${ }^{1} \mathrm{~F} 1-\mathrm{S}$ e F2-S: matriz interglebular dos horizontes F1 e F2 respectivamente; F1-C e F2-C: glébulas do horizontes F1 e F2 respectivamente; F2:

horizonte F2 (amostra homogeneizada - glébulas + matriz);

Subscritos: t: total; d: ditionito; o: oxalato; h: hidroxilamina; p: pirofosfato; 


\subsubsection{Análises das dissoluções seletivas}

As técnicas de dissoluções seletivas tem sido usadas com sucesso para a resolução de um número de problemas dentro da química do solo, e de modo especial no entendimento da formação dos óxidos de ferro e gênese dos solos (Blume \& Schwertmann, 1969; Ibanga et al., 1983; McKeague \& Day, 1966 e Schwertmann, 1973). Também aqui, as determinações de ferro, alumínio e manganês obtidos por diferentes extratores seletivos (Tabela 6), além de caracterizar os perfis ferricretes, objetivam elucidar e corroborar os diferentes mecanismos envolvidos na gênese desta porção da paisagem sob domínio das feições ferruginosas. No entanto, alguns esclarecimentos sob as diferentes metodologias utilizadas são úteis para uma melhor interpretação dos resultados.

O conteúdo de ferro total $\left(\mathrm{Fe}_{\mathrm{t}}\right)$ determinado após dissolução da amostra com $\mathrm{H}_{2} \mathrm{SO}_{4}$ concentrado inclui todas as possíveis fontes de $\mathrm{Fe}$ na fração argila (Anjos, et al., 1995). Técnicas de dissolução seletiva tem sido usada por muitos anos para se obter uma partição dos compostos de ferro em várias fases (Costa, 1996). Com essa finalidade, Holmgren (1967) desenvolveu o método do ditionito-citrato (DC) por exemplo, visando uma metodologia eficiente, rápida e adaptável às análises de rotina na remoção de todos os óxidos de ferro livres nas amostras pelo uso de um agente redutor forte (ditionito de sódio) e um agente complexante e tamponante (citrato). No entanto, o método não distingue entre as várias espécies de óxidos de ferro, tais como óxidos e oxihidróxidos de ferro bem cristalinizados, formas amorfas e as unidas a matéria orgânica (McKeague \& Day, 1966), e portanto, esse elemento removido com o extrato $\left(\mathrm{Fe}_{\mathrm{d}}\right)$ é uma média da composição química de todas as fases dissolvidas (Costa, 1996). Esse método geralmente extrai conteúdos similares de Fe em relação ao bem conhecido DCB (ditionito-citratobicabornato) (Partiff \& Childs, 1988). Por outro lado, o procedimento oxalato-oxálico (Schwertmann, 1973), agente complexante e redutor suave (Barral Silva, 1987), remove somente as fases inorgânicas pouco cristalinas (ferridrita por exemplo; $\mathrm{Fe}_{\mathrm{o}}$ ), bem como o aluminio associado com húmus $\left(\mathrm{Al}_{\mathrm{o}}\right)$ (Partiff \& Childs, 1988). A relação entre o ferro extraído pelos dois métodos $\left(\mathrm{Fe}_{\mathrm{o}} / \mathrm{Fe}_{\mathrm{d}}\right)$ é chamada de ferro ativo (Blume \& Schwertann, 
1969) e tem sido amplamente usada na avaliação dos processos pedogenéticos, no grau de desenvolvimento dos perfis e cristalinidade dos óxidos de ferro (Anjos et al., 1995; Barral Silva, 1987; Blume \& Schwertmann, 1969; Costa, 1996; Gamble \& Daniels, 1972; McKeague \& Day, 1966; Moore, 1973; Rhoton, et al., 1981; Rhoton et al., 1993; Schwertmann \& Kämpf, 1983 e Schwertmann \& Taylor, 1989).

Outros extratores, tais como pirofosfato e hidroxilamina, foram também utilizados tanto nas determinações do ferro associado a matéria orgânica $\left(\mathrm{Fe}_{\mathrm{p}}\right)$, como nas formas facilmente redutiveis de ferro $\left(\mathrm{Fe}_{\mathrm{h}}\right)$ e manganês $\left(\mathrm{Mn}_{\mathrm{h}}\right)$ respectivamente, complementando assim, as técnicas dissoluções seletivas. No entanto, trabalhos recentes tem evidenciado uma pequena especificidade do reagente pirofosfato para determinados tipos de solos. Particularmente, os solos contendo goetita ou ferridrita, associados a elevados conteúdos de caulinita ou vermiculita, o reagente pirofosfato pode causar a dispersão dos óxidos e, por conseguinte, elevados valores de $\mathrm{Fe}_{\mathrm{p}}$ são obtidos (Partiff \& Childs, 1988). As formas facilmente redutiveis de ferro e manganês, cujo agente ativo é um redutor pouco potente (hidroxilamina), solubilizam as frações mais sensiveis do Fe na forma férrica e de Mn na forma oxidada (Barral Silva, 1987). No entanto, vários trabalhos tem mostrado uma similaridade entre as formas de $\mathrm{Mn}$ extraídos com oxalato, hidroxilamina e ditionitocitrato (Barral Silva, 1987 e Blume \& Schwertmann, 1969) e Fe extraídos com oxalato e hidroxilamina (Lee, et al. 1989; Barral Silva, 1987; Chao \& Zhou, 1983 e Ross et al., 1985), embora diferentes concentrações, temperaturas e tempo de extração dos reagentes foram utilizados.

Examinando-se os dados da Tabela 6 verifica-se que os maiores conteúdos de ferro extraído por ditionito $\left(\mathrm{Fe}_{\mathrm{d}}\right)$ estão nas glébulas, à semelhança do ferro total. Também aqui, os maiores teores são observados para as glébulas petroplínticas $(269,62 \mathrm{~g} / \mathrm{Kg})$ do perfil P2 e menores frações ocorrem na petroplintita $(215,92 \mathrm{~g} / \mathrm{Kg})$ e plintita $(149,43$ $\mathrm{g} / \mathrm{Kg}$ ) do perfil P1. Esses resultados estão de acordo com os apontamentos de Shadfan et al. (1985), os quais encontraram uma relação linear entre a resistência dos materiais ferruginosos, medidas como pressão de penetração e ferro extraido com ditionito (comparando-se F1-C com F2-C). Maiores acumulações do elemento parecem estar 
associadas com o aumento do endurecimento e resistência dos materiais (Shadfan et al., 1985), embora alguns autores afirmem que algo mais que o simples conteúdo absoluto de ferro é responsável pela habilidade de endurecer "em massa" (Alexander \& Cady, 1962 e Ibanga et al., 1983).

A distribuição em profundidade dos conteúdos de ferro total comparado ao ditionito é mostrado na Figura 20 Considerando-se que hematita e goetita foram os únicos óxidos de ferro cristalinos identificados nas análises mineralógicas, pode-se argumentar que o $\mathrm{Fe}_{\mathrm{d}}$ equivale aproximadamente ao ferro extraído desses minerais, uma vez que a fração amorfa é pouco expressiva. Sendo assim, tanto e principalmente as glébulas (Tabela 6), como a matriz interglebular, os horizontes $\mathrm{Cr}$ abaixo do ferricrete (perfis P1 e P2) e os horizontes eluviais do perfil P3 mostram-se com o ferro predominantemente nas formas oxídicas e cristalinas. No entanto, nota-se um distanciamento entre as curvas a superficie e a medida que se aprofunda no perfil, sugerindo que outras formas, que não hematita e goetita, estão presentes na fração argila e contribuem significativamente para o conteúdo de ferro total dos horizontes.

Ainda, examinando-se a Figura 20, nota-se que os maiores conteúdos de ferro total e ditionito são observados na matriz interglebular quando analisamos o perfil P1. No entanto, para o perfil $\mathrm{P} 2$, o horizonte $\mathrm{Cr}$ e camada $\mathrm{R}$ mostram teores superiores de $\mathrm{Fe}_{\mathrm{t}} \mathrm{e}$ $\mathrm{Fe}_{\mathrm{d}}$ em relação à matriz interglebular e ao solum, sugerindo uma maior influência da matriz nos horizontes inferiores e portanto, maiores mobilizações do elemento neste perfil. Essas mobilizações são prontamente evidenciadas quando analisamos os resultados do ferro e alumínio extraídos com oxalato $\left(\mathrm{Fe}_{\mathrm{o}}\right.$ e $\mathrm{Al}_{\mathrm{o}}$ ) e já foram sugeridas nas análises morfológicas, na distribuição de freqüência das areias e elementos totais.

O reagente oxalato-oxálico remove as frações amorfas dos solos e proporciona uma medida da atividade dos componentes (Schwertmann, 1973). Correspondem às frações quimicamente mais ativas dos óxidos e oxihidróxidos (Barral Silva, 1987 e Chao \& Zhou, 1983) e por isso, influenciam em algumas propriedades do solo (Barral Silva, 1987) e são passíveis de mobilidade nos horizontes e perfis (Gamble \& Daniels, 1972). Do exame da Tabela 6 nota-se que os maiores conteúdos de $\mathrm{Fe}_{\mathrm{o}}$ estão presentes nas 
glébulas. Embora este reagente reconhecidamente extrai conteúdos significativos de magnetita (Chao \& Zhou, 1983; Gamble \& Daniels, 1972; Lee et al., 1989, Rhoton et al.; 1981 e Ross, et al. 1985), pode-se desconsiderar sua contribuição aos valores de $\mathrm{Fe}_{\mathrm{o}}$, uma vez que o mineral está presente em pequena proporção. Observações micromorfológicas, submicroscópicas e de atração magnética (ímã) nas amostras (TFSA), evidenciam uma pequena e as vezes uma participação nula desse componente na fração areia e silte dos horizontes e glébulas estudados. Assim, podemos considerar aqui que o reagente oxalato-oxálico extraiu predominantemente as frações de ferro amorfas dos solos. No entanto, como veremos posteriormente, essa especificidade é menor quando se considera $\mathrm{o} \mathrm{Al}_{\mathrm{o}}$ e por isso enfatizaremos o $\mathrm{Fe}_{\mathrm{o}}$.

$\mathrm{O}$ maior conteúdo de $\mathrm{Fe}_{\mathrm{o}}$ nas glébulas é um forte argumento a corroborar as evidências de degradação e formação das glébulas. Nota-se que os maiores teores estão nas glébulas plínticas F2-C do perfil P1 $(15,12 \mathrm{~g} / \mathrm{Kg})$. Isso sugere a presença de óxidos de ferro jovens (principalmente ferridrita) em maior abundância, recentemente mobilizados e depositados na formação das plintitas e que não tiveram tempo ou talvez condições adequadas para cristalizar-se em goetita ou hematita. Por outro lado, os conteúdos também elevados de $\mathrm{Fe}_{\mathrm{o}}$ nas glébulas petroplínticas $(11,41 \mathrm{~g} / \mathrm{Kg}$ e $6,94 \mathrm{~g} / \mathrm{Kg}$ nas petroplintitas do perfil P1 e P2, respectivamente) evidenciam um novo ciclo de formação dos óxidos de ferro. Possivelmente, hematita e goetita bem cristalinizadas no interior das glébulas petroplinticas estão se dissolvendo, e uma nova geração de óxidos pouco cristalinos, tal como ferridrita, estão sendo formadas sob condições mais redutoras. Isso também conduz à formação de $\mathrm{Fe}^{2+}$ solúvel, o qual pode ser redistribuído com uma frente de umidecimento no interior do solo (Schwertmann \& Kämpf, 1983) e acumular-se abaixo, nos poros (Shadfan et al., 1985) dos fragmentos saprolíticos e rocha, juntamente com as formas amorfas. No saprolito imediatamente abaixo às glébulas, estabelecem-se condições adequadas à reoxidação do $\mathrm{Fe}^{2+}$ e recristalinização dessas formas amorfas, formando-se uma nova geração de óxidos de ferro e constituindo as feições ferruginosas aqui identificadas como plintita. 
Além do ferro, outros elementos como $\mathrm{Al}$ e principalmente $\mathrm{Si}$, são redistribuídos com a dissolução da caulinita do material petroplíntico, fato que, associado a argiluviação, ambos demonstrados anteriormente estar ocorrendo nos perfis, promovem o preenchimento da porosidade pedogenética, bem como o aumento do teor de argila nos horizontes saprolíticos. A formação e o preenchimento da porosidade nos horizontes saprolíticos com caulinita é considerado por vários autores como as etapas iniciais na formação de nódulos e concreções ferruginosas (Ambrosi \& Nahon, 1986; Bellinfante et al., 1970; Nahon, 1986 e Tardy \& Nahon, 1985). Essas transferências de matéria dos horizontes superiores e depositados nos inferiores mostram-se atuais nos perfis e sugerem uma formação contemporânea aos materiais plínticos, tal como pode-se concluir das discussões anteriores.

As condições redutoras necessárias à redução do ferro, à sua remobilização, bem como dos demais constituintes, também já foram sugeridas anteriormente. Possivelmente, os maiores conteúdos de argila nas matrizes interglebulares e a descontinuidade de poros em relação aos horizontes superficiais (perfil P1 principalmente) promovem uma hidromorfia "suspensa". No entanto, análises micromorfológicas mostram uma extensa trama de macroporos em parte da matriz saprolítica dos perfis P1 e P2, sugerindo uma maior condutividade hidráulica em relação à matriz interglebular. Assim, os constituintes passíveis de mobilidade nos horizontes petroplínticos encontram um "livre escoamento" vertical no horizonte saprolítico, até atingirem condições adequadas à sua precipitação e/ou cristalinização em alguma parte dos horizontes ou camada inferiores. Também, pode-se argumentar que uma remobilização horizontal provindos da paisagem à montante dos perfis, tal como sugerido para o manganês, são responsáveis pelo constante suprimento de ferro a essas porções inferiores da vertente. 

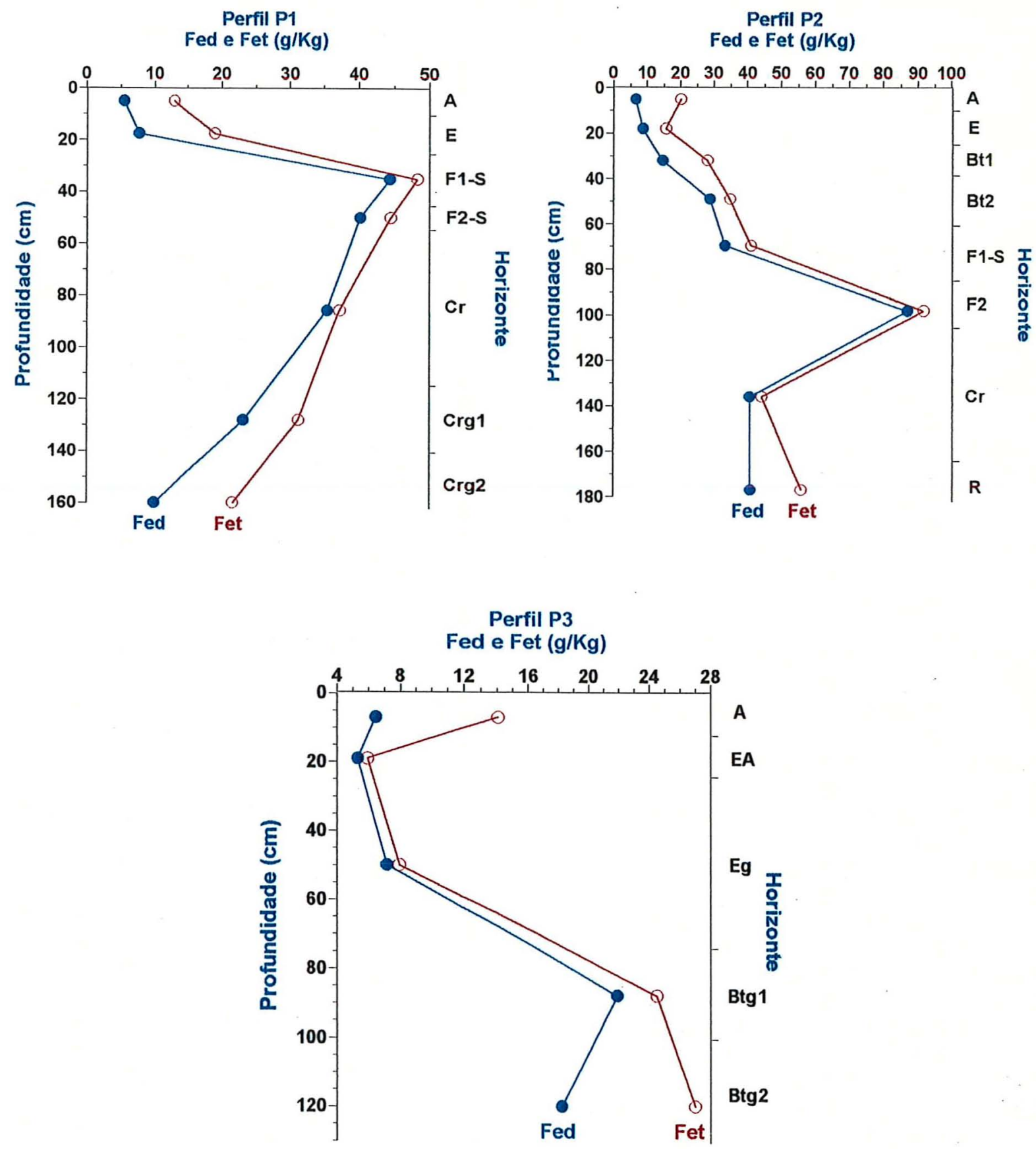

Figura 20. Distribuição, com a profundidade, do ferro total (Fet) e dos óxidos de ferro extraídos com ditionito-citrado de sódio (DC), nos perfis P1, P2 e P3 (para os horizontes ferricretes considerou-se apenas sua matriz interglebular). 
A distribuição do $\mathrm{Fe}_{\mathrm{o}}$ e da relação ferro ativo $\left(\mathrm{Fe}_{\mathrm{o}} / \mathrm{Fe}_{\mathrm{d}}\right)$ em profundidade é mostrado na Figura 21. Nela, apenas as matrizes interglebulares são consideradas no horizonte ferricrete, com exceção do horizonte F2 do perfil P2, onde as análises foram realizadas homogeneizando-se as glébulas e matriz. Da análise da Figura 21, observa-se para o perfil $\mathrm{P} 1$ que os maiores conteúdos de $\mathrm{Fe}_{\mathrm{o}}$ encontram-se na matriz interglebular, reduzindo em profundidade. Esse resultado evidencia tanto a participação de óxidos de ferro jovens oriundos da degradação das glébulas, como a mobilização deste componente nas formas pouco cristalinas e solúvel $\left(\mathrm{Fe}^{2+}\right)$, concentrando-se inicialmente na matriz interglebular e posteriormente remobilizando-se para os horizontes inferiores. Juntamente com a presença de uma cerosidade forte e abundante nos fragmentos saprolíticos do $\mathrm{Cr}$, esse maior conteúdo de $\mathrm{Fe}_{\mathrm{o}}$ em relação aos horizontes inferiores pode ser interpretado como proveniente de materiais recentemente depositados, tal como sugerem Gamble \& Daniels (1972), evidenciando mecanismos atuais de remobilizações verticais nos perfis. No entanto, as menores relações de ferro ativo são verificados nas matrizes interglebulares, horizontes $\mathrm{Cr}$ e $\mathrm{Crg} 1$. Essa relação proporciona uma indicação do conteúdo relativo de compostos de Fe pobremente ordenados ou cristalinos (Blume \& Schwertmann, 1969 e Moore, 1973). Sendo assim, apesar dos maiores teores de $\mathrm{Fe}_{\mathrm{o}}$, a relação ferro ativo evidencia que a grande proporção de Fe nesses horizontes está predominantemente na forma cristalina. Essa cristalinidade é reduzida nos horizontes superficiais A e E e no horizonte $\mathrm{Crg} 2$, possivelmente devido a diferentes fatores. Primeiro, para o horizonte $\mathrm{A}$, seu maior conteúdo de matéria orgânica pode ser responsável pela habilidade de complexar o $\mathrm{Fe}$ e estabilizar a ferridrita (a fonte primária de $\mathrm{Fe}_{\mathrm{o}}$ ), inibindo assim sua transformação para formas mais estáveis de óxidos de ferro (Schwertann \& Taylor, 1989). No entanto, no horizonte E, a presença de uma maior relação $\mathrm{Fe}_{\mathrm{d}} / \mathrm{Fe}_{\mathrm{d}}$ pode ser interpretado como conseqüência dos processos envolvidos na eluviação das argilas e gênese do próprio horizonte. Assim, parte do ferro presente neste horizonte (ferro amorfo) é potencialmente capaz de mobilizar-se aos horizontes inferiores ou às porções mais baixas da paisagem, tal como sugerido por Blume \& Schwertmann (1969). Esses autores, referindo-se à mobilidade do ferro, afirmam que as únicas frações 
móveis nos solos são aquelas solúveis em oxalato-oxálico. A máxima expressão dessa tendência é verificada no horizonte $\mathrm{E}$ do perfil $\mathrm{P}$ 3, onde a relação ferro ativo é a maior entre todos os horizontes estudados $(21,84 \%)$.

Outro fator possivelmente envolvido no aumento da relação $\mathrm{Fe}_{\mathrm{o}} / \mathrm{Fe}_{\mathrm{d}}$ no horizonte Crg2 (perfil P2) refere-se à liberação do ferro de outras fontes que não hematita e goetita, fato que, associado a migração descendente de compostos amorfos e $\mathrm{Fe}^{2+}$, bem como ao lento envelhecimento a baixos valores de $\mathrm{pH}$, podem ser a razão para o maior conteúdo relativo de óxidos de ferro amorfos (Blume \& Schwertmann, 1969). O Fe ${ }^{2+}$ solúvel, mobilizado dos horizontes ferricretes superiores, encontra potenciais adequados para sua oxidação nos horizontes saprolíticos abaixo, podendo originar compostos pouco cristalinos (ferridrita) dependendo das condições de sua formação, tal como sugerido por Schwertmann \& Kämpf (1983). Assim, tanto as taxas de oxidação lenta (Schwertmann \& Kämpf, 1983) como as maiores concentrações de Al (Schwertann \& Taylor, 1989) são favoráveis a produção de ferridrita e podem ser os principais responsáveis pelos maiores valores de ferro ativo no horizonte $\mathrm{Crg} 2$, uma vez que este perfil encontra-se permanentemente saturado na estação chuvosa e mostra elevados conteúdos de alumínio trocável $\left(38 \mathrm{mmol}_{\mathrm{c}} / \mathrm{dm}^{3}\right)$.

Examinando-se o perfil P2 (Figura 21) nota-se que os teores de $\mathrm{Fe}_{\mathrm{o}}$ aumentam em profundidade, alcançando o máximo valor no horizonte F2 e a partir daí mantendo-se praticamente constante no horizonte $\mathrm{Cr}$ e camada $\mathrm{R}$. Comparativamente ao perfil $\mathrm{P} 1$, os maiores valores de $\mathrm{Fe}_{\mathrm{o}}$ nessas porções inferiores do $\mathrm{P} 2$ sugerem mobilizações mais significativas de ferro neste perfil, tal como evidenciado anteriormente, e principalmente a influência do Al na formação e manutenção de óxidos de ferro jovens (ferridrita), pois é na rocha que encontra-se o maior e bastante significativos conteúdos de Al trocável (115 $\mathrm{mmol}_{\mathrm{c}} / \mathrm{dm}^{3}$ ) entre todos os perfis estudados (Tabela 6). A relação ferro ativo mostra uma tendência similar ao perfil P1 e portanto, basicamente as mesmas interpretações auferidas do $P 1$ são repetidas aqui. Assim, maiores valores da relação $\mathrm{Fe}_{\mathrm{o}} / \mathrm{Fe}_{\mathrm{d}}$ tanto no horizonte $\mathrm{A}$ como no horizonte $\mathrm{E}$, são devido ao seu maior conteúdo de matéria orgânica, bem como aos fatores envolvidos na gênese dos horizontes $B$ texturais $e$, principalmente dos 
horizontes superficiais (A e E). Tal como sugerido por Lepsch et al. (1977b), a desestabilização dos agregados e colocação da argila em suspensão são conseqüências da liberação do ferro dessa argila, promovendo assim sua eluviação. Portanto, as formas amorfas nos horizontes E, Bt1 e Bt2 podem ser aqui interpretadas como dissociadas das argilas silicatadas e passiveis de mobilidade para os horizontes inferiores do perfil, e por isso, a relação ferro ativo é maior no horizonte $E$, reduzindo nos horizontes texturais. Isso indica uma maior "disposição" à mobilização do ferro no horizonte $\mathrm{E}$.

Os valores de $\mathrm{Fe}_{\mathrm{o}}$ e $\mathrm{Fe}_{\mathrm{o}} / \mathrm{Fe}_{\mathrm{d}}$ para o perfil $\mathrm{P} 3$ (Figura 21) são maiores em relação aos demais perfis. Outros trabalhos mostram resultados similares, evidenciando o efeito do hidromorfismo no aumento da relação ferro ativo (Moore, 1973 e Schwertmann \& Kämpf, 1983). Segundo Schwertmann \& Kämpf (1983), o ferro da goetita e hematita pode ser remobilizado caso os solos que os contenham sejam submetidos a condições redutoras. Isso conduz a formação de $\mathrm{Fe}^{2+}$ solúvel, o qual pode ser redistribuído com a água no interior do solo e, pela reoxidação, formam-se novos tipos óxidos de ferro, tais como ferridrita e lepidocrocita mal cristalinizada. Essas duas formas são reconhecidamente fontes de ferro amorfos (Barral Silva, 1987 e Partiff \& Childs, 1988) e o mecanismo enunciado acima pode estar ocorrendo aqui, contribuindo tanto para os maiores conteúdos de $\mathrm{Fe}_{\mathrm{o}}$ como para a maior relação ferro ativo comparativamente aos demais perfis estudados, sugerindo principalmente maiores conteúdos de ferridrita Lepidocrocita parece estar associada com um macroclima caracterizado por uma precipitação média anual elevada e temperaturas médias relativamente baixas (Fitzpatrick et al., 1985) e portanto, são raras as referências desse mineral nos materiais gleizados das regiões tropicais (Barral Silva, 1987).

Dos enunciados acima podemos inferir e corroborar a presença de dois mecanismos distintos e complementares, os quais são atuantes nos perfis P1 e P2. Os processos pedogenéticos de transferência de matéria parecem estar envolvidos na gênese dos horizontes superficiais franco arenosos e horizontes $B$ texturais, ao passo que o processo de "ferricretização", aparentemente foi responsável pelo desenvolvimento dos horizontes ferricretes e influencia sobremaneira nos atributos fisicos, morfológicos e 
mineralógicos dos horizontes saprolíticos abaixo. Assim, podemos argumentar que gênese dos solos acima dos horizontes ferricretes é poligenética, ou seja, influenciada por diferentes fases de pedogênese. Colúvio, e-iluviação de argila e degradação do horizonte petroplíntico fornecendo ferro para a formação da plintita, bem como contribuindo para a formação dos horizontes acima, aparentam mecanismos efetivos nos perfis estudados. Maiores detalhes serão fornecidos nas discussões micromorfológicas e gênese dos ferricretes. 

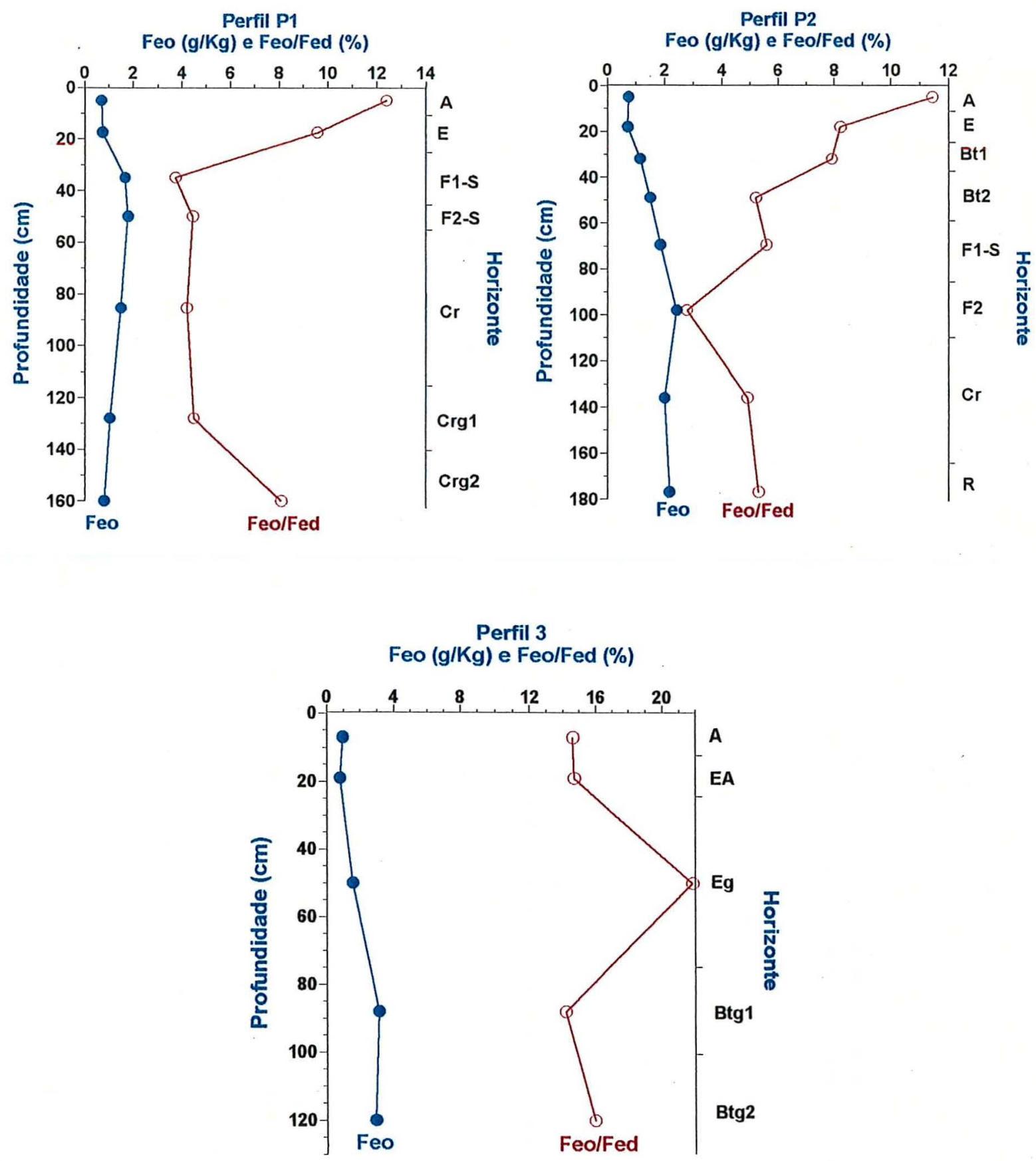

Figura 21. Distribuição em profundidade do ferro extraído com oxalato-oxálico $\left(\mathrm{Fe}_{\mathrm{o}}\right)$ e da relação "ferro ativo" $\left(\mathrm{Fe}_{\mathrm{o}} / \mathrm{Fe}_{\mathrm{d}}\right.$ ) para os perfis P1, P2 e P3 (para os horizontes ferricretes, considerou-se apenas sua matriz interglebular). 
Os resultados de ferro extraido com os reagentes hidroxilamina $\left(\mathrm{Fe}_{\mathrm{h}}\right)$ e pirofosfato $\left(\mathrm{Fe}_{\mathrm{p}}\right)$ também estão apresentados na Tabela 6. Ao contrário dos resultados obtidos por Barral Silva (1987), Chao \& Zhou (1983), Lee, et al. (1989) e Ross et al. (1985), as determinações de $\mathrm{Fe}_{\mathrm{h}}$ aqui encontradas foram consideravelmente inferiores ao $\mathrm{Fe}_{\mathrm{o}}$. Esses autores encontraram uma significativa, mas pequena diferença entre os diferentes extratores $\left(\mathrm{Fe}_{\mathrm{o}}>\mathrm{Fe}_{\mathrm{h}}\right)$, atribuindo esse resultado à maior seletividade do reagente hidroxilamina, principalmente quando as amostras analisadas apresentavam apreciáveis conteúdos de magnetita. No entanto, essa interpretação não é adequada para presente trabalho devido ao baixo conteúdo desse mineral presente nos horizontes, pouco contribuindo aos valores do extrato oxalato-oxálico. Embora diferentes concentrações dos extratores estejam envolvidos nas metodologias utilizadas, bem como diferentes tempo de extração e relação solo:extrator, a divergência entre os resultados não pode ser atribuído a essas variações, pois há uma coerência nelas (exemplo: para uma maior concentração de $\mathrm{HCl}$ utilizou-se um menor tempo de extração) e portanto, desconhece-se suas causas. Da análise da Tabela 6 observa-se que os maiores conteúdos de $\mathrm{Fe}_{\mathrm{h}}$ estão nas glébulas. A semelhança do $\mathrm{Fe}_{\mathrm{o}}$, também as plintitas do perfil P1 (F2-C) mostram os maiores teores das formas facilmente redutiveis e portanto, as mesmas interpretação podem ser sugeridas aqui. Em relação as matrizes interglebulares, horizontes e camadas dos perfis, o maior teor de $\mathrm{Fe}_{\mathrm{h}}$ é verificado para a rocha $(0,48 \mathrm{~g} / \mathrm{Kg})$ do perfil P2. Certamente, o mecanismo de ferrólise é principal responsável pelo suprimento de ferro na forma facilmente redutível a essa camada, tal como evidenciado anteriormente.

$\mathrm{O}$ ferro extraido com o reagente pirofosfato de sódio $\left(\mathrm{Fe}_{\mathrm{p}}\right)$ possibilita uma estimativa do elemento associado a compostos orgânicos e tem sido usado por alguns autores, principalmente nos estudos de gênese e classificação dos solos podzois, tal como sugerido por McKeague et al. (1971). Esses autores encontraram que o reagente pirofosfato extraiu pouco ferro das substâncias amorfas inorgânicas e cristalinas. No entanto, trabalhos mais recentes (Partiff \& Childs, 1988, p.121) afirmam que o $\mathrm{Fe}_{\mathrm{p}}$ "não especificamente está relacionado a alguma forma particular de Fe nos solos e deveria não ser usado para estimá-lo nos complexos húmicos." Outros ainda, como Costa (1996) e 
Schwertmann (1973), consideram que o reagente oxalato-oxálico também remove a maior parte do Fe orgânico. Em vista do exposto, os resultados obtidos com o reagente pirofosfato devem ser tratados com cautela. No entanto, algumas observações interessantes podem ser inferidas aqui

Ao analisarmos a Figura 22 (variação do $\mathrm{Fe}_{\mathrm{o}}$ e $\mathrm{Fe}_{\mathrm{p}}$ em profundidade), observa-se que há uma tendência de diminuição do $\mathrm{Fe}_{\mathrm{p}}$ em profundidade, acompanhando aproximadamente a variação do conteúdo de matéria orgânica. Também, observa-se nos primeiros $40 \mathrm{~cm}$ de profundidade para todos os perfis, que o valor de $\mathrm{Fe}_{\mathrm{o}}$ é aproximadamente semelhante ao $\mathrm{Fe}_{\mathrm{p}}$, e até mesmo inferior nos horizontes $\mathrm{A}$ e $\mathrm{E}$ do perfil P1, horizonte E do perfil P2 e horizontes A do P3. Considerando-se que o reagente pirofosfato é seletivo para as formas associadas a matéria orgânica e que o oxalatooxálico também é extrator dessas formas, podemos inferir que a movimentação do ferro no solum acima do horizonte ferricrete para os perfis P1 e P2 e nos primeiros $50 \mathrm{~cm}$ do perfil P3 é devido à sua associação a compostos húmicos. Portanto, as considerações apontadas acima de que os maiores conteúdos da relação ferro ativo nos horizontes $\mathrm{E}$ de todos os perfis são conseqüências dos processos envolvidos na gênese do próprio horizonte $\mathrm{E}$, bem como dos horizontes texturais, poderiam ser desconsideradas, pois a movimentação do ferro nesses horizontes estaria associada aos compostos húmicos $\mathrm{e}$ certamente, esse não é o principal mecanismo envolvido na gênese desses solos. Essa variação do $\mathrm{Fe}_{\mathrm{p}}$ acompanhando aproximadamente as variações no conteúdo de matéria orgânica nos perfis, bem como os baixos valores extraídos das glébulas comparativamente ao valores de $\mathrm{Fe}_{\mathrm{o}}$ (Tabela 6), sugerem uma certa especificidade ao extrator pirofosfato, bem como uma notável influência da movimentação do ferro associado aos compostos húmicos no solum $\left(\mathrm{Fe}_{\mathrm{p}} \cong \mathrm{Fe}_{\mathrm{o}}\right)$ e a predominância das mobilizações do elemento na forma inorgânica para os horizontes saprolíticos abaixo dos ferricretes e horizontes texturais do $\mathrm{P} 3 \quad\left(\mathrm{Fe}_{\mathrm{o}}>\mathrm{Fe}_{\mathrm{p}}\right)$. Fatores esses que novamente corroboram uma provável especificidade do pirofosfato, uma vez que os menores teores de matéria orgânica nas porções inferiores dos perfis favorecem as mobilizações inorgânicas, tal como evidenciado na Figura 22, onde os valores de $\mathrm{Fe}_{\mathrm{o}}$ são muito 
superiores ao $\mathrm{Fe}_{\mathrm{p}}$. Apesar das evidências favoráveis a especificidade do pirofosfato, Partiff \& Childs (1988) desencorajam o uso do reagente para formas associadas a matéria orgânica e portanto, reafirma-se aqui que os resultados e interpretações acima devem ser considerados com cautela. 

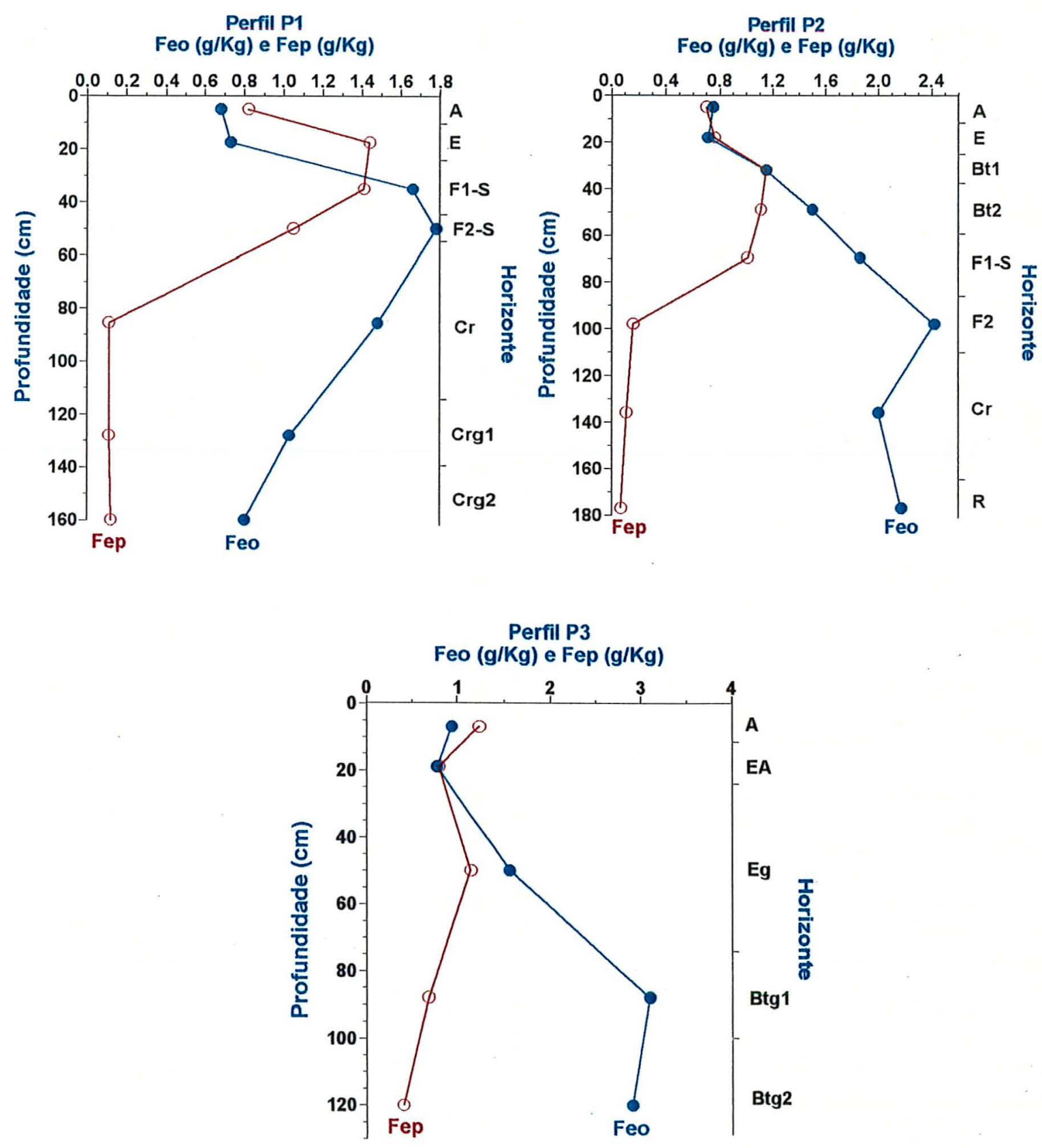

Figura 22. Distribuição em profundidade do ferro extraído pelos reagentes oxalato-oxálico $\left(\mathrm{Fe}_{\mathrm{o}}\right)$ e pirofosfato $\left(\mathrm{Fe}_{\mathrm{p}}\right.$ ) para os perfis P1, P2 e P3 (para os horizontes ferricretes considerou-se apenas sua matriz interglebular). 
Os conteúdos de alumínio total $\left(\mathrm{Al}_{\mathrm{t}}\right)$, ditionito $\left(\mathrm{Al}_{\mathrm{d}}\right)$ e oxalato $\left(\mathrm{Al}_{\mathrm{o}}\right)$ estão representados na Tabela 6 e a variação do $\mathrm{Al}_{\mathrm{d}}$ e $\mathrm{Al}_{\mathrm{o}}$ em profundidade são mostrados na Figura 23. Nota-se que os valores de $\mathrm{Al}_{\mathrm{t}}$ extraido com $\mathrm{H}_{2} \mathrm{SO}_{4}$ são muito superiores ao $\mathrm{Al}$ extraído com ditionito-citrato e oxalato-oxálico. Esses resultados são condizentes aos encontrados por Anjos (1995) e Barral Silva (1987) para solos contendo diferentes feições ferruginosas. $\mathrm{Da}$ análise da Figura 23 nota-se que o valor de $\mathrm{Al}_{d}$ foi significativamente superior ao $\mathrm{Al}_{0}$, apenas invertendo essa situação na rocha $(R)$ do perfil $\mathrm{P} 2$, bem como valores muito próximos são observados no horizonte Crg2 do perfil P1 e Cr do perfil P2. Possivelmente, alguma mobilização do alumínio liberado da degradação da caulinita no ferricrete pode ser considerado aqui, contribuindo para o aumento no conteúdo do elemento na rocha. No entanto, esse mecanismo mostra-se pouco significativo, tal como demostrado anteriormente nas análises de elementos totais. Sugere-se aqui que tanto o elevado conteúdo de $\mathrm{Al}_{\mathrm{o}}$ presente na rocha, bem como a sua proximidade aos valores de $\mathrm{Al}_{\mathrm{d}}$, são resultados do maior conteúdo de minerais silicatados de baixa cristalinidade, principalmente caulinita, tal como sugerido por McKeague \& Day (1966). Os autores encontraram que muito mais Al foi removido pelo extrator oxalatooxálico que por DC para materiais Al-Si amorfos, embora Partiff \& Childs (1988) demostraram que o oxalato não dissolveu aluminossilicatos. Possivelmente, os solos utilizados por esses últimos autores não continham elevados conteúdos desses constituintes silicatados amorfos. Barral Silva (1987) também argumenta que a extração do alumínio com oxalato pode provocar a solubilização do Al interlaminar dos filossilicatos. Aqui, podemos considerar que a ferrólise é responsável por desestabilizar a estrutura da caulinita, fato que, associado ao intemperismo dos minerais primários, principalmente feldspatos, bem como a mobilização de silício provindo da degradação das glébulas, contribuem para a formação de compostos silicatados de baixa cristalinidade e esses para os elevados teores de $\mathrm{Al}_{0}$. Portanto, o reagente oxalato-oxálico é o extrator mais efetivo das formas amorfas de alumínio.

Embora o extrator DC remova parte do Al da gibbsita (Buurman et al. 1996) foi comentado aqui que as condições são inadequadas a formação deste mineral (elevado 
conteúdo de $\mathrm{Si}$ ), bem como, apenas pequenas proporções de gibbsita foi identificado nas análises mineralógicas e submicroscópicas. Assim, o Al dissolvido no ditionito-citrato provavelmente provém, em parte, da substituição isomórfica do elemento na estrutura da hematita e goetita (Barral Silva, 1987; Partiff \& Childs, 1988 e Shadfan et al., 1985). Barral Silva et al. (1988) consideram que a ordem de extratibilidade $\mathrm{Al}_{\mathrm{d}}>\mathrm{Al}_{\mathrm{o}}$ tem que ser atribuído a substituições aluminosas nas formas cristalinas de ferro, fato que tem sido comprovado aqui por difração de raio-x. Podemos antecipar, pela análise da relação $\mathrm{Al}_{d} / \mathrm{Fe}_{\mathrm{d}}$ (Tabela 6), que os óxidos de ferro (hematita e goetita) presentes nas glébulas são pouco aluminosos. Essa relação nos fornece uma indicação da quantidade de $\mathrm{Al}$ presente nos óxidos de ferro, uma vez que o extrator DC remove principalmente essas formas do solo. Maiores detalhes serão discutidos na análise dos resultados mineralógicos, pois em se tratando de amostras que contenham tanto hematita como goetita, tais como encontradas em nosso trabalho, esses valores de dissoluções seletivas para avaliar o grau de substituição por alumínio nos óxidos de ferro mostram-se muito variáveis (Shadfan et al., 1985). 

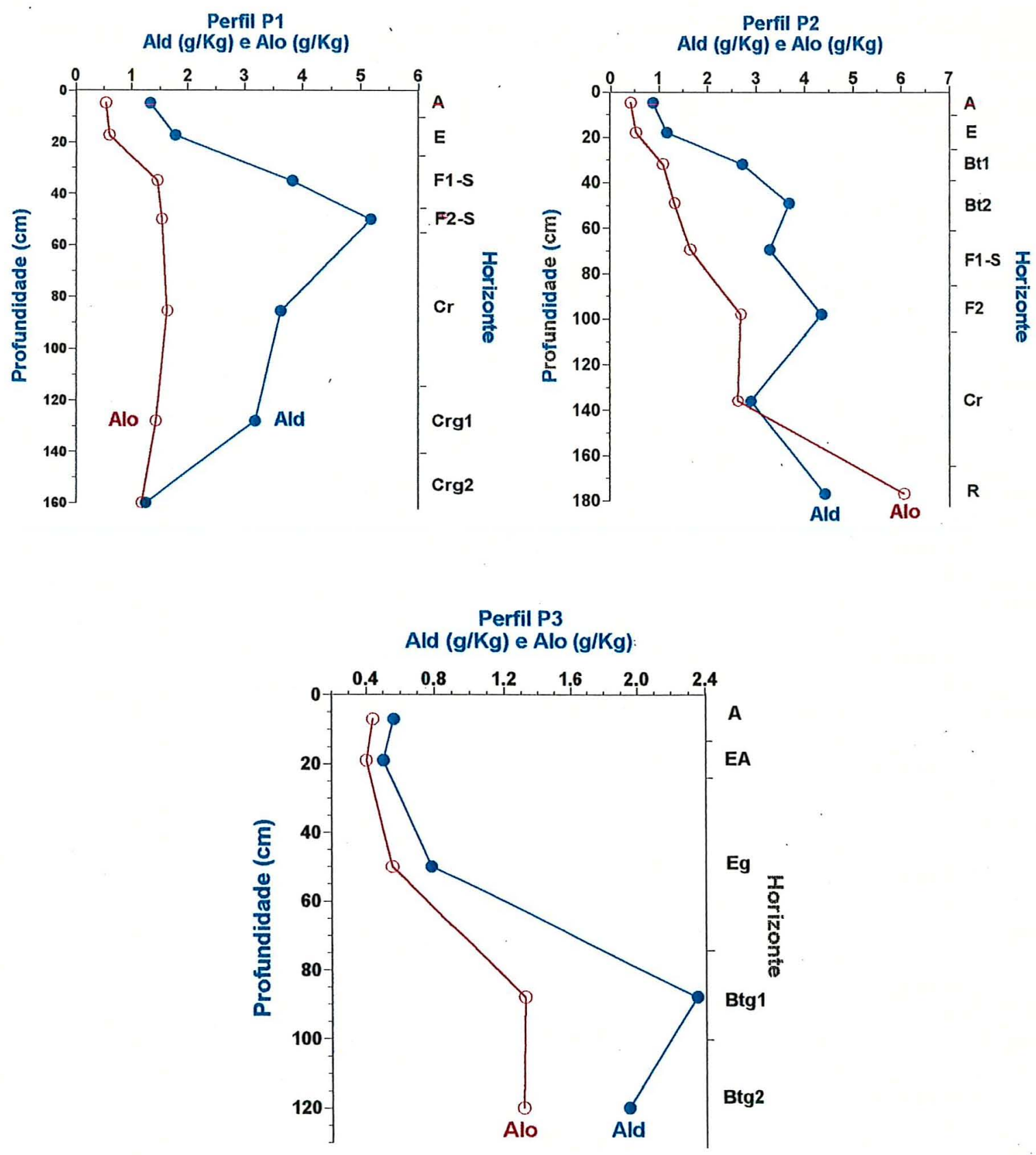

Figura 23. Distribuição em profundidade do alumínio ditionito $\left(\mathrm{Al}_{\mathrm{d}}\right)$ e oxalato $\left(\mathrm{Al}_{\mathrm{o}}\right)$ para os perfis P1, P2 e P3 (para os horizontes ferricretes considerou-se apenas sua matriz interglebular) 
$\mathrm{O}$ conteúdo de manganês extraído com DC, oxalato-oxálico e hidroxilamina são mostrados na Tabela 6 . Analisando-se o elemento nas glébulas em suas diferentes formas, nota-se que os maiores valores são observados para o manganês na sua forma cristalina, identificados na tabela como $\mathrm{Mn}_{\mathrm{d}}$. Teores similares são encontrados para as diferentes glébulas nos perfis. No entanto, há uma variação considerável nos conteúdos de $\mathrm{Mn}_{0}$, embora essa forma encontra-se em pequenas proporções em relação ao $\mathrm{Mn}_{\mathrm{d}}$. Por analogia ao ferro solúvel em oxalato-oxálico, o manganês extraído com esse reagente pode ser considerado como amorfo (Barral Silva, 1987 e Barral Silva et al., 1988). Sendo assim, maiores conteúdos amorfos do elemento estão presentes nas glébulas plínticas do perfil P1 (F2-C), à semelhança ao ferro. Portanto, tal como sugerido acima para os compostos de ferro, as recentes deposições e formação dessas feições são responsáveis pela jovialidade e portanto baixa cristalinidade dos compostos manganíferos. Essas variações entre as glébulas plínticas e petroplínticas são menos significativas para o extrator hidroxilamina e mostram resultados superiores em relação ao oxalato-oxálico.

A distribuição em profundidade dos diferentes compartimentos de manganês $\left(\mathrm{Mn}_{\mathrm{d}}, \mathrm{Mn}_{\mathrm{o}}\right.$ e $\left.\mathrm{Mn}_{\mathrm{h}}\right)$ são representados na Figura 24. Observa-se para o perfil P1 que os maiores conteúdos do elemento são observados para o horizonte $\mathrm{A}$, bem como os valores de $\mathrm{Mn}_{\mathbf{h}}$ são superiores, embora próximos, aos valores de $\mathrm{Mn}_{\mathfrak{d}}$ e $\mathrm{Mn}_{\mathbf{0}}$. Isso possivelmente está relacionado a recente movimentação e complexação do elemento a compostos húmicos, mantendo-o amorfo e passível de mobilidade no sistema, bem como à sua biociclagem, uma vez que o manganês é um nutriente essencial às plantas. Essa mobilidade e escassa cristalinidade é confirmada pela similaridade na capacidade de extração que apresentam os extratores oxalato-oxálico e ditionito-citrato (Barral Silva, 1987). Valores similares entre esses três extratores são mostrados no trabalho de Barral Silva (1987). No entanto, observa-se que cristalinidade dos óxidos de manganês $\left(\mathrm{Mn}_{\mathrm{d}}>\mathrm{Mn}_{\mathrm{o}}\right.$ e $\left.\mathrm{Mn}_{\mathrm{h}}\right)$ é maior nas matrizes interglebulares, mantendo-se aproximadamente constante até o horizonte $\mathrm{Crg} 1$, sugerindo pequenas mobilizações do elemento neste perfil. No horizonte $\mathrm{Crg} 2$, as formas móveis facilmente redutiveis aumentam, reduzindo as oxidadas, possivelmente devido as condições reductomórficas a que periodicamente 
submetem essa porção do perfil, removendo parte do manganês oxidado (menor $\mathrm{Mn}_{\mathfrak{d}}$ ) e colocando-o na forma móvel, facilmente redutível.

Analisando-se o perfil P2 (Figura 24), observa-se os maiores conteúdos de manganês entre todos os perfis. Como comentado anteriormente, o elemento mobilizado das porções a montante do perfil, encontram potenciais de oxidorredução adequados no horizonte $\mathrm{Cr}$ e camada $\mathrm{R}$ do $\mathrm{P} 2$, formando películas nos fragmentos saprolíticos e mangãs na porosidade fissural. No entanto, nota-se que as formas facilmente redutiveis $\left(\mathrm{Mn}_{\mathrm{h}}\right)$ são consideravelmente superiores às formas cristalinas $\left(\mathrm{Mn}_{\mathrm{d}}\right)$ e amorfas $\left(\mathrm{Mn}_{\mathbf{0}}\right)$, sugerindo que o elemento está pouco cristalinizado e móvel. Portanto, ou foram recentemente depositados e ainda não tiveram tempo para cristalinizar-se, ou as condições de Eh e pH não possibilitam sua cristalinização. $O$ certo é que a capacidade redutora do extrator hidroxilamina sobrepôs-se ao efeito complexante e redutor dos reagentes ditionito-citrato e oxalato-oxálico, removendo maiores conteúdos de $\mathrm{Mn}$ de baixa cristalinidade. Teores similares entre os três extratores são observados desde o horizonte A até o horizonte F2, sugerindo formas pouco cristalinas de manganês por todo o perfil $\mathrm{P} 2$, fato que, associado aos maiores teores do elemento nas formas oxalato-oxálico e facilmente redutiveis, evidenciam as maiores mobilizações de elementos neste perfil em relação aos demais aqui estudados, tal como relatado para o ferro.

Para o perfil P3, observa-se as maiores proximidades entre as diferentes formas de manganês. No entanto, o maior conteúdo de matéria orgânica no horizonte A e entre todos os horizontes estudados, condicionou a complexação do elemento, e vem a corroborar a afinidade do extrator hidroxilamina para essas formas do elemento associado a compostos húmicos. Verifica-se a maior proximidade entre todos as formas de Mn nos horizonte EA e E, sugerindo tanto uma menor influência da matéria orgânica, como as condições de mobilidade que se encontram o elemento neste horizonte. A partir dai e aprofundando-se no perfil, as formas cristalinas $\left(\mathrm{Mn}_{\mathrm{d}}\right)$ são superiores as formas amorfas e facilmente redutiveis. Isso é acompanhado pelo aumento das condições redutoras, promovendo assim, a remoção dos compostos de baixa cristalinidade. 
Os resultados de dissoluções seletivas evidenciam a influência da degradação das glébulas na sua matriz friável, bem como nos horizontes e camada abaixo, originando as plintitas macias com menores conteúdos de ferro cristalinos e maiores teores de materiais amorfos. 
Perfil P1

Mnd, Mno e Mnh $(\mathrm{mg} / \mathrm{Kg})$

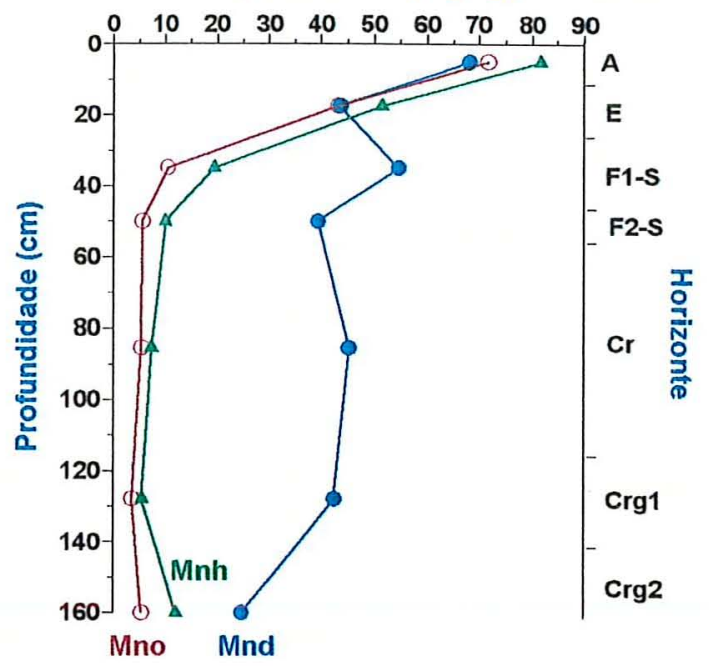

Perfil P2

Mnd, Mno e Mnh (mg/Kg)

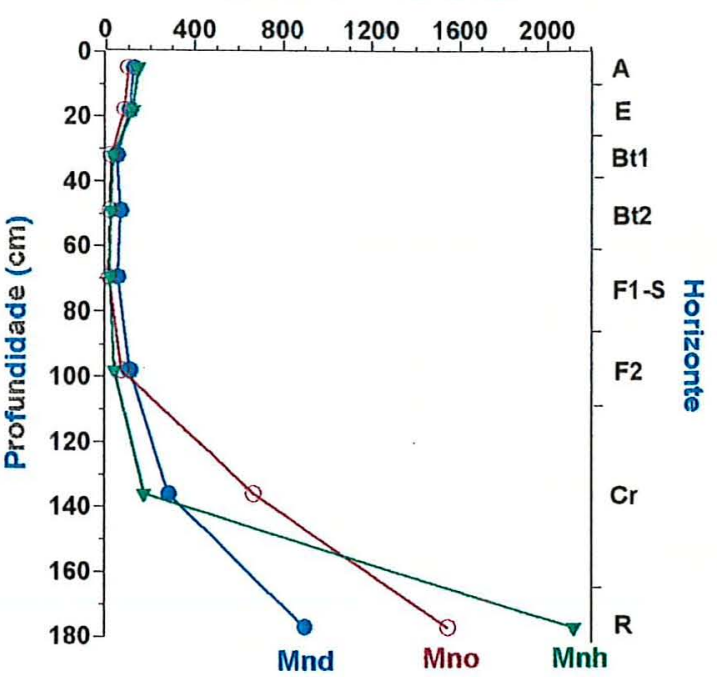

Perfil P3

Mnd, Mno e Mnh (mg/Kg)

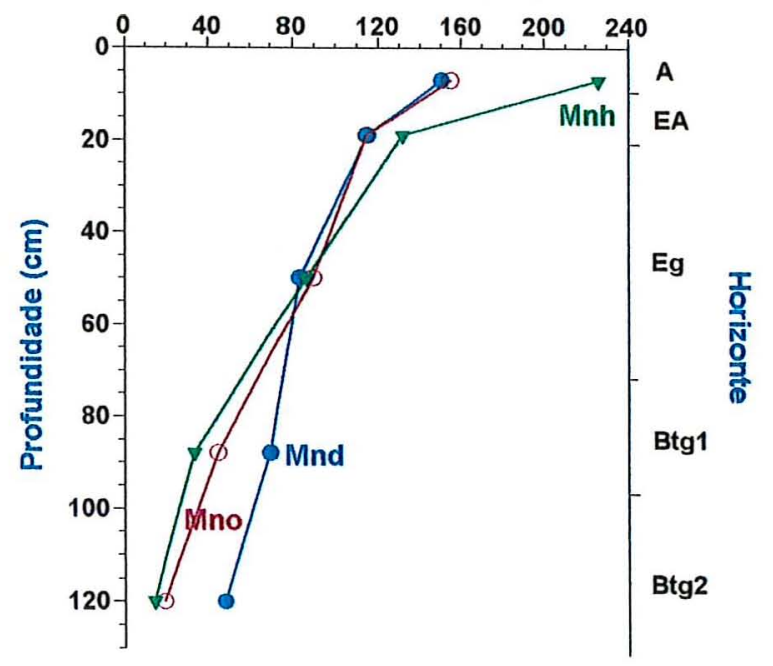

Figura 24. Distribuição em profundidade do manganês extraído como ditionito-citrato $\left(\mathrm{Mn}_{\mathrm{d}}\right)$, oxalato-oxálico $\left(\mathrm{Mn}_{\mathrm{o}}\right)$ e hidroxilamina $\left(\mathrm{Mn}_{\mathrm{h}}\right)$ para todos os perfis estudados (para o horizonte ferricrete considerou-se apenas sua matriz interglebular). 


\subsection{Evidências mineralógicas}

A seguir serão caracterizados as glébulas e os diferentes horizontes dos perfis estudados, possibilitando informações complementares e adicionais ao estudo da gênese dos ferricretes.

\subsubsection{Mineralogia da fração argila desferrificada}

Na Figura 25 estão apresentados os difratogramas das glébulas petroplinticas F1C para os perfis P1 e P2 e plinticas F2-C para o perfil P1. Observa-se que as glébulas mostraram uma idêntica mineralogia, apenas diferindo-se pela presença de traços de gibbsita na amostra petroplíntica do perfil P1, tal como confirmado nas observações submicroscópicas. No entanto, podemos afirmar confrontando os dados de intensidade dos picos (espaçamento $\mathrm{d}=7,18 \AA$ e $3,58 \AA$ ) e do conteúdo de silício e alumínio totais (Tabela 6), que teores similares de caulinita estão presentes nas glébulas plínticas e petroplínticas do perfil P1, porém observa-se que o mineral está em menores proporções na petroplintita do $\mathbf{P} 2$. Isso corrobora os resultados apresentados anteriormente (análise dos elementos totais), ou seja, a maior acumulação de ferro neste horizonte é responsável pela dissolução da caulinita (Ambrosi et al., 1986; Beauvais \& Tardy 1991; Muller \& Bocquier, 1986 e Nahon, 1991). Além desses minerais, também mica é outro componente da fração argila das glébulas. Composições similares podem ser encontradas nos ferricretes estudados por Ibanga (1980).

Assim, caulinita, mica e traços de gibbsita são os minerais da fração argila nas glébulas, identificados no raio-x após remoção dos óxidos de ferro com ditionito de sódio. As amostras petroplínticas (F1-C) do P2 mostram um pico de goetita devido a incompleta remoção do mineral durante o preparo das amostras. Gibbsita é autigênica e sua formação será discutida na interpretação dos resultados de microscopia eletrônica de varredura. Esse mineral geralmente está presente em pequenas proporções (Tardy, 1993) e foi identificado por vários autores na composição mineralógica dos ferricretes (Beauvais, et al. 1990; Beauvais \& Colin, 1993; Beauvais \& Roquin, 1996; Tardy 1993; Tardy \& Roquin, 1992 e Roquin et al., 1990b). 


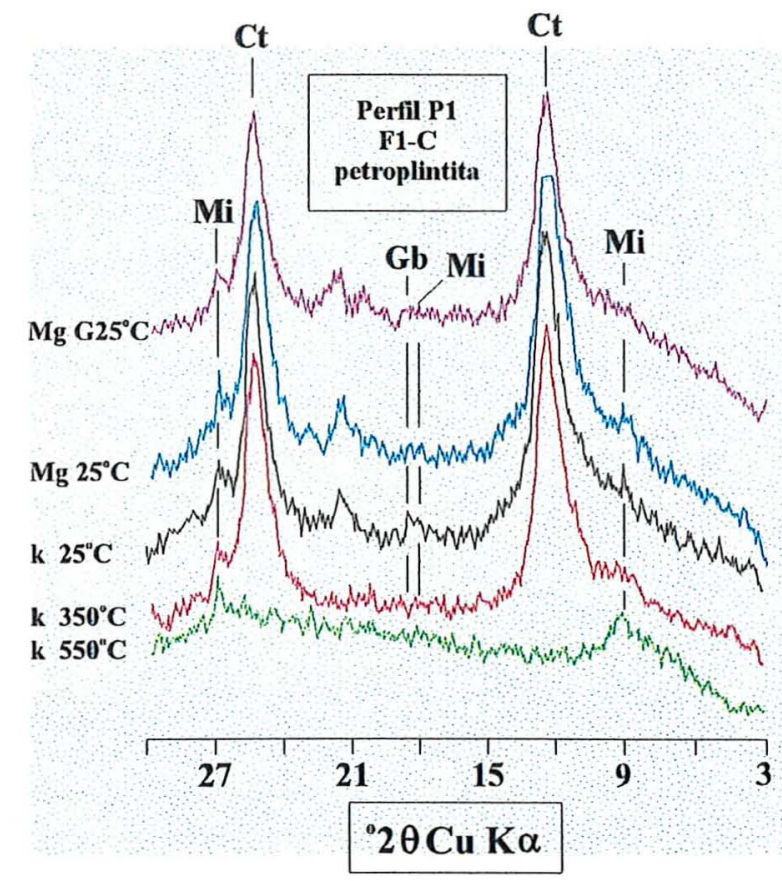

\section{Glébullas}

\section{Mi: mica \\ Ct: caulinita \\ Gb: gibbsita \\ Gt: goetita}
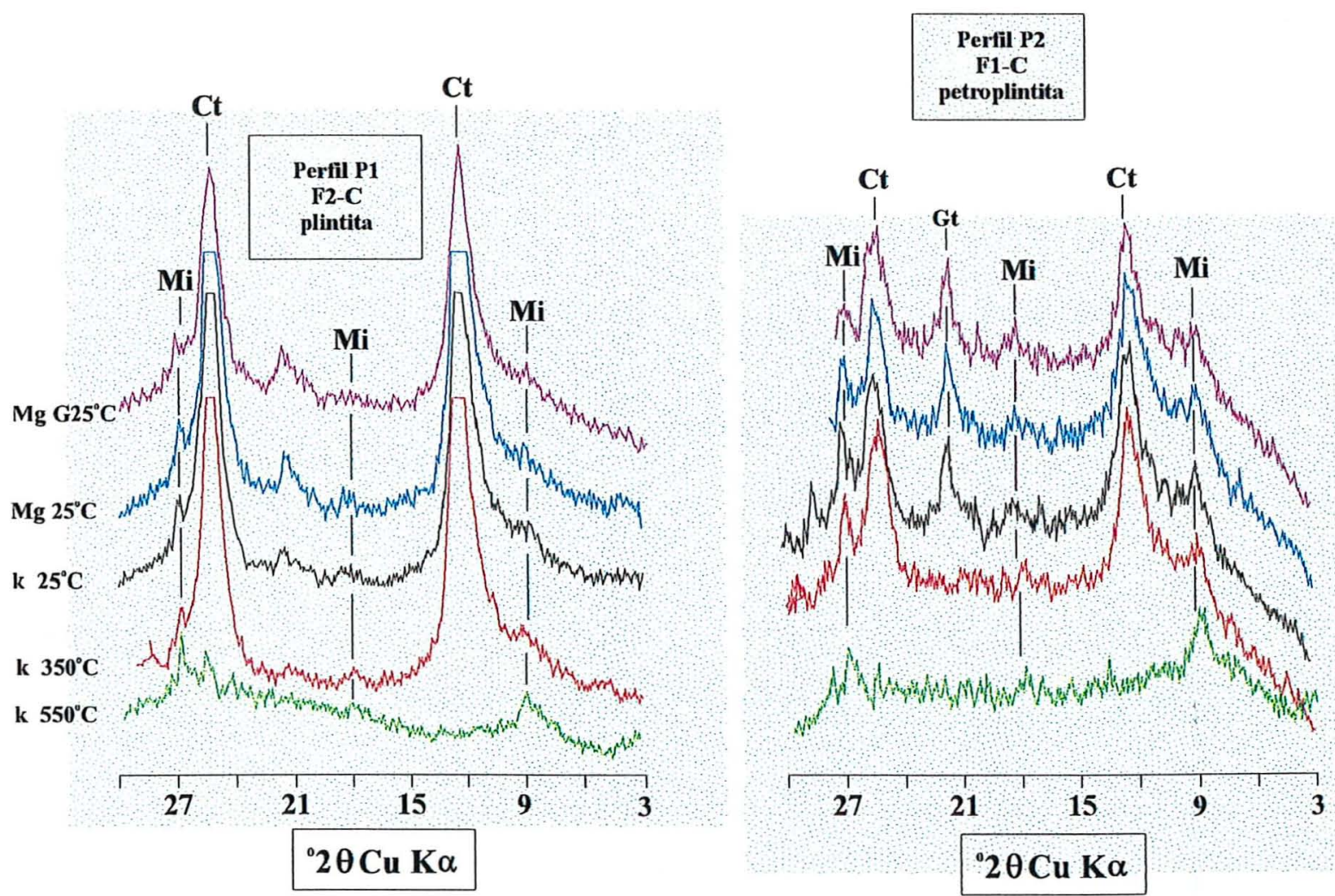

Figura 25: Difratogramas de raio-x da fração argila desferrificada das glébulas petroplínticas (F1-C) dos perfis P1 e P2 e plínticas (F2-C) do P1. 
A Figura 26 mostra os difratogramas dos horizontes e camada dos três perfis estudados. Mineralogia idêntica às glébulas são observadas nos diferentes horizontes dos perfis estudados. A Tabela 7 foi obtida a partir da intensidade dos picos e teores de $\mathrm{Si}$ e $\mathrm{Al}$ totais e nos dá uma idéia do conteúdo relativo dos minerais silicatados e gibbsita na fração argila. Observa-se que o mineral gibbsita está presente apenas em pequenas proporções e principalmente no solum e matriz interglebular (F1-S e F2-S). Possivelmente as condições de drenagem livre são suficientes para induzir um intemperismo mais acelerado, fato que, associado a uma menor atividade termodinâmica da sílica e maior atividade da água (Tardy \& Roquin, 1992 e Tardy \& Novikoff, 1988) quando comparado os horizontes saproliticos e rocha abaixo (perfis P1 e P2), promovem a transformação da caulinita (mineral desidratado) em gibbsita (mineral hidratado) (Tardy \& Novikoff, 1988). No entanto, podemos argumentar que as condições gerais para estabilização dos minerais em todos os horizontes nos perfis estudados são favoráveis a manutenção da caulinita em detrimento da gibbsita, e por isso, encontra-se apenas em pequenas proporções no solum e matriz interglebular. Essas condições desfavoráveis são provavelmente devido ao fato desses solos conterem elevado conteúdo de areia fina, a qual pode liberar Si na solução, o suficiente para inibir a formação do mineral. Interpretações similares são encontradas no trabalho de Anjos et al. (1995) para solos desenvolvidos de sedimentos coluvionares e aluvionares derivados de rocha arenítica.

O elevado conteúdo de mica na rocha, supostamente ilita, é responsável pela maior CTC nesta porção do perfil, tal como evidenciado nas análises pedológicas de rotina, bem como fornece o mineral, de maneira residual e através dos processos de intemperismo da rocha e formação de saprolito e solo, para os demais horizontes do perfil 
Tabela 7. Conteúdo relativo ${ }^{1}$ dos minerais silicatados e gibbsita na fração argila do solo e glébulas para os perfis P1, P2 e P3.

\begin{tabular}{|c|c|c|c|c|}
\hline \multirow[t]{2}{*}{ Horizonte $^{2}$} & \multirow[t]{2}{*}{ Profundidade } & \multicolumn{3}{|c|}{ Minerais } \\
\hline & & Caulinita & Mica & Gibbsita \\
\hline \multicolumn{5}{|l|}{ Perfil P1 } \\
\hline A & $00-10$ & 2 & 1 & 1 \\
\hline$E$ & $10-25$ & 2 & 1 & 1 \\
\hline Fl-S & $25-45$ & 3 & 1 & 1 \\
\hline $\mathrm{F} 1-\mathrm{C}$ & $25-45$ & 2 & 1 & 1 \\
\hline F2-S & $45-55$ & 3 & 1 & 1 \\
\hline $\mathrm{F} 2-\mathrm{C}$ & $45-55$ & 2 & 1 & 0 \\
\hline $\mathrm{Cr}$ & $55-116$ & 3 & 2 & 0 \\
\hline Crgl & $116-140$ & 3 & 2 & 0 \\
\hline Crg2 & $140-180$ & 3 & 2 & 0 \\
\hline \multicolumn{5}{|l|}{ Perfil P2 } \\
\hline A & $00-10$ & 1 & 2 & 1 \\
\hline $\mathrm{E}$ & $10-26$ & 1 & 1 & 1 \\
\hline Bt1 & $26-38$ & 3 & 1 & 1 \\
\hline $\mathrm{Bt} 2$ & $38-60$ & 3 & 1 & 1 \\
\hline F1-S & $60-85$ & 3 & 1 & 1 \\
\hline $\mathrm{F} 1-\mathrm{C}$ & $60-85$ & 1 & 1 & 0 \\
\hline $\mathrm{F} 2$ & $85-110$ & 2 & 2 & 1 \\
\hline $\mathrm{Cr}$ & $110-164$ & 2 & 2 & 0 \\
\hline $\mathrm{R}$ & $164-190$ & 1 & 3 & 0 \\
\hline \multicolumn{5}{|l|}{ Perfil P3 } \\
\hline $\mathrm{A}$ & $00-13$ & 2 & 1 & 1 \\
\hline $\mathrm{EA}$ & $13-24$ & 2 & 1 & 1 \\
\hline $\mathrm{E}$ & $24-74$ & 2 & 1 & 1 \\
\hline Btgl & $74-100$ & 3 & 1 & 1 \\
\hline Btg2 & $100-140$ & 3 & 1 & 1 \\
\hline
\end{tabular}

${ }^{1}$ Conteúdo relativo: 0 - não detectado, 1 - presente, 2 - moderadamente abundante, 3 - abundante

${ }^{2} \mathrm{~F} 1-\mathrm{S}$ e F2-S: matriz interglebular do horizonte ferricrete

${ }^{2} \mathrm{~F} 1-\mathrm{C}$ e F2-C: glébulas do horizonte ferricrete

${ }^{2} \mathrm{~F} 2$ : matriz e glébulas homogeneizada 

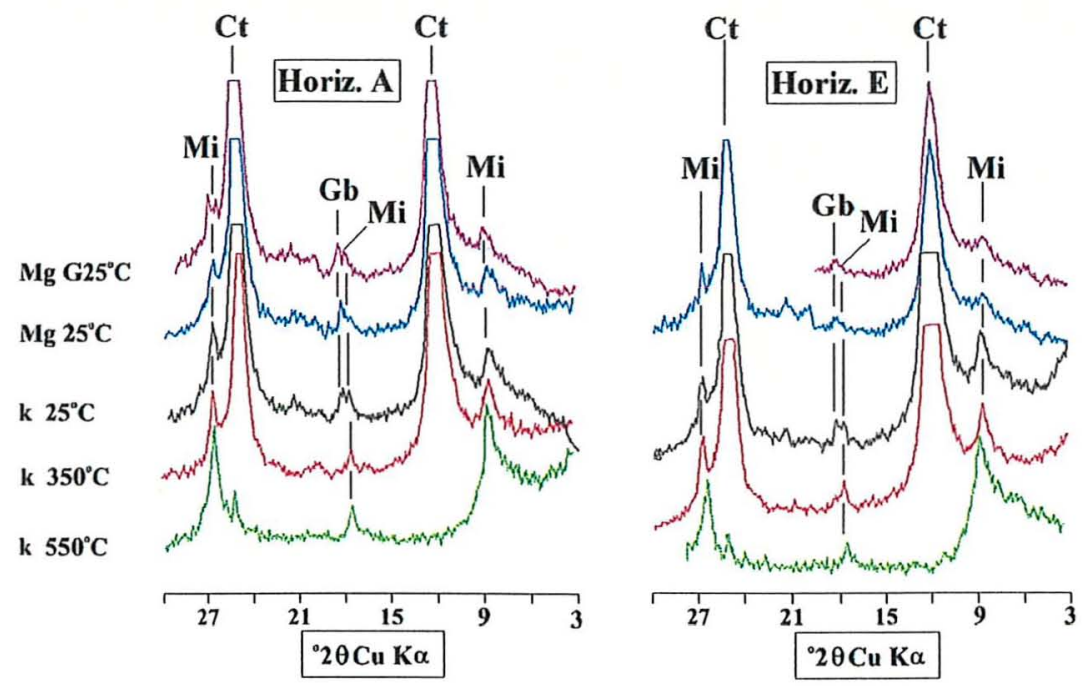

\section{Perfil P1}
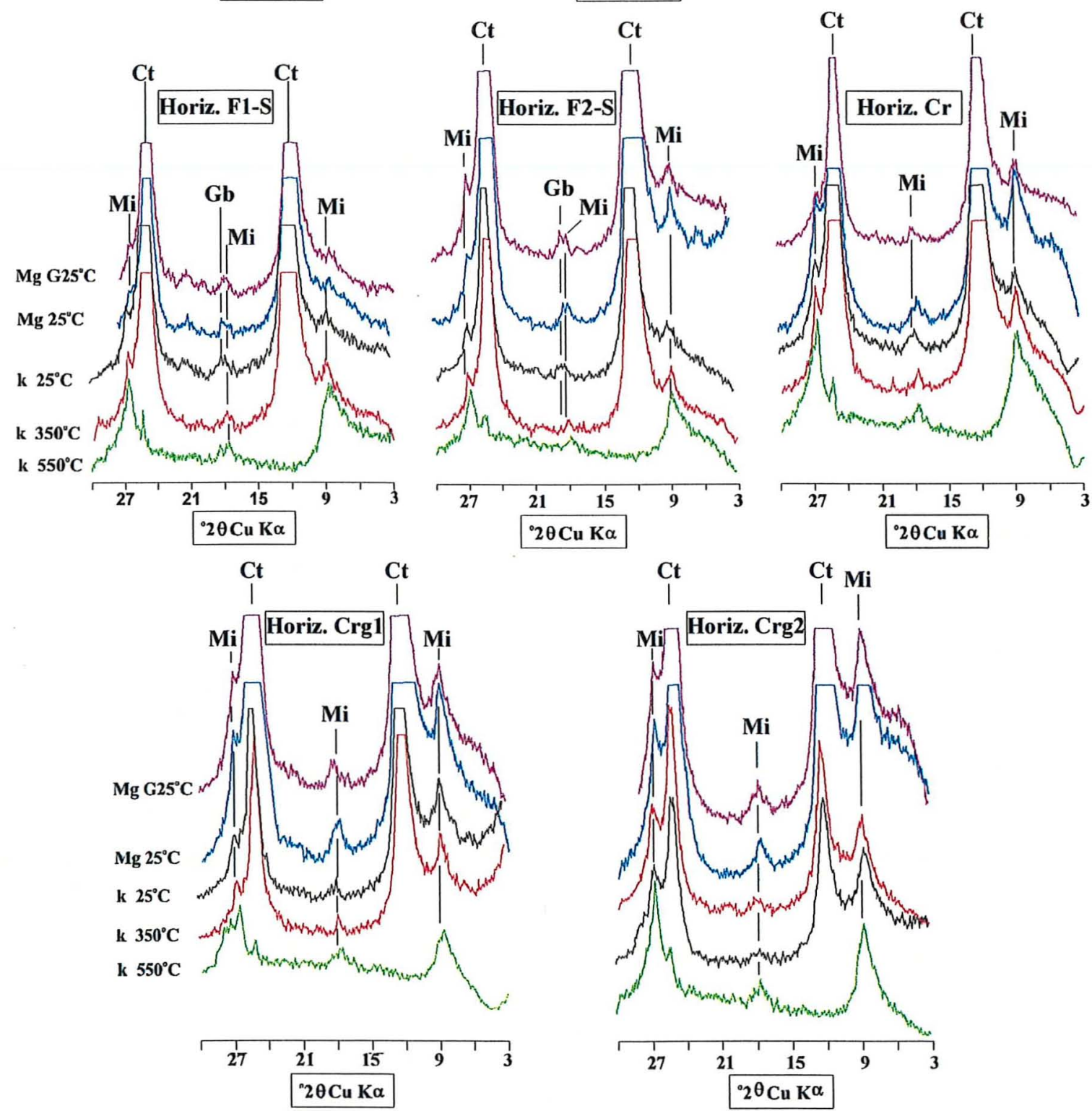

Figura 26: Difratogramas de raio-x da fração argila desferrificada de todos os horizontes e matriz interglebular dos perfis P1, P2 e P3 

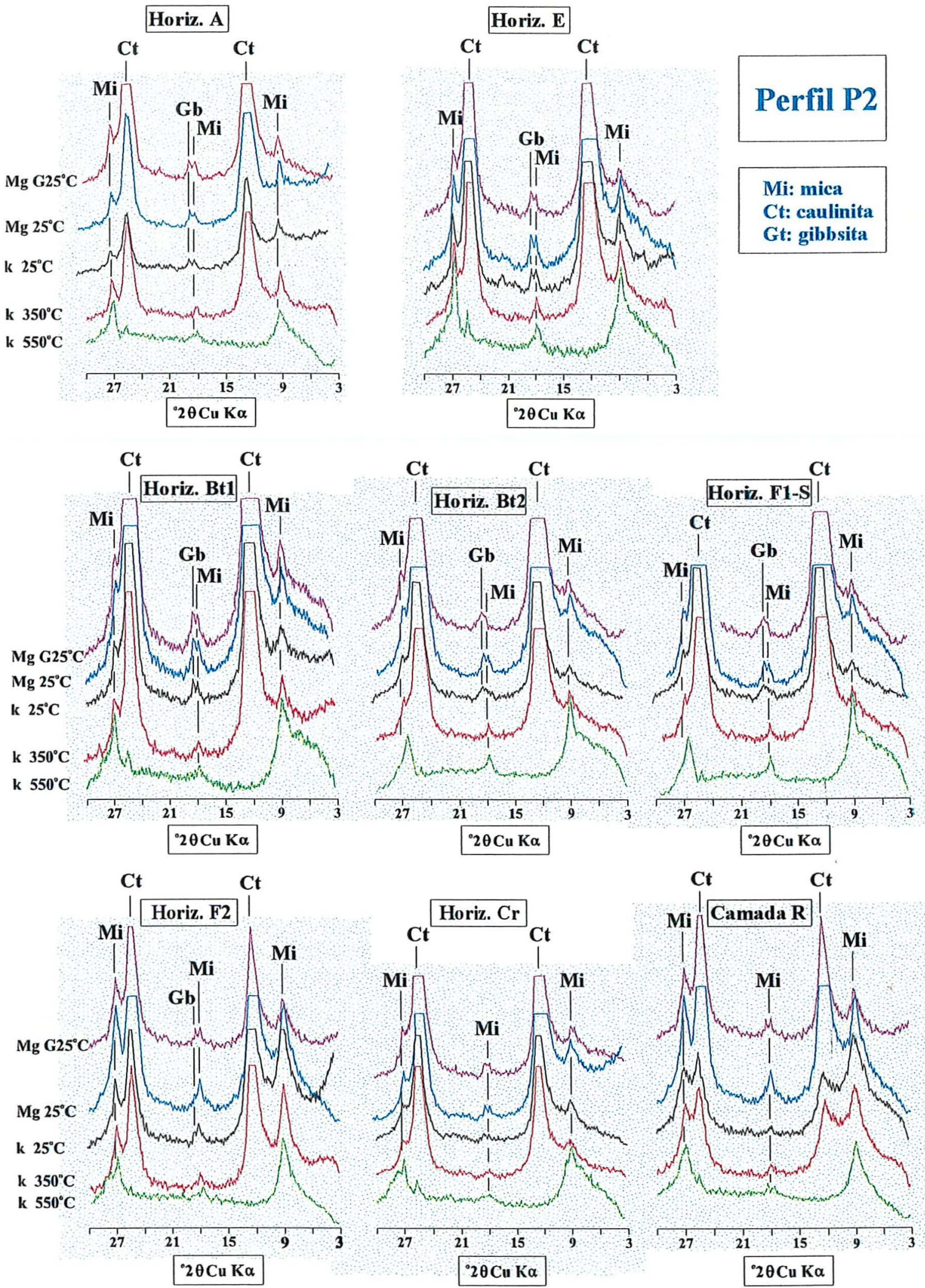

Figura 26. Continuação. 

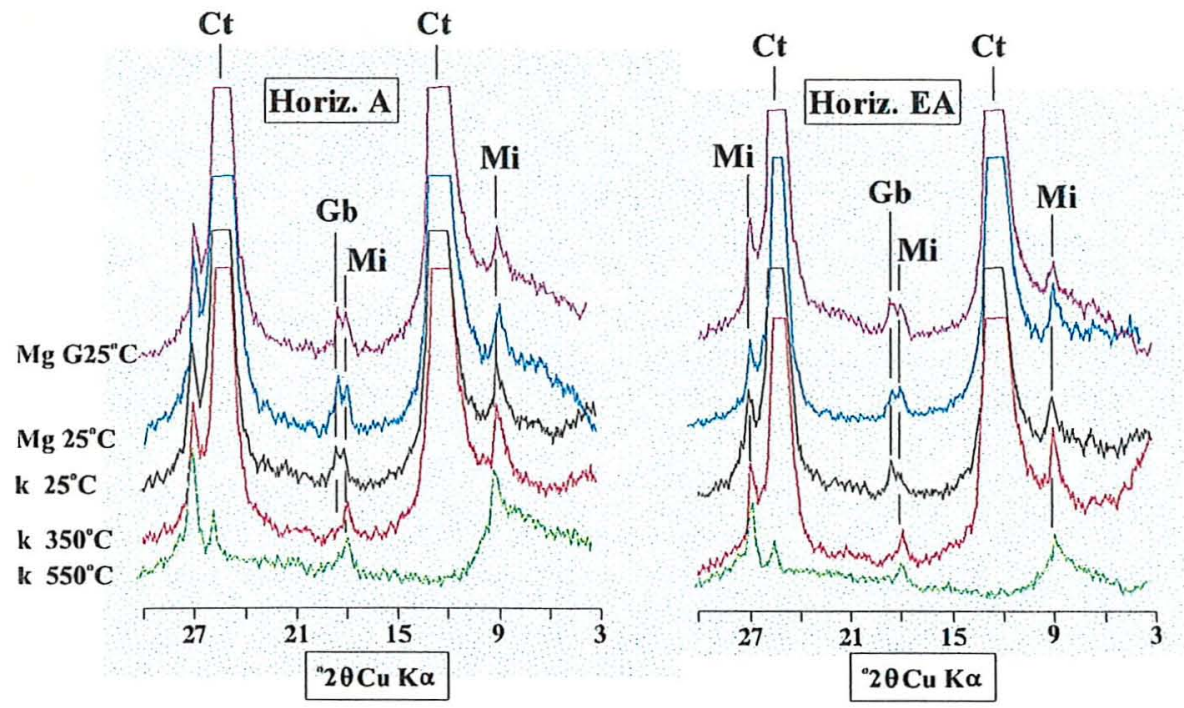

\section{Perfill P3}
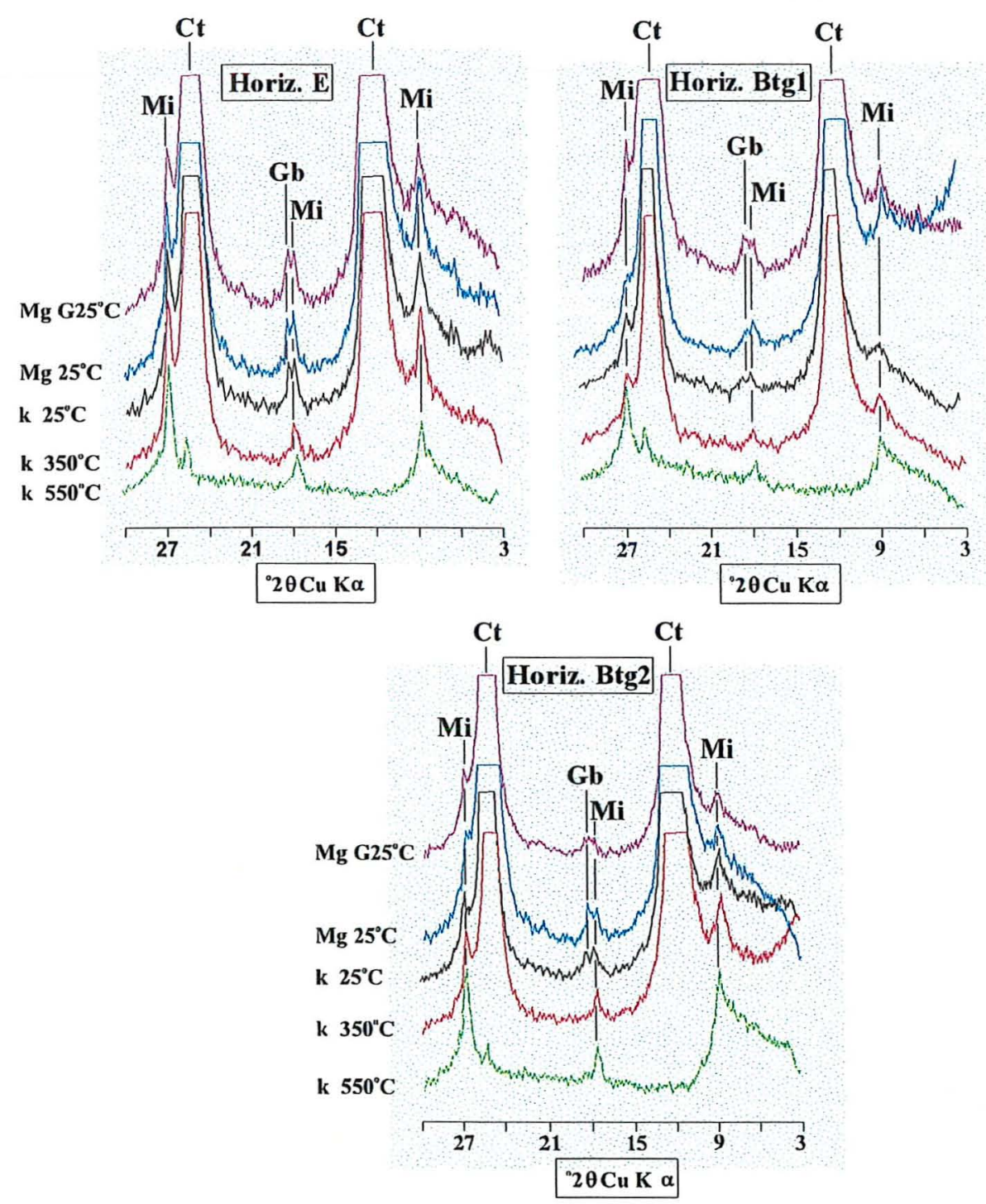

Figura 26. Continuação. 


\subsubsection{Mineralogia dos óxidos de ferro na fração argila}

As amostras foram aquecidas em $\mathrm{NaOH} 5 \mathrm{M}$ durante uma hora a fim de eliminar o efeito da diluição da caulinita e concentrar os óxidos de ferro, seguindo metodologia proposta por Norrish \& Taylor (1961) e modificada por Kämpf \& Schwertmann (1982). Hematita e goetita foram os únicos óxidos de ferro identificados com esse tratamento. No entanto, anatásio $\left(\mathrm{TiO}_{2}\right)$ também foi concentrado e identificado em todos os horizontes estudados (espaçamento $\mathrm{d}=3,52 \AA$ ) (Figura 27). A Tabela 8 revela os conteúdos de hematita $(\mathrm{Hm})$, goetita $(\mathrm{Gt})$, bem como o valor $\mathrm{R}(\mathrm{Hm} / \mathrm{Hm}+\mathrm{Gt})$ e o grau de substituição isomórfica nos óxidos de ferro (SIGt e SIHm). Diferentes métodos foram utilizados no cálculo da substituição isomórfica em $\mathrm{Al}$, pois, além da possibilidade de comparação, também favorecem uma maior segurança nos resultados, uma vez que todos apresentam diferentes fontes de erro. A estimativa por difração de raio-x está sujeita a erros devido a pouca definição nas linhas de difração da goetita e hematita que tem sido utilizadas para os cálculos, entre outros fatores (Barral Silva, 1987), enquanto os métodos químicos apresentam problemas de seletividade do extrator DC (extrai Al de outras fontes que não da estrutura dos óxidos; Fitzpatrick \& Schwertmann, 1982 e Schwertmann \& Lathan, 1986), bem como uma grande variação nos resultados quando as amostras constituem-se de uma mistura de hematita e goetita (Shadfan et al., 1985). Assim, os valores de substituição isomórfica, embora variem consideravelmente entre os diferentes métodos (Tabela 8), possibilitam uma avaliação mais segura de suas tendências. No entanto, ênfase será dada aos resultados de difratometria de raio-x devido a maior coerência dos resultados.

Inúmeros trabalhos tem tratado da substituição isomórfica nos óxidos de ferro dos perfis ferricretes, evidenciando que goetita e hematita podem incorporar grandes conteúdos de alumínio na sua estrutura (Ambrosi \& Nahon, 1986; Anand \& Gilkes, 1987ab; Bourman, 1993; Bourman et al., 1987; Debaveye et al., 1987; Ibanga et al., 1983; Fitzpatrick \& Schwertmann, 1982; Leprun, 1981; Muller \& Bocquier, 1986; Nahon et al., 1977; Schwarz, 1994; Tardy \& Nahon, 1985; Tardy \& Roquin, 1992; Trolard \& Tardy, 1987 e Trolard \& Tardy, 1989). Esses dados, complementados com o 
estudo de outras variáveis, apresentam um grande interesse aos estudos de gênese dos solos e ferricretes, uma vez que podem refletir os ambientes nos quais são formados, bem como serem utilizados como indicadores dos processos pedogenéticos (Fitzpatrick \& Schwertmann, 1982). Neste contexto, os valores de SIGt abaixo de $15 \mathrm{~mol} \%$ nas glébulas petroplinticas (F1-C), determinados pelos diferentes métodos, sugerem e vem a corroborar a origem de lençol aos ferricretes em estudo, tal como afirmam Fitzpatrick \& Schwertmann (1982). Esses autores encontraram uma taxa de substituição na goetita de diferentes ferricretes variando entre 5 a $10 \%$, indicando sua gênese comum e em ambientes hidromórficos. Esses resultados são repetidos aqui, como pode ser observado na Tabela 8 e portanto, sugerem que as glébulas foram formadas sob influência de algum hidromorfismo no passado, embora atualmente ocorram em solos bem drenados. A razão da baixa substituição de $\mathrm{Fe}$ por $\mathrm{Al}$ nos meios hidromórficos também foi explicada pelos autores. Nesses ambientes, o Fe mobiliza-se preferencialmente nas formas reduzidas $\left(\mathrm{Fe}^{2+}\right)$, enquanto o alumínio não tem capacidade de trocar de valência e por isso, sua mobilidade não é afetada pelas variações das condições de redox que se produzem nos meios de hidromorfia parcial. O ferro ferroso move-se até as zonas do solo que apresentam maior aeração, como por exemplo, os macroporos, onde se produziria sua precipitação e formação das glébulas, sem que existisse nenhuma ou apenas poucas fontes de alumínio na sua proximidade. Também, a reação ligeiramente alcalina dos solos hidromórficos faz com que o elemento não esteja disponível para incorporação nos óxidos de ferro.

Examinando-se a Tabela 8, observa-se que os valores de SIGt no solum, saprolito e matriz interglebular determinada por DRX, limitaram-se entre 5 e $30 \mathrm{~mol} \%$, enquanto os valores de SIHm variaram entre 0 a 13 . Esses resultados estão condizentes com os encontrados na literatura, os quais consideram que o conteúdo de Al na goetita varia entre 0 e $33 \mathrm{~mol} \%$, enquanto na hematita são verificadas menores substituições devido às suas condições estruturais, variando entre 0 a $15 \mathrm{~mol} \%$ (Fitzpatrick \& Schwertmann, 1982; Norrish \& Taylor, 1961; Schwertmann \& Taylor, 1989; Tardy \& Nahon, 1985; Trolard \& Tardy, 1987 e Trolard \& Tardy, 1989). Portanto, as substituições isomórficas 
aqui determinadas são altamente variáveis nos perfis e refletem as condições particulares dos horizontes durante a gênese dos óxidos. Resultados similares foram encontrados por Tardy \& Nahon (1985) sob condições naturais. Nota-se que os niveis de substituição em $\mathrm{Al}$ na goetita da matriz interglebular F2-S do perfil P1 e F1-S do perfil P2 são maiores que nas glébulas para as diferentes metodologias utilizadas, bem como, os horizontes texturais do perfil P2 mostram os maiores conteúdos de goetita aluminosa. Esses resultados indicam uma ampla disponibilidade de alumínio no ambiente durante a formação dos óxidos de ferro, pois também hematita encontra-se mais aluminosa na matriz F1-S do perfil P2 e nos horizontes texturais $\mathrm{Bt1}$ e $\mathrm{Bt} 2$. O maior valor de SIGt no horizonte Bt1 (perfil P2) correspondem ao maior valor de SIHm, também sugerindo uma formação simultânea dos óxidos (Gt e Hm) neste horizonte. Também, a camada $\mathrm{R}$ do perfil P2 apresenta um elevado conteúdo de SIGt, no entanto, hematita é relativamente pouco aluminosa, sugerindo uma formação contemporânea da goetita devido a elevada liberação do $\mathrm{Al}$ provindo da desestruturação da caulinita através do mecanismo de ferrólise. Os maiores teores trocáveis do elemento nesta camada corroboram esses resultados. No caso da hematita, os menores valores relativos de substituição isomórfica sugerem uma origem pretérita para uma parte deste mineral na camada $R$, anterior a formação da goetita e em condições pedoambientais de menor disponibilidade de Al. Essa mesma interpretação também pode ser sugerida para os horizontes saprolíticos do perfil P1 e possibilitam uma explicação parcial dos elevados conteúdos de hematita nessas porções inferiores do perfil (elevados valores da relação $R$ ), uma vez que as condições atuais são favoráveis à formação de minerais oxídicos hidratados. A presença de maior umidade, bem como os baixos valores de $\mathrm{pH}$ nesses horizontes e camada, propiciam a formação de goetita secundária (mineral hidratado) em detrimento da hematita (mineral desidratado), conforme sugestões de Kämpf \& Schwertmann (1983). No entanto, esses mesmos autores, citando o trabalho de Nalovic ${ }^{3}$, afirmam que metais pesados, tais como $\mathrm{Mn}$ e $\mathrm{Cu}$, podem coprecipitar com de ferridrita, precursor natural da hematita, retardando sua transformação para goetita e hematita, em favor da formação isolada de hematita. Portanto, o elevado conteúdo de $\mathrm{Mn}$ na rocha do P2 também pode ser parcialmente

\footnotetext{
${ }^{3}$ NALOVIC, L. 1974 Recherches géochimiques sur les éléments de transition dans les sols; Etude expérimentale de l'influence des éléments traces sur le comportmente du fer et l'évolution des composés ferriféres au cours de la pédogénése. Thése Doctorat, ORSTON, Paris.
} 
responsabilizado pelo elevado valor da relação $\mathrm{R}$ nesta porção do perfil, principalmente quando consideramos a forma pouco cristalina desse elemento, tal como evidenciado nos dados de dissoluções seletivas.

Dos resultados e discussões enunciados acima para os perfis $\mathrm{P} 1$ e $\mathrm{P} 2$, propomos aqui que parte da hematita é formada sob condições de maiores potenciais de oxidação nos saprolitos e rocha do $\mathrm{P} 2$, quando o nível do lençol freático estava mais baixo que o atual , possibilitando a desidratação da ferridrita para formas cristalinas de hematita (Kämpf \& Schwertmann, 1983). Essas condições foram posteriores a gênese dos ferricretes. No entanto, as mobilizações atuais de ferro, principalmente proveniente da degradação das glébulas, são responsáveis principalmente pela formação de goetita aluminosa nas porções inferiores dos perfis, tanto favorecida pela maior umidade, como pela presença e maior disponibilidade de Al trocável. Também, essas mobilizações possibilitam a formação atual de alguma hematita aluminosa nos horizontes e camada com elevados conteúdos de $\mathrm{Mn}$, bem como nos poros dos saprolitos e rocha onde a atividade da água é baixa (Tardy \& Nahon, 1985).

O conteúdo dos óxidos ferro na fração argila mostram que as glébulas petroplinticas do perfil P2 são mais ricas nesses minerais oxídicos em relação das demais glébulas e horizontes. No entanto, observa-se que os óxidos ocupam apenas uma pequena parcela da fração argila desses solos e glébulas, sugerindo que grande parte desta fração é dominada por caulinita. Anatásio, ilita e pouca gibbsita complementam a mineralogia das argilas dos materiais estudados.

Analisando-se a relação $R$, nota-se menores valores relativos para as matrizes interglebulares dos perfis ferricretes (em torno de $20 \%$ ). Isso sugere, como já afirmado anteriormente, uma maior umidade neste horizonte, favorecendo a formação de goetita. A maior porcentagem de argila e óxidos de ferro como matrizes de materiais cascalhentos (glébulas) de diferentes diâmetros, bem como a descontinuidade dos poros na transição entre o horizonte ferricrete e o solum acima, possibilitam a permanência da água neste horizonte, uma vez que sua retenção é maior e a perda por evaporação reduzida. Essa hidratação promove a desestabilização da associação entre a caulinita remanescente nas 
glébulas e a hematita, estáveis em meio pouco hidratado e oxigenado (Beauvais \& Tardy, 1991), estabelecendo condições adequadas à degradação das glébulas, bem como à mobilização dos elementos liberados, principalmente $\mathrm{Fe}^{2+}$, aos horizontes saprolíticos e rocha abaixo. Esses mecanismos foram extensivamente debatidos e evidenciados nos capítulos anteriores.

$O$ efeito da umidade na gênese de goetita pode ser verificada no perfil $P 3$, onde os valores de $\mathrm{R}$ reduzem acentuadamente em profundidade, em relação inversa às condições de hidromorfismo. Nota-se também, pela análise dos valores de $\mathrm{R}$, que as glébulas petroplínticas são predominantemente hematíticas, embora elevados conteúdos de goetita estejam presentes. Para as glébulas plínticas predomina goetita na sua constituição, sendo que hematita também ocorre em proporções consideráveis. Esses resultados evidenciam e corroboram a jovialidade dessas glébulas plínticas, uma vez que a ferruginização é primeiramente goetítica nos estágios iniciais de formação e torna-se progressivamente hematítica durante os processos de oxidação (Beauvais e Colin, 1993). As condições oxidantes são cada vez mais expressivas a medida que a impregnação do ferro aumenta e as glébulas são formadas, favorecendo a precipitação de hematita nos poros de pequeno tamanho, supersaturados em ferro e com baixa atividade da água, conforme indicações de Nahon (1986) e Tardy \& Nahon (1985). Assim, a medida que as glébulas evoluem, os poros são progressivamente preenchidos com ferro e caulinita é dissolvida. Uma vez que a acumulação do $\mathrm{Fe}$ como hematita leva a dissolução da caulinita, os constituintes $\mathrm{Al}$ e Si liberados e solúveis são reprecipitados no interior dessas glébulas incipientes, permitindo a formação de uma nova geração do mineral e preenchimento da porosidade remanescente, reduzindo-a progressivamente em tamanho e favorecendo cada vez mais a oxidação da hematita nos pequenos poros. Esse mecanismo ocorre sucessivamente até a completa formação e estabilização de glébulas predominantemente hematíticas e endurecidas.

O processo enunciado acima foi sugerido por Nahon (1991) como etapas sucessivas e retroalimentadas na gênese dos ferricretes, através de um mecanismo geoquímico entitulado "auto-organização", e evidenciam o estágio evolutivo incipiente 
das glébulas plinticas, uma vez que são predominantemente goetíticas e macias. Também, podemos considerar que os elevados conteúdos de goetita nas glébulas petroplínticas são parcialmente conseqüências de sua degradação, uma vez que nesse último processo, o mineral se desenvolve como um córtex ou uma trama marrom e amarela ao redor ou dentro dos nódulos hematíticos, tal como sugerido por vários autores (Ambrosi \& Nahon, 1986; Anand \& Gilkes, 1987b; Beauvais \& Colin, 1993; Beauvais \& Tardy, 1993; Nahon, 1976; Nahon, 1991 e Roquin, 1990) e verificado nas glébulas em estudo. Porém, parte da goetita possivelmente foi herdada durante a gênese desses materiais ferruginosos endurecidos, inicialmente precipitada nos poros de grande tamanho. 


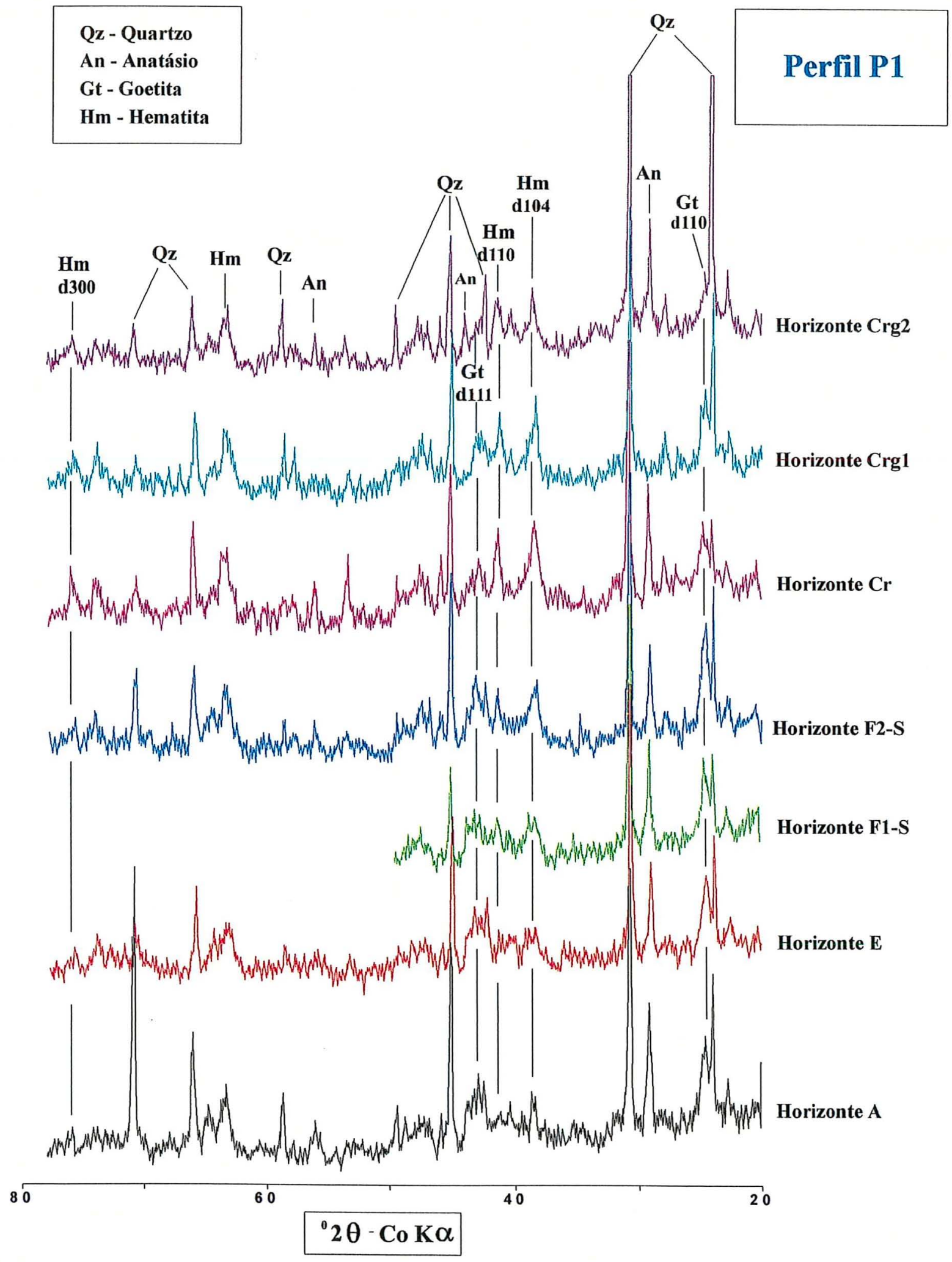

Figura 27. Difratogramas dos óxidos de ferro na fração argila para todos os horizontes, matriz interglegular, camada $\mathrm{R}$ e glébulas dos perfis estudados 


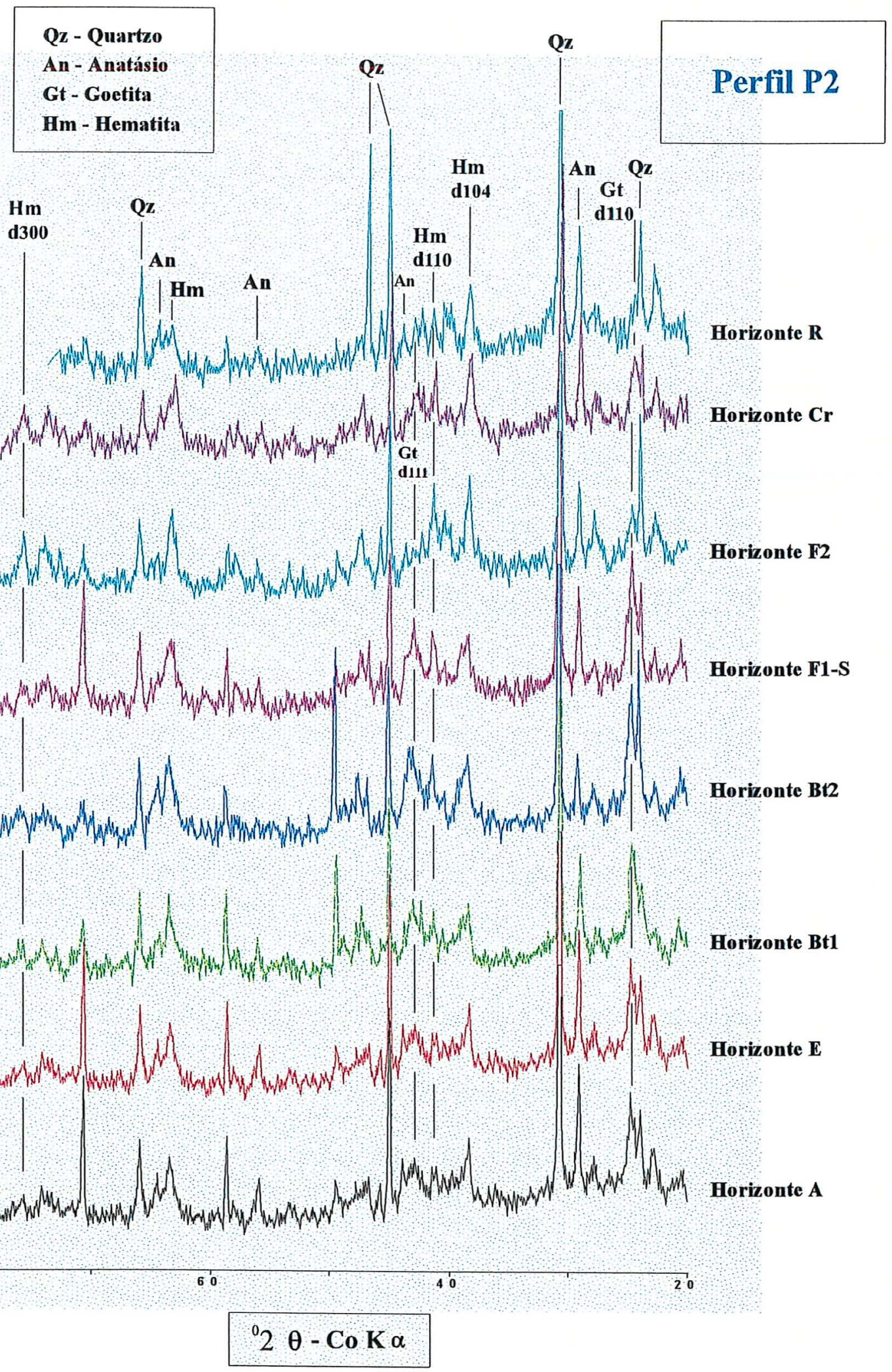

Figura 27. Continuação. 

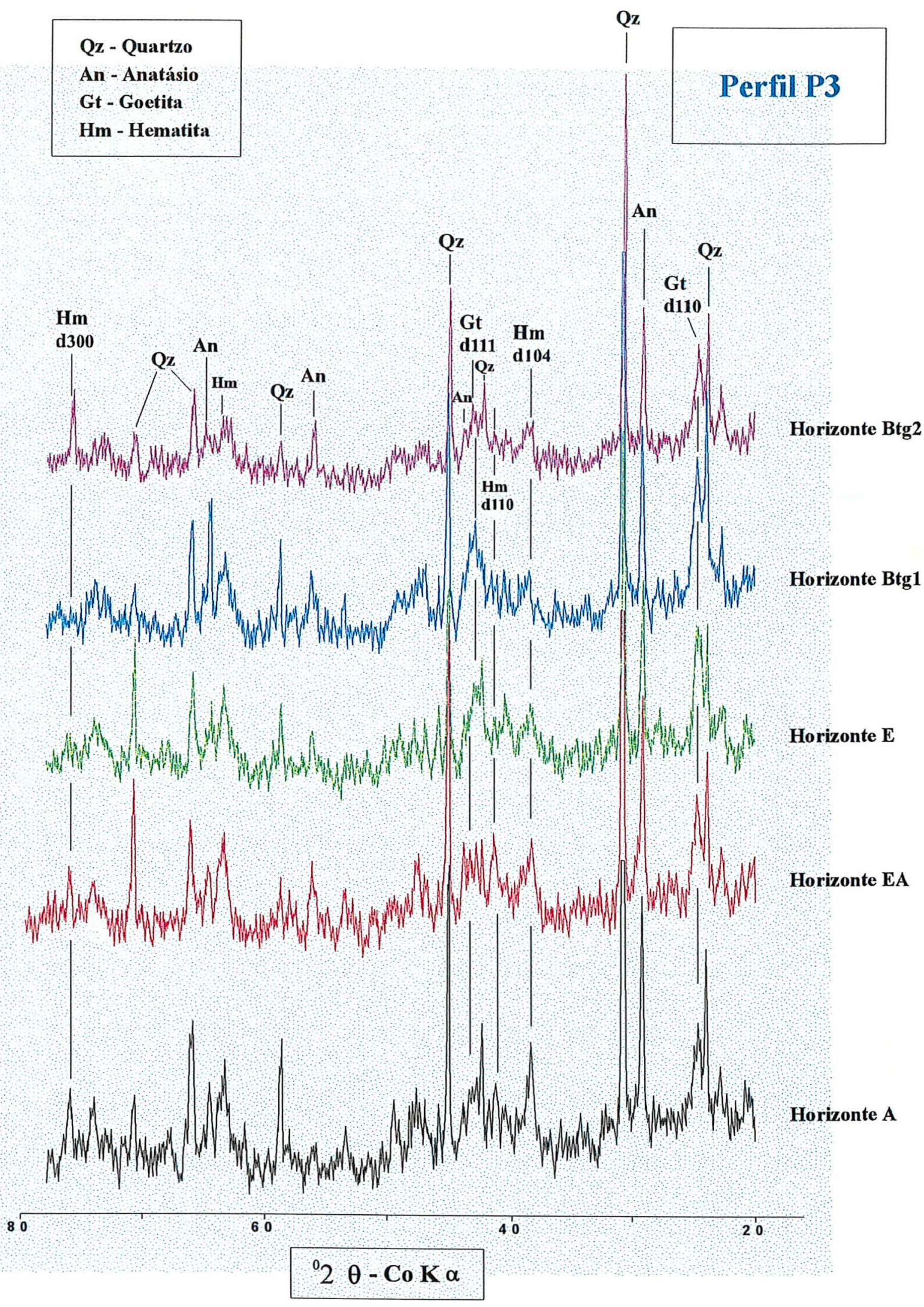

Figura 27. Continuação. 


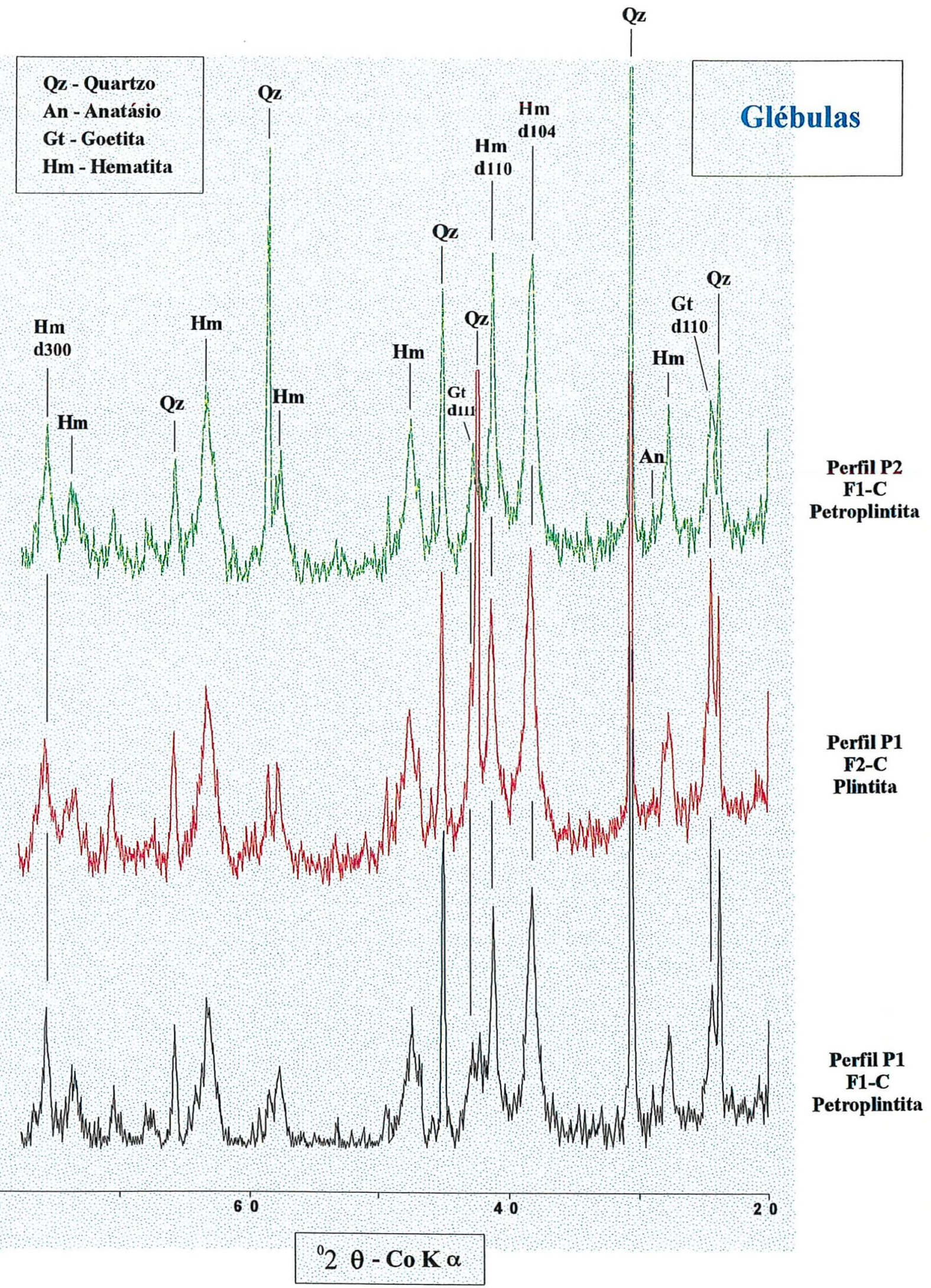

Figura 27. Continuação 
Tabela 8. Valores de Hematita $(\mathrm{Hm})$, Goetita $(\mathrm{Gt}), \mathrm{R}(\mathrm{Hm} / \mathrm{Hm}+\mathrm{Gt})$ e de substituição isomórfica em alumínio na $\mathrm{Hm}$ (SIHm) e Gt (SIGt) determinada por diferentes procedimentos.

\begin{tabular}{|c|c|c|c|c|c|c|c|c|}
\hline \multirow[t]{2}{*}{ Horiz. } & Profund. & $\mathbf{H m}$ & Gt & $\mathbf{R}$ & $\begin{array}{c}\text { SIGt } \\
\text { DRX }^{1}\end{array}$ & $\begin{array}{l}\text { SIHm } \\
\text { DRX }^{2}\end{array}$ & $\begin{array}{c}\text { SIGt } \\
\text { química }^{3}\end{array}$ & $\begin{array}{c}\text { SIOx } \\
\text { química }^{4}\end{array}$ \\
\hline & $\mathrm{cm}$ & $-\cdots---\mathrm{g} / \mathrm{l}$ & Kg------ & $--\%$ & \multicolumn{4}{|c|}{ - } \\
\hline \multicolumn{9}{|l|}{ Perfil P1 } \\
\hline A & $00-10$ & 2.4 & 6,9 & 26 & 14 & 10 & 25 & 14 \\
\hline E & $10-25$ & 1,3 & 12,5 & 10 & 19 & 7 & 26 & 15 \\
\hline F1-S & $25-45$ & 15,9 & 56,0 & 22 & 8 & 7 & 10 & 5 \\
\hline $\mathrm{F} 1-\mathrm{C}$ & $25-45$ & 195,9 & 148,4 & 57 & 10 & 5 & 5 & 3 \\
\hline F2-S & $45-55$ & 14,6 & 57,6 & 20 & 23 & 4 & 16 & 9 \\
\hline $\mathrm{F} 2-\mathrm{C}$ & $45-55$ & 106,2 & 131.4 & 45 & 12 & 2 & 8 & 4 \\
\hline $\mathrm{Cr}$ & $55-116$ & 23,8 & 35.5 & 40 & 18 & 6 & 11 & 6 \\
\hline Crgl & $116-140$ & 16,0 & 22.7 & 41 & nd $^{5}$ & 7 & 14 & 7 \\
\hline $\mathrm{Crg} 2$ & $140-180$ & 7,0 & 9,0 & 44 & 11 & 7 & 2 & 1 \\
\hline \multicolumn{9}{|l|}{ Perfil P2 } \\
\hline $\mathrm{A}$ & $00-10$ & 1,7 & 9,6 & 15 & 15 & 7 & 14 & 7 \\
\hline $\mathrm{E}$ & $10-26$ & 2,9 & 11,0 & 21 & 12 & 3 & 14 & 7 \\
\hline Btl & $26-38$ & 5,4 & 22,9 & 19 & 30 & 13 & 20 & 11 \\
\hline $\mathrm{Bt} 2$ & $38-60$ & 13,3 & 37,8 & 26 & 22 & 8 & 15 & 8 \\
\hline F1-S & $60-85$ & 12,7 & 45,9 & 22 & 19 & 10 & 10 & 5 \\
\hline F1-C & $60-85$ & 272,5 & 139,3 & 66 & 8 & 3 & 5 & 3 \\
\hline F2 & $85-110$ & 72,2 & 64,8 & 53 & 12 & 3 & 4 & 2 \\
\hline $\mathrm{Cr}$ & $110-164$ & 22,8 & 41,4 & 35 & 6 & 1 & 1 & 1 \\
\hline $\mathrm{R}$ & $164-190$ & 49.0 & 14,9 & 77 & 25 & 5 & 12 & 5 \\
\hline \multicolumn{9}{|l|}{ Perfil P3 } \\
\hline A & $00-13$ & 4.5 & 5.4 & 45 & 5 & 0 & 4 & 2 \\
\hline EA & $13-24$ & 1.7 & 6,8 & 20 & 6 & 1 & 4 & 2 \\
\hline$E$ & $24-74$ & 1,3 & 10,7 & 11 & 10 & 7 & 8 & 4 \\
\hline Btgl & $74-100$ & nd & nd & 9 & 17 & nd & 10 & 5 \\
\hline $\mathrm{Btg} 2$ & $100-140$ & nd & nd & 8 & nd & nd & 8 & 4 \\
\hline
\end{tabular}

${ }^{1}$ SIGt DRX: substituição isomórfica do $\mathrm{Fe}$ por Al na goetita, determinada por difração de raio- $x$

${ }^{2}$ SIHm DRX: substituição isomórfica do $\mathrm{Fe}$ por $\mathrm{Al}$ na hematita, determinada por difração de raio-x

${ }^{3}$ SIGt química: substituição isomórfica na goetita determinada quimicamente segundo a expressão (Guillet \& Jeanroy, 1993):

$\mathrm{Al} \%$ molar $=\frac{\left(\mathrm{Al}_{\mathrm{d}}-\mathrm{Al}_{\mathrm{o}}\right) / 27 \times 100}{\left(\mathrm{Al}_{\mathrm{d}}-\mathrm{Al}_{\mathrm{o}}\right) / 27+(\mathrm{Fed}-\mathrm{Feo}) / 55,8}$

${ }^{4}$ SIOx química: substituição isomórfica nos óxidos de ferro $(\mathrm{Hm}+\mathrm{Gt})$ determinada segundo a expressão (Shadfan et al., 1985): Al \% molar $=\frac{\mathrm{Al}_{\mathrm{d}}-\mathrm{Al}_{\mathrm{o}} \times 100}{\mathrm{Al}_{(\mathrm{d}-\mathrm{o})}+\mathrm{Fe}_{(\mathrm{d}-\mathrm{o})}}$

${ }^{5}$ nd: não determinado devido à pouca definição dos picos 


\subsection{Evidências micromorfológicas}

As questões e hipóteses levantadas e argumentadas nos itens anteriores foram posteriormente investigadas através $\mathrm{da}$ análise micromorfológica de amostras indeformadas e coletadas nos diferentes horizontes de cada perfil. A Figura 28 apresenta as posições de coleta das amostras.

Os resultados dessa análise serão apresentados sob três diferentes formas: quadros-resumo (APÊNDICE 2), síntese para cada perfil e finalmente, as fotomicrografias para ilustrar as principais evidências dos processos pedogenéticos discutidos. As glébulas serão analisadas à parte, possibilitando sua caracterização e evidências dos principais mecanismos envolvidos na sua gênese. 

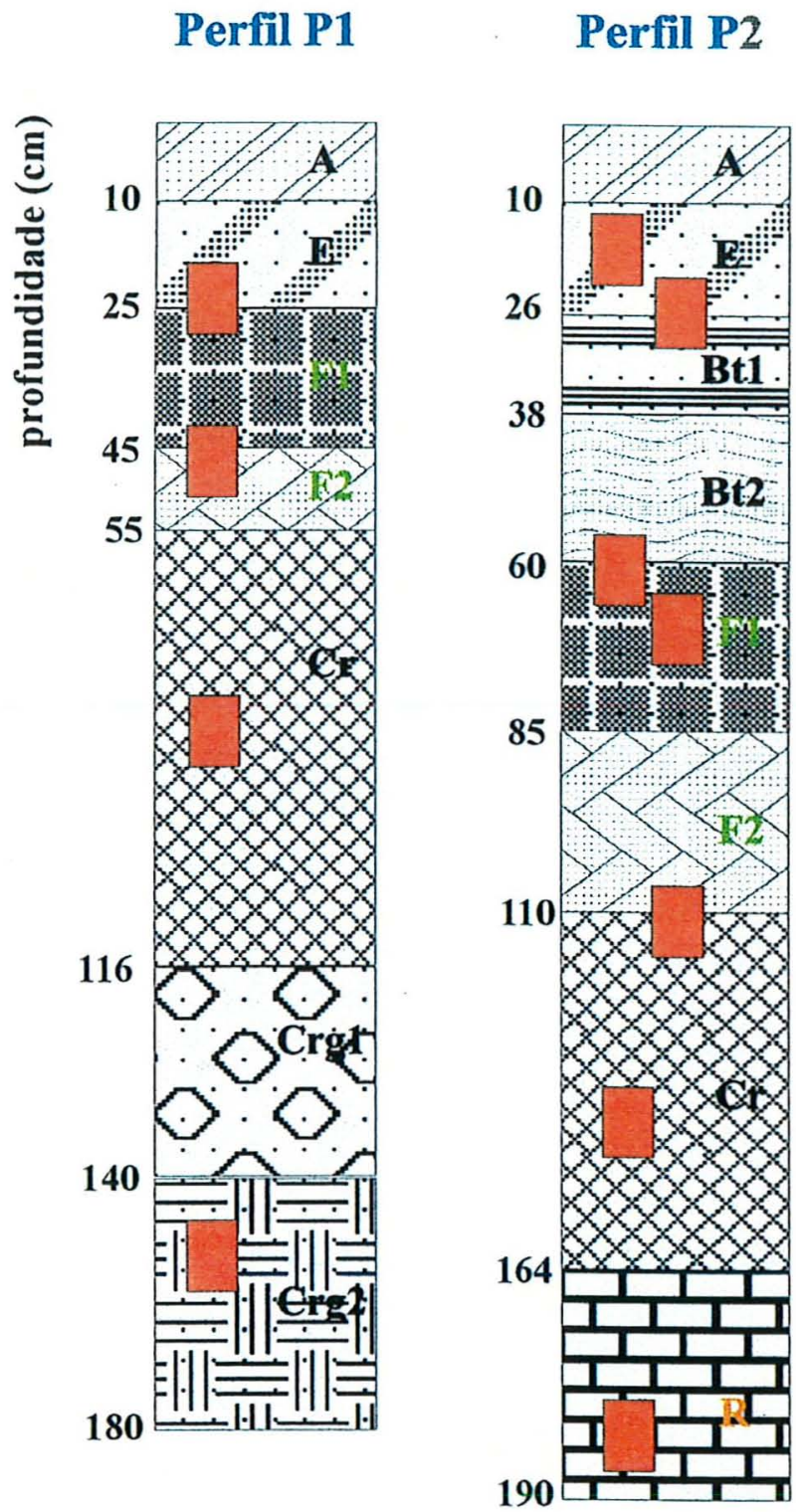

\section{Perfill P3}

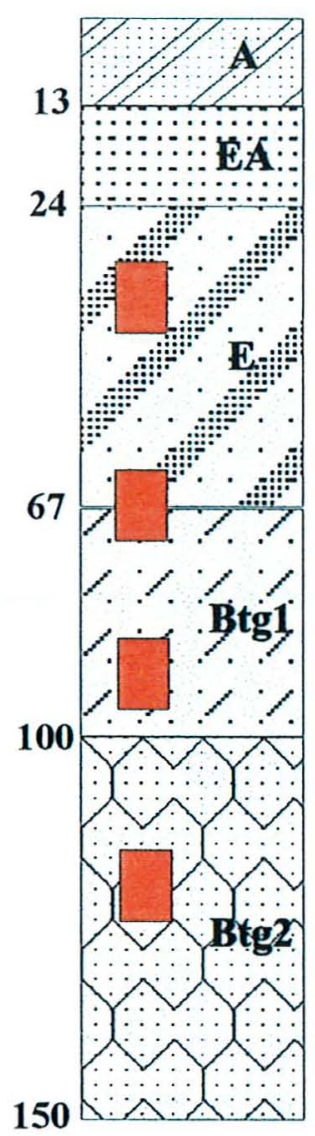

Amostras indeformadas
A, E, $\mathbb{F 1}$... Horizontes dos perfis
$\mathbb{R}$ Rocha

Figura 28. Esquema de disposição dos horizontes e localização de coleta das amostras indeformadas nos perfis. 


\subsubsection{Perfil P1}

A análise deste perfil mostrou, tal como nas observações macromorfológicas, a mobilização do ferro no saprolito e presença constante de diminutas glébulas no solum. As observações feitas nos horizontes saprolíticos evidenciam a presença de uma trama porfirica dominante com tendências gefúrica localmente no horizonte $\mathrm{Crg} 2$, com uma estrutura de base silassépica e fundo matricial constituído de $20 \%$ plasma, $40 \%$ esqueleto e $40 \%$ poros, e que evoluem para uma trama exclusivamente porfirica no $\mathrm{Cr}$ com uma acentuada diminuição da porosidade ( $25 \%$ plasma, $65 \%$ esqueleto e $10 \%$ poros). Além dessas variações, o surgimento de feições pedológicas cutânicas, bem como de um plasma isótico associado a uma estrutura de base silassépica e aumento do esqueleto na dimensão areia muito fina $(\sim 100 \mu \mathrm{m})$, evidenciam e corroboram os mecanismos sugeridos nos itens anteriores para esta porção do perfil. Para ilustrar esses mecanismos, a Figura 29 possibilita uma visão geral do fundo matricial do horizonte $\mathrm{Cr}$ (100 a 110 $\mathrm{cm})$. Observa-se a trama porfirica fechada em que a pequena participação de poros ortocavitários e canais, juntamente com a intensa ocorrência de ferriargilãs de iluviação e hematãs, evidenciam as mobilizações de $\mathrm{Fe}$ e argila no horizonte, possivelmente provindos da matriz interglebular. A maior concentração de $\mathrm{Fe}_{\mathrm{o}}$ na matriz e sua redução em profundidade favorecem essa suposição (Figura 21). Assim, ferro e argila estão preenchendo a porosidade cavitária, reduzindo-a nesta porção do perfil, bem como são responsáveis pelo acentuado acréscimo da fração argila em relação aos demais horizontes inferiores do perfil.

Do enunciado acima podemos inferir que 3 diferentes tipos de plasma podem ser identificados no fundo matricial da Figura 29. O dominante no plano da lâmina constituise de ferro e caulinita e mostra uma coloração vermelho-amarelado (5 YR 4/8) e estrutura de base argilassépica. Corresponde a matriz argilosa predominante dos horizontes saprolíticos. Em tons mais vermelhos, as concentrações plásmicas (cutãs) são predominantemente cinzento escuro $(2,5 \mathrm{YR} 4 / 8)$ e perfazem 20 a $30 \%$ do plasma, enquanto que as segregações de ferro (hematãs) em quantidades similares, são isóticas e de coloração vermelho-escuro acinzentado (10 YR 3/3). A identificação de uma 
cerosidade forte e contínua nos fragmentos saprolíticos durante as observações macromorfológicas confirmam a presença expressiva de cutãs no fundo matricial desta lâmina.

A Figura 30 revela em detalhes os ferriargilãs mostrados e identificados na figura anterior. Observa-se que o ferro está segregado em algumas porções do cutã, isóticos sob nícois cruzados, sugerindo mobilização de $\mathrm{Fe}^{2+}$ posterior a deposição cutânica, difundindo-se e precipitando nos poros de pequeno tamanho na forma de hematita, tal como sugerido por Nahon (1986) e Tardy \& Nahon (1985). Essas segregações aparentemente não mostram qualquer relação de ocorrência, tal como desenvolvimento nas proximidades de microfissuras, bandeamentos que sugerem deposições alternadas de hematãs e ferriargilãs, conforme demonstrado por Castro (1989), de modo que a segregação do ferro no interior dos cutãs supostamente são controladas por mecanismos de difusão e precipitação do ferro ferroso em férrico em microsítios. Nesses, condições adequadas de $\mathrm{pH}, \mathrm{Eh}$, saturação em ferro e atividade da água propiciam sua precipitação na forma de hematita e portanto, a aparente dissimilaridade das ocorrências isóticas da Figura 30 não pode ser justificada pela simples observação em microscópico petrográfico (baixa magnificação).

Observa-se também, pelo exame da Figura 30, a presença de esqueleto quartzoso na fração areia muito fina no interior do ferriargilã. Esse fato sugere a mobilização associada de argila e quartzo muito fino e confirma os apontamentos sugeridos por Nahon (1986) e evidenciados aqui, na discussão dos resultados de distribuição de freqüência do tamanho das partículas. Assim, a maior proporção da fração MF no horizonte $\mathrm{Cr}$ é plenamente justificada pela mobilização conjunta de quartzo fino e argila preenchendo sua porosidade cavitária, uma vez que essas figuras de "argiloquartzoluviação" são freqüentes no plano da lâmina. No entanto, a corrosão, fissuração e deslocamento do quartzo por processos hídricos quando a rocha é reorganizada numa matriz argilosa (Nahon, 1986), também podem ser responsáveis pela redução do tamanho médio do esqueleto nesta porção do perfil, tal como veremos posteriormente. 
$\mathrm{Da}$ análise das Figuras 29 e 30 podemos inferir alguns dos principais mecanismos envolvidos na gênese dos ferricretes em estudo. A morfologia das glébulas plínticas principalmente, mostrando um córtex vermelho-acinzentado, muitas vezes milimétricos, com seu interior contendo muito do saprolito e com matizes mais amarelos, sugerem a participação da iluviação, bem como a segregação e precipitação do ferro nos locais de contato entre os fragmentos de saprolito e o solo já formado. A morfologia de campo possibilitou a identificação de uma matriz friável (solo) entre os fragmentos de saprolito para todos os horizontes abaixo do ferricrete, intensificando a matriz a medida que se aproxima da superficie.

A nivel microscópico, a Figura 29 mostra que os ferriargilãs de iluviação (Figura 30) estão depositados exatamente na porosidade gerada entre os fragmentos de saprolito e o solo, bem como observa-se que há uma maior precipitação do ferro nas bordas do fragmento saprolítico em relação ao seu interior. Certamente, os maiores potenciais de oxidação nessa porosidade de maior tamanho favorecem a precipitação do elemento, estendendo-se a poucos milímetros no interior dos fragmentos saprolíticos e originando algumas das glébulas identificadas na área em estudo. A Figura 31 evidencia esse mecanismo de formação, embora a maioria das glébulas diferem em morfologia como veremos posteriormente. Nota-se que o córtex do nódulo mostra uma maior concentração de plasma em relação ao seu interior, assim como uma maior participação de esqueleto na fração areia muito fina $(\sim 100 \mu \mathrm{m})$ e uma maior cristalinidade e/ou quantidade de hematita. Essa última evidência é identificada através da presença de matrizes mais amarelos no interior do nódulo em relação ao córtex. A morfologia da glébula sugere um mecanismo de iluviação de plasma acompanhado de esqueleto fino $\mathrm{e}$ depositados nos poros entre os fragmentos saprolíticos e o solo, possibilitando a maior precipitação ou cristalinidade do ferro no córtex, tal como evidenciado atualmente, devido aos maiores potenciais de oxidação nessa porosidade. Aportes de $\mathrm{Fe}^{2+}$ e mecanismos de iluviação, tanto no interior dos fragmentos saprolíticos como no solo (matriz), favorecem a segregação e precipitação do ferro, promovendo a formação concomitante do córtex e desenvolvimento das glébulas plínticas, tal como encontra-se 
atualmente nos perfis. Essas são individualizadas e cessam seu processo de crescimento a medida que alguns volumes formam um conjunto compacto de intensa segregação de ferro (saprolito ferruginizado e mais macio que a atual plintita), com menor porosidade no seu interior, possibilitando e favorecendo os fluxos de água no contato entre esse material e sua matriz. Esse fluxo hídrico preferencial promove a dissolução dos minerais e iluviação das argilas, originando uma porosidade entre os volumes de maior segregação de ferro ainda macios e os de menor, possibilitando com isso, a formação e individualização da plintita e de sua matriz friável. Ainda, esse maior fluxo hídrico na matriz favorece uma constante mobilização do ferro ferroso, seja para o mesmo horizonte, seja para outras porções do perfil ou paisagem, desfavorecendo sua precipitação e formação de nódulos e concreções, assim como promovendo a geração de goetita aluminosa, tal como evidenciado anteriormente nessa porção do perfil.

Inicialmente, os sítios preferenciais de segregação são aqueles de maiores potenciais de oxidação, ou seja, de maior porosidade e nas proximidades dos poros maiores onde a menor atividade da água prevalece. No entanto, a medida que a plintita evolui, os poros são progressivamente preenchidos com ferro e caulinita, dissolvida durante a precipitação do primeiro, tornando-os cada vez menores (Nahon, 1991), supersaturados em ferro e com menor atividade de água, favorecendo a formação de hematita em detrimento da goetita (Tardy \& Nahon, 1985). A concentração e precipitação dos óxidos de ferro é acompanhado por ciclos sucessivos de umidecimento e secagem, favorecendo a mobilização e segregação do ferro nos períodos de maior disponibilidade de água. Nessas condições forma-se o material ainda macio, assemelhando-se ao saprolito ferruginizado, e que progressivamente torna-se endurecido nos periodos secos que se sucedem, devido a completa desidratação, oxidação e maior cristalinização dos compostos de ferro no seu interior, tal como encontramos hoje nos horizontes plínticos, obliterando parcialmente a estrutura do saprolito. Assim, estações secas e úmidas bem definidas são favoráveis, se não essenciais, na gênese dos ferricretes (Alexander \& Cady, 1962; Humbert, 1948; McFarlane, 1976; Sivarajasingham et al., 1962 e Thomas, 1994). No entanto, a oscilação do lençol proporcionou condições 
alternantes de umidecimento e secagem que promoveram a concentração do ferro e a formação dos materiais plínticos e petroplínticos, tal como sugerido por McFarlane (1976, p. 43) para "lateritas" de lençol. Essa autora salienta que "a natureza sazonal do clima atmosférico é exagerado ao nivel do solo". Possivelmente, as plintitas foram menos influenciadas pela oscilação do lençol em relação aos materiais petroplinticos, embora seu efeito se fez sentir por todo o perfil.

Como sugerido anteriormente, uma hidromorfia "suspensa" no periodo úmido possibilitou a remoção do $\mathrm{Fe}^{2+}$ da matriz petroplíntica e sua concentração nos horizontes saprolíticos inferiores, que durante a estação seca e com o lençol a maiores profundidades, proporcionou a precipitação e maior cristalinização aos óxidos na formação do material plíntico.

Atualmente as condição são adequadas à formação de plintita nos horizontes saprolíticos $\mathrm{Cr}$ dos perfis ferricretes (P1 e P2). As Figuras 29 e 30 sugerem mecanismos pedogenéticos atuais de saprolitização da rocha (P1) com posterior mobilização, precipitação e segregação de ferro (ferruginização), etapas iniciais na formação de plintita, uma vez que as condições são permanentemente mais oxidantes nessa zona em relação aos horizontes inferiores $(\mathrm{Crg} 1$ e $\mathrm{Crg} 2)$. A significativa redução do espaço poral no $\mathrm{Cr}$ proporciona condições cada vez mais oxidantes à precipitação do ferro na forma de hematita, provindo da degradação da petroplintita, tal como sugerido anteriormente. Essas condições favoráveis e atuais estão relacionadas a manutenção e extensão da hidromorfia "suspensa" nos horizontes petroplinticos e plínticos, bem como ao rebaixamento permanente do lençol freático na paisagem. A hidromorfia "suspensa", intensificada pelo desenvolvimento do horizonte plíntico, favorece a mobilização do $\mathrm{Fe}^{2+}$ e argila para os horizontes inferiores, enquanto o rebaixamento do lençol propiciou condições oxidantes (Eh) adequadas a precipitação e segregação do ferro no $\mathrm{Cr}$.

A diferença entre a porosidade da matriz interglebular e horizonte superficial franco arenoso pode ser observada das Figuras 31 e 32. Nota-se uma trama porfirica fechada de coloração vermelho-amarelada (5 YR 4/6) na matriz interglebular (Figura 31 ), com um pequeno desenvolvimento do espaço poroso (30\% plasma, $50 \%$ esqueleto 
e $20 \%$ poros ). Esse é dominado por ortocavidades irregulares de diâmetro médio de 0,2 $\mathrm{mm}$ e secundariamente por fissuras e canais. No plano da lâmina, algumas porções do fundo matricial interglebular mostram-se compactas, com pequeno desenvolvimento poral, tal como descrito acima, enquanto outras e em menores proporções, são mais porosas, dominando ortocavidades alongadas e canais de dimensões médias de $0,5 \mathrm{~mm}$. Comparativamente ao horizonte E, a Figura 32 evidencia a significativa proporção de poros em relação ao plasma e esqueleto ( $5 \%$ plasma, $50 \%$ esqueleto e $45 \%$ poros). Uma porosidade de empilhamento é dominante, embora cavidades arredondadas e de dimensões superiores a $0,7 \mathrm{~mm}$ ocupam proporções significativas do fundo matricial. Este mostra-se predominantemente constituído de uma trama quitônica $\mathrm{e}$ secundariamente gefúrica, aumentando a proporção da última a medida que se aproxima do horizontes ferricrete. Nódulos irregulares de diâmetro aproximado de $0,4 \mathrm{~mm}$ estão presentes nos últimos $4 \mathrm{~cm}$ do horizonte $\mathrm{E}$ ( $60 \%$ solo e $40 \%$ glébulas), dispersos numa trama predominantemente gefúrica que gradualmente evolui para porfirica na matriz interglebular, juntamente com o aumento relativo do plasma, bem como com aumento da quantidade e dimensão das glébulas ( $80 \%$ glébulas e $20 \%$ matriz).

A transição $\mathrm{F} 2 / \mathrm{Cr}$ é marcada por um acréscimo acentuado da porosidade cavitária ( $20 \%$ plasma, $30 \%$ esqueleto e $50 \%$ poros no plano da lâmina), progredindo em tamanho e quantidade a medida que distancia-se do horizonte plintico. As Figuras 33 e 34 evidenciam esses apontamentos. Nota-se poros cavitários de $0,5 \mathrm{~mm}$ de diâmetro médio na porção inferior do horizonte plíntico (Figura 33), com um fundo matricial porfirico e estruturas plásmicas de colorações vermelhas mais intensas em relação ao fundo matricial, ocupando proporções significativas do plasma. Essas mostram-se com uma birrefringência manchada sob nícois cruzados (silassépica), sugerindo uma origem associada a processos de neoformação dos minerais argilosos, típicos dos horizontes saprolíticos e reconhecidos como cutãs de transformação. Assim, a presença dessas estruturas plásmicas associadas a ferriargilãs de iluviação com orientação forte e contínua (Figuras 29, 30 e 31), são responsáveis pelo aspecto ceroso observado na morfologia de campo e no horizonte $\mathrm{Cr}$. A medida que se distancia do horizonte plíntico, mas ainda 
próximo, a porosidade é maior, como mostra a Figura 34. Nela observa-se ortocavidades $(0,8 \mathrm{~mm}$ de diâmetro) em estágios de desmantelamento, promovendo a coalescência desses poros e degradação dos agregados porfiricos. Nota-se também, o possivel estado de dissolução do esqueleto quartzoso associado aos poros, evidenciando o estado geral de desmonte nessas porções superiores do horizonte $\mathrm{Cr}$, possivelmente condicionadas pelo maior fluxo hidrico. Estruturas similares foram encontradas por Castro (1989) nos horizontes texturais de subsuperficie na região de Marilia. Assim, tal como sugerido anteriormente, a presença de esqueleto na dimensão areia muito fina nesta porção do perfil é promovida tanto pela corrosão do grão de quartzo pela água, como pela iluviação desses elementos associados às argilas. Com a significativa porosidade gerada imediatamente abaixo do horizonte plíntico, associada à disponibilização dos elementos (areia fina, silte e argila) provindos da degradação das glébulas, possibilitam a mobilização do $\mathrm{Fe}^{2+}$ dos horizontes superiores, bem como de argila e frações mais grosseiras, os quais são depositados na base do horizonte $\mathrm{Cr}$ sob condições mais estáveis, reduzindo significativamente sua porosidade e promovendo condições fisico-químicas cada vez mais adequadas a precipitação e segregação do ferro "em massa". A atual oscilação do lençol freático exerce um efeito fundamental nesse processo, principalmente no comportamento do ferro.

O esqueleto é constituído predominantemente por quartzo, embora quantidades aproximadas a $3 \%$ de feldspatos estão presentes no horizonte $\mathrm{Crg} 2$, reduzindo em quantidade e tamanho a medida que se aproximam da superficie. Nos horizontes $\mathrm{A}$ e $\mathrm{E}$ perfazem menos que $1 \%$ do total de grãos de esqueleto e alguns encontram-se fortemente fissurados e ferruginizados. Isso sugere uma origem associada às glébulas, bem como alguma influência da degradação dos ferricretes na gênese do solo acima. Quanto a forma, o esqueleto desses horizontes superficiais mantém as mesmas aparências em relação aos demais horizontes do perfil, apenas variando sua granulometria. As areias grossas e médias são predominantemente subarredondadas e lisas, enquanto as frações fina, muito fina e silte mostram-se subangulares, mantendo o alisamento da superficie. Esse fato vem a corroborar a origem pedogenética in situ para esses horizontes 
superficiais, uma vez que, caso fossem transportados por erosão diferencial, predominariam grãos mais arredondados principalmente nas frações $F$ e MF.

A atividade biológica no perfil foi bastante significativa, sendo evidenciada pela presença de pedotúbulos (isotúbulos) de dimensões variando entre 1 a $6 \mathrm{~mm}$, de formas predominantemente circulares e geralmente com quartzo de menores dimensões no seu interior em relação ao fundo matricial.

Do enunciado acima, podemos sugerir uma origem cíclica e ordenada na gênese dos ferricretes. Inicialmente formou-se a petroplintita a qual está se degradando e liberou ferro para a formação da plintita, que por sua vez pode transformar-se irreversivelmente na primeira através de ciclos sucessivos de umidecimento e secagem (Alexander \& Cady, 1962; Curi et al., 1993; Daniels et al., 1978 e Sivarajasingham et al., 1962). Aparentemente as glébulas plínticas cessaram seu crescimento, uma vez que atualmente as condições fisico-químicas da base dos horizontes $\mathrm{Cr}$ de ambos os perfis ferricretes (P1 e P2) são adequadas a segregação do ferro mobilizado dos horizontes superiores, iniciando-se um novo ciclo na gênese dos ferricretes. No entanto, sugere-se aqui que os horizontes petroplínticos foram formados no estreito limite de oscilação do lençol freático, conforme sugestões de vários autores (Alexandre \& Cady, 1962; Bigarella et al., 1996; Bourman, 1993; Bourman et al. 1987; Goldbery \& Beyth; 1984, King et al., 1990; McFarlane, 1976; McFarlane, 1983; Pedro \& Melfi, 1982 e Wright et al., 1992) e correspondem as etapas finais de segregação do ferro e desenvolvimento dos ferricretes. As variáveis na gênese dos horizontes petroplinticos em relação aos plínticos serão posteriormente elucidados. 


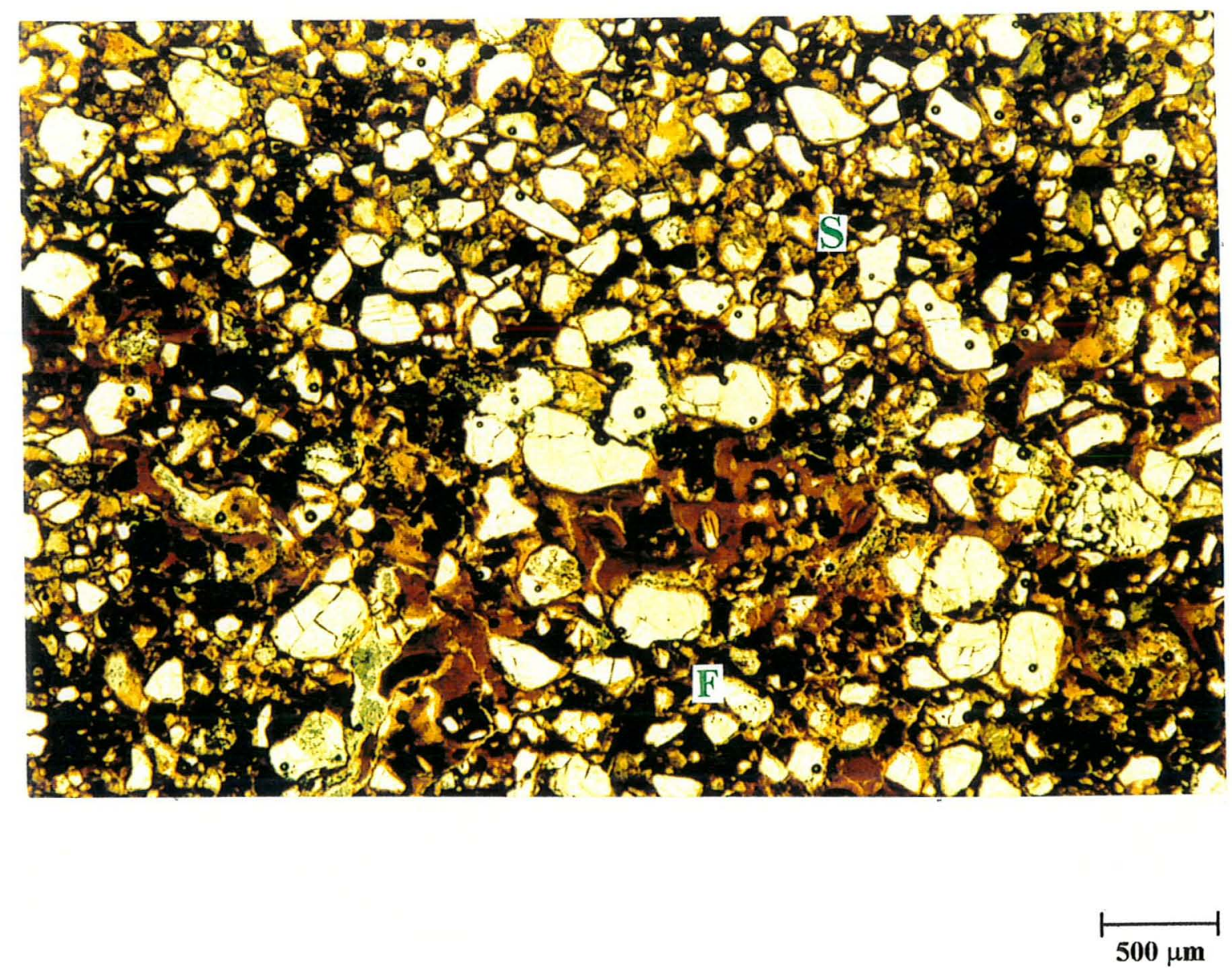

Figura 29. Vista geral do horizonte $\operatorname{Cr}(100$ a $110 \mathrm{~cm})$ do perfil P1; nota-se a deposição dos ferriargilãs na porosidade gerada entre os fragmentos de saprolito (F) e o solo (S), bem como a intensa ferruginização (ferrãs isóticos) concentrada principalmente na proximidade dos poros (LN - 2,5x). 
A
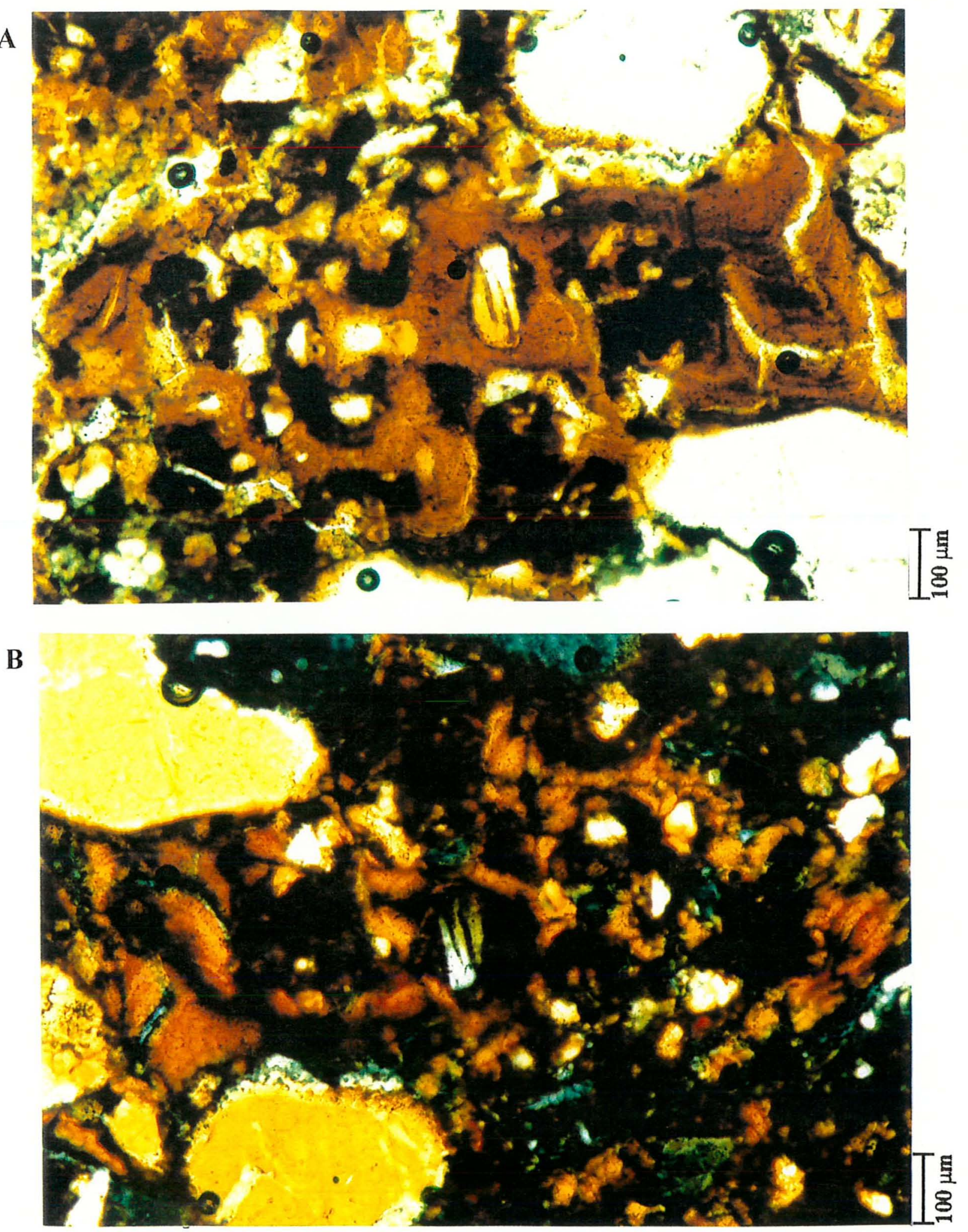

Figura 30. Detalhes dos ferriargilãs da figura anterior. Nota-se a presença de esqueleto na fração areia muito fina, sugerindo iluviação conjunta de argila e quartzo. A acumulação de ferro por difusão nessas estruturas são responsáveis pelas porções isóticas que apagam a orientação forte e contínua, características dos ferriargilãs de iluviação (A - LN 10x; B - LP; 10x). 


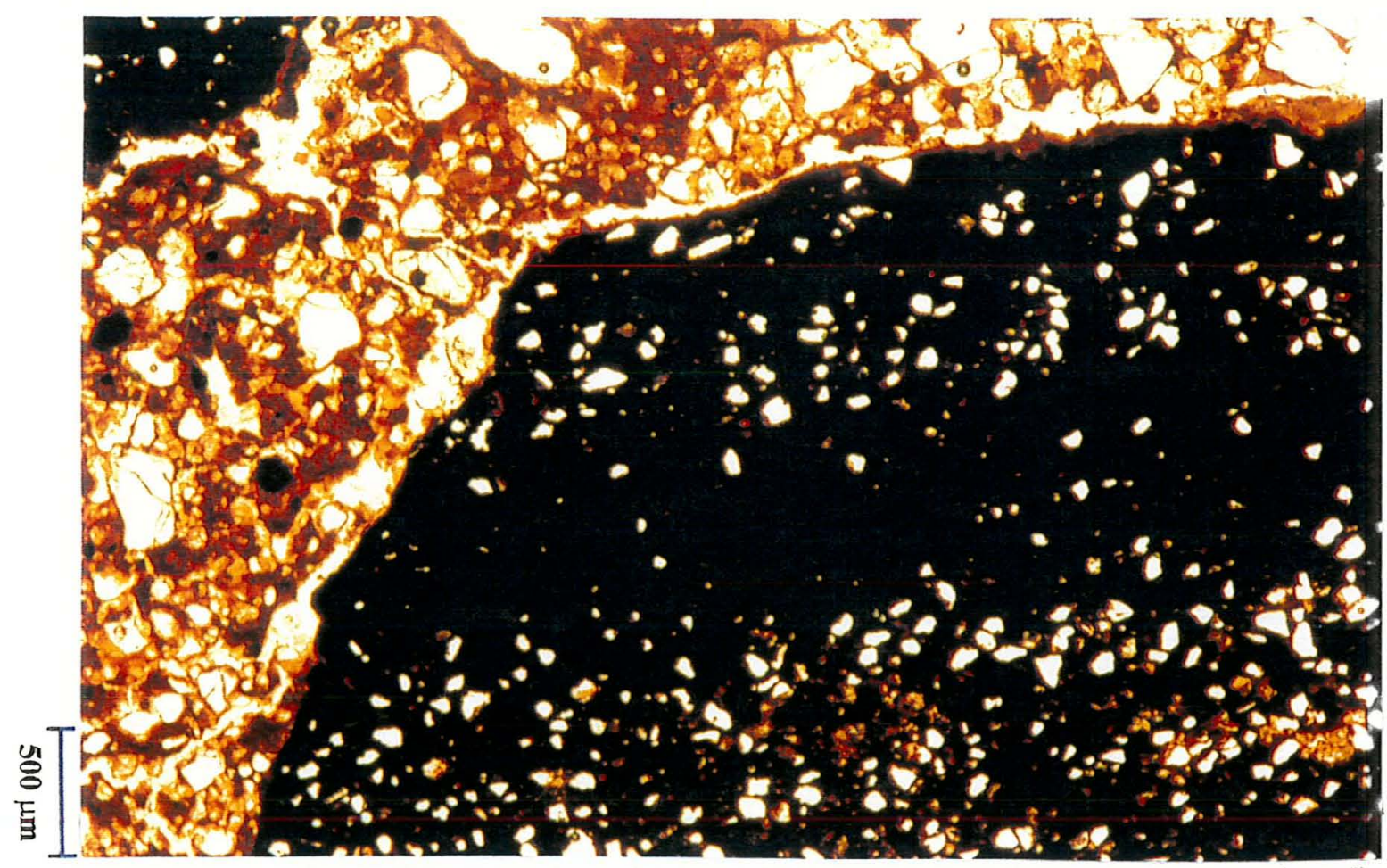

Figura 31. Fotomicrografia mostrando o córtex com maior concentração de plasma e esqueletos finos. Nota-se a presença de plasma com matizes mais amarelos no interior das glébulas, sugerindo menores conteúdos de hematita. A matriz interglebular é porfírica com pequena porosidade cavitária (LN 2,5x).

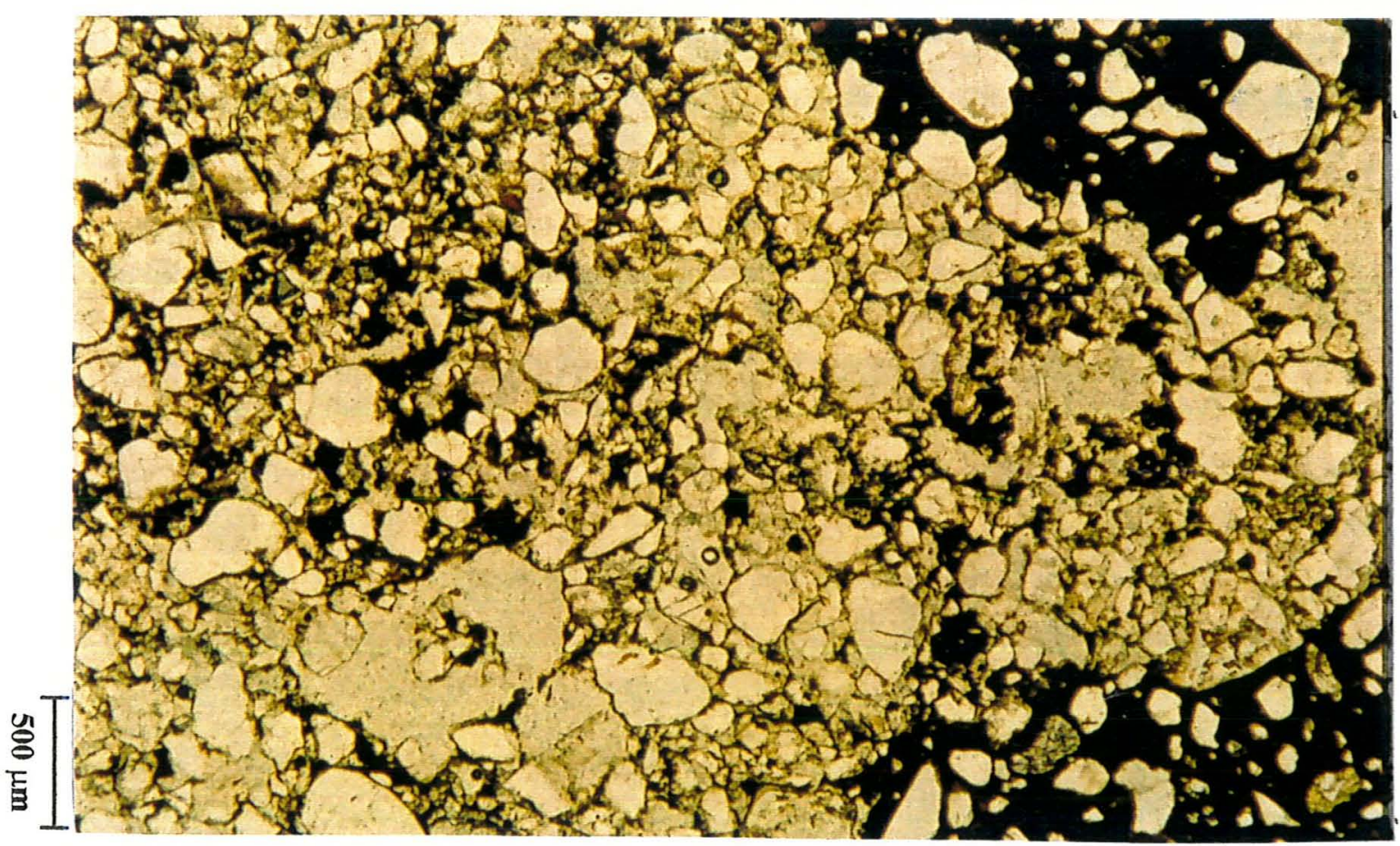

Figura 32. Visão geral do horizonte $\mathrm{E}$ nas transição do ferricrete. Nota-se a presença expressiva da porosidade de empilhamento e cavitária, bem como o desenvolvimento da trama gefúrica. $\mathrm{O}$ esqueleto mostra-se subarredondado para as frações mais grosseiras e subangulares para finas. (LN 2,5x). 


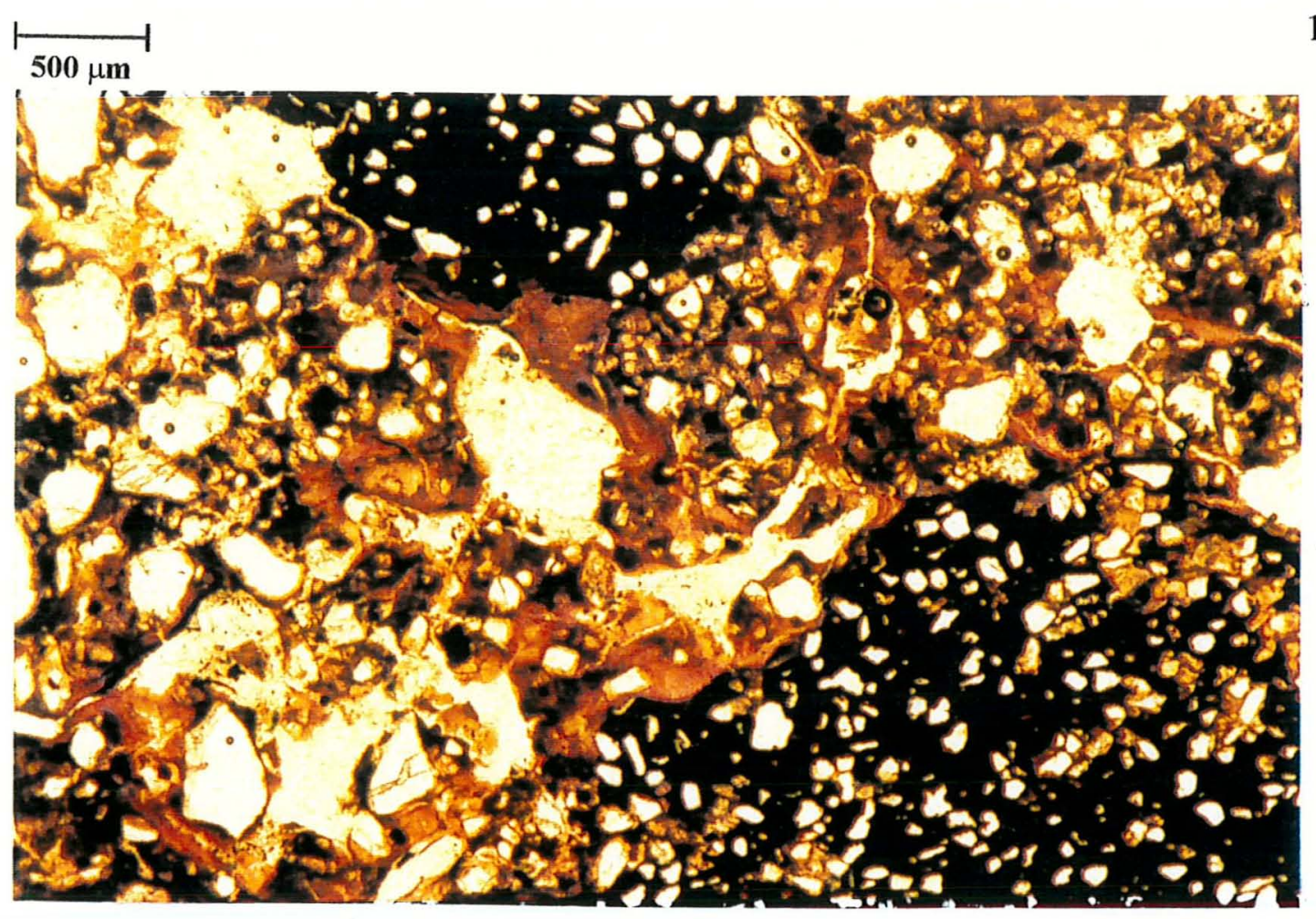

Figura 33. Fotomicrografia da transição $\mathrm{F} 2 / \mathrm{Cr}$ do perfil $\mathrm{P} 1$. Nota-se a presença de uma porosidade metacavitária $(\mathrm{C})$ com cutãs de transformação na sua parede ( $\mathrm{LN}-2,5 \mathrm{x})$.

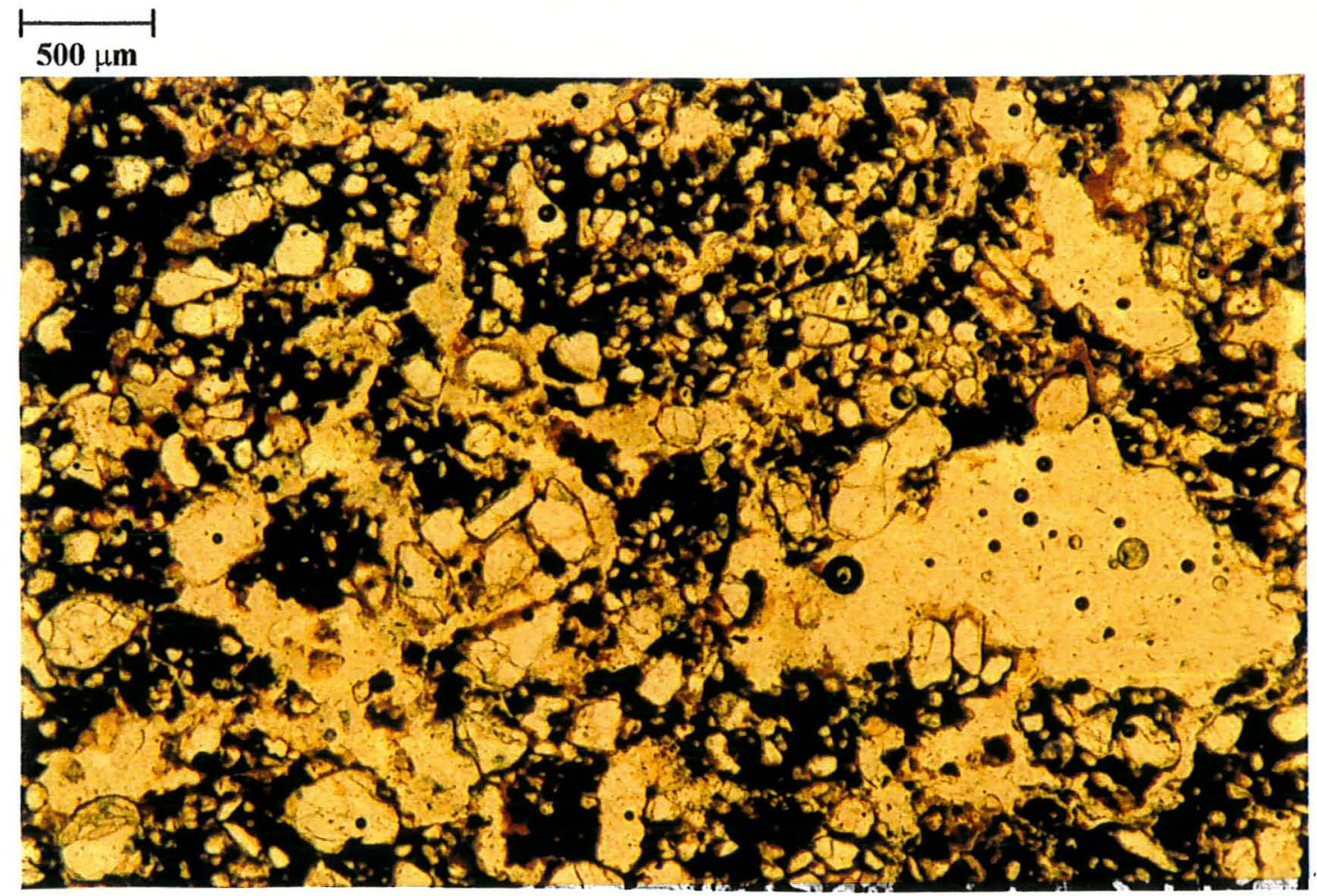

Figura 34. Detalhe da degradação dos agregados porfíricos com o aumento da porosidade cavitária imediatamente abaixo do horizonte plíntico; observa-se também uma possível dissolução dos grãos de esqueleto associados aos poros. A aparência geral é de desmonte ( $\mathrm{LN}-2,5 \mathrm{x})$. 


\subsubsection{Perfil P2}

Este perfil assemelha-se ao P1 em relação aos diferentes mecanismos envolvidos na sua gênese e às características micromorfológicas. No entanto, a presença dos horizonte texturais e de diminutas glébulas no saprolito evidenciam seu maior grau de desenvolvimento.

As lâminas confeccionadas na rocha $(175 \mathrm{a} 185 \mathrm{~cm})$ mostram um fundo matricial com estrutura de base porfirica fechada composta de $40 \%$ plasma, $55 \%$ esqueleto e $5 \%$ de poros. O plasma é de matizes mais vermelhos que o solum e a matriz interglebular, predominando cores vermelhas $(2,5 \mathrm{YR} \mathrm{4/6)} \mathrm{em}$ um fundo matricial silassépico. No entanto, aproximadamente $5 \%$ de seu volume é vermelho-escuro-acinzentado (10 R $3 / 3$ ) e isótico, caracterizando as maiores concentrações de ferro e manganês. A Figura 35 dá uma visão geral desta porção do perfil. Nota-se uma porosidade fissural (diâmetro médio $=0,5 \mathrm{~mm}$ ) com domínios isóticos e enegrecidos nas bordas do poros (neomangãs + neoferrãs) que adentram em alguns milímetros $(\sim 3 \mathrm{~mm})$ na massa porfirica (quasimangãs e quasiferrãs), reduzindo em intensidade a medida que se distancia das fissuras, até o completo predominio das estruturas plásmicas silassépicas e vermelhas. Esses resultados estão de acordo as observações macromorfológicas e analíticas, as quais evidenciaram os maiores conteúdos de ferro e manganês nessa porção do perfil em relação ao demais horizontes estudados (com exceção das glébulas)

Como comentado anteriormente, maiores potenciais oxidantes na porosidade fissural precipitam o manganês, provindos dos locais a montante do perfil, bem como o ferro, mobilizados dos horizontes superiores. A difusão do oxigênio nos poros estendendo-se a poucos milímetros para o interior do fundo matricial, favorecem as condições adequadas de Eh e formação de quasiferrãs e quasimangãs.

Quanto ao esqueleto, este é predominantemente quartzoso, havendo no entanto, 5 a $8 \%$ de feldspatos provenientes dos arenitos subarcosianos do Grupo Bauru. O quartzo mostra-se semelhante em forma e alisamento de suas paredes desde a rocha até os horizontes superficiais, tal como verificado para perfil P1, variando apenas sua granulometria. No entanto, nota-se algumas concentrações isoladas de esqueleto mais 
fino numa matriz também mais argilosa, distribuídos aleatoriamente no fundo matricial desta camada, como pode ser observado na Figura 36. Essas porções ocupam 10 a $15 \%$ do plano da lâmina e com comprimentos que variam de 2 a $7 \mathrm{~mm}$. Suas formas são diversas, predominantemente irregulares e possivelmente estão relacionados ao próprio ambiente deposicional da rocha.

Da rocha para o horizonte $\mathrm{Cr}(140$ a $150 \mathrm{~cm}$ de profundidade) a cor do plasma se mantém, havendo no entanto, um aumento do espaço poral (20\%), constituído basicamente de ortocavidades de $0,1 \mathrm{~mm}$ de diâmetro médio. Feições pedológicas do tipo glébulas já estão presentes nesse horizonte (maior glébula com $0,7 \mathrm{~mm}$ de diâmetro), evidenciando que as condições são adequadas a atual segregação e precipitação do ferro, tal como sugerido para o perfil P1. No entanto, difere deste pela pequena participação de cutãs no fundo matricial. A própria morfologia interna das glébulas evidenciam que argiluviação não é significativa neste horizonte, como veremos posteriormente, uma vez que assemelha-se em estrutura (porfirica fechada) ao fundo matricial do saprolito.

A transição $\mathrm{F} 2 / \mathrm{Cr}$ é marcada pelo aumento significativo da porosidade em relação a base do horizonte $\operatorname{Cr}$ ( $20 \%$ plasma, $30 \%$ esqueleto e $50 \%$ poros). As Figuras 37 e 38 evidenciam essa diferença, mostrando o desenvolvimento da porosidade cavitária no início do horizonte saprolítico $(\mathrm{Cr})$, bem como o desmantelamento da estrutura porfirica, tal como evidenciado para o perfil P1, e portanto, as mesmas interpretações podem ser inferidas aqui. No horizonte F2 essa porosidade reduz-se, porém não de maneira significativa como observado para o perfil P2 (25\% plasma, $35 \%$ esqueleto e $40 \%$ poros). Volumes porfiricos, localmente gefúricos e com uma significativa trama de poros cavitários e canais (orto e meta) são observados em maiores proporções em relação aos volumes predominantemente porfiricos e menos porosos. A Figura 39 evidencia a participação de cutãs de iluviação (ferriargilãs) e de transformação ocupando aproximadamente $5 \%$ do plasma dos volumes com participação gefúrica, bem como uma significativa porosidade composta de cavidades e canais. Em termos gerais, a presença dessas feições pedológicas (cutãs) são menos expressivas nesses horizontes em relação ao perfil P1. 
O horizonte petroplíntico (F1) assemelha-se ao mesmo horizonte do perfil P1. Nota-se no plano da lâmina volumes porfiricos fechados de coloração vermelhoamarelados (5 YR 4/8) com uma pequena porosidade cavitária (10\% de poros). A Figura 40 evidencia esses volumes. No entanto, semelhante ao perfil P1 e diferindo-se do horizonte plíntico abaixo, esses volumes prevalecem em relação aos domínios porfiricos com elevada porosidade.

Além das glébulas, pedotúbulos e ferriargilãs constituem as feições pedológicas do fundo matricial interglebular. Esses últimos ocupam aproximadamente $5 \%$ do total de plasma e muitas vezes mostram-se intensamente ferruginizados, ora assemelhando-se a ferriargilãs zonados complexos (Castro, 1989 e Chauvel, 1979), ora a hematãs, com sua orientação forte e contínua totalmente obliterada devido a ferruginização. A Figura 41 mostra em detalhe esses dois tipos de cutãs e sugere uma origem comum, uma vez que apenas o grau de ferruginização os diferenciam.

Para os horizontes do solum, observa-se que na transição entre Bt2 e F1, já com algumas glébulas, a base do horizonte textural mostrou a menor porosidade (15\% poros, $55 \%$ esqueleto e $30 \%$ plasma) no interior de uma trama porfirica fechada, diferindo da matriz interglebular do horizonte petroplíntico pela ausência de volumes com maior porosidade. A medida que se aproxima da superficie, mas ainda no horizonte $\mathrm{Bt}$, a porosidade é progressivamente aumentada, mantendo-se a trama porfirica que evolui em poucos milímetros para gefúrica e quitônica na transição $\mathrm{E} / \mathrm{Bt} 1$, até a completa permanência da última no horizonte $E$. Nota-se, pela observação das lâminas, o desenvolvimento tanto do espaço poral como da estrutura de base do fundo matricial, evidenciando uma evolução geoquímica na gênese do horizonte $E$, com a coalescência das cavidades e desmonte geral da estrutura porfírica em quitônica devido a remoção de ferro e argila, tal como demonstrado por Castro (1989).

Portanto, a distribuição do sistema poroso e os resultados analíticos evidenciam a participação de uma hidromorfia "suspensa" nos horizontes petroplínticos e a mobilização do ferro, os quais foram responsáveis pela gênese das plintitas e atualmente encontram condições adequadas à sua segregação no horizonte $\mathrm{Cr}$ dos perfis $\mathrm{P} 1$ e $\mathrm{P} 2$ 


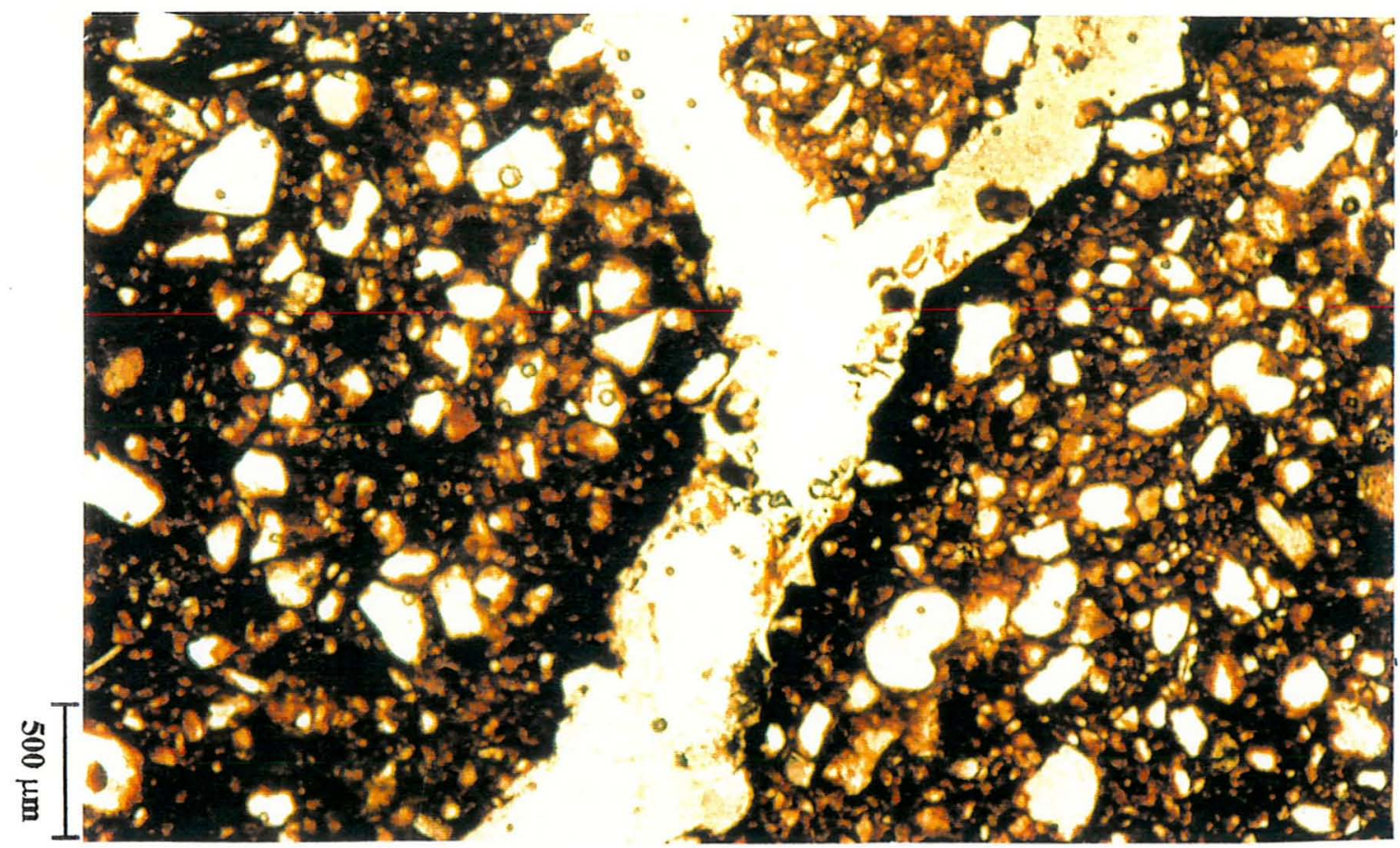

Figura 35. Fotomicrografia da rocha (R) mostrando a porosidade fissural com impregnações de manganês e ferro na sua parede interna (neomangãs e neoferrãs), estendendo-se a poucos milímetros para o interior do fundo matricial (quasimangãs e quasiferrãs) ( $\mathrm{LN}-2,5 \mathrm{x}$ ).

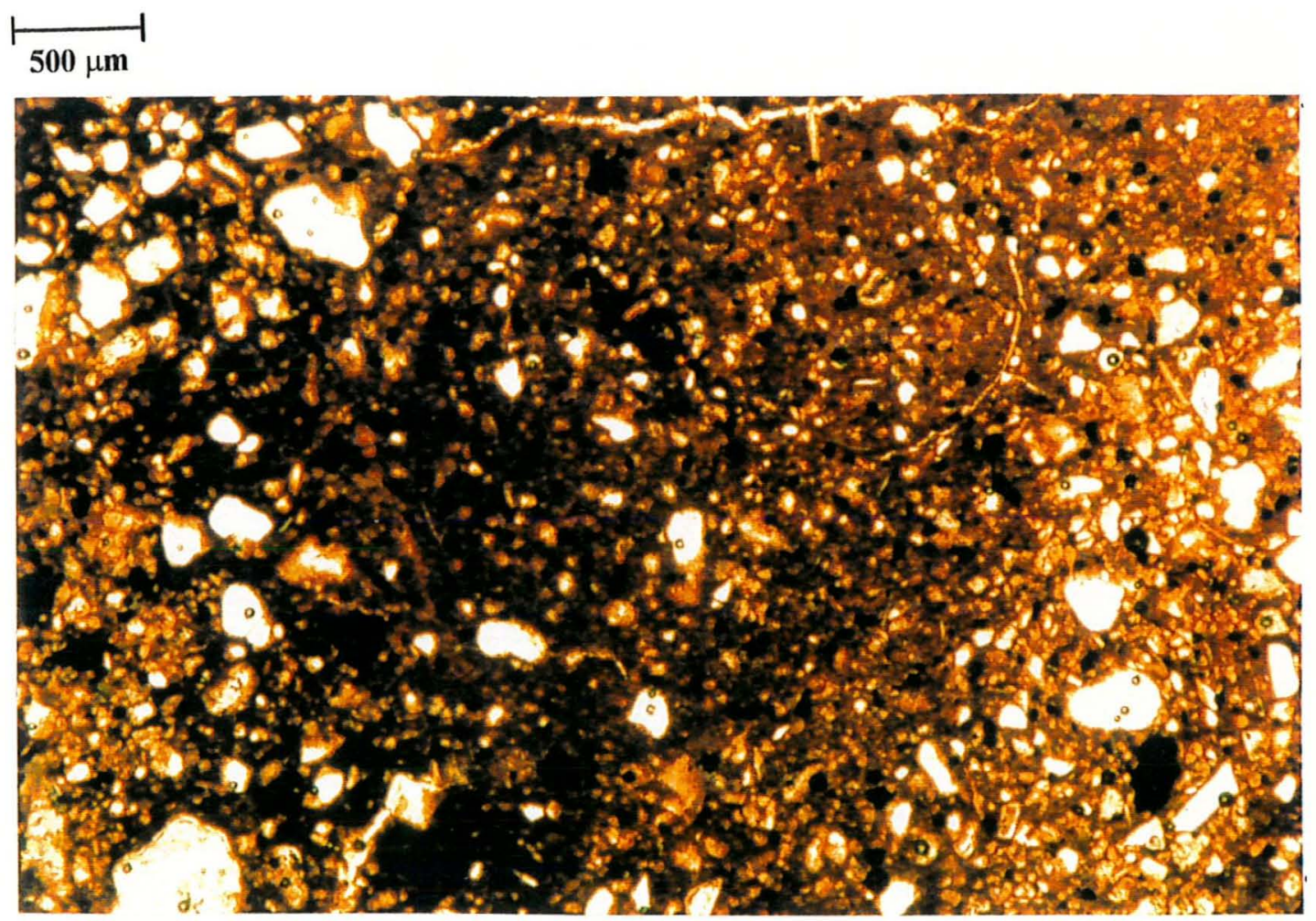

Figura 36. Detalhes do fundo matricial da rocha com porções dominadas por quartzo fino e plasma. Nota-se que a segregação de ferro já é evidente nessa camada e representado por domínios enegrecidos no plano da lâmina (LN - 2,5x). 


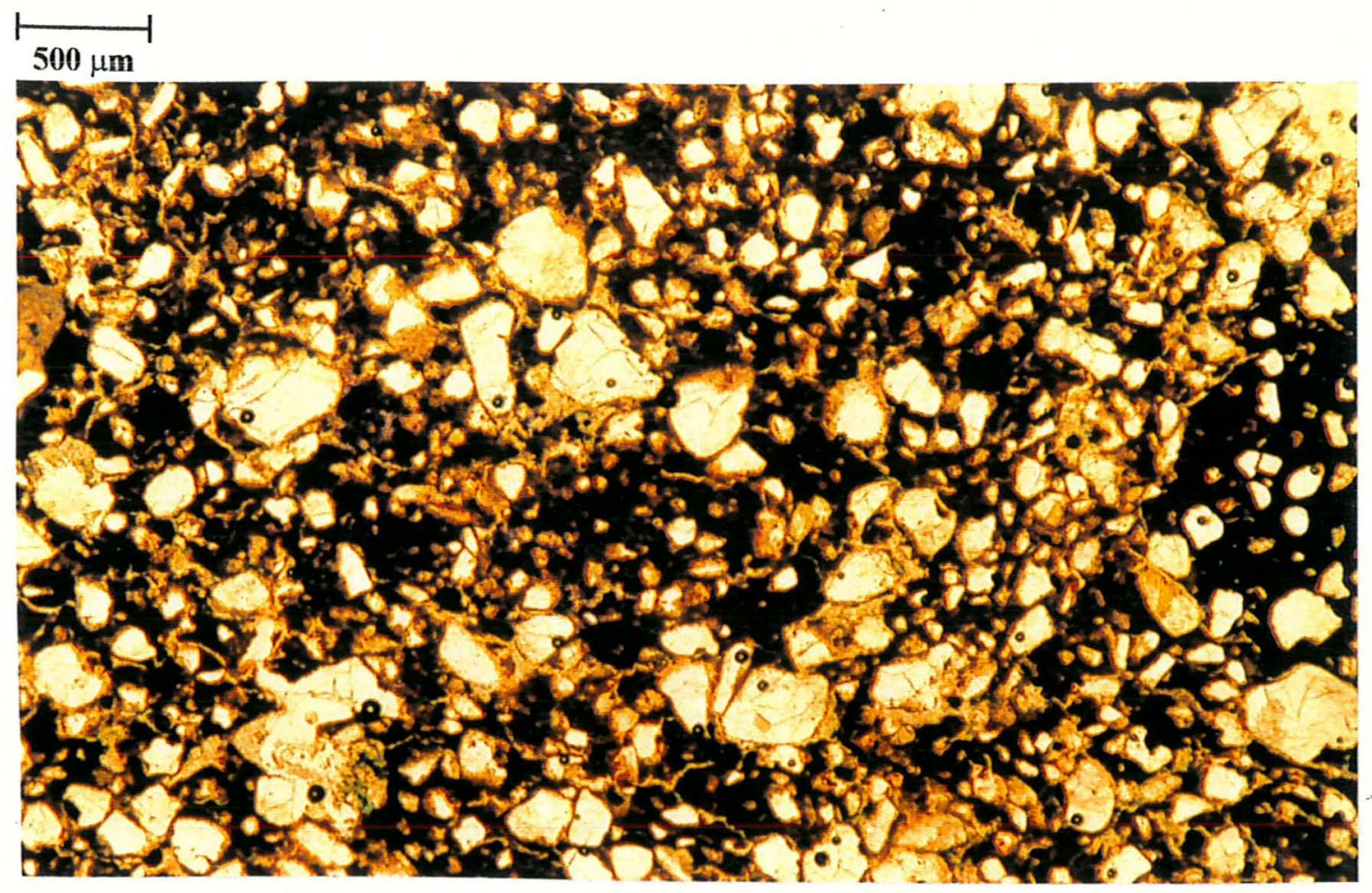

Figura 37. Vista geral da base do horizonte $\mathrm{Cr}(140 \mathrm{~cm}$ de profundidade) no perfil P2. Nota-se a existência de glébulas (à direita) bem como a pequena porosidade cavitária ( $\mathrm{LN}-2,5 \mathrm{x})$.

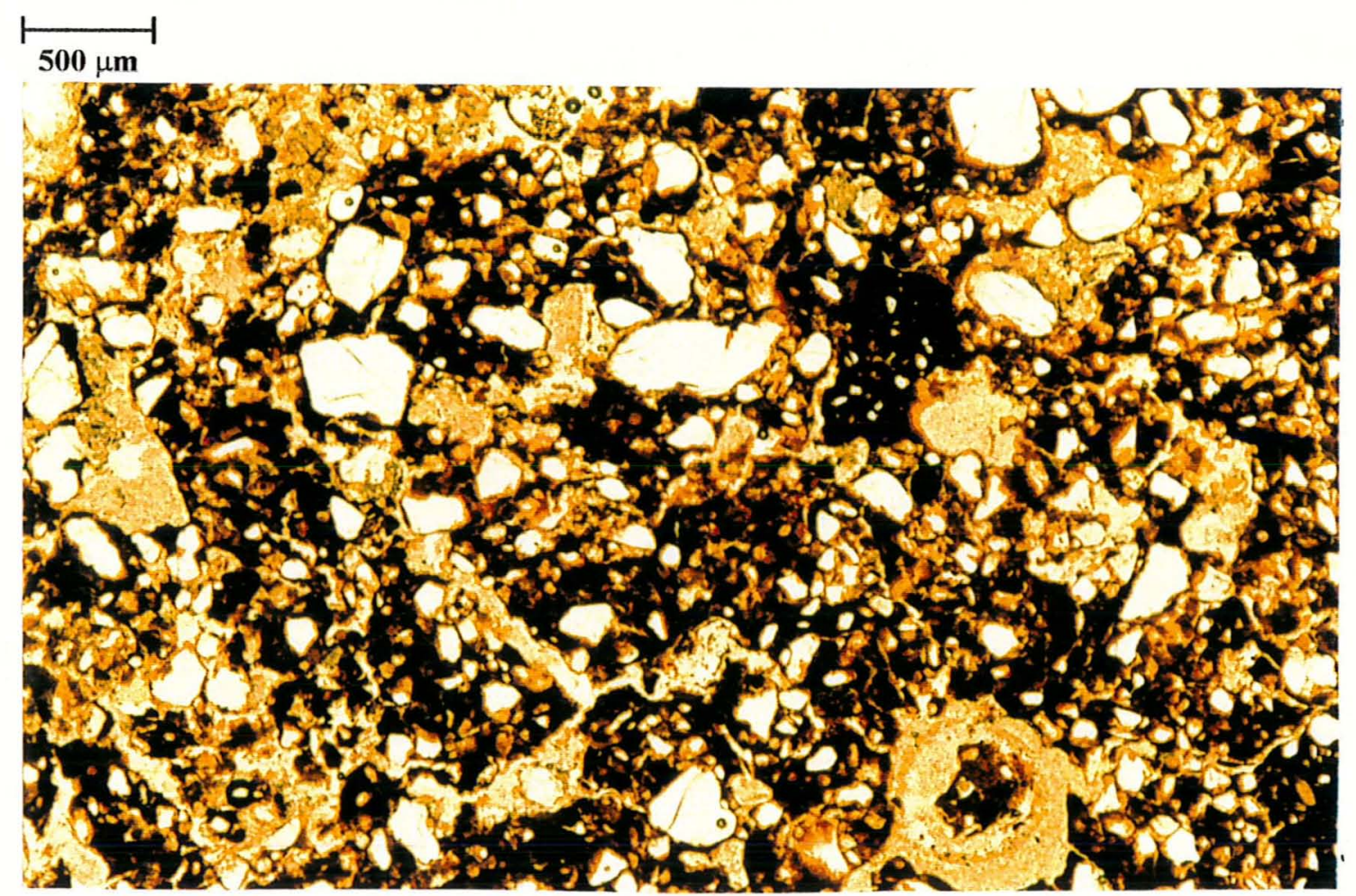

Figura 38. Fundo matricial da transição $\mathrm{F} 2 / \mathrm{Cr}$ evidenciando o aumento da porosidade cavitária e desmonte geral da estrutura porfírica ( $\mathrm{LN}-2,5 \mathrm{x})$. 
A

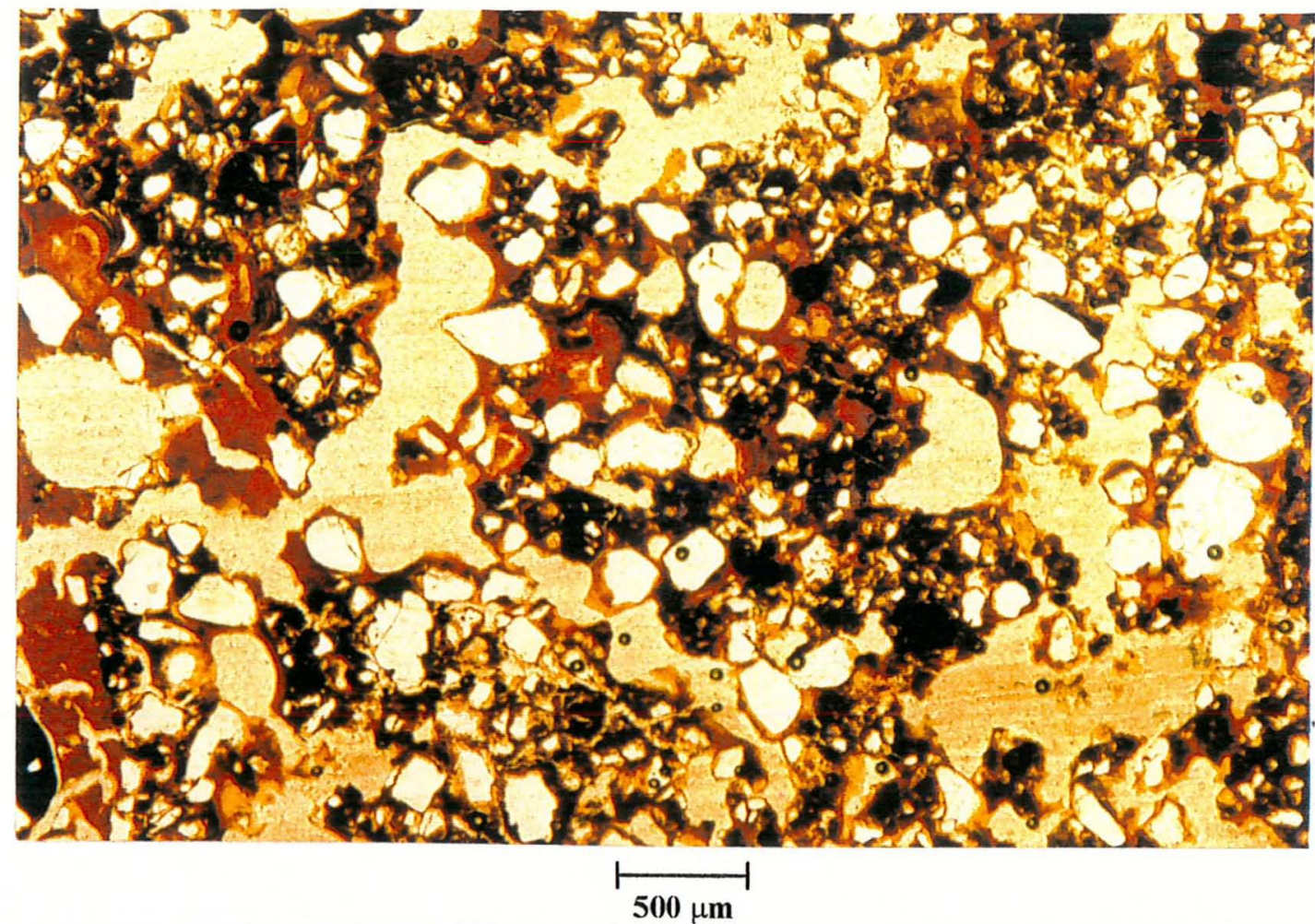

B

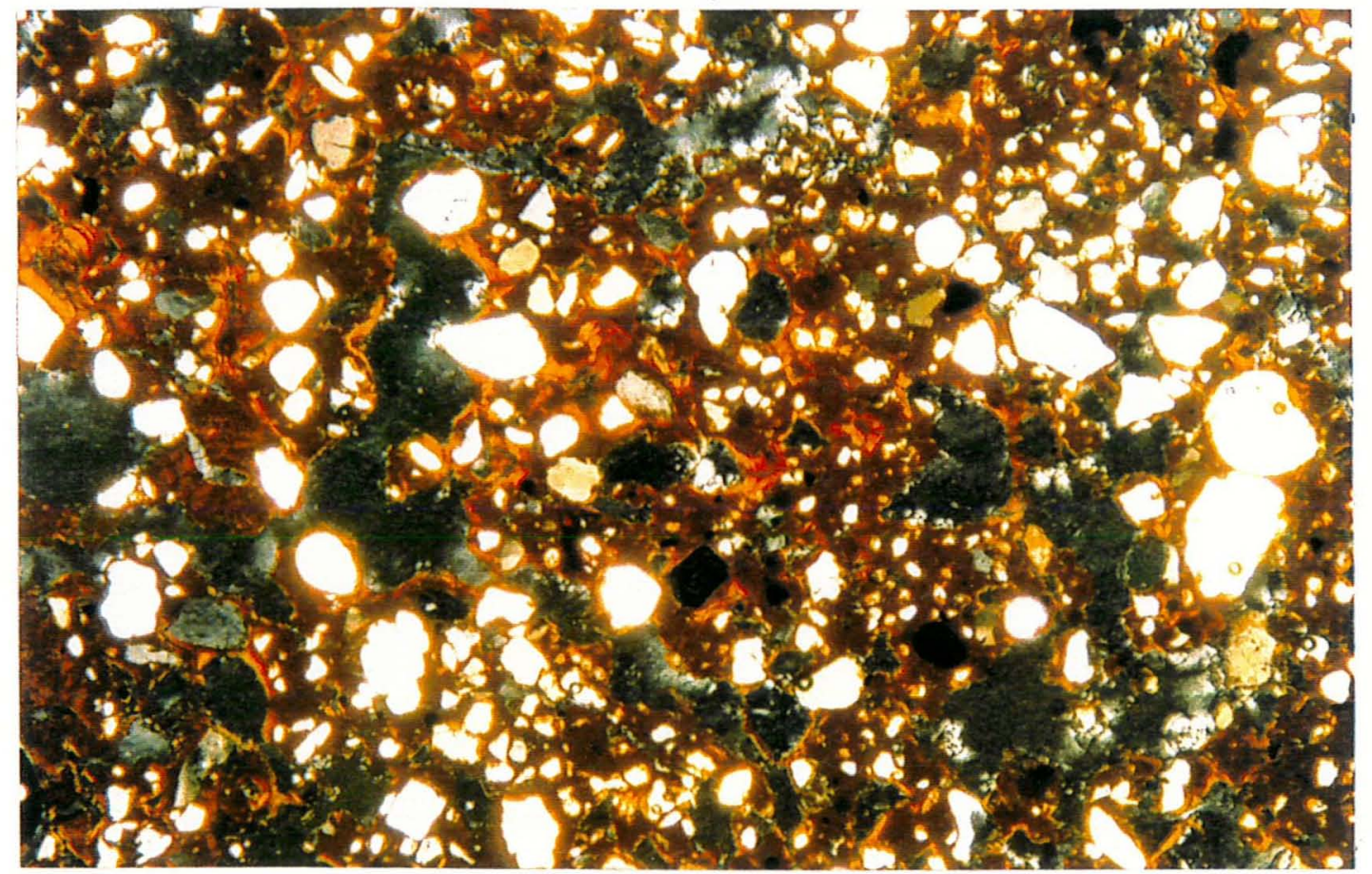

Figura 39. Fotomicrografia do horizonte plíntico (F2) do perfil P2. Nota-se a expressiva porosidade (orto e meta cavidades e canais) e presença de cutãs. Sob nícois cruzados, a orientação forte e contínua discrimina os ferriargilãs de iluviação dos cutãs de transformação. Esses mostram domínios manchados (A - LN; B - LP; 2,5x). 


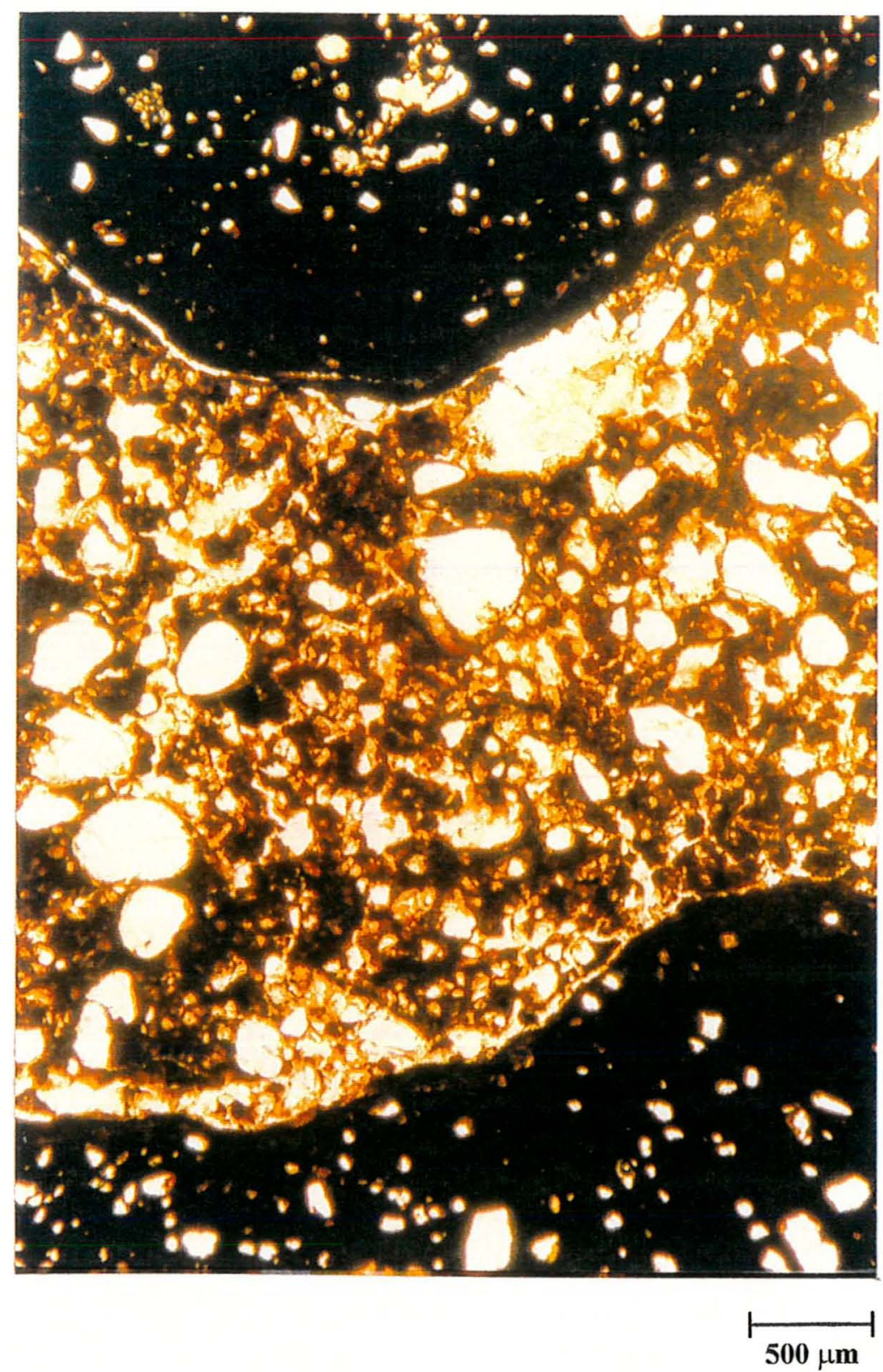

Figura 40. Fotomicrografia da matriz interglebular no horizonte petroplíntico (perfil P2) evidenciando a restrita porosidade predominantemente cavitária. Nota-se também a triagem do esqueleto intraglebular em relação à matriz friável (LN $2,5 x)$. 
A

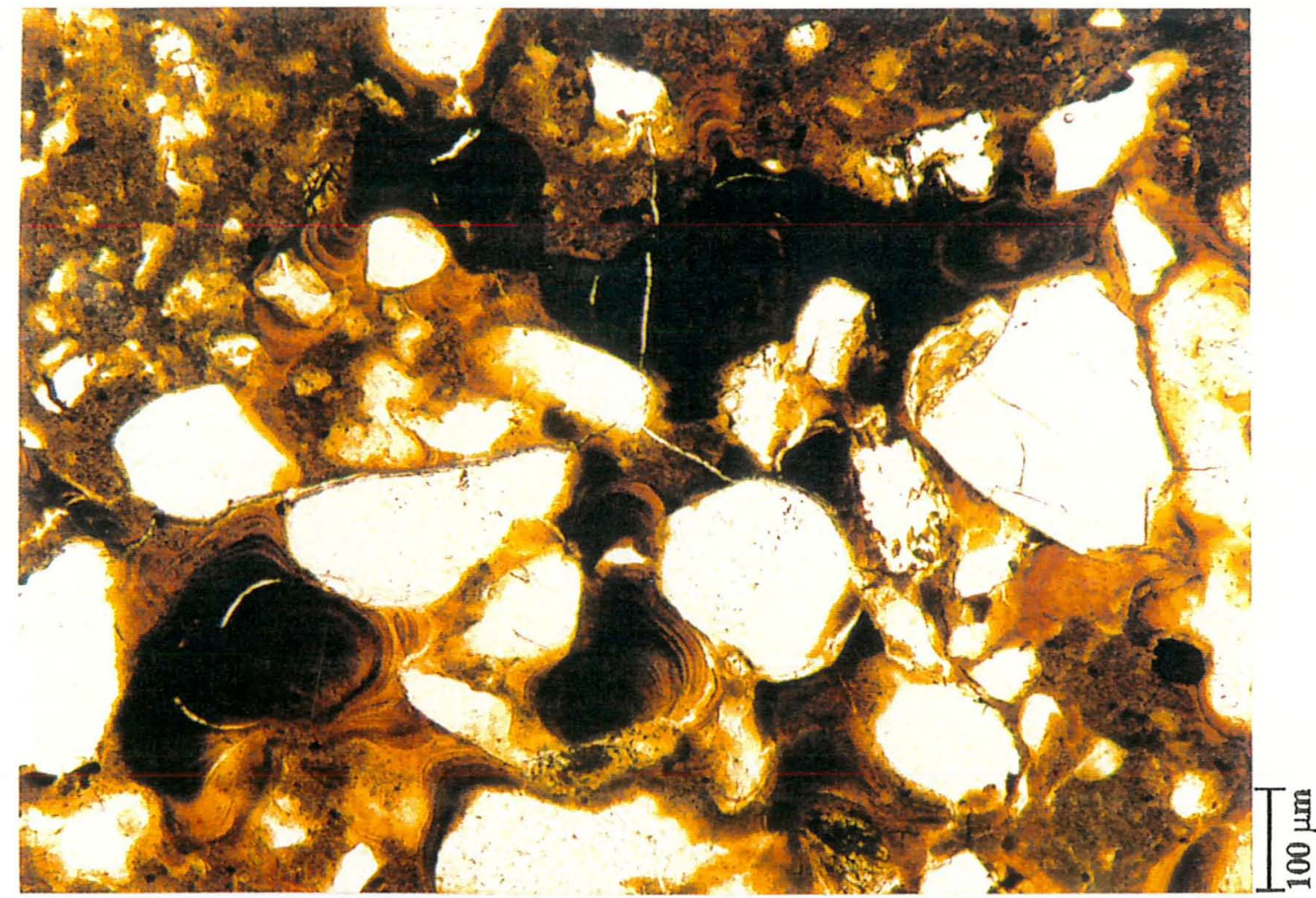

B

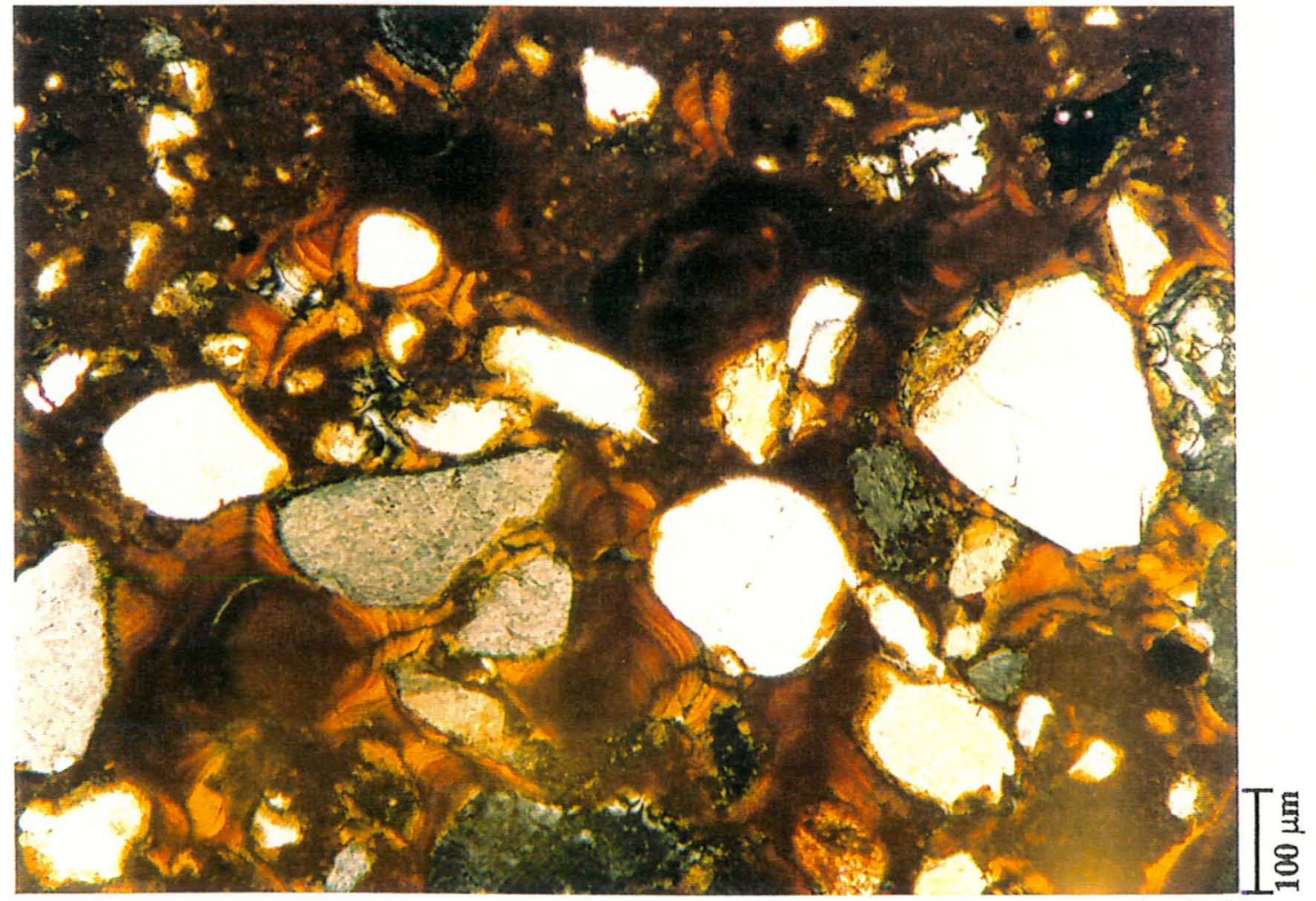

Figura 41. Detalhes dos ferriargilãs de iluviação no fundo matricial interglebular do horizonte petroplíntico (perfil P2). Nota-se os bandeamentos no cutã à esquerda (ferriargilã zonado complexo) e o completo caráter isótico no cutã de cima (hematãs) quando observado sob nícois cruzados. Ambos são ferriargilãs de iluviação intensamente ferruginizados $(\mathrm{A}-\mathrm{LN}$; B - LP; 10x). 


\subsubsection{Perfil P3}

A análise micromorfológica deste perfil evidenciou o desenvolvimento dos mosqueados e confirmou a ausência de glébulas endurecidas. As observações feitas no horizonte Btg2 mostraram que esses apresentam uma trama porfirica fechada com um pequeno desenvolvimento do sistema poroso (10\%) e ocupando aproximadamente $60 \%$ do plano da lâmina, sendo que, o restante $40 \%$ é predominantemente porfirica, mas localmente gefúrica e com uma elevada porosidade cavitária (25\%). Esses distintos compartimentos de estrutura de base no fundo matricial, evidenciam o desenvolvimento dos mosqueados.

A Figura 42 mostra a transição entre um mosqueado e o fundo matricial dominante no plano da lâmina. Nota-se a distinção entre o plasma mais escuro, isótico sob nícois cruzados, e aquele de colorações mais amarelas, com estruturas plásmicas predominantemente silassépica quando observados sob nícois cruzados. Respectivamente, esses representam o mosqueado, onde houve maior segregação de ferro (isótico), e no interior do qual uma menor porosidade se desenvolve, bem como o fundo matricial predominante no plano da lâmina, com maior porosidade e matizes mais amarelos.

Durante a evolução do perfil, a precipitação e aumento da cristalinidade dos óxidos nos períodos secos favorecem a formação do mosqueado, uma vez que tornam-se cada vez mais compactos, menos porosos, possibilitando menores potenciais de oxidação e precipitação de hematita no seu interior sob condições de saturação, conforme sugestões de Tardy \& Nahon (1985). A medida que os processos pedogenéticos evoluem, os mosqueados são totalmente individualizados devido as diferenças de expansão e contração entre eles e o fundo matricial onde estão inseridos (matriz intermosqueado), bem como ao fluxo hídrico preferencial nas suas bordas, favorecendo a remoção do ferro e iluviação das argilas com o desenvolvimento de uma porosidade nos locais de contato, tal como pode ser sugerido da Figura 42 e comentado anteriormente para a formação das plintitas. Essa remoção do ferro, bem como a e-iluviação das argilas na matriz intermosqueados durante a evolução do perfil, também promovem a 
desestruturação de sua estrutura porfirica fechada, com o surgimento de macroporos cavitários e dos volumes com alto valor e baixo croma identificados nas observações de campo. Esses volumes apresentam-se mais amarelos em relação ao fundo matricial, quando observados ao microscópico ótico.

O horizonte Btg1 mostra um aumento significativo da porosidade, predominantemente cavitária, que é acompanhado pelo desenvolvimento de uma estrutura porfirica tendendo a gefúrica localmente. Como os mosqueados estão em menores proporções em relação ao horizonte abaixo, os volumes porfiricos com pequena porosidade também acompanham essa tendência. No entanto, na própria matriz intermosqueados, domínios porfiricos fechados com alguma macroporosidade cavitária se alternam com volumes gefúricos de elevada porosidade cavitária e de arranjo. A Figura 43 mostra essas distintas estruturas de base, evidenciando tanto o desenvolvimento do sistema poroso como a presença de pápulas no fundo matricial porfírico. Essas feições são comuns no plano da lâmina ( $10 \%$ do plasma) e geralmente estão associadas aos grãos de esqueleto fino (silte e areia muito fina), sugerindo uma mobilização conjunta dessas frações no solo. Possivelmente são ferriargilãs de iluviação, impregnados com ferro e por isso mostram uma anisotropia com domínios manchados, bem como são fortemente fissurados, sugerindo "fendas de contração". Essas fendas podem ser atribuídas a desidratação da ferridrita no processo de formação da hematita, segundo indicações de Schwertmann ${ }^{4}$, citado por Debaveye et al. (1987).

A Figura 44 mostra os domínios porfiricos com uma porosidade cavitária irregular se coalescendo, bem como uma trama gefúrica, aparentando um processo de desmonte geral da primeira devido a remoção do ferro e argila. As cavidades geradas podem ser preenchidas com cutãs de argiluviação, como pode-se observar na mesma figura, que posteriormente são ferruginizados (pápulas) e aparentam manter ou promover uma maior resistência das estrutura porfirica ao desmantelamento.

A transição E/Btgl é marcada pelo aumento significativo da porosidade cavitária nos domínios porfiricos, localmente gefúricos. Nota-se a coalescência das cavidades e desmonte geral da trama porfirica em quitônica (Figura 45), tal como sugerido para o

\footnotetext{
${ }^{4}$ SCHWERTANN, U. (1985). Formation of secondary iron oxides in various environments. - In: J.I. DREVER (Ed.). Chemistry of weathering: 119-120. D. Reidel (Publ.)
} 
perfil P2, evidenciando a degradação do topo do horizonte Bt por hidromorfia "suspensa" (Castro, 1989; Jimenez-Rueda \& Demattê; 1988 e Tremocoldi, 1982). Essa fato sugere e corrobora os resultados apresentados na distribuição da freqüência das areias, ou seja, uma origem primordialmente geoquímica e portanto in situ dos horizontes arenosos superficiais na evolução dos perfis, embora afirma-se que muito há de participação coluvionar por todo o perfil.

Dentre as feições ferruginosas, pápulas estão ausentes nessa transição, no entanto, cutãs zonados complexos e simples, bem como hematãs, foram identificados em pequenas proporções ( $1 \%$ do plasma) e apenas nos domínios porfiricos.

Em resposta ao quarto questionamento apontado neste trabalho, podemos sugerir que os horizontes mosqueados presentes no perfil P3 poderiam representar as etapas iniciais no desenvolvimento dos horizontes petroplínticos. No entanto, as evidências micromorfológicas aparentam um desmonte generalizado das estruturas porfiricas nos horizontes texturais do perfil P3, e a partir desse fato podemos sugerir algumas possibilidades envolvidas na gênese dos mosqueados e ferricretes. Primeiramente podemos especular que os aportes atuais de ferro não são suficientes para completa manutenção dessas estruturas porfiricas, necessárias a estabilização e desenvolvimento dos mosqueados que podem evoluir para nódulos e concreções. Assim, os processos pedogenéticos atuantes na evolução do perfil P3 e relacionados a lixiviação e eluviação das argilas e ferro, se sobrepõem à segregação e precipitação do ferro na forma dos mosqueados, sugerindo que a intensidade da ferruginização é que está influenciando na sua formação. Esses mosqueados podem ser reincorporados a estrutura de base porfirica e com menores conteúdos de ferro devido a sua remoção e, portanto, as condições atuais não permitem sua evolução para os horizontes ferricretes como encontramos hoje nos perfis.

Para o horizonte $\mathrm{Cr}$ dos perfis $\mathrm{P} 1$ e $\mathrm{P} 2$, à maior segregação e precipitação do ferro evidenciam o papel desse elemento na manutenção da estrutura de base porfirica fechada, fato que, associado à sua constante mobilização provindo da degradação da petroplintita acima, bem como o estabelecimento de condições adequadas de $\mathrm{pH}$ e Eh $\mathrm{e}$ 
menor intensidade dos processos pedogenéticos nesses locais em relação ao $\mathrm{Bt}(\mathrm{P} 3)$, favorecem a formação atual de nódulos no horizonte.

A ausência de mosqueados nesses perfis sugerem uma origem pretérita aos horizontes petroplínticos, obliterando e reincorporando-os na estrutura dos horizontes após um periodo desfavorável à formação dos ferricretes, onde a intensidade da ferruginização é sobreposta pelos processos pedogenéticos envolvidos na evolução do perfil. Para os horizontes plinticos, podemos especular que a elevada disponibilidade do ferro associado à menor intensidade dos processos pedogenéticos nos horizontes saprolíticos (abaixo do ferricrete), bem como aos maiores potenciais de oxidação, propiciaram a rápida oxidação do ferro e formação das feições plínticas, as quais atualmente encontramos nos perfis. No entanto, para o horizonte $\mathrm{Cr}$ (perfis P1 e P2), essa ausência de mosqueados evidenciam que as condições fisico-químicas adequadas à sua formação são atuais e por isso, nota-se o estágio incipiente de segregação e precipitação do ferro que se encontra esse horizonte no desenvolvimento do ferricrete. 


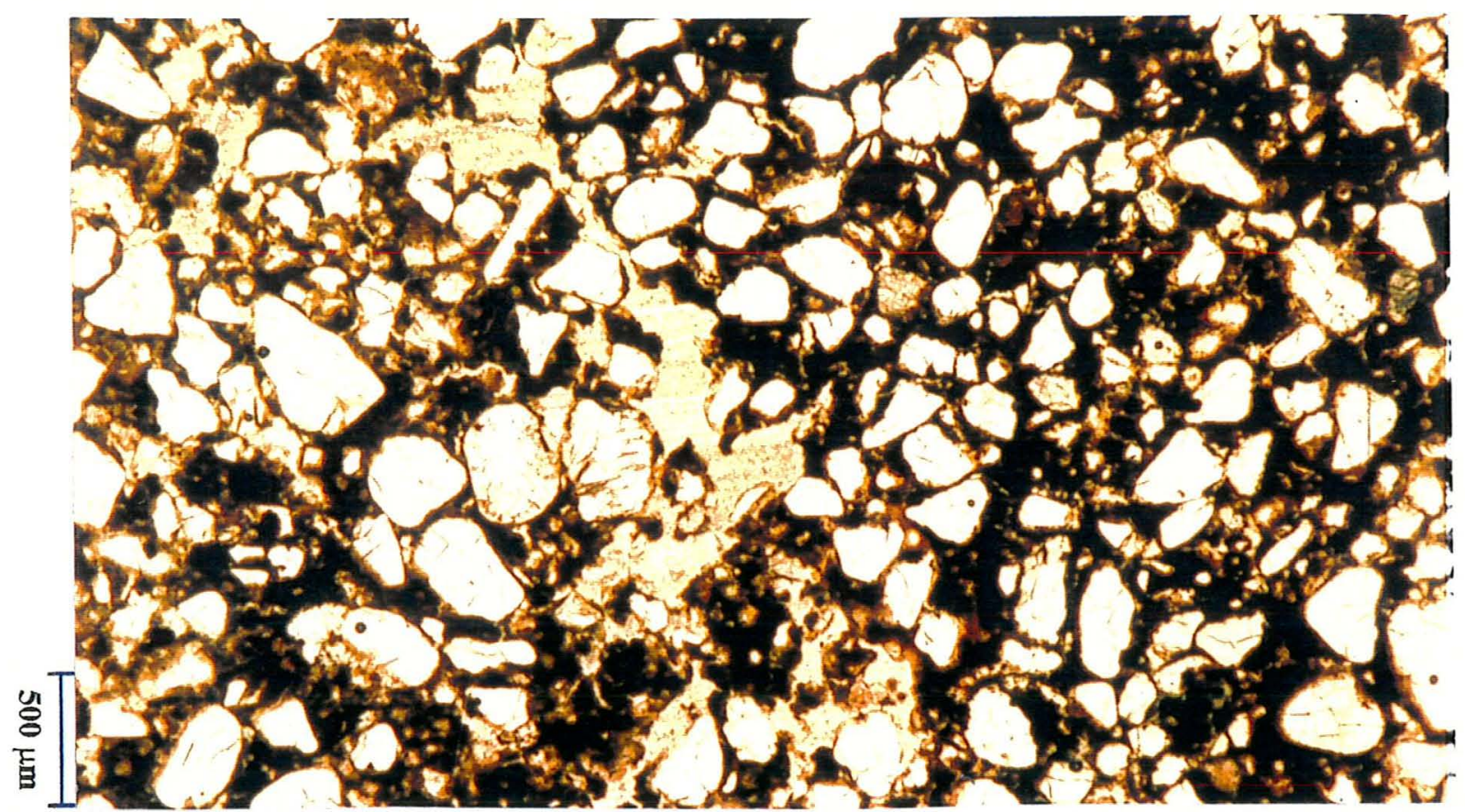

Figura 42. Fotomicrografia do horizonte Btg2 no perfil P3. Nota-se o desenvolvimento de uma porosidade entre o mosqueado à direita e o fundo matricial intermosqueado à esquerda. São evidentes tanto a segregação e precipitação do ferro fornecendo colorações mais escuras, como a pequena porosidade no interior dos mosqueados $(\mathrm{LN}-2,5 \mathrm{x})$

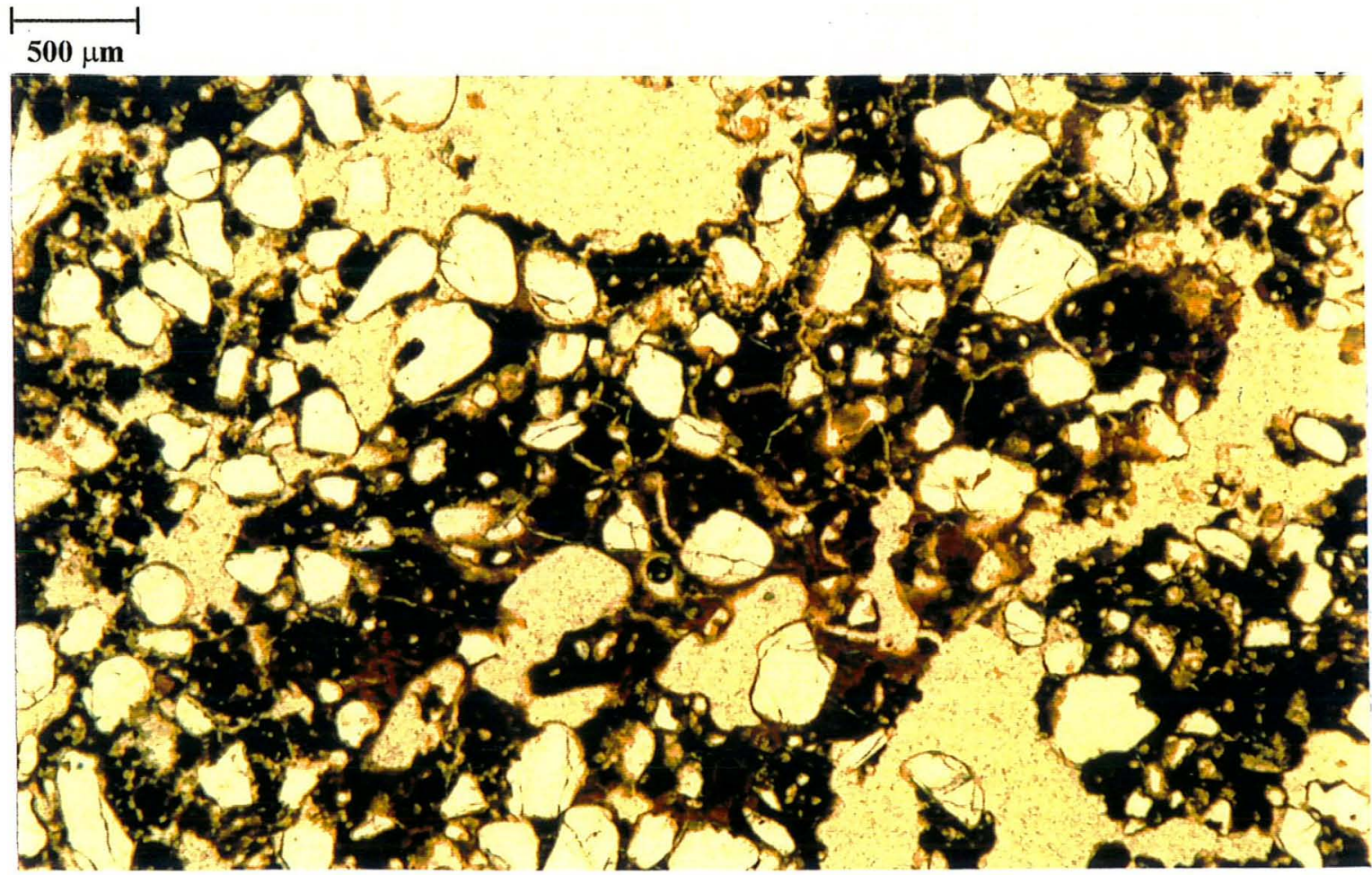

Figura 43. Fotomicrografia do horizonte Btg1 no perfil P3. Detalhes dos domínios porfíricos e gefúricos com uma significativa porosidade cavitária e de arranjo na transição. Nota-se também a presença de pápulas ainda preenchendo totalmente os poros e não integradas ao fundo matricial. Geralmente estão acompanhadas de esqueleto muito fino e siltoso ( $\mathrm{LN}-2,5 \mathrm{x})$. 


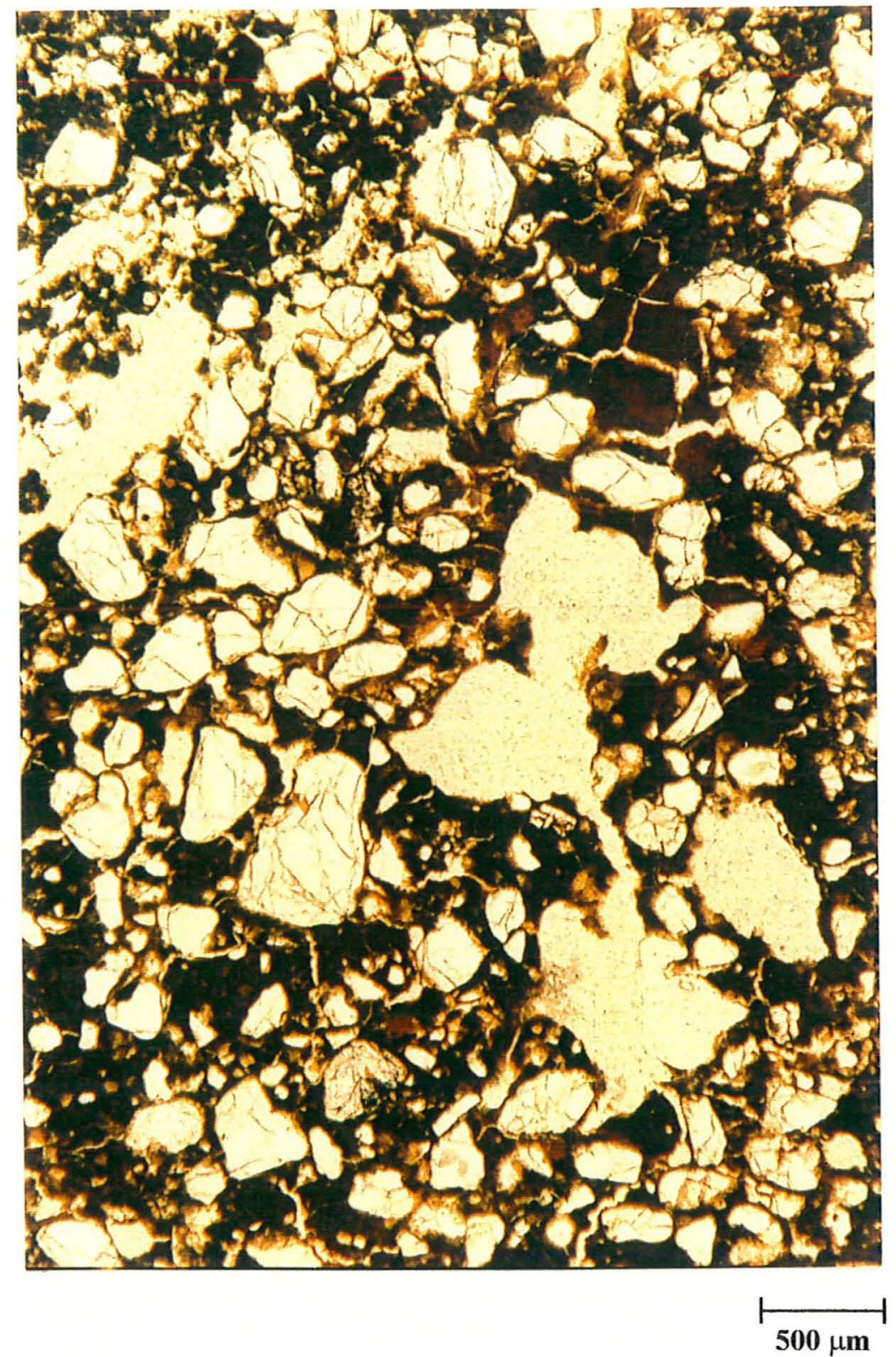

Figura 44. Domínios porfíricos no horizonte Btg1 com uma porosidade cavitária irregular se coalescendo. Nota-se também, estruturas gefúricas e pápulas destituídas de esqueleto quartzoso. A aparência é de desmonte da estrutura porfírica (LN $2,5 x)$. 


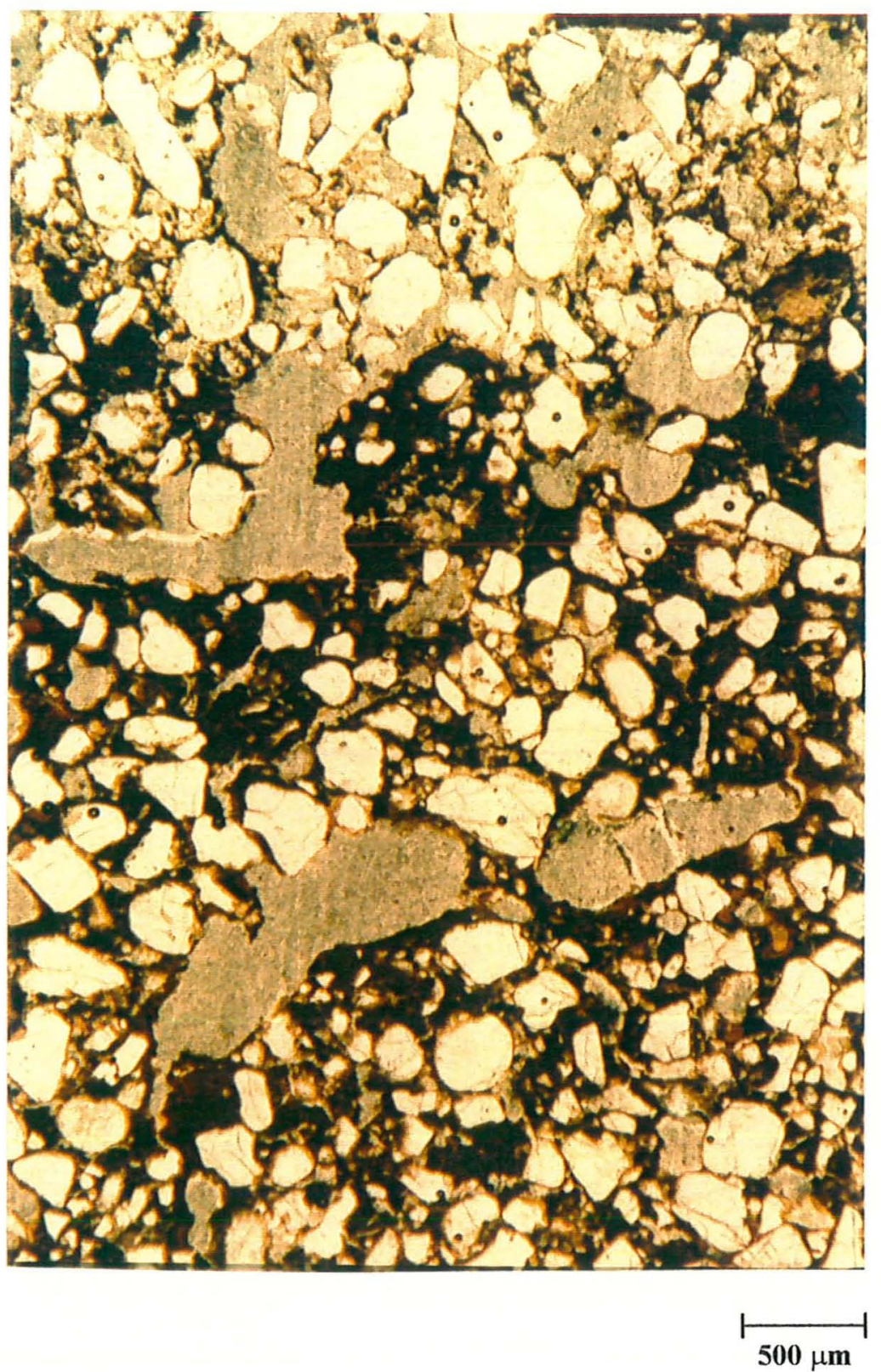

Figura 45. Transição E/Btgl evidenciando a coalescência da porosidade cavitária e a passagem da estrutura porfirica para chitônica $(\mathrm{LN}-2,5 \mathrm{x})$. 


\subsubsection{Glébulas}

\subsubsection{Morfologia}

Os parâmetros morfológicos utilizados neste trabalho seguem as sugestões de Brewer (1976).

\section{a) Morfologia externa}

A maioria das glébulas mostram-se irregulares quanto a morfologia externa, portanto sem formas definidas. Segundo Brewer (1976) essa morfologia é indício de uma origem in situ. Quanto a individualização, apresentam limites muito nítidos com o fundo matricial interglebular, caracterizando-as como discretas e fracamente aderentes. Não há diferenças entre as glébulas plínticas e petroplínticas quanto a morfologia externa, bem como entre os diferentes perfis.

\section{b) Morfologia interna}

Internamente as glébulas classificam-se como indiferenciadas. $\mathrm{O}$ córtex milimétrico verificado nas observações de campo é indiferenciado nas análises micromorfológicas. No entanto, $60 \%$ das glébulas petroplínticas mostram um córtex de aproximadamente $0,15 \mathrm{~mm}$ e de coloração marrom ou amarelada e que estão ausentes nas plínticas. Esse fato será discutido posteriormente. Além dessa diferença, algumas plintitas não são completamente isóticas e apresentam uma certa anisotropia no seu interior associada à colorações mais amareladas. A Figura 46 evidencia essa diferença, salientando a presença de matizes mais amarelos em algumas glébulas plínticas.

Apesar de classificá-la como indiferenciadas, o que significa afirmar que seus constituintes não apresentam uma orientação específica, a grande maioria das glébulas examinadas no plano das lâminas (aproximadamente $70 \%$ ) mostram domínios ou volumes internos ocupados ou por esqueleto de diferente granulometria em relação ao restante da glébula, ou apenas plasma. Também, é bastante comum a ocorrência de glébulas inteiras com uma granulometria interna dominada por esqueleto na fração areia muito fina $(100 \mu \mathrm{m})$, enquanto glébulas vizinhas, muito próximas, bem como a matriz 
interglebular, o esqueleto está predominantemente na fração areia média $(200 \mu \mathrm{m})$. As Figuras 47 e 48 evidenciam essas assertivas. Glébulas com um fundo matricial de diferentes granulometrias do esqueleto também são freqüentes no plano da lâmina. Segundo a classificação de Brewer (1976) todos essas feições ferruginosas aqui descritas são enquadradas como nódulos devido à sua fábrica interna indiferenciada.

Da descrição morfológica desses materiais podemos inferir alguns mecanismos envolvidos na sua gênese. A presença de nódulos com o esqueleto triado e de diferentes granulometrias (Figura 48) desenvolvidos lado a lado no horizonte ferricrete e que também diferem do fundo matricial interglebular, podem sugerir uma origem detrital ou alóctone. Brewer (1976) propõe que se observe o contraste entre o material da fábrica interna das glébulas e o seu entorno. Quando são diferentes o autor classifica-os como anórtico e afirma que esses nódulos são alóctones, ou seja, sua gênese está associada à formação em pedoambientes diferenciados e que, por transporte e deposição, originam feições com diferentes fábricas internas em relação ao fundo matricial interglebular. No entanto, essa hipótese não é válida para esses materiais em estudo, uma vez que existem evidências de dominios com esqueleto triado no fundo matricial dos diferentes horizontes saprolíticos, matriz interglebular e rocha.

Diferentes mecanismos podem estar associados ao selecionamento do quartzo ou redução de sua granulometria no solo e saprolito. A própria origem litogenética, como evidenciado na Figura 36, pode estar condicionando domínios ocupados com quartzo mais fino nos diferentes horizontes dos perfis. Outro mecanismo pode estar associado a iluviação de plasma e esqueleto fino, tal como evidenciado anteriormente, depositados nos macroporos e posteriormente incorporados ao nódulo durante sua formação. Também, a dissolução do quartzo nos pedoambientes de maior fluxo hídrico podem ser responsáveis pela sua redução no tamanho (Figura 34); e finalmente, podemos sugerir que a atividade biológica exerce uma participação no desenvolvimento de glébulas com esqueleto triado e de menores dimensões. A Figura 49 mostra uma glébula plíntica (perfil P2) com grãos de esqueleto de maiores dimensões alinhados e separando uma porção com quartzo fino de outra, com esqueleto de diferentes granulometrias. Isso sugere a 
existência de um pedotúbulo que foi incorporado ao fundo matricial e posteriormente ferruginizado na gênese das glébulas. Inúmeros isotúbulos foram identificados em todos os horizontes dos perfis, alguns deles com esqueleto triado e de pequenas dimensões.

A presença de domínios ocupados com apenas plasma no interior das glébulas sugerem a participação dos mecanismos de iluviação na sua formação. Conforme sugestões de vários autores, o desenvolvimento de uma macroporosidade no saprolito é acompanhado pelo seu preenchimento com argila secundária ou proveniente da argiluviação. Esses processos caracterizam as etapas iniciais na formação de nódulos e concreções ferruginosas (Bellinfante et al., 1970 e Nahon, 1986) e aparentam ser procedentes nas glébulas estudadas. As Figuras 50 e 51 são as que melhor evidenciam a participação da iluviação de argila na gênese dos ferricretes. Nota-se a presença de plasma no interior da glébula (Figura 50), com esqueleto fino (areia muito fina e silte) no córtex de uma lado (borda esquerda) e frações mais grosseiras noutro (direita). Possivelmente, a deposição de argila e sua ferruginização por difusão foi anterior, preenchendo o canal biológico gerado no interior do saprolito. As formas aproximadamente arredondadas do volume constituído essencialmente de plasma, sugerem a participação biológica na sua formação. Com a evolução do perfil, o estabelecimento dos processos diferenciados de expansão e contração entre o plasma ferruginizado e a matriz, bem como o fluxo preferencial de água no seu entorno, favorece o desenvolvimento de uma nova porosidade nas bordas, as quais foram desta vez, preenchidas com plasma e quartzo fino, eluviado dos horizontes superiores ou das proximidades e que sofreram posterior difusão de ferro provindo dos volumes constituídos de apenas plasma e ferruginizados. As fendas no interior da glébula e nos volumes ocupados com plasma, são de contração. Conforme comentado anteriormente, a desidratação da ferridrita em hematita é acompanhada por uma redução de volume, promovendo o desenvolvimentos dessas fendas e que posteriormente podem ser preenchidas com a evolução da glébula.

A Figura 51 também evidencia a influência da iluviação e da atividade biológica na formação dos nódulos. Nota-se alguns volumes dominados por plasma apenas, 
enquanto outros, formam verdadeiros "corredores" preenchidos com quartzo fino e argila. Possivelmente esses "corredores" de quartzo fino e plasma são paleo-pedotúbulos, enquanto os dominios ocupados com plasma apenas, correspondem a canais biológicos os quais foram posteriormente preenchidos com ferriargilãs ou hematãs e ferruginizados durante a gênese da glébula.

Além da argiluviação com posterior ferruginização, a colmatação da macroporosidade com géis de ferro seria outro mecanismo envolvido na gênese das glébulas, favorecendo a difusão do $\mathrm{Fe}^{2+}$ para a matriz vizinha. Aportes do elemento provindo dos horizontes superiores complementariam a segregação do ferro, originando as glébulas identificadas nas Figuras 50 e 51 . No entanto, análises submicroscópicas e de microssonda nas lâminas, em alguns desses domínios constituídos de plasma, identificaram a presença de $\mathrm{Fe}, \mathrm{Al}$ e $\mathrm{Si}$ como constituintes, sugerindo uma formação também caulinitica para esses materiais. Esse fato corrobora o papel da argiluviação durante a gênese dos nódulos. 

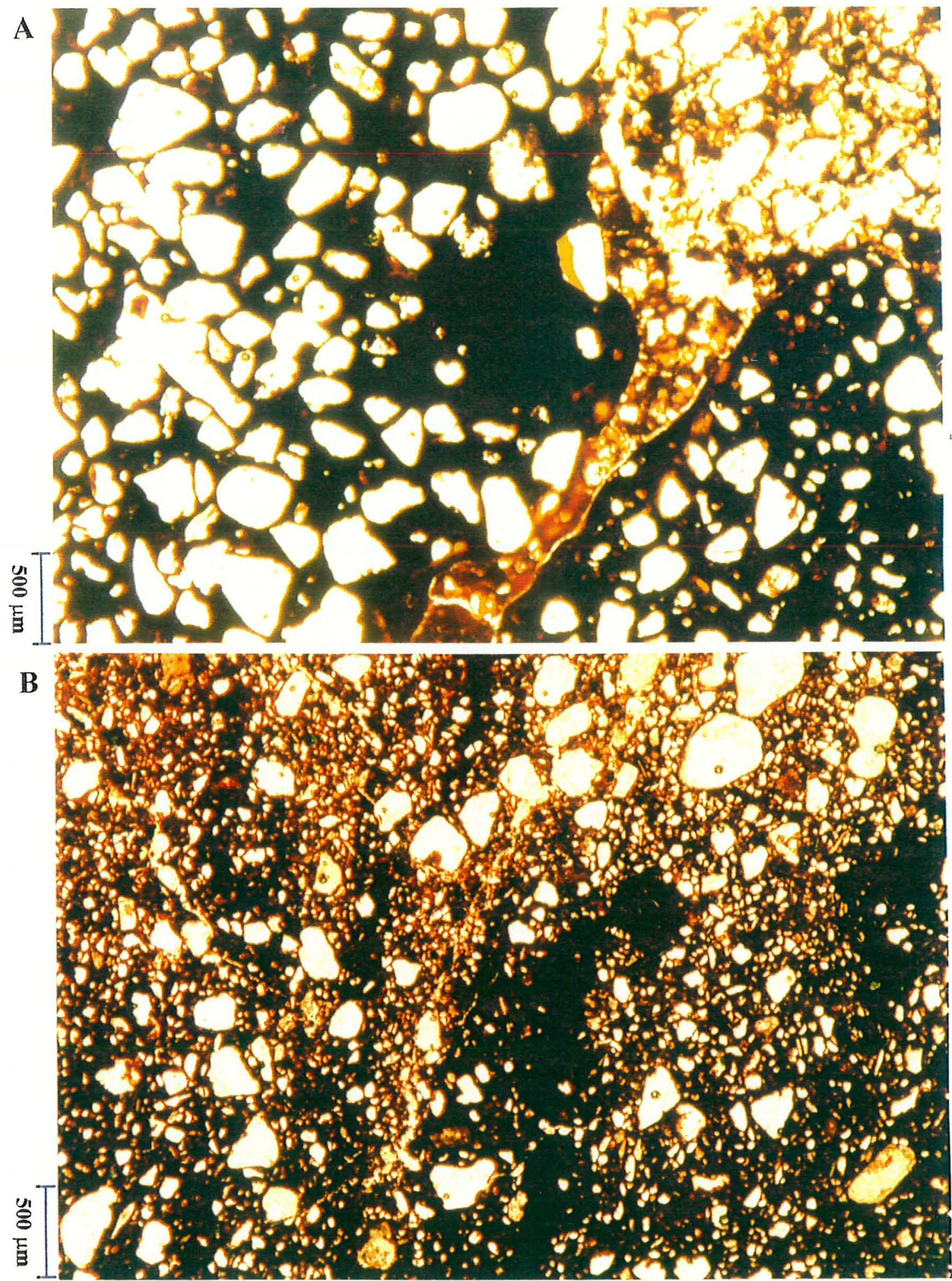

Figura 46. Morfologia interna das glébulas petroplínticas (A) e plínticas (B). Nota-se a presença de matizes mais amarelos nas plintitas $(\mathrm{LN}-2,5 \mathrm{x})$. 

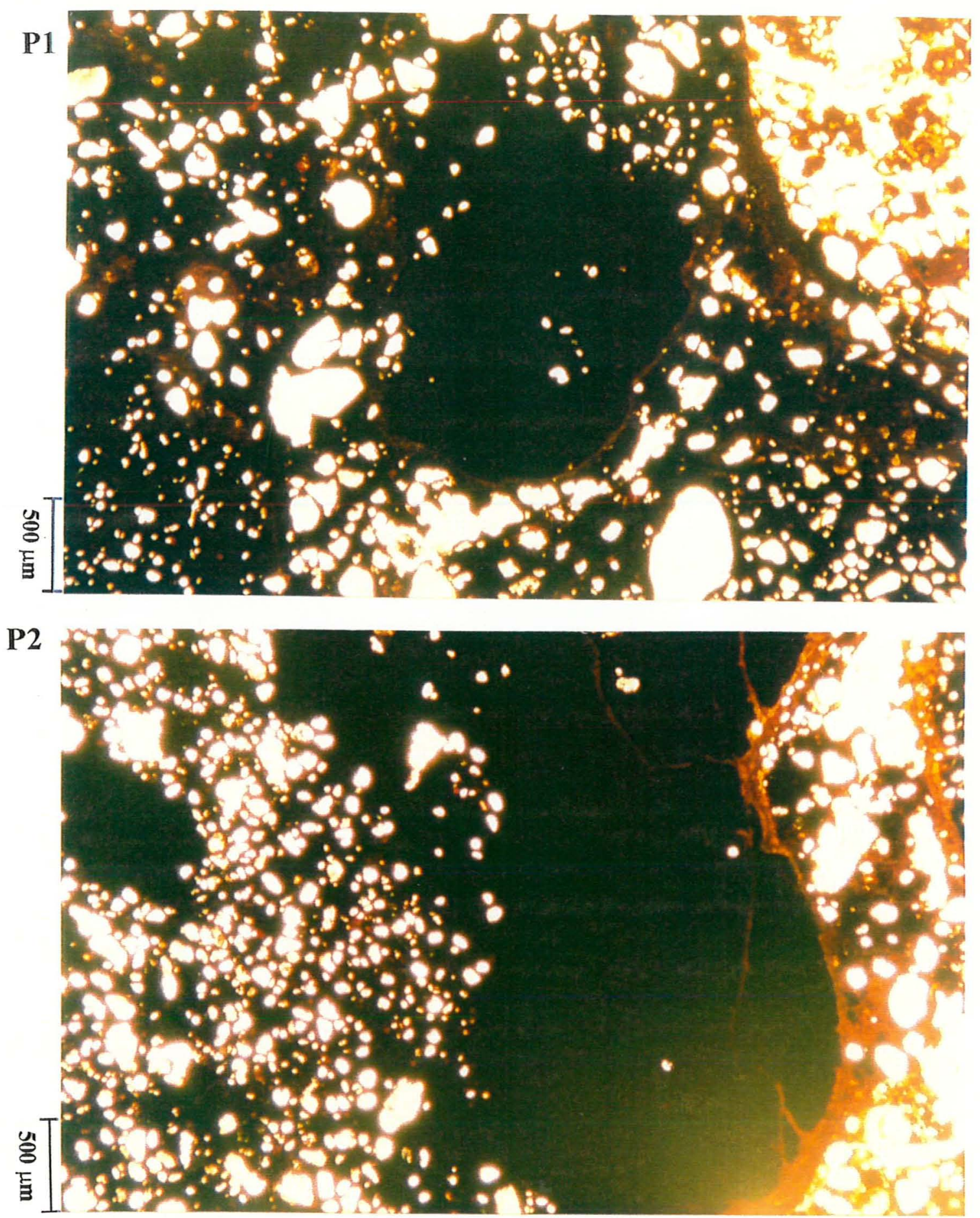

Figura 47. Fotomicrografia das glébulas petroplinticas dos perfis P1 e P2 evidenciando a presença de domínios internos ocupados somente com plasma e pouco esqueleto fino (perfil P1). No entanto, algumas poucas glébulas (perfil P2) também mostram um córtex dominado por plasma e com sua matriz interna predominantemente na fração esqueleto muito fino (LN $2,5 x)$. 

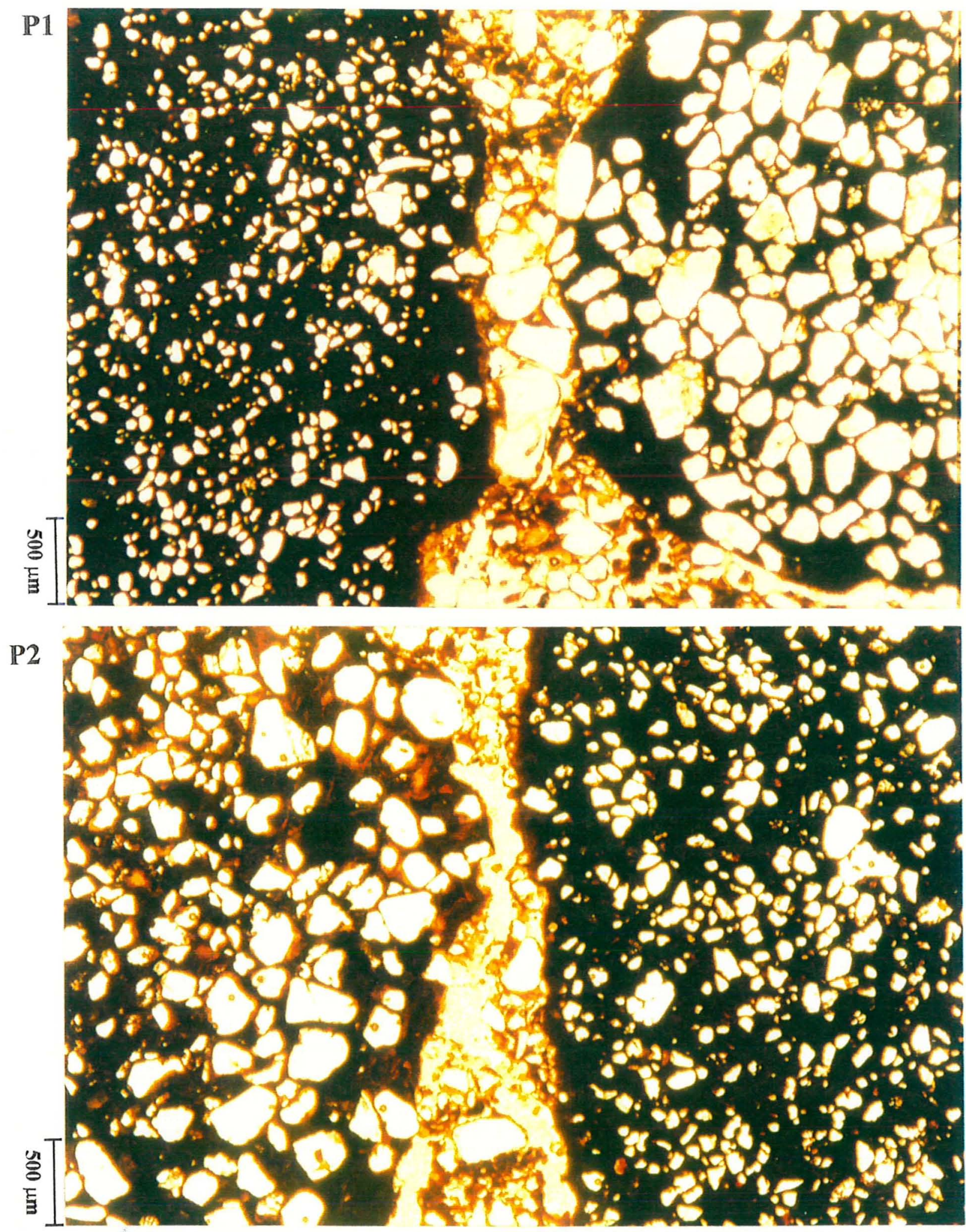

Figura 48. Fotomicrografia mostrando glébulas com diferentes granulometrias do esqueleto, presentes lado a lado nos horizontes petroplínticos dos perfis P1 e P2 ( $\mathrm{LN}-2,5 \mathrm{x})$. 


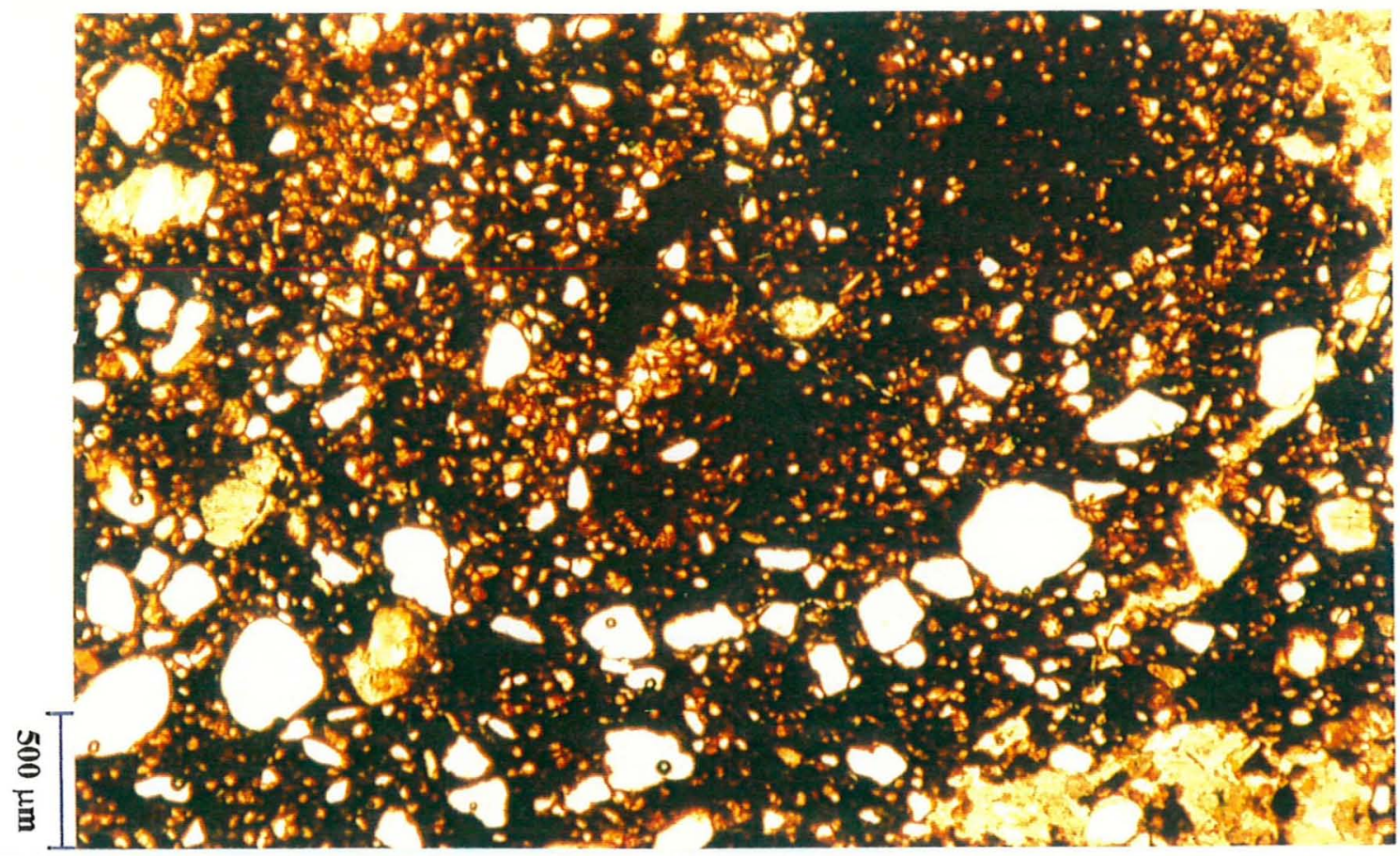

Figura 49. Fotomicrografia de uma glébula plíntica do perfil P2 evidenciando sua origem associada a atividade biológica. Nota-se o alinhamento dos grãos de esqueleto separando os volumes com quartzo mais fino daqueles de maiores dimensões. O domínio com esqueleto fino corresponde a um pedotúbulo, o qual se encontra totalmente ferruginizado em alguns locais ( $\mathrm{LN}-2,5 \mathrm{x}$ ).

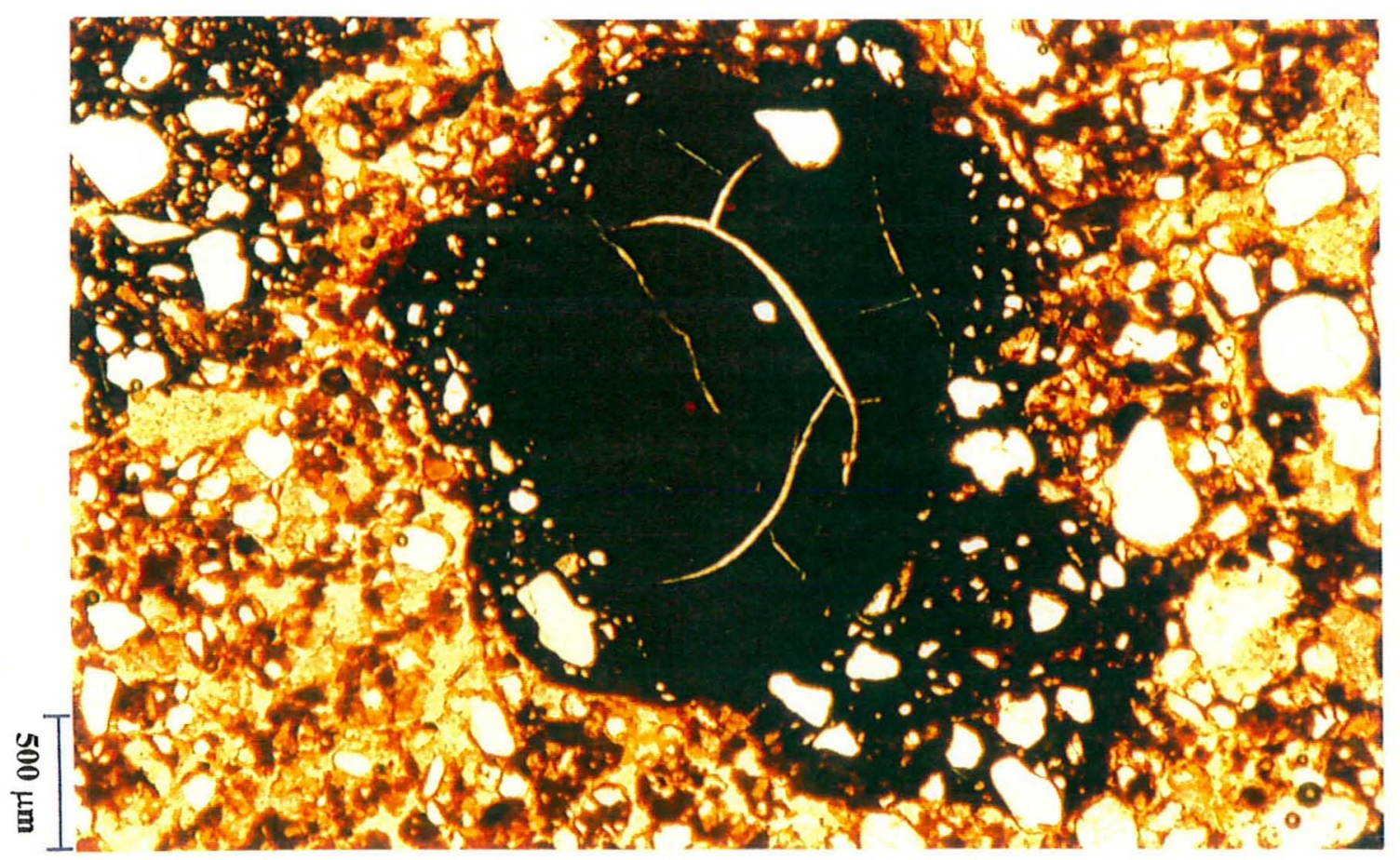

Figura 50. Glébula plíntica do perfil P2. Nota-se o desenvolvimento de plasma no seu interior e esqueleto fino no córtex. As formas aproximadamente arredondadas sugerem paleocanais biológicos, os quais foram posteriormente preenchidos com géis de ferro ou argila iluviada, com posterior ferruginização. Fendas de contração são evidentes nos domínios ocupados por plasma apenas $(\mathrm{LN}-2,5 \mathrm{x})$. 


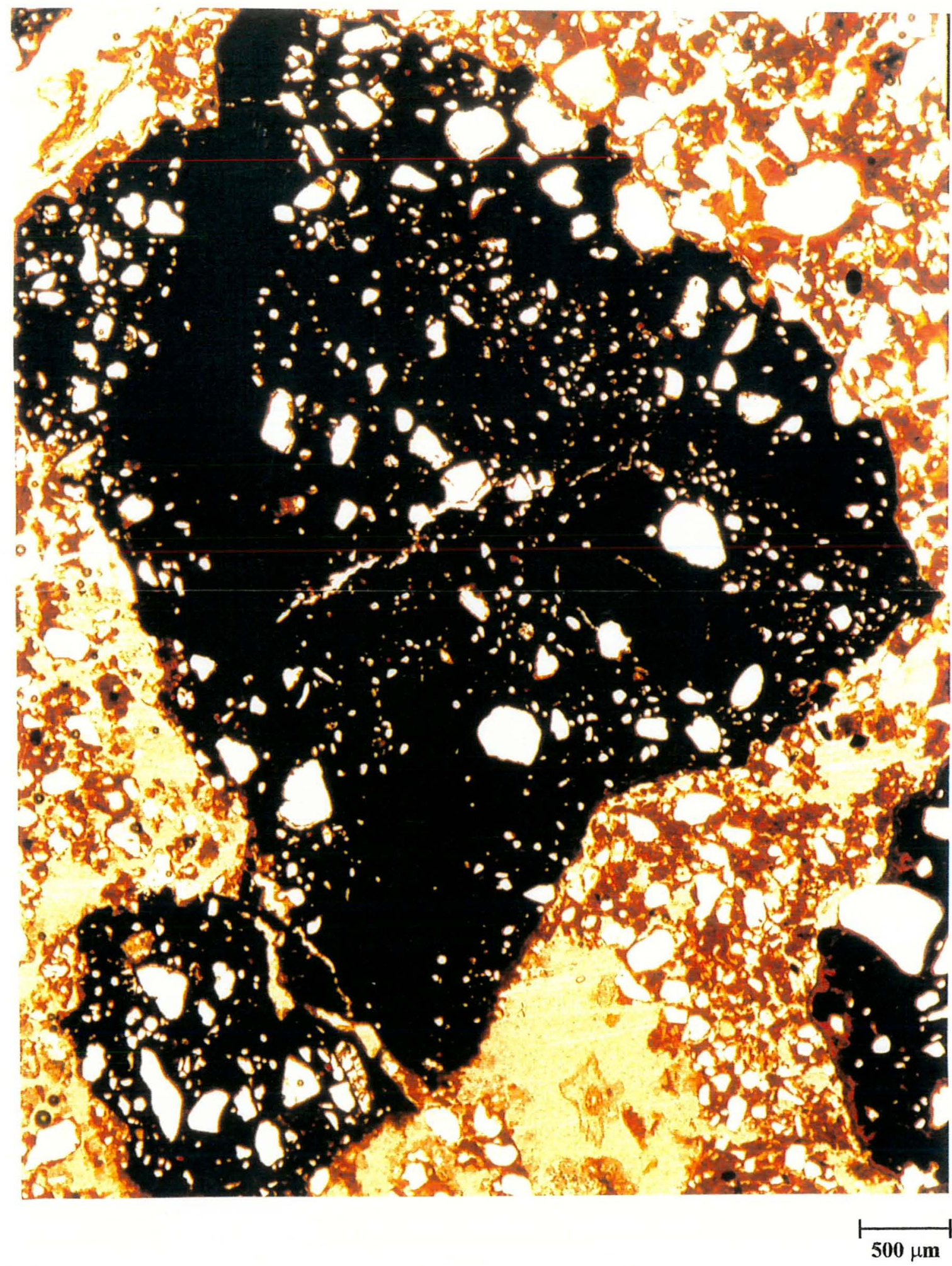

Figura 51. Fotomicrografia mostrando uma glébula plíntica no horizonte $\mathrm{Cr}$ (perfil P2). Domínios ocupados com plasma apenas "cruzam" como verdadeiros "corredores" de quartzo fino (pedotúbulos) e plasma (canais biológicos). Essa morfologia só é explicada pela atuação da atividade biológica ( $\mathrm{LN}-2,5 \mathrm{x})$. 


\subsubsection{Degradação}

Couraças nodulares em estágio de desmantelamento originam os chamados pisolitos de degradação, caracterizados pela presença de córtex goetítico (Tardy, 1993). Segundo Beauvais e Colin (1993) corresponde ao último estágio de desenvolvimento dos ferricretes, onde se desenvolve um córtex ou uma trama marrom entorno ou dentro dos nódulos hematíticos. As Figuras 52 e 53 evidenciam essas feições de dissolução. Nota-se a coloração predominantemente amarelada, sugerindo a dominância de goetita, bem como a presença de esqueleto muito fino no córtex. Plasma e esqueleto fino são liberados das glébulas e incorporados ao fundo matricial interglebular, aumentando tanto seu conteúdo de ferro e argila como de quartzo na fração areia muito fina, tal como evidenciado nos resultados de granulometria, dissolução seletiva e distribuição da freqüência das areias.

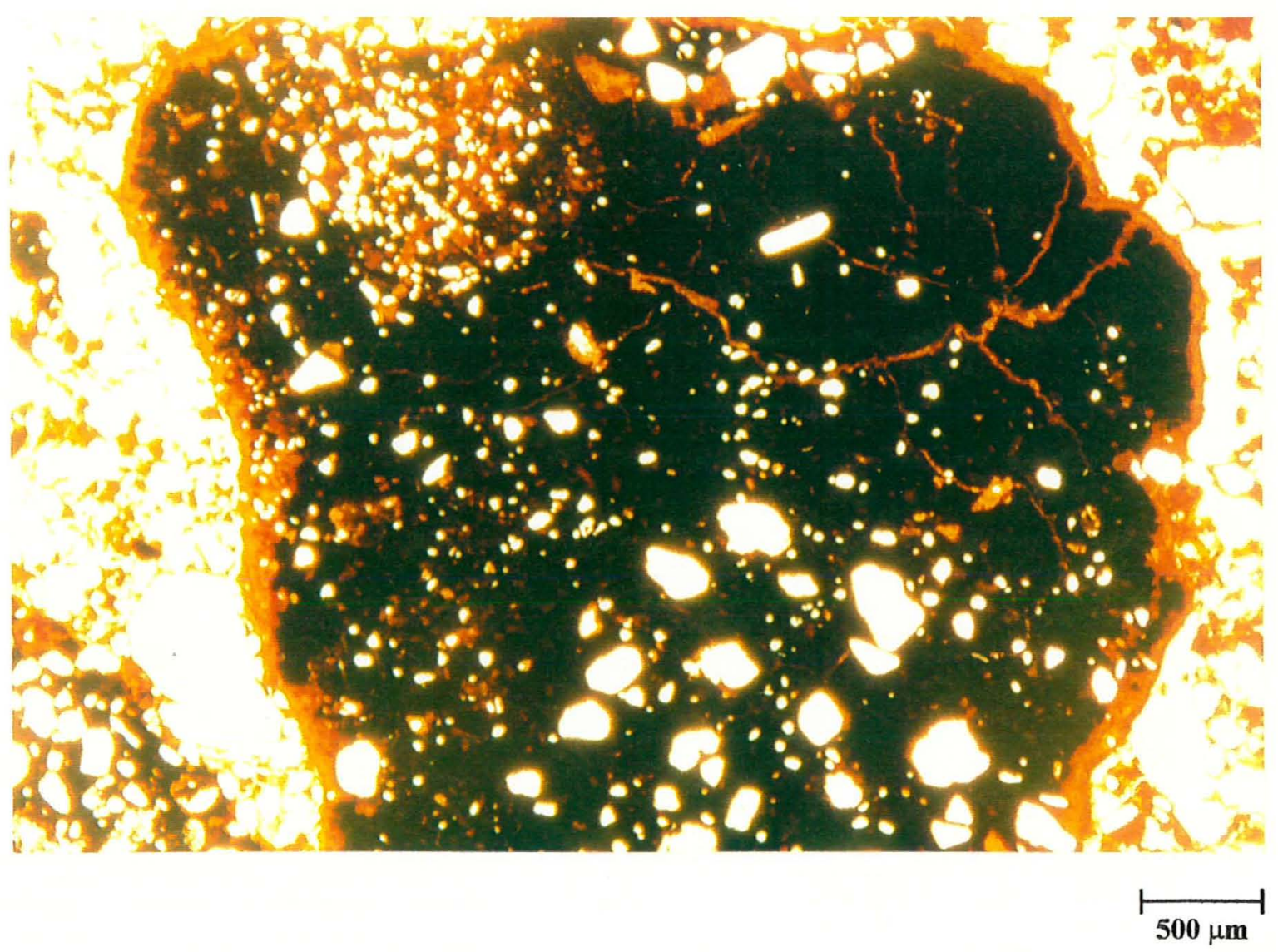

Figura 52. Pisolito de degradação no horizonte petroplíntico do perfil P2. Nota-se o desenvolvimento de um córtex goetítico com esqueleto fino (silte) que pode ser incorporado ao fundo matricial interglebular (LN-2,5x). 


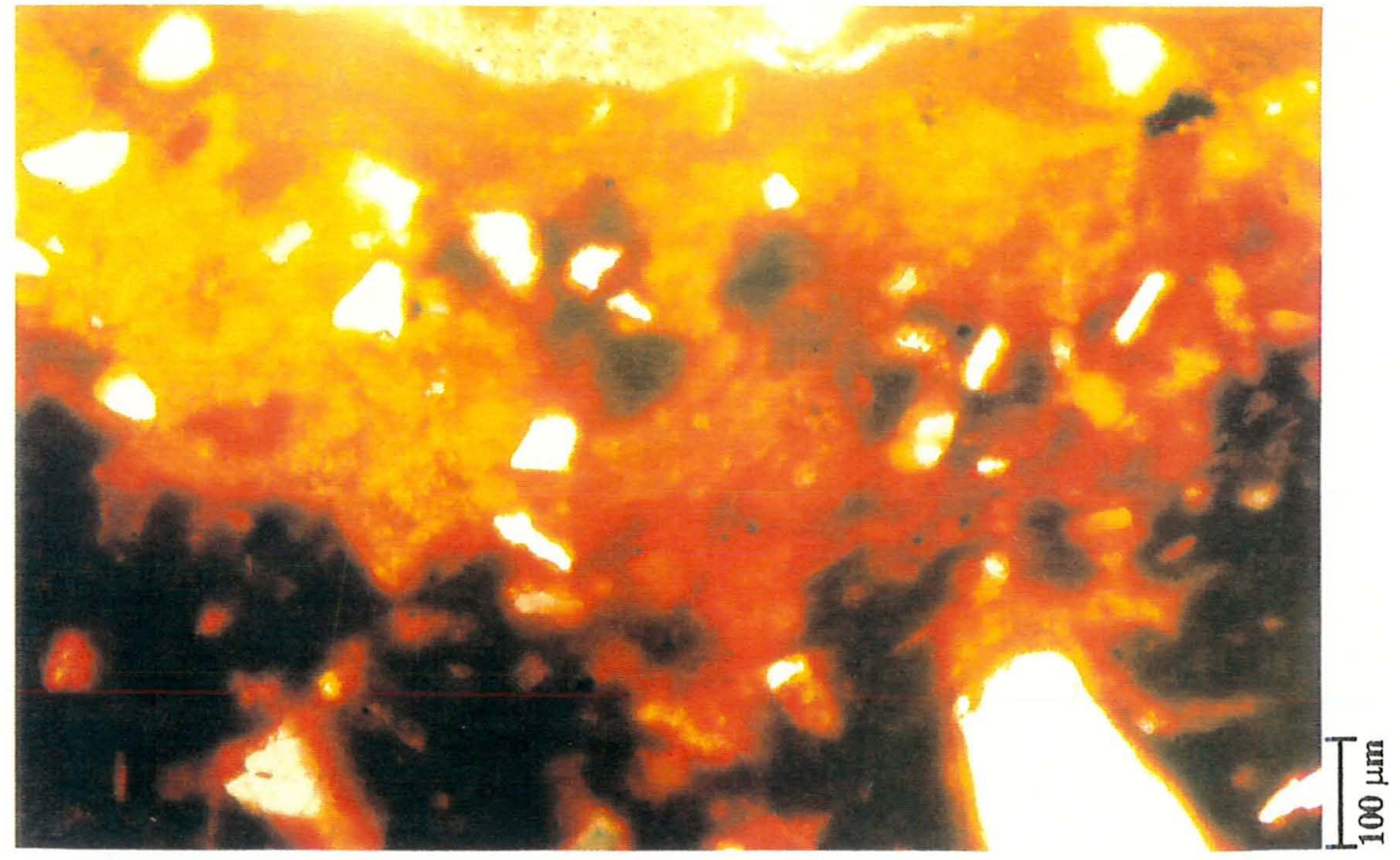

P2

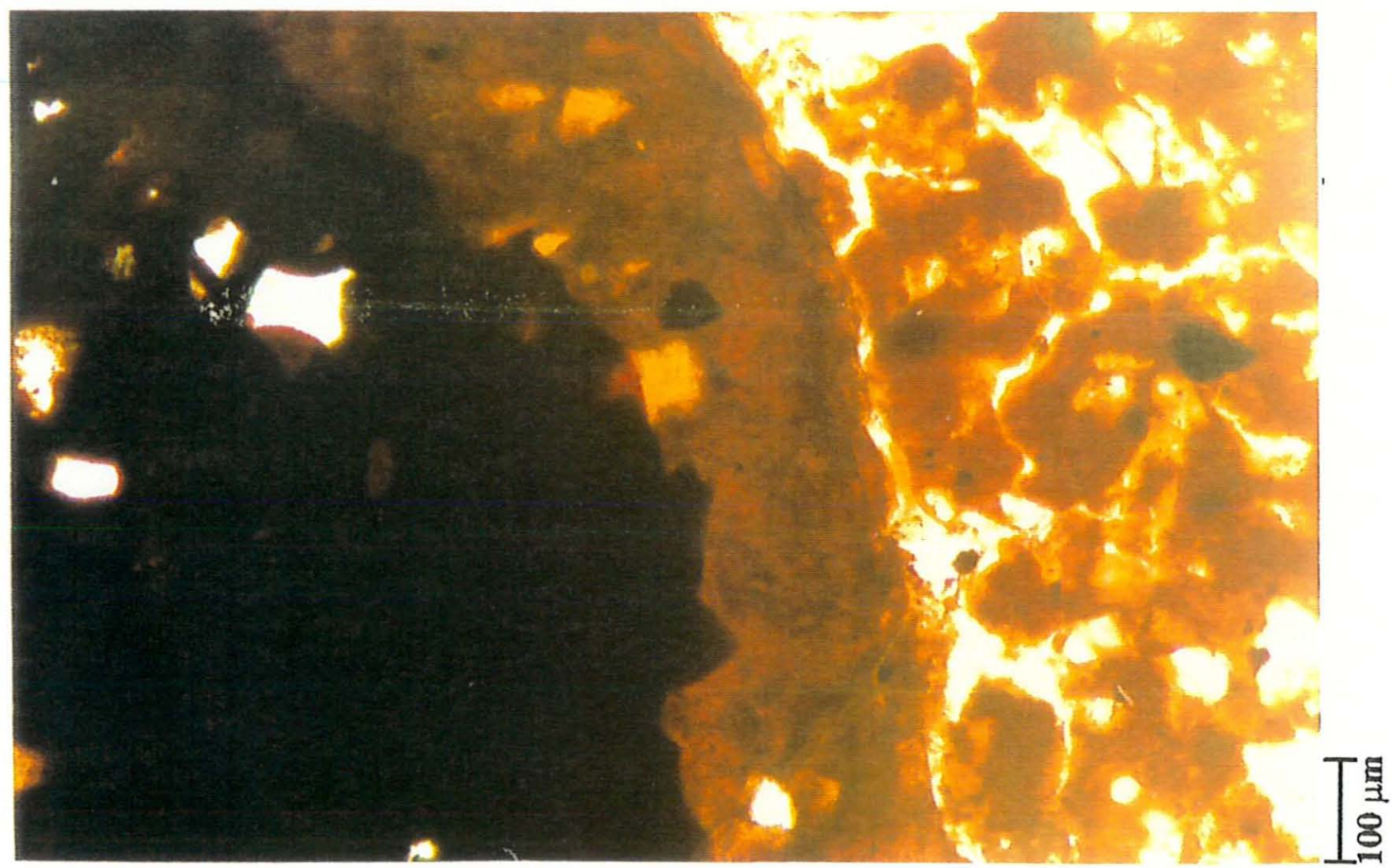

Figura 53. Detalhes do córtex goetítico evidenciando o estágio de degradação das glébulas, bem como a liberação do seu plasma e esqueleto na fração areia muito fina ao fundo matricial interglebular. Fotomicrografia das glébulas plínticas dos perfis P1 e P2 (LN - 10x). 


\subsubsection{Gênese das glébulas "ruiniformes"}

As glébulas identificadas aqui como "ruiniformes", correspondem as de maiores dimensões encontradas nos horizontes ferricretes e aparentemente assemelham-se a uma fusão de glébulas individuais. As evidências micromorfológicas confirmam essa suposição e sugerem a participação de aportes posteriores de ferro, difundindo-se e promovendo a cimentação das glébulas individuais, tal como sugerido por Sivarajasingham et al. (1962) e McFarlane (1976). A Figura 54 evidencia essas interpretações. Nota-se que a fusão entre as glébulas se dá por uma "ponte" de constituição diferente em relação ao fundo matricial intraglebular. Essa diferença é evidente no esqueleto, de dimensões superiores aos das glébulas. Isso sugere uma formação em diferentes épocas para as "pontes" e as glébulas, pois caso fossem sincrônicas, assemelhariam-se na granulometria do esqueleto. As fotos da Figura 54 correspondem a mesma glébula ruiniforme do horizonte petroplíntico (perfil P2), sendo que todos os pontos de fusão ("pontes") interglebulares observados no plano da lâmina mostram a mesma morfologia, ou seja, quartzo de granulometria diferente ao do fundo matricial intraglebular.

O fundo matricial na matriz friável entre essas glébulas é pouco poroso, compacto, mostrando apenas algumas ortocavidades (menos que 10\%). Muitos domínios são isóticos, evidenciando a presença de hematãs e uma forte segregação do ferro. Possivelmente constituem-se em ambientes mais confinados, e portanto, mais preservados dos processos de intemperismo, onde as mobilizações no seu interior são menos influenciadas ou mesmo, pouco influenciam o horizonte petroplíntico como um todo. Essas glébulas não mostram um córtex goetítico de degradação, no entanto, a presença freqüente de fraturas entre a "ponte" e as glébulas (Figura 54) sugerem que sua estrutura encontra-se em estágios iniciais de desmantelamento, liberando glébulas individuais ao horizonte petroplintico e retornando assim, as condições iniciais de formação. 

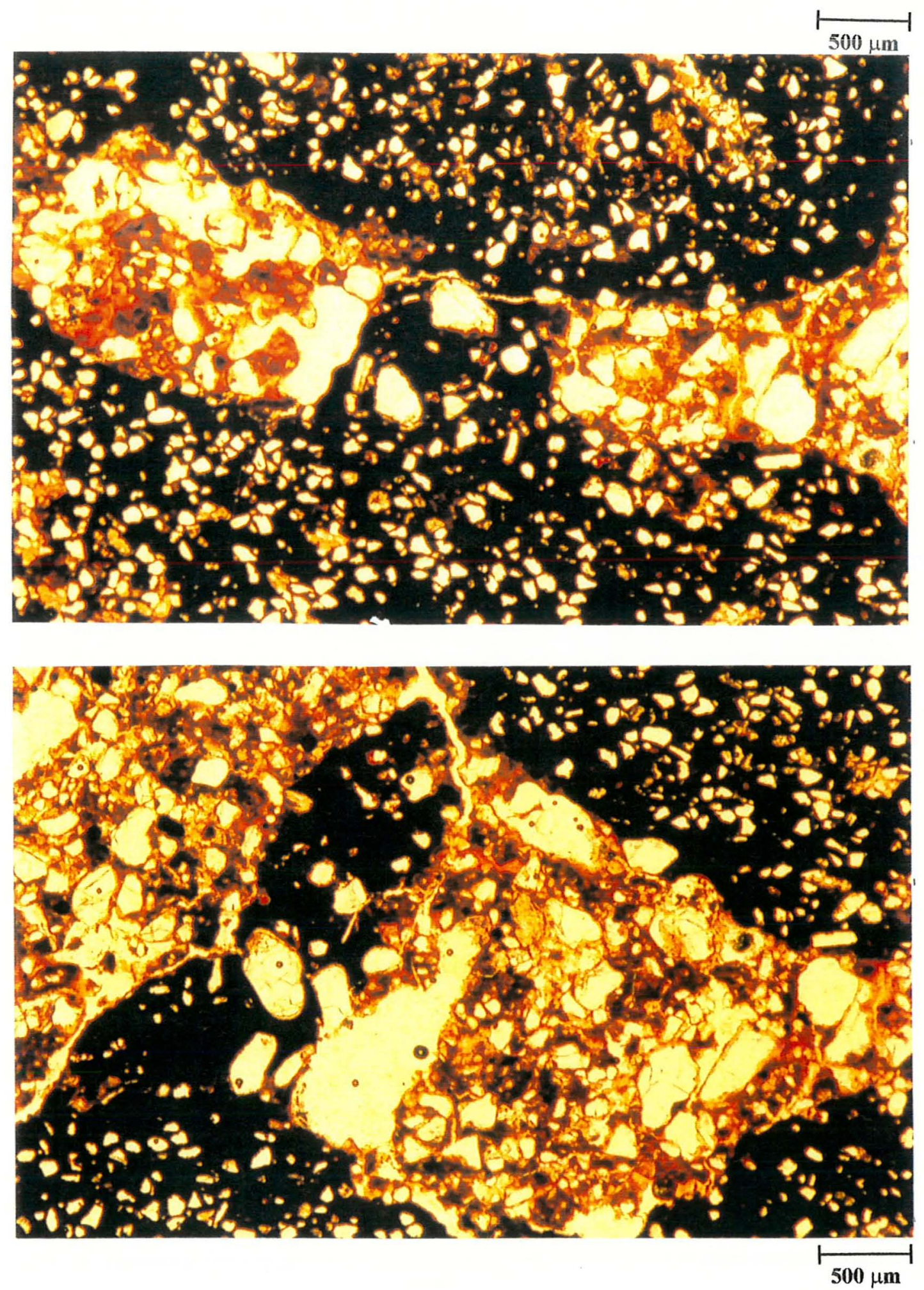

Figura 54. Fotomicrografia mostrando a gênese das glébulas "ruiniformes". Nota-se uma "ponte" entre as glébulas, promovendo sua fusão. A diferença de granulometria do esqueleto entre o fundo matricial intraglebular e a "ponte" sugere aportes de ferro posteriores à formação das glébulas $(\mathrm{LN}-2,5 \mathrm{x})$. 


\subsection{Evidências submicroscópicas: microscopia de varredura e microanálise}

As amostras indeformadas das glébulas plínticas e petroplínticas foram analisadas em microscópico eletrônico de varredura e microssonda. Essas observações possibilitaram complementar a caracterização mineralógica desses materiais, bem como elucidar alguns dos mecanismos envolvidos na sua gênese.

Dentre os minerais e elementos identificados nas glébulas plínticas e petroplínticas com as diferentes análises realizadas, a microscopia eletrônica e a microanálise possibilitaram a identificação de feldspatos potássicos e sódicos, cerianita, ilmenita, manganês e cobalto como constituintes dessas glébulas. Dentre eles, feldspatos potássicos são os mais comuns e mostram-se em diferentes estágios de intemperismo, predominando os fortemente intemperizados. A Figura 55 mostra em detalhes o mineral se decompondo. Duas interpretações podemos inferir desta figura: a primeira refere-se ao desenvolvimento de cavidades de dissolução, as quais podem ser preenchidas por outros materiais na evolução das glébulas; a segunda elucida o desenvolvimento de alguns minerais gibbsíticos no interior dos nódulos. Nota-se a presença da gibbsita acima e nas extremidades do feldspato, sugerindo uma origem autigênica, proveniente da degradação direta do mineral feldspático. Outros autores identificaram a ocorrência de gibbsita bem cristalinizada e de grande tamanho nas couraças ferruginosas (Tardy, 1993 e Tardy \& Novikoff, 1988), tal como mostrado na Figura 55.

Minerais primários, tais como feldspato e mica, foram indicados por muitos autores como constituintes comuns de nódulos e concreções ferruginosas (Beauvais \& Roquin, 1996; Debaveye et al., 1987; Ibanga, 1980; Leprun, 1981; Muller \& Bocquier, 1986; Schwertmann \& Fanning, 1976 e Sidhu et al., 1977). McFarlane (1976) afirma que os nódulos provenientes da oscilação do lençol tem a habilidade de fossilizar internamente o estado de intemperismo do saprolito, possibilitando assim, a manutenção de minerais primários no seu interior. Portanto, a presença constante desses minerais no interior das glébulas petroplínticas aqui estudadas confirmam sua formação nos horizontes saprolíticos, bem como sugerem a participação do lençol freático na gênese desses materiais. 

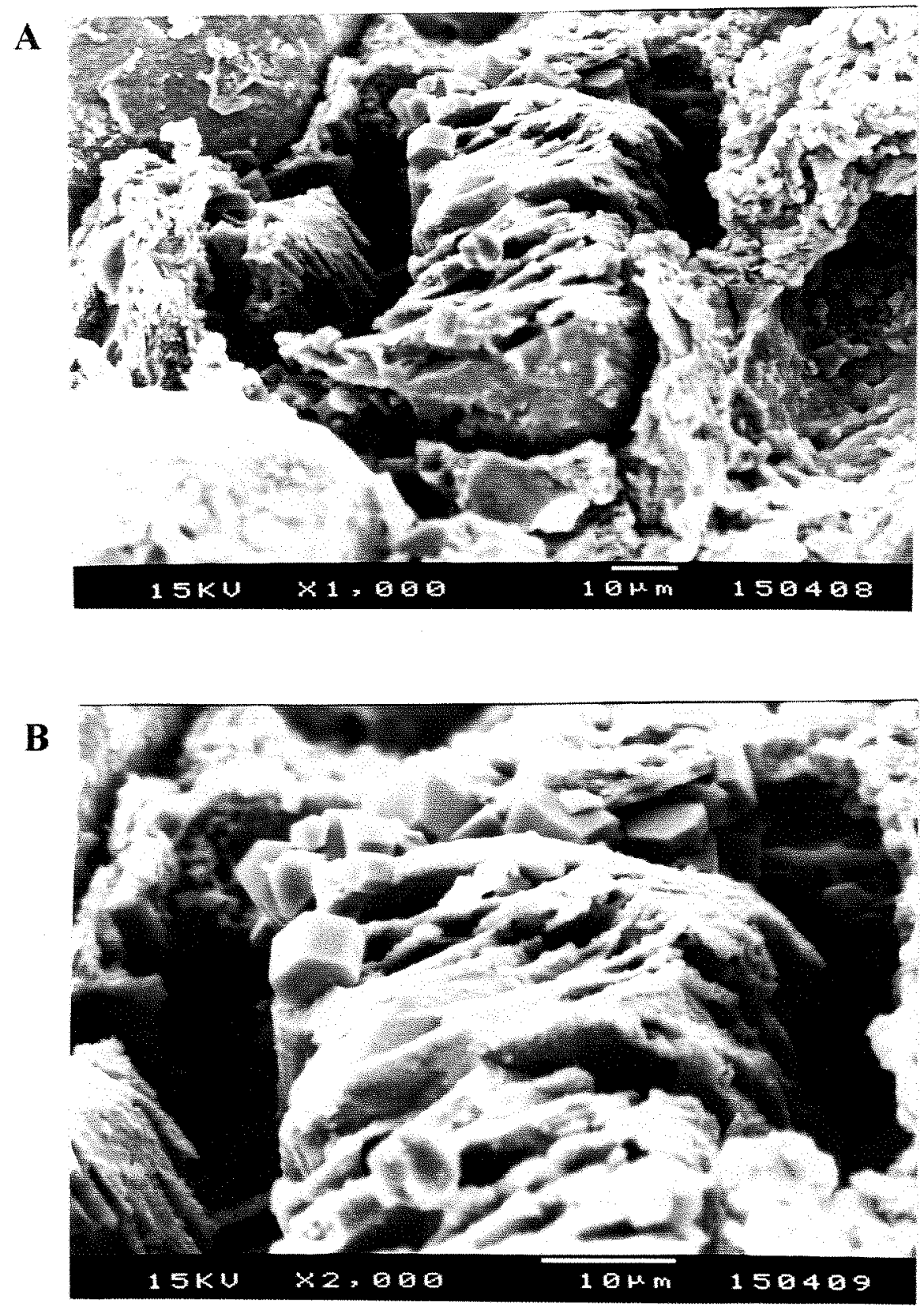

Figura 55. Feldspato e gibbsita no interior de uma glébula petroplíntica (perfil P2). Notase o estado de dissolução do feldspato, bem como a origem autigênica da gibbsita (Foto A - 1000x; Foto B - 2.000x). 
A presença de cerianita não é comum nas glébulas estudadas. Sua ocorrência aparece como um fenômeno local e sempre associada aos elementos cobalto e manganês. Outros autores também identificaram essa mesma correlação entre os elementos e evidenciaram a segregação de minerais raros (cerianita) durante a ferruginização na gênese dos ferricretes (Beauvais \& Colin, 1993; Beauvais e Roquin, 1996; Beauvais et al., 1990; Roquin, 1990 e Taylor, 1968). A Figura 56 mostra esses diferentes minerais e elementos, os quais são constituintes das glébulas com maior conteúdo de manganês, e portanto, são poucos expressivos na área estudada. Essas glébulas localizam-se na base do horizonte petroplíntico do P2.

A fim de entender o comportamento do $\mathrm{Ce}$ sob diferentes condições de redox, podemos comparar Ce, Fe e Mn. Para isso, o diagrama Eh-pH (Figura 57) também permite uma explicação para os diferentes mecanismos envolvidos na gênese das glébulas mais manganiferas. Nota-se pelo diagrama que a baixos valores de Eh (ponto A), os três elementos encontram-se na forma reduzida. A medida que o ambiente torna-se mais oxidante (ponto B), goetita é o primeiro mineral precipitado e representa os minerais de óxidos e hidróxidos de ferro componentes dos nódulos estudados. Nessas condições a atividade do $\mathrm{Fe}^{2+}$ decresce ao passo que a atividade do $\mathrm{Ce}^{3+}$ e $\mathrm{Mn}^{2+}$ permanecem inalteradas.

A precipitação da goetita ocorre principalmente nas paredes dos macroporos fissurais e canais localizados no saprolito e imediatamente abaixo do horizonte ferricrete, onde maiores potenciais oxidantes prevalecem. A medida que o lençol freático é progressivamente rebaixado, os valores de Eh (ponto B) favorecem a mobilização de manganês dos locais mais elevados da paisagem e deposição abaixo do horizonte petroplíntico e nos macroporos fissurais e canais, os quais sofreram a precipitação inicial de ferro. Os elementos $\mathrm{Ce}^{4+}$ e $\mathrm{Co}^{2+}$ acompanharam a mobilização e segregação dos óxidos e hidróxidos de manganês, devido a habilidade desses minerais em concentrar e controlar a distribuição de certos íons metálicos (Taylor \& MacKenzie, 1966).

O progressivo aumento dos valores de Eh durante o rebaixamento do lençol (ponto $\mathrm{C}$ ), favoreceu a precipitação do $\mathrm{Ce}^{3+}$ na forma de cerianita $\left(\mathrm{CeO}_{2}\right)$, originando os 
pequenos corpos de hábito glomerular, juntamente com o revestimento de $\mathrm{Mn}$, tal como

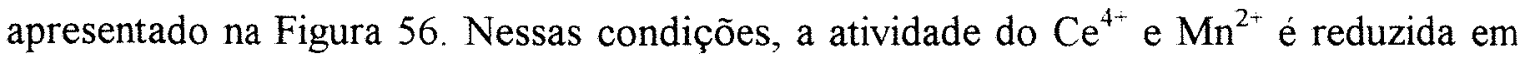
solução.

A composição química e mineral dos nódulos mais manganíferos, bem como os mecanismos pedogenéticos enunciados acima, estão de acordo com a estabilidade termodinâmica da cerianita, a qual precipita quando condições oxidantes prevalecem (Braun et al., 1990). Esse fato corrobora a suposição de que a gênese desses nódulos se deu sob condições mais oxidantes no perfil em relação àqueles essencialmente ferruginosos e que predominam no horizonte ferricrete. Por isso, estão localizados na base do horizonte petroplíntico e podem ser considerados os mais jovens deste horizonte.

Caulinita é único mineral silicatado presente em proporções consideráveis dentro das "lateritas" (Alexander \& Cady, 1962) e freqüentemente mostra uma história complexa (Schellmann, 1994) caracterizada por dissoluções e neoformação durante o desenvolvimento dos perfis "lateríticos"(Ambrosi et al., 1986; Muller \& Bocquier, 1986 e Nahon, 1991). Basicamente esse mineral foi identificado no interior das glébulas aparentando dois tipos morfológicos distintos. O primeiro, mostrando macrocristais de caulinita individualizados (aproximadamente $10 \mu \mathrm{m}$ ), bem cristalinizados e orientados (Figura 58). Possivelmente essa orientação das argilas está associada à sua mobilização (argiluviação) e deposição durante a gênese dos ferricretes (caulinita de primeira geração). $\mathrm{O}$ segundo tipo, são cristais que aparentam uma menor cristalinidade devido à morfologia com bordas arredondadas, bem como mostram uma associação em forma de "sanfona" (Figura 59). São de menores dimensões $(5 \mu \mathrm{m})$ e estão associados as porções das glébulas visualmente identificadas como pequenos volumes esbranquiçados no seu interior. Possivelmente referem-se as dissoluções atuais e neoformação de caulinita (caulinita de segunda geração) nas porosidades geradas com a dissolução de outros minerais (quartzo e feldspato) ou da própria caulinita.

Os grãos de quartzo quando observados nas seções delgadas, foram os principais constituintes do esqueleto, bem como das glébulas, constituindo aproximadamente $60 \%$ a $70 \%$ de sua constituição mineralógica. Geralmente mostraram-se fortemente 
intemperizados, originando figuras típicas de dissolução na sua superficie (Chauvel et al., 1982; Flageoleet, 1981 e FitzPatrick, 1993), bem como poros, denominados de cavidades de dissolução (Muller e Bocquier, 1986; Muller et al., 1981; Nahon, 1976 e Nahon et al., 1977), os quais podem ser preenchidos por outros materiais que não óxidos de ferro (Leprun, 1981). As Figuras 60 e 61 evidenciam uma possível dissolução do mineral quartzoso e preenchimento da porosidade gerada com macrocristais de gibbsita. Resultados similares foram encontrados por Bourman et al. (1987), argumentando que a presença de gibbsita nessas cavidades é indício de condições extremamente intemperizadas, ambientes ácidos onde a drenagem livre pode promover uma intensa lixiviação dos solutos. Possivelmente essas condições ocorram em microssítios no interior das glébulas, favorecendo a mobilização de $\mathrm{Al}$ a curtas distâncias e deposição nas cavidades de dissolução na forma de gibbsita secundária, assim como a completa lixiviação da sílica, a qual irá compor a estrutura dos minerais cauliníticos principalmente na rocha do perfil P2. A fonte primária desses minerais possivelmente é a degradação dos feldspatos potássicos.

Nota-se que o grão de quartzo não foi totalmente dissolvido e ainda permanece no interior da cavidade (Figura 60). 

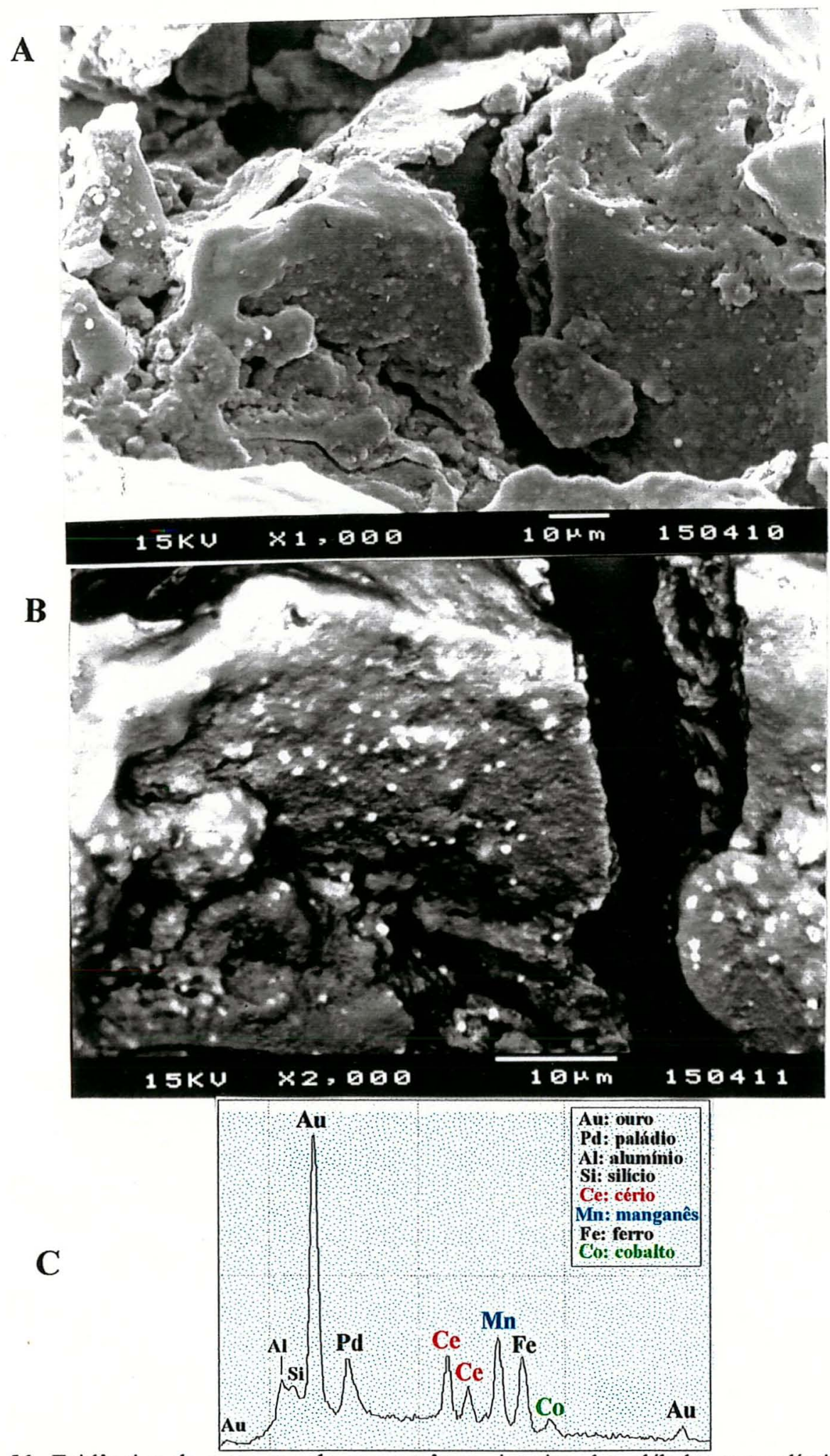

Figura 56. Evidências da presença de manganês no interior das glébulas petroplínticas com maior conteúdo do elemento no seu interior. Cobalto e cério estão associados devido a sua adsorção nos óxidos de Mn (McKenzie, 1989). Foto A: deposição de manganês associado com cério e cobalto formando uma película revestindo o grão de quartzo $(1.000 \mathrm{x})$. Foto B: cerianita (glomérulos arredondados e de coloração branca $-2.000 \mathrm{x}$ ). Figura $\mathrm{C}$ : análise semiquantitativa do "coating" de manganês e partículas de cerianita. 


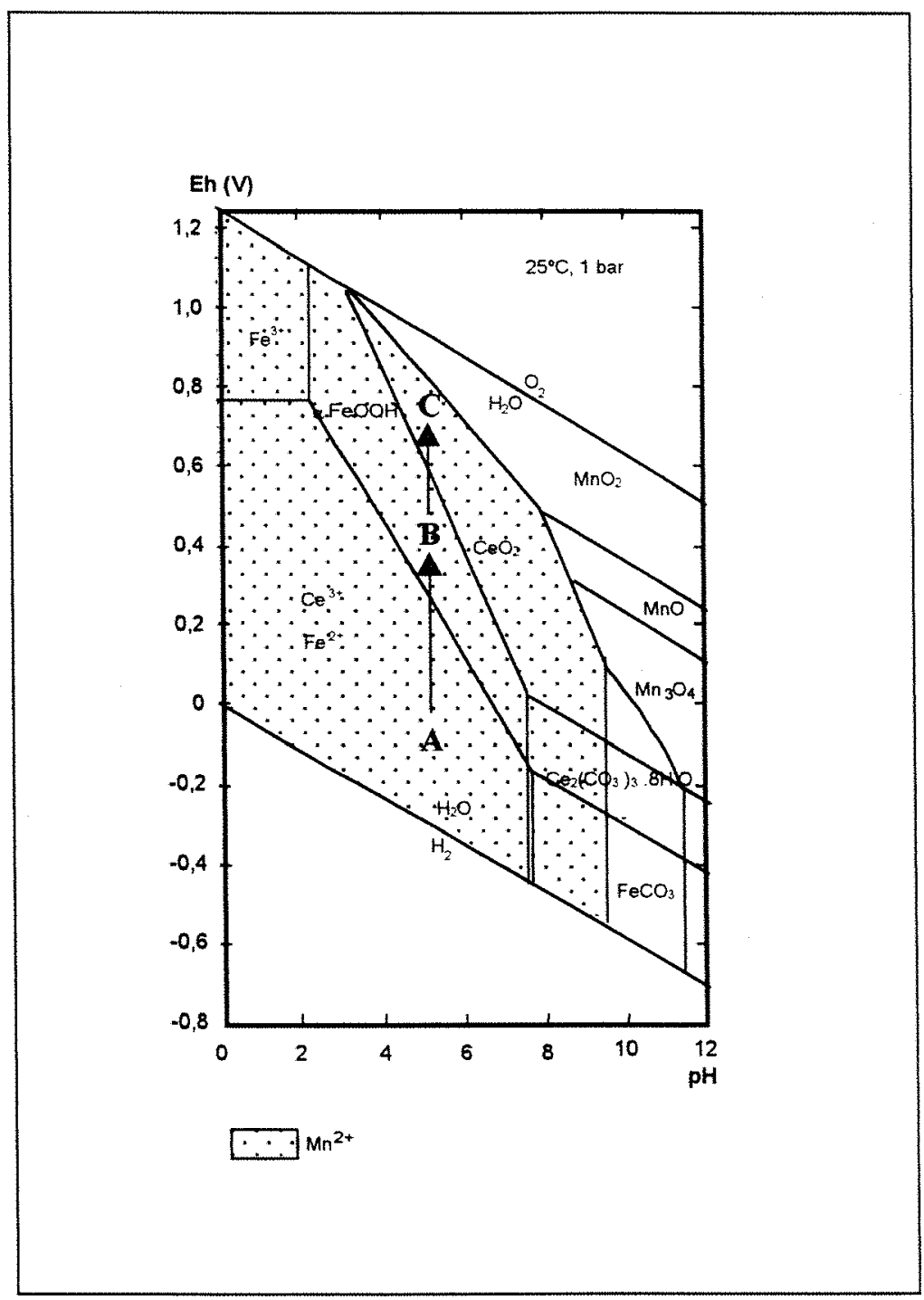

Figura 57. Campo de estabilidade da cerianita $\left(\mathrm{CeO}_{2}\right)$, Ce-Lanthanida $\left(\mathrm{Ce}_{2}\left(\mathrm{CO}_{3}\right)_{3} \cdot 8 \mathrm{H}_{2} \mathrm{O}\right)$, goetita $(\alpha \mathrm{FeOOH})$, siderita $\left(\mathrm{FeCO}_{3}\right), \mathrm{MnO}, \mathrm{MnO}_{2}, \mathrm{Mn}_{2} \mathrm{O}_{3}$ estimadas a partir da constante de equilíbrio $\log \mathrm{K}_{0}$. Adaptado de Braun et al. (1990) 


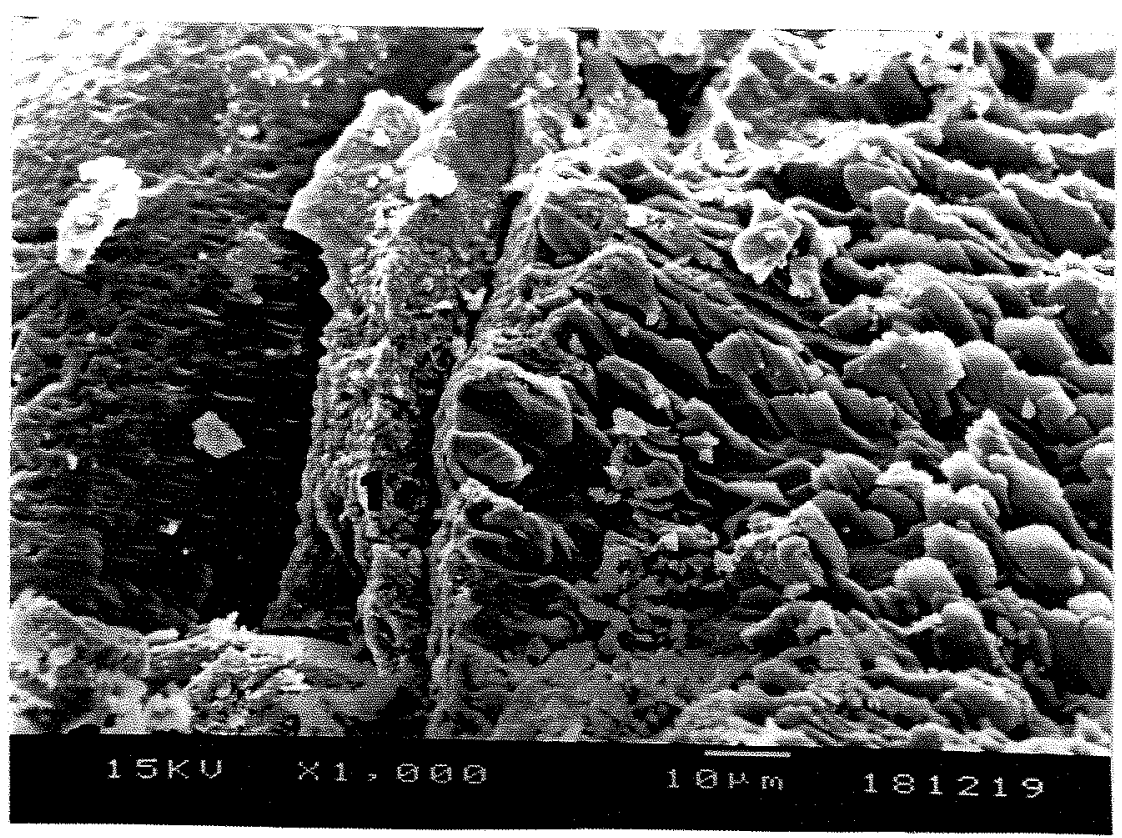

Figura 58. Plaquetas individuais de caulinita macrocristalina. Aparentemente há duas deposições ou camadas recobrindo o grão de quartzo. A primeira (1) é constituída predominantemente de ferro com menores conteúdos de caulinita; a segunda (2) mostra os macrocristais de caulinita orientados e bem cristalinizados aparentando mobilização e deposição na gênese das glébulas $(1.000 x)$.

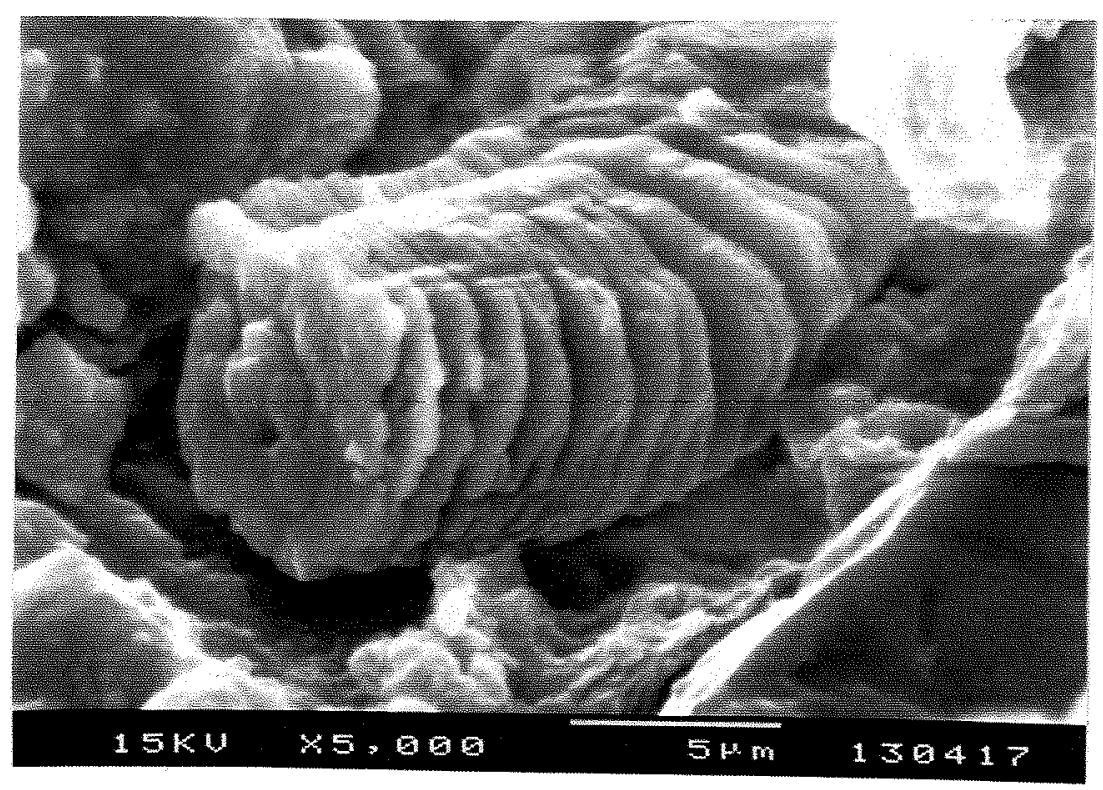

Figura 59. Plaquetas de caulinita em forma de sanfona. Nota-se as bordas arredondadas sugerindo o estágio incipiente de cristalinização $(5.000 \mathrm{x})$. 


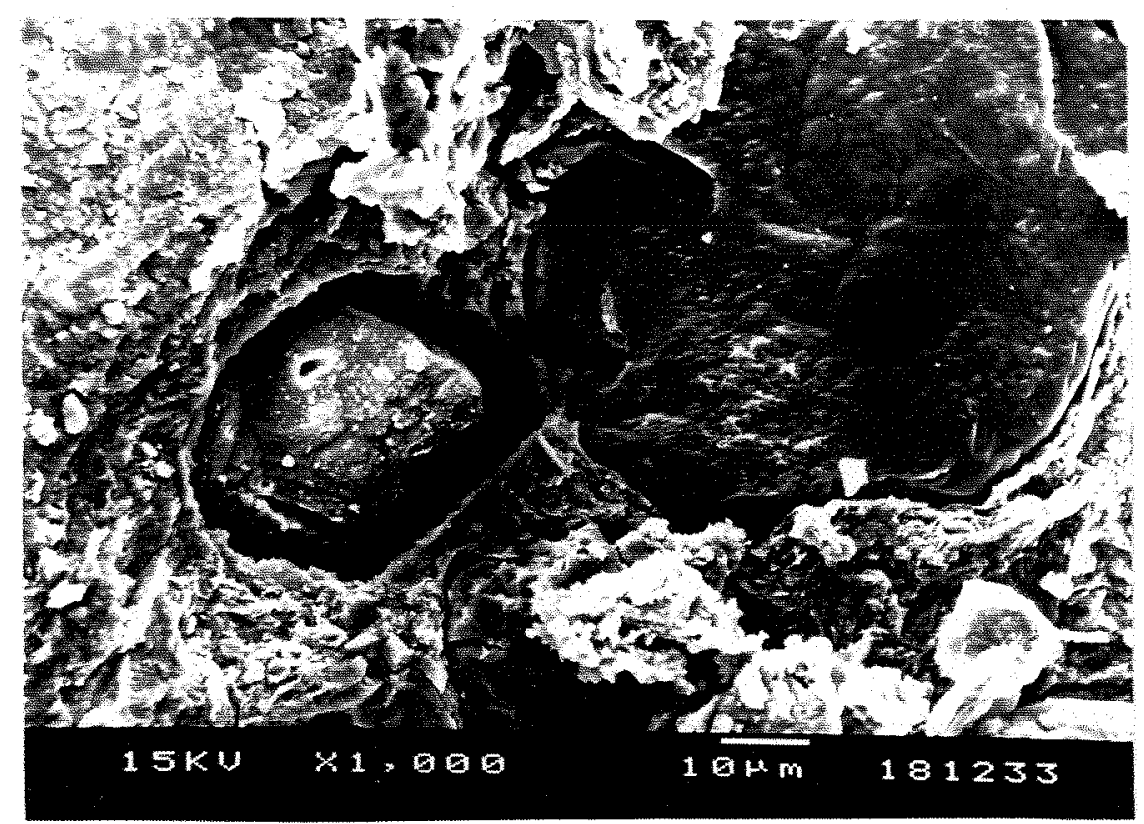

Figura 60. Cavidade de dissolução de quartzo. Nota-se que o mineral ainda permanece no seu interior $(1.000 \mathrm{x})$

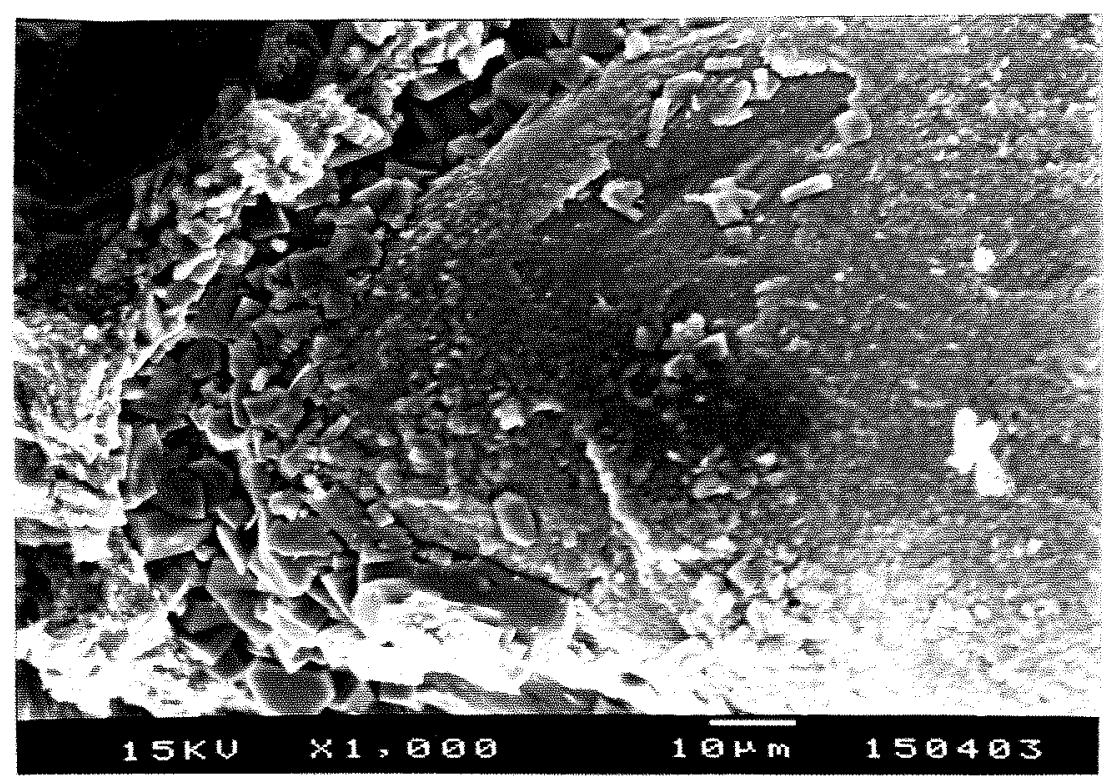

Figura 61. Gibbsita preenchendo a porosidade gerada na dissolução do grão de quartzo $(1.000 x)$ 


\subsection{Considerações finais: gênese dos ferricretes}

Os resultados e interpretações apresentados nos itens anteriores evidenciam que mecanismos fisicos e químicos de transferência de matéria são responsáveis pela gênese dos ferricretes na área estudada. Essas transferências não envolvem apenas a mobilização do ferro ferroso em solução e sua segregação nos horizontes saprolíticos no limite de oscilação do lençol freático, mas também, mecanismos pedogenéticos de lixiviação, eiluviação de argilas e compostos de ferro.

É proposto aqui que os materiais petroplinticos foram formados por deposição local de ferro no estreito limite de oscilação do lençol, tal como atualmente defendido por vários autores para esses materiais localizados nos baixos níveis topográficos (Bigarella et al., 1996; Bourman et al., 1987; Bourman, 1993; Goldbery \& Beyth, 1984; King et al., 1990; Pedro \& Melfi, 1982 e Wright et al., 1992). Supostamente, a paisagem nesse terço inferior da vertente sob domínio dos ferricretes seria dominada por solos podzólicos rasos $(\mathrm{A}+\mathrm{Bt} \sim 1 \mathrm{~m}$ de espessura) localizados em cotas superiores as que hoje se encontram. Nessas condições, a oscilação do lençol durante a segregação do ferro foi condicionada pela rocha abaixo, favorecendo a configuração lateral dos horizontes ferricretes tal como encontramos hoje na paisagem. A Figura 62 mostra em detalhes a distribuição atual dos diferentes horizontes na sequência estudada. É evidente a similaridade entre a configuração lateral da rocha e dos ferricretes. Nota-se também que o início dos sinais hidromorfismo (matizes com maior valor e baixo croma) nos horizontes saprolíticos distribui-se de maneira similar ao nível superior do lençol, verificado 3 dias após uma chuva. Isso sugere que a rocha exerceu e continua exercendo uma forte influência na oscilação do lençol, uma vez que ambos, sinais de hidromorfismo e nivel do lençol, acompanham a topografia de alteração da rocha. Essa configuração lateral dos horizontes ferricretes na seqüência estudada só pode ser explicada pela deposição de ferro no limite superior do lençol freático.

As condições iniciais de segregação do ferro na gênese dos ferricretes divergem em alguns aspectos em relação ao que encontramos hoje na paisagem. É de se supor que o nível do lençol freático oscilava na altura do limite superior do horizonte $\mathrm{F}$ como 
encontramos hoje na seqüencia estudada, dominado pelos horizontes saproliticos, bem como, os solos localizavam-se em cotas superiores que os atuais e em condições de melhor drenagem em relação aos horizontes abaixo. O perfil hoje identificado como $\mathrm{P} 1$, mostrava uma seqüência de horizontes $\mathrm{A}$ e $\mathrm{Bt}$ acima do saprolito, divergindo do restante da sequeencia estudada devido à sua menor espessura do horizonte textural. Condições semelhantes a este perfil estendia-se até as proximidades do perfil P2, onde também a rocha estava mais próximo à superficie. Nesses ambientes, o ferro mobilizado das porções a montante da paisagem foram depositados no limite superior do lençol freático, onde teve lugar a oxidação dos compostos ferrosos em férricos. Assim, o máximo de desenvolvimento dos ferricretes, representado pela maior espessura do horizonte $F$, foi condicionado pela proximidade à superficie do limite superior de oscilação do lençol, onde maiores potenciais de oxidação prevalecem em relação aos horizontes mais profundos e, possivelmente, foram os primeiros locais de formação da couraça nodular.

A deposição e segregação do ferro é antecedida e acompanhada por processos pedogenéticos e biológicos durante a evolução da paisagem. Esses mecanismos evoluíram em duas condições diferenciadas de potenciais de oxidação. Primeiro, sob condições de menor umidade durante parte do período seco, com o lençol retraído e confinado as porções mais próximas ao córrego, uma trama de canais e cavidades é gerada durante a saprolitização da rocha, tal como evidenciado atualmente na porção superior do horizonte $\mathrm{Cr}$ dos perfis estudados. A atividade biológica também é responsável pelo desenvolvimento de pedotúbulos e canais nos solos e saprolito. Alguns desses poros tornaram-se sítios de preenchimento, principalmente de argila iluviada dos horizontes superiores e algumas vezes acompanhada por grãos de quartzo na fração areia muito fina e silte. No entanto, caulinita neoformada durante saprolitização da rocha é outro material de preenchimento. Esses processos operam em condições de alguma umidade, porém o saprolitos e solos não se encontram saturados, de modo que a condição de umidade é necessária ao desenvolvimento dos processos pedogenéticos enunciados acima. 
Durante o período úmido e com a elevação do lençol freático, o ferro é lixiviado tanto das porções mais elevadas da paisagem como dos horizontes superiores, e depositados na superficie do lençol freático, precipitando hematita nos poros de menor tamanho, principalmente aqueles preenchidos com argila iluviada ou neoformada, bem como goetita nos macroporos. Assim, a distribuição da porosidade exerce um papel fundamental no tipo de óxidos ferro formado (Tardy \& Nahon, 1985), bem como estabelecem os sítios preferenciais de precipitação e segregação desses elementos nos horizontes saprolíticos. Géis de ferro também exercem um importante papel no preenchimento da porosidade, contribuindo para a morfologia das atuais petroplintitas.

Após ciclos sucessivos de umidecimento e secagem o ferro é cristalinizado nos períodos secos e segregado nos períodos úmidos nos locais de maior concentração do elemento, originando as feições ferruginosas identificadas como mosqueados. Segundo Tardy \& Nahon (1995) a porosidade é progressivamente reduzida com a deposição do ferro, favorecendo cada vez mais a precipitação do elemento nesses locais, principalmente na forma de hematita e nos poros de pequeno tamanho, supersaturados em ferro e com baixa atividade da água.

Os mosqueados são progressivamente individualizados a medida que mecanismos diferenciados de expansão e contração entre o próprio mosqueado e a matriz saprolítica favorecem o desenvolvimento de uma porosidade no contato entre essas diferentes estruturas. Associado a isso, a lixiviação do cimento ferruginoso durante os períodos úmidos, desestruturando a matriz e favorecendo a remoção da caulinita, completam a individualização dessas feições, cessando seu período de crescimento até evoluírem para os ferricretes petroplínticos, tal como verificamos hoje nos perfis. No entanto, a evolução dos mosqueados macios para petroplintita foi influenciado pela rebaixamento definitivo do lençol freático, possibilitando sua completa desidratação e oxidação dos compostos de ferro pouco cristalinos.

Do enunciado acima podemos sugerir que a ferruginização foi acompanhada com uma redução da paisagem e concentração de alguns elementos poucos móveis. $O$ maior conteúdo de titânio nas glébulas é a principal evidência dos processos geoquímicos 
envolvidos na lixiviação dos elementos móveis durante a redução dos perfis e concentração dos minerais resistentes ao intemperismo. A progressão desses mecanismos geoquimicos foram os principais responsáveis pela formação dos horizontes eluviais na paisagem e completa remoção do horizonte argílico do perfil P1 até as proximidades do P2, devido tanto à sua menor espessura original como à maior proximidade da rocha $\mathrm{e}$ umidade no solo, favorecendo a eluviação das argilas, bem como a lixiviação do ferro ferroso. Assim, os fenômenos de transferência de matéria e a "ferricretização" foram contemporâneos na evolução da paisagem. $O$ primeiro forneceu argila para $o$ preenchimento parcial dos macroporos no horizonte saprolítico, e o segundo, é responsável pela segregação e precipitação do ferro nesses locais, seja por difusão, seja na forma de géis, preenchendo a macroporosidade e originando as glébulas petroplínticas, tal como encontramos hoje na paisagem.

Ainda, podemos considerar outros mecanismos envolvidos na gênese do solum acima do ferricrete, sugerindo uma origem poligenética para esses materiais. A degradação do ferricrete é responsável pela liberação de plasma e esqueleto, tal como verificado nas observações micromorfológicas, os quais contribuíram para a matriz interglebular e desenvolvimento do solo acima. Essa degradação faz com que o horizonte petroplíntico esteja em constante mudança de posição no perfil, aprofundando-se e com tendência a desaparecer com o tempo, caso as condições edafoclimáticas atuais permaneçam inalteradas. Observando-se a Figura 62 fica evidente um "desbaste" das extremidades do horizonte ferricrete. A medida que se caminha para essas extremidades, as glébulas tornam-se menores e esparsas na matriz do solo, sugerindo que parte deste é originado pela degradação do ferricrete.

Associado aos processos de degradação do ferricrete e evolução geoquímica na gênese do solum, uma origem também coluvionar para os horizontes superficiais nos perfis estudados, complementam as etapas de evolução pedogenética desta porção da paisagem. Esse processo é mais efetivo para todos os horizontes do perfil P3.

A formação dos horizontes plínticos sucedem o completo desenvolvimento das petroplintitas e rebaixamento do lençol, favorecendo condições físico-químicas 
adequadas à segregação do ferro no horizonte saprolítico imediatamente abaixo do ferricrete petroplíntico. Desta vez, a fonte de ferro é proveniente do desmantelamento da couraça devido ao estabelecimento de uma hidromorfia "suspensa", propiciando assim a disponibilização e mobilização do $\mathrm{Fe}^{2+}$ da matriz interglebular para os horizontes inferiores. Assim, a gênese dos horizontes plínticos é marcada pelos maiores conteúdos de ferro e menores potenciais de oxidação em relação às condições de formação do horizonte petroplíntico acima, possibilitando a ferruginização do saprolito, os quais evoluem para as atuais plintitas com os sucessivos aportes de ferro e ciclos de umidecimento e secagem, até promoverem uma parcial obliteração das estruturas da rocha.

Atualmente, as condições são favoráveis à segregação do ferro nos horizontes $\mathrm{Cr}$ dos perfis P1 e P2. No entanto, os mosqueados do perfil P3 aparentam um pequeno grau de desenvolvimento, fato que, associado ao desmonte das estruturas porfiricas fechadas, transformando-as em gefúricas, sugerem que a ferruginização é pouco significativa e está sendo "apagada" pelos outros processos pedogenéticos envolvidos na remoção de ferro e argila no desenvolvimento do perfil. Esse fato, associado a atual degradação dos ferricretes, leva-nos a acreditar que as condições atuais divergem daquelas responsáveis pela gênese dos ferricretes no passado. Pode-se atribuir essas diferenças a dois possiveis fatores associados ao clima e a litologia da formação Adamantina. Inicialmente, podemos sugerir que os horizontes petroplínticos tiveram sua origem em climas pretéritos, em condições paleoclimáticas mais contrastantes que as atuais, provavelmente mais quentes, com estações bem definidas e um período seco prolongado, fatores esses fortemente apregoados por muitos autores como uma condição sine qua non na evolução das couraças ferruginosas (Alexander \& Cady, Sivarajasingham et al., 1962 e Tardy et al., 1991). Outra possível diferença em relação às condições atuais, pode-se atribuir a litologia. Possivelmente, o arenito Adamantina teria níveis com maiores conteúdos de ferro (lamito?), os quais teriam-se alterado completamente nas cotas mais elevadas da paisagem, fornecendo ferro para os atuais ferricretes petroplínticos. 


\section{$\underline{L E G E N D A}$}

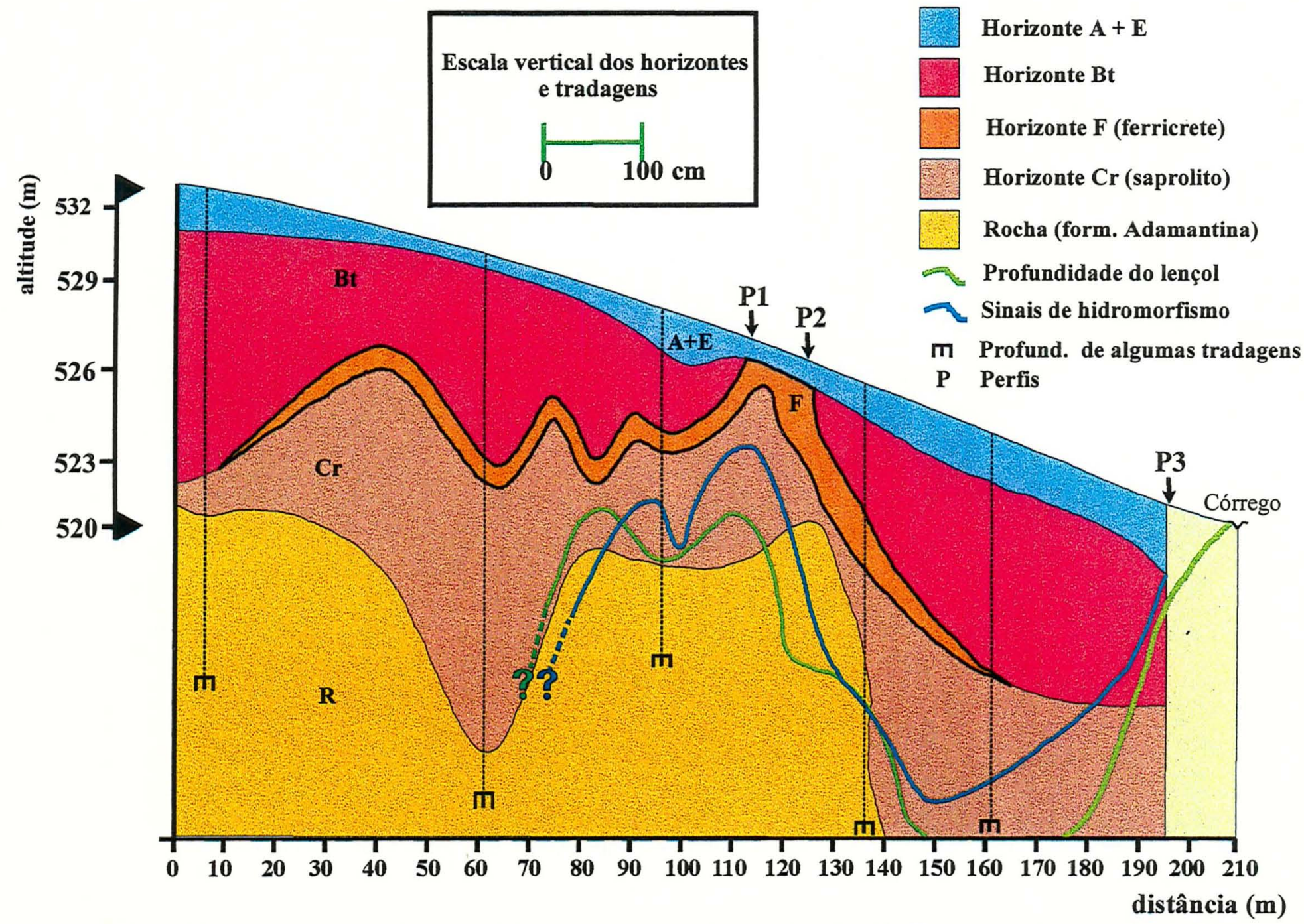

Figura 62. Configuração lateral e vertical dos horizontes na seqüência estudada. Há três escalas no desenho: a) escala horizontal (x);

b) escala vertical $\left(x^{*} 2\right)$ e c) escala dos horizontes $\left(x^{*} 20\right)$. Assim, há um exagero vertical tanto na representação dos horizontes como na escala vertical da figura. 


\section{CONCLUSÕES}

1) Foram três as feições ferruginosas identificadas na área estudada.: petroplintita, plintita e mosqueados. As glébulas petroplínticas mostraram os maiores conteúdos de $\mathrm{Fe}$ total no perfil $(\mathrm{Fe}=272 \mathrm{~g} / \mathrm{Kg})$, seguidas pelas plínticas $(156,92 \mathrm{~g} / \mathrm{Kg})$. Enquanto as primeiras são compostas essencialmente por óxidos de Fe bem cristalinizados, as plintitas tem maiores teores de óxidos de Fe de baixa cristalinidade.

2) Caulinita, hematita, goetita, mica, gibbsita e anatásio são os principais constituintes mineralógicos da fração argila dos ferricretes. Mineralogia idêntica às glébulas foram observados em todos os horizontes dos perfis estudados. A fração areia e silte é dominada por quartzo, no entanto, feldspato potássico foi encontrado em diferentes estágios de intemperismo, predominando os fortemente intemperizados. A presença constante desses minerais potássicos no interior das glébulas é a principal evidência da origem das petroplintitas associada à ferruginização dos horizontes saprolíticos. Também, outros minerais como feldspato sódico, ilmenita e cerianita são componentes dos ferricretes, embora menos expressivos.

3) O elemento do grupo das terras raras, cério ( $\mathrm{Ce}$ ), apareceu como precipitados concentrados (cerianita) e sempre associado ao manganês e cobalto no cerne das glébulas, enegrecidas devido à presença do manganês;

4) As glébulas petroplínticas atualmente estão se degradando e liberaram ferro para a formação das plintitas sotopostas, assim como plasma e esqueleto fino para o fundo matricial interglebular.

5) A ausência de um perfil de intemperismo típico, destituído de uma zona pálida, bem como a pequena participação de goetita aluminosa nas glébulas petroplínticas, sugerem uma origem alóctone do ferro na gênese dos horizontes petroplínticos. A 
presença dos ferricretes apenas no sopé da vertente é a principal evidência da lixiviação e mobilização do ferro das paisagens à montante e deposição no estreito limite de oscilação do lençol freático;

6) Os ferricretes petroplínticos foram formados no limite superior de oscilação do lençol freático onde condições mais oxidantes prevalecem. A atual configuração lateral dos horizontes na seqüência estudada comprova a designação de ferricretes de lençol a esses materiais e evidenciam a influência da rocha durante a segregação do ferro, através do controle do nivel de oscilação do lençol freático;

7) Micromorfologicamente, as glébulas mostram-se divergentes quanto a distribuição do esqueleto e plasma. Algumas são predominantemente dominadas por esqueleto na fração areia muito fina, enquanto outras predomina a fração média. Ainda existem as glébulas onde o esqueleto não se encontra triado, variando em granulometria. A grande maioria mostra uma fábrica interna dominada por volumes de plasma apenas. Fatores pedo-lito-biológicos estão envolvidos nessa diversidade entre glébulas num mesmo horizonte e muitas vezes podem ser erroneamente interpretadas como de origem alóctone.

8) As maiores glébulas dos horizontes saproliticos, aqui identificados como "ruiniformes", assemelham-se a uma fusão de glébulas menores. Evidências micromorfológicas confirmaram essa impressão, bem como elucidaram sua gênese. Aportes de ferro posteriores à formação das petroplintitas possivelmente foram responsáveis pela fusão de glébulas menores através de uma "ponte" ferruginosa interglebular.

9) A acumulação de ferro nos horizontes saprolíticos durante a gênese das petroplintitas foi inicialmente na forma de mosqueados, os quais evoluíram para as formas atuais após ciclos sucessivos de umidecimento e secagem. No entanto, atualmente as condições pedoambientais são desfavoráveis à gênese de ferricretes neste perfil, uma vez que a acumulação do ferro "em massa" está sendo obliterada. Isso significa que os processos pedogenéticos de remoção de argila e ferro estão se sobrepondo à ferruginização e manutenção das estruturas porfiricas fechadas, necessárias ao 
estabelecimento de condições fisico-químicas adequadas à segregação do ferro. Portanto, os mecanismos atuais de mosqueamento assemelham-se aos desenvolvidos na gênese das petroplintitas, diferindo apenas na intensidade da ferruginização. Fatores litológicos ou climáticos podem ser responsáveis pela formação pretérita da petroplintita, os quais não se processam nas paisagens atuais.

10) Processos de e-iluviação de argilas, destruição de argilas por hidromorfismo temporário no topo do $\mathrm{Bt}$, colúvios e a degradação dos horizontes petroplínticos contribuem para complexa gênese do solum sobreposto ao horizonte ferricrete. 


\section{REFERÊNCIAS BIBLIOGRÁFICAS}

ALEVA, G.J.J. Laterites. Concepts, geology, morphology and chemistry. Wageningen: ISRIC, 1994. 169p.

ALEXANDER, T.L.; CADY, J.G. Genesis and hardening of laterite in soils. Washington, D.C.: Soil Conservation Service. United States Department of Agriculture, 1962. 90p. (Technical Bulletin, n.1282).

ALEXANDRE, J. Structure et site topographique originels des cuirasses latéritiques. Bulettin de la Société géographique de Liège, v.27, p.125-137, 1991.

AMBROSI, J.P.; NAHON, D. Petrological and geochemical differentiation of lateritic iron crust profiles. Chemical Geology, v. 57, p.371-393, 1986.

AMBROSI, J.P.; NAHON,D.; HERBILLON, A.J. The epigenetic replacement of kaolinite by hematite in laterite - petrographic evidence and the mechanisms involved. Geoderma, v.37, n.4, p.283-294, Aug. 1986.

ANAND, R.R. \& GILKES, R.J. Iron oxides in lateritic soils from Wertern Australia. Journal of Soil Science, v.38, n.4, p.607-622, Dec. 1987a.

ANAND, R.R.; GILKES, R.J. Variations in the properties of iron oxides within individual specimens of lateritic duricrust. Australian Journal of Soil Research, v.25, n.3, p.287-302, 1987 b.

ANJOS, L.H.C. dos; FRANZMEIR, D.P.; SCHULZE, D.G. Formation of soils with plinthite on a toposequence in Maranhão State, Brazil. Geoderma, v.64, p.257-279, 1995.

BARDOSSY, G.Y. Paleoenvironments of laterites and lateritic bauxites-effect of global tectonism on bauxite formation. In: INTERNATIONAL SEMINAR LATERITISATION PROCESSES, Trivandrum, 1979. Proceedings. Rotterdam: Oxford \& IBH Publ. Co., 1981. p.1-10. 
BARRAL SILVA, M.T. Estudio de las separaciones de hierro y manganeso en suelos y sedimentos de Galicia. Santiago, 1987. 680p. Tesis (Ph.D.) - Facultad de Biología de la Universidad de Santiago de Compostela.

BARRAL SILVA, M.T.; TABOADA CASTRO, M.T.; GUITIAN OJEA, F. Caracterización quimica y mineralogica de las formas de hierro en suelos sobre substrato calizo de Galicia (nw de España). Anales de Edafologia y Agrobiologia, $t$. XIVII, n. 1-2, p.1303-1321, 1988.

BATISTA, M. de A; SANTOS, M.C. Morfologia e gênese de dois solos com plintita da Região Meio-Norte do Brasil. Revista Brasileira de Ciência do Solo, 19:, n.2, p.287-296, maio/ago. 1995.

BEAUVAIS, A.; BOEGLIN, J.L., COLIN, F. MAZALTARIM, D; MULLER, J.C. Geochemical evolution and degeneration of ferricretes under a humid tropical climate in the east of Central African Republic. Chemical Geology. Geochemistry of the earth's surface and of mineral formation. v.84, p.25-26, July, 1990. Special Issue.

BEAUVAIS, A.; COLIN, F. Formation and transformation processes of iron duricrust systems in tropical humid environment. Chemical Geology, v.106, p.77-101, 1993.

BEAUVAIS, A.; ROQUIN, C. Petrological differentiation patterns and geomorphic distribuition of ferricretes in Central Africa. Geoderma, v.73, n.1-2, p.63-82, Sept. 1996.

BEAUVAIS, A.; TARDY, Y. Degradation and dismantling of iron crusts under climatic changes in Central Africa. Chemical Geology, v.107, p.277-280, 1993.

BEAUVAIS, A.; TARDY, Y. Formation et dégradation des cuirasses ferrugineuses sous climat tropical humide, a la lisière de la forêt équatoriale. C. R. Acad. Sci. Paris, v.313, série II, p.1539-1545, 1991.

BELLINFANTE, N.; PANEQUE, G.; CLEMENTE, L. Estudio de las concreciones de un suelo de perfil complejo situado en la terraza del Guadalquivir de San Pablo (Sevilla). Anales de Edafologia y Agrobiologia, v.29, p.477-483, 1970.

BIGARELLA, J. J.; BECKER, R. D; PASSOS, E. Estrutura o origem das paisagens tropicais e subtropicais: Intemperismo biológico, pedogênese, laterização, bauxitização e concentração de bens minerais. Florianópolis: DAUFSC, 1996. 2v. 
BILONG, P.; BELINGA, S.E.; VOLKOFF, B. Séquence d'évolution des paysages cuirassés et des sols ferrallitiques en zones forestières tropicales d'Afrique centrale. Place des sols ’a horizons d'argile tachetée. C.R.Acad.Sci.Paris, v.314, Sériell, p.109-115, 1992.

BLUME, H.P. ; SCHWERTMANN, U. Genetic evaluation of distribuition of aluminium, iron, and manganese oxides. Soil Science Society of America Proceedings, v. 33, n.3, p. 438-444, may/june, 1969.

BOCQUIER, B; BOULANGE, B.; ILDEFONSE, P.; NAHON, D.; MULLER, D. Transfers, accumulation modes, mineralogical transformations and complexity of historical development in lateritic profiles. In: II INTERNATIONAL SEMINAR ON LATERITISATION PROCESSES, São Paulo, 1982. Laterisation processes. São Paulo: Universidade de São Paulo, 1982. p.331-343.

BOULET, R.; CHAUVEL, A. HUMBEL, F.X; LUCA, Y. Analyse structurale et cartographie em pédologie. Cahiers ORSTOM Séries Pédologie, v.XIX, n.4, p.309$351,1982$.

BOUMA, J. Hydrology and soil genesis of soils with aquic moisture regimes. In: WILDING, L.P.; SMECK, N.E.; HALL, G.F (Ed.). Pedogenesis and soil taxonomy. I. Concepts and interactions. Netherlands: Elsevier Science Publishers B.V., 1983. cap. 9, p.253-281.

BOURMAN, R.P. Modes of ferricrete genesis: evidence from southeastern Australia. Zeitscherift Fïr Geomorphologie, N.F., v.37, p.77-101, 1993.

BOURMAN, R.P.; MILNES, A.R.; OADES, J.M. Investigations of ferricretes and related surficial ferruginous materials in parts of southern and eastern Australia. Zeitschrift Für Geomorphologie. Laterites: Some aspects of current reserch. p.124, 1987. Supplementband, 64.

BRAUN, J.J; PAGEL, M; MULLER, J.P; BILONG, P.; MICHARD, A.; GUILLET, B.

Cerium anomalies in lateritic profiles. Geochimica et Cosmochimica Acta, v.54, p.781-795, 1990.

BREWER, R. Fabric and mineral analysis os soils. New York: Robert E. Krieger Publishing Company, 1976. 482p.

BRINKMAN, R. Ferrolysis, a hydromorphic soil forming process. Geoderma, v.3, p.199-206, 1970.

BROWN, G. (Ed.) The $x$-ray identification and crystal structures of clay minerals. London: Jarrold and Sons Ltd., 1961. 544p. 
BUURMAN, P.; LAGEN, B van; VELTHORST; E.J. Manual for soil and water analysis. Wageningen: Backhuys Publihers Leiden, 1996. 314p.

CAMARGO, M.N.; KLANT, E.; KAUFFTAMAN, J.H. Classificação de solos usada em levantamentos pedológicos no Brasil. Separata do Boletim Informativo da Revista Brasileira de Ciência do Solo, Campinas, v.12, p.11-33, 1987.

CASTRO, S.S. Impregnação de amostras de solos para confecção de lâmina delgada. Boletim Informativo da Sociedade Brasileira de Ciência do Solo, Campinas, v.10, n.2, p.44, 1985.

CASTRO, S.S. de. Sistema de transformação pedológica em Marilia: B latossólicos e B texturais. São Paulo, 1989. 274p. Tese (Doutorado) - Faculdade de Filosofia, Letras e Ciências Humanas, Universidade de São Paulo.

CASTRO, S.S. Micromorfologia de solos - Pequeno guia prático para descrição de lâminas delgadas. São Paulo, 87p. 1989. Mimeografado.

CHAO, T.T.; ZHOU, L. Extraction techniques for selective dissolution of amorphous iron oxides from soils and sediments. Soil Science Society of America Journal, v.47, n.2, p.225-232, March/April, 1983.

CHAUVEL, A. Iniciação à análise microscópica dos solos. Piracicaba: ESALQ/USP, 1979. 345p. Mimeografado.

CHAUVEL, A.; BOULET, R.; JOIN, P.; BOCQUIER, G. Aluminium and ironhydroxide segregation in nodules of latosols developed on tertiary sediments (Barreiras Group), near Manaus (Amazon Basin), Brazil. In: II INTERNATIONAL SEMINAR ON LATERITISATION PROCESSES, São Paulo, 1982. Laterisation processes. São Paulo: Universidade de São Paulo, 1982. p.507-526.

CHILDS, C.W. Composition of iron-manganese concretions from some New Zealand soils. Geoderma, v.13, n.1, p.141-152, Feb. 1975.

COELHO, R.M.; LEPSCH, I.F.; MENK, J.R.F. Relações solo-relevo em uma encosta com transição arenito-basalto em Jaú (SP). Revista Brasileira de Ciência do Solo, v.18, n.1, p.125-137, jan./abr. 1994.

COOPER, M. Estratigrafia e pedogênese de uma seqüência de solos B latossólico e B textural em Piracicaba (SP). Piracicaba, 1996. 136p. Dissertação (M.S.) - Escola Superior de Agricultura "Luiz de Queiroz", Universidade de São Paulo.

COSTA, A.C.S. da. Iron oxide mineralogy of soils derived from volcanic rochs in the Paraná river basin, Brazil. Ohio, 1996. 243p. Thesis (Ph.D.) - Ohio State University. 
CURI, N. (Coord.); LARACH, J.O.I; KÄMPF, N.; MONIZ, A.C.; FONTES, L.E.F. Vocabulário de ciência do solo. Campinas: Sociedade Brasileira de Ciência do Solo, 1993. 90p.

DANIELS, R.B.; PERKINS, H.F.; HAJEK, B.F; GAMBLE, E.E. Morphology of discontinuous phase plinthite and criteria for its field identification in the Southeastern United States. Soil Science Society of America Journal, v.42, n.6, p. 944-949, Nov./Dez. 1978.

DEBAVEYE, J.; DAPPER, M. Laterite, soil and landform development in Kedah, Peninsular Malaysia. Zeitschrift Für Geomorphologie. Laterites: Some aspects of current reserch. p.145-161, 1987. Supplementband, 64.

DECHEN, S.C.F. Caracterização e mineralogia de solos desenvolvidos de folhelhos e arenito. Piracicaba, 1979. 253p. Tese (Doutorado) - Escola Superior de Agricultura "Luiz de Queiroz", Universidade de São Paulo.

DECHEN, S.C.F.; DEMATTÊ, J.L.I.; MARCONI, A. Caracterização granulométrica e mineralógica de três perfis de solos desenvolvidos do arenito Bauru no Estado de São Paulo. Revista Brasileira de Ciência do Solo, v.18, n.3, p.499-511, set./dez. 1994.

DROSDOFF, M; NIKIFOROFF, C.C. Iron-manganese concretions in Dayton Soils. Soil Science, v.49, Jan/Jun. 1940.

EMPRESA BRASILEIRA DE PESQUISA AGROPECUÁRIA. Critérios para distinção de classes de solos e de fases de unidade de mapeamento. Normas em uso pelo SNLCS. Rio de Janeiro: EMBRAPA/SNLCS, 1988. 67p. (Documento n.11).

ESWARAN, H.; MOHAN, R. N.G. The microfabric of Petroplinthite. Soil Science Society of American Proceedings, v.37, p.79-82, 1973.

ESWARAN, H.;De CONINCK, F.;VARGHESE, T. Role of plinthite and related forms in soil degradation. Advances in Soil Science, v.11, p.109-127, 1990.

FAO; UNESCO; ISRIC. Soil map of the world. Wageningen: ISRIC, 1994. 140p.

FEDOROFF, N.; ESWARAN, H. Micromorphology of Ultisols. In: SOIL MICROMORPHOLOGY AND SOIL CLASSIFICATION,. Anaheim, 1982. Proceedings of a Symposium sponsored by Divisions S-5 and S-9 of the Soil Science Society of America. Madison: SSSA, 1985. p.145-164.

FITZPATRICK, E.A. Soil microscopy and micromorphology. Chichester: John Wiley \& Sons Ltd., 1993. 304p. 
FITZPATRICK, R.W.; SCHWERTMANN, U. Al- substituted goethite - An indicator of pedogenic and other weathering environments in South Africa. Geoderma, v.27, n.4, p.335-347, June, 1982.

FITZPATRICK, R.W.; TAYLOR, R.M.; SCHWERTMANN, V.; CHILDS, C.W. Ocorrence and proporties of lepidocrocite in some soils of New Zealand, South Africa and Australia. Australian Journal of Soil Research, v.23, p.543-567, 1985.

FLAGEOLLET, J.C. Aspects morphoscopiques et exoscopiques des quartz dans quelques sols ferrallitiques de la région de Cechi (Côte d'Uvoire). Cahiers O.R.S.T.O.M., série Pédologie, v.XVIII, n.2, 1980-1981.

FOLK, R.L.; WARD, W.C. Brazos river bar: a study in the significance of grain size parameters. Journal of Sedimentary Petrology, v.27, n.1, p.3-26, March, 1957.

FÖLSTER, H.; KALK, E.; MOSHREFI, N. Complex pedogenesis of ferrallitic savanna soils in south Sudan. Geoderma, v.6, n.2, p.135-149, Sep. 1971.

GALLAHER, R.N.; PERKINS, H.F; RADCLIFFE, D. Soil concretions: I. X-ray spectrograph and eletron microprobe analyses. Soil Science Society of America Proccedings, v.37, n.3, p.465-468, May-June, 1973.

GALLAHER, R.N.; PERKINS, H.F.; TAN, K.H. Chemical and mineralogical changes in glaebules and enclosing soil with depth in a plinthic soil. Soil Science, v.117, n.6, p.336-342, Jan./June, 1974.

GAMBLE, E. Origin and morphogenetic relations of sandy surficial horizons of upper coastal plain soils of North Carolina. Raleigh, 1966. 253p. Thesis (Ph.D.) University of North Carolina.

GAMBLE, E.E.; DANIELS, R.B. Iron and silica in water, acid ammonium oxalate, and dithionite extracts of some North Carolina coastal plain soils. Soil Science Society of America Proceedings, v.36, n.6, p. 939-943, Nov/Dec, 1972.

GAMBrelL, R.P. Manganese. In: Methods of Soil Analysis. Chemical Methods. Madison: Soil Science Society of America, 1966. Part 3, p.665-682. (Book Series, n.5).

GOLDBERY, R.; BEYTH, M. Laterization and ground water alteration phenomena in the Triassic Budra Formation,south-western Sinai. Sedimentology, v.31, p.575-594, 1984.

GUILLET, B; JEANROY, E. Note sur une methode chimique d'evaluation des substitutions alumineuses dans les oxydes et/ou oxyhydroxydes de fer. Science du sol, n. 1985/1, p37-40, 1985. 
HAMILTON, R. Microscopic studies of laterite formations. In: WORKING MEETING ON SOIL MICROMORPHOLOGY, 2, Amsterdan, 1964. Proceedings. Amsterdan: Elsevier, 1964. 269-276.

HOLMGREN, G.G.S. A rapid citrate-dithionite extractable iron procedure. Soil Science Society of America Proceedings, v.31, n.2, p.210-211, March/April, 1967. HUMBERT, R.P. The genesis of laterite. Soil Science, v.65, p.281-290, Jan./Jun. 1948. IBANGA, I.J. The physical, chemical, and mineralogical properties of laterite samples formed in various environments. Raleigh, 1980. 120p. Thesis (Ph.D.) - University of Raleigh.

IBANGA, I.J.; BUOL, S.W.; WEED, S.B.; BOWEN, L.H. Iron oxides in petroferric materials. Soil Science Society of America Journal, v.47, n.6, p.1240-1246, Nov./Dec., 1983.

INSTITUTO DE PESQUISAS TECNOLÓGICAS DO ESTADO DE SÃO PAULO. Mapa Geológico do Estado de São Paulo. Escala 1:500.000. São Paulo: IPT, 1981a. v.1. $126 \mathrm{p}$.

INSTITUTO DE PESQUISAS TECNOLÓGICAS DO ESTADO DE SÃO PAULO. Mapa Geomorfológico do Estado de São Paulo. São Paulo: IPT, 1981b. v.1. 94p. JACKSON, M.L. Soil chemical analysis advanced course. 2.ed. Madison: published by the author, $1969.895 \mathrm{p}$.

JIMENEZ-RUEDA, J.R.; DEMATTÊ, J.L.I. Solos originários de lamitos da formação Marilia (Grupo Bauru) da região de Monte Alto, SP. Revista Brasileira de Ciência do Solo, v.12., n.2, maio/ago. 1988.

KÄMPF, N.; KLANT, E.; SCHNEIDER, P. Óxidos de ferro em Latossolos do Brasil Sudeste e Sul. In: REUNIÃO DE CLASSIFICAÇÃO E CORRELAÇÃO DE SOLOS E INTERPRETAÇÃO DE APTIDÃO AGRÍCOLA, Rio de Janeiro, 1988. Anais. Rio de Janeiro: EMBRAPA-SNLCS, 1988. p.153-183.

KÄMPF, N.; SCHWERTMANN, U. Goethite and hematite in a climosequence in southern Brazil and their application in classification of kaolinitic soils. Geoderma, v.29, n.1, p.27-39, Jan. 1983.

KÄMPF, N.;SCHWERTMANN, U. The 5-M-NaOH concentration treatment for iron oxides in soils. Clays and Clay Minerals, v.30, n.6, p.401-408, 1982.

KING, H.B.; TORRANCE, J.K.; BOWEN, L.H.; WANG, C. Iron concretions in a Typic Dystrochrept in Taiwan. Soil Science Society of America Journal, v.54, p.462-468, Marc/Apr. 1990. 
LADEIRA, F.S.B. Estudo micromorfológico de uma latossolo roxo no Município de Guaira - SP. São Paulo, 1995. 93p. Dissertação (M.S.) - Faculdade de Filosofia, Letras e Ciências Humanas, Universidade de São Paulo.

LEE, R; TAYLOR, M.D.; DALY, B.K. The extraction of Al, Fe and Si from a range of New Zealand soils by hydroxylamine and ammonium oxalate solutions. Australian Journal of Soil Research, v.27, n.2, p.377-388, 1989

LEMOS, R.C. de; SANTOS, R.D. dos. Manual de descrição e coleta de solo no campo. Terceira edição. Campinas: Sociedade Brasileira de Ciência do Solo - Centro Nacional de Pesquisa de Solos, 1996. 83p.

LEPRUN, J.C. Some principal features of ironcrusts in dry western Africa. In: INTERNATIONAL SEMINAR LATERITISATION PROCESSES, Trivandrum, 1979. Proceedings. New Delhi: Oxford \& IBH Publ. Co., 1981. p.144-153.

LEPSCH, I.F.; BUOL, S.W.; DANIELS, R.B. Soil landscape relationships in the Occidental Plateau of São Paulo State, Brazil: Part I. Geomorphic surfaces and soil mapping units. Soil Science Society of America Journal, v.41, n.1, p.104-109, 1977a.

LEPSCH, I.F.; BUOL, S.W.; DANIELS, R.B. Soil landscape relationships in the Occidental Plateau of São Paulo State, Brazil: Part II. Soil morphology, genesis and classification. Soil Science Society of America Journal, v.41, n.1, p.109-115, 1977b.

LEPSCH, I.F; ROTTA, C.L.; VALADARES, J.M.A.S. Mineralogia, classificação e formas de potássico em solos da Estação Experimental de Pindorama. Revista Brasileira de Ciência do Solo, v.2., n.1, jan/abr. 1978.

LEPSCH, I.F.; VALADARES, J.M.A.S. Levantamente pedológico detalhado da Estação Experimental de Pindorama, SP. Bragantia, v.35, n.2, 13-39, jan. 1976.

LIER, Q.J. van; VIDAL-TORRADO, P. PHI: programa de microcomputador para análise estatística da granulometria de sedimentos. Revista Brasileira de Ciência do Solo, v.16, n.6, p.277-281, maio/ago. 1992.

MAcFARLANE, M.J. Mechanisms for laterisation and the formation of erosion surfaces in parts of east and southern Africa. Bulletin de la Societé géographique de Liège, v.27, p.149-155, 1991.

MAcKENZIE, R.M. Manganese oxides and hydroxides. In: : DIXON, J.B.; WEED, S.B. (Ed.). Mineral in soil environments.. Second edition. Madison: Soil Science Society of America, 1989. cap.9, p.439-461. 
MAIGNIEN, R. Compterendu de recherches sur les latérites. Paris: VaillantCarmanne, 1966. 155p.

MANN, A.W. P; OLLIER, C.D. Chemical diffusion and ferricrete formation. Catena. Soil and Geomorphology, p.151-157, 1985. Supplement, n.6.

MARQUES JÚNIOR, J.; Distribuição e atributos dos solos em relação à forma e evolução de uma vertente em Monte Alto, SP. Piracicaba, 1995. 228p. Tese (Doutorado) - Escola Superior de Agricultura "Luiz de Queiroz", Universidade de São Paulo.

McFARLANE, M.J. Laterite and Landscape. New York: Academic Press, 1976. $151 \mathrm{p}$.

McFARLANE, M.J. Laterites. In: GOUDIE, A.; PYE, K. Chemical Sediments and Geomorphology. London: Academic Press, 1983, p.7-58.

McFARLANE, M.J. Mechanisms for lateritisation and the formation of erosion surfaces in parts of east and southern Africa. Bulletin de la Société géographique de Liège, v.27, p.149-155, 1991.

McKEAGUE, J.A.; BRYDON, J.E.; MILES, N.M. Differentiation of forms of extractable iron and aluminum in soils. Soil Science Society of America Proceedings, v.35, n.1, p.33-38, Jan./Feb. 1971.

McKEAGUE, J.A.; DAY, J.H. Dithionite-and oxalate-extractable $\mathrm{Fe}$ and $\mathrm{Al}$ as aids in differentiating various classes of soils. Canadian Journal of Soil Science, v.46, n.1, p.13-22, feb. 1966.

McKENZIE, R.M. Manganese Oxides and Hydroxides. Iron oxides. In: DIXON, J.B.; WEED, S.B. (Ed.). Mineral in soil environments.. Second edition. Madison: Soil Science Society of America, 1989. cap.9, p.439-461.

MILNES, A.R. ;BOURMAN, R.P.; NORTHCOTE, K.H. Field relationships of ferricretes and weathered zones in southern south Australia: A contribution to 'Laterite' studies in Australia. Australian Journal of Soil Research, v.23, n.4, p.441465, 1985.

MILNES, A.R.; FITZPATRICK, R.W. Titanium and Zirconium Minerals. In: DIXON, J.B.; WEED, S.B. (Ed.). Mineral in soil environments.. Second edition. Madison: Soil Science Society of America, 1989. cap.23, p.1132-1194.

MOORE, T.R. The distribuition of iron, manganese, and aluminium in some soils from north-east Scotland. Journal of Soil Science. v. 24, n.2, p. 162-171, 1973. 
MULLER, D; BOCQUIER, G.; NAHON, D.; PAQUET, H. Analyse des différenciations minéralogiques et structurales dún sol ferrallitique à horizons nodulairs du Congo. Cashiers O.R.S.T.O.M., série Pédologie, v. XVIII, n.2, p.87-109, 1980 1981.

MULLER, J.P.; BOCQUIER, G. Dissolution of kaolinites and accumulation of iron oxides in lateritic ferruginous nodules: mineralogical and microstructural transformations. Geoderma, v.37, n.2, p.113-136, March, 1986.

NAHON, D. Cuirasses ferrugineuses et encroutements calcaires au Sénégal Occidental et en Mauritanie systèmes évolutifs: géochimie, structures, relais et coexistence. Marseille, 1976. 231p. Thesis (PhD.) - Faculté des Sciences et Techniques SaintJérôme

NAHON, D. Evolution of iron crusts in tropical landscapes. In: COLMAN, S.M.; DETHIER, D.P. (Eds). Rates of Chemical Weathering of Rocks and Minerals. New York: Academic Press, 1986. p.169-191.

NAHON, D.; JANOT, C.; KARPOFF, A.M.; PAQUET,H.; TARDY,Y. Mineralogy, petrography and structures of iron crusts (ferricretes) developed on sandstones in the western part of Senegal. Geoderma, v.19, p.263-277, Dec. 1977.

NAHON, D.; MELFI, A.; CONTE, C.N. Présence d'un vicux système de cuirasses ferrugineuses latéritiques en Amazonie du Sud. Sa transformation in situ en latosols sous la forêt équatoriale actuelle. C. R. Acad. Sci. Paris, t.308, Série II, p.755-760, 1989.

NAHON, D.B. Self-organization in chemical lateritic weathering. Geoderma, v.51, p.513,1991 .

NETTO, A.R. Influência da mineralogia da fração argila sobre propriedades físicoquímicas de solos brasileiros. Viçosa, 1996. 144p. Dissertação (M.S.) Universidade Federal de Viçosa.

NORRISH, K.; TAYLOR, R.M. The isomorphous replacement of iron by aluminium in soil goethites. Journal of Soil Science, v.12, n. 2, p.296-306, 1961.

OLIVEIRA, J.B. de; MENK, J.R.F. Latossolos do Estado de São Paulo. Campinas: Instituto Agronômico, 1984. 132p. (Boletim Técnico, n.82).

OLIVEIRA, J.B.; JACOMINE, P.K.T.; CAMARGO, M.N. Classes gerais de solos do Brasil. Segunda edição. Jaboticabal: FUNEP, 1992. 201p

OLLIER, C.D. A. Laterite profiles, ferricrete and landscape evolution. Zeitscherift Für Geomorphologie, N.F., v.35, n.2, p.165-173, June, 1991. 
PARTIFF, R.L.; CHILDS, C.W. Estimation of forms of $\mathrm{Fe}$ and $\mathrm{Al}$ : a review, and analysis of contrasting soils by dissolution and Moessbauer methods. Australian Journal of Soil Research, v.26, n.1, p. 121-144,1988.

PEDRO,G.; MELFI, A.J. The superficial alteration in tropical region and the lateritisation phenomena. In: II INTERNATIONAL SEMINAR ON LATERITISATION PROCESSES, São Paulo, 1982. Laterisation processes. São Paulo: Universidade de São Paulo, 1982. p. 3-13.

PIPER, D.Z. Rare earth elements in ferromanganese nodules and other marine phases.

Geochimica et Cosmochimica Acta, v.38, p.1007-1022, 1974

RAIJ, B. van; QUAGGIO, J. A.; CANTARELLA, H; FERREIRA, M. E.; LOPES, A. S.; BATAGLIA, O. C. Análise química do solo para fins de fertilidade. Campinas: Fundação Cargill, 1987. 170p.

RAIJ,B. van; VALADARES, J.M.A.S. Análise dos elementos maiores de rochas, argilas e solos. Campinas: IAC/Seção de Pedologia, Divisão de Solos, 1974. 23p. (IAC. Boletim Técnico, n. 16)

RESENDE, M.; BAHIA FILHO, A.F.C.; BRAGA, J.M. Mineralogia da argila de Latossolos estimada por alocação a partir do teor total de óxidos do ataque sulfúrico. Revista Brasileira de Ciência do Solo, v.11, p.17-23, jan./abr. 1987.

RHOTON, F.E.; BIGHAM, J.M; SCHULZE, D.G. Properties of iron-manganese nodules from a sequence of eroded fragipan soils. Soil Science Society of America Journal, v.57, p.1386-1392, Sep/Oct. 1993.

RHOTON, F.E.; J.M., BIGHAM, J.M.; NORTON, L.D. Contribuition of magnetite to oxalate-extractable iron in soils and sediments from the Maumee river basin of Ohio. Soil Science Society of America Journal, v.45, n.3, p.645-649, May/June, 1981.

ROQUIN, C. Element distribuition patterns in laterites of southern Mali: consequence for geochemical prospecting and mineral exploration. Applied Geochemistry, v.5, p.303-315, 1990.

ROQUIN, C.; FREYSSINET, PH; ZEEGERS, H.; TARDY, Y. Element distribuition patterns in laterites of southern Mali: consequence for geochimical prospecting and mineral exploration. Applied Geochemistry, v.5, p.303-315, 1990a. 
ROQUIN, C; PAQUET, H.; FREYSSINET, P.; BOEGLIN, J.L.; TARDY, Y. Lithodependence and homogeization of mineralogical and chemical composition of ferricretes. Chemical Geology. Geochemistry of the earth's surface and of mineral formation. v. 84, p.124-137, July, 1990b. Special Issue

ROSS, G.J.; WANG, C.; SCHUPPLI, PA. Hydroxylamine and ammonium oxalate solutions as extractants for iron and aluminium from soils. Soil Science Society of America Journal, v.49, n.3, p. 783-785, may/june, 1985.

SCHELLMANN, W. Considerations on the definition and classification of laterites. In: INTERNATIONAL SEMINAR LATERITISATION PROCESSES, Trivandrum, 1979. Proceedings. Rotterdam: Oxford \& IBH Publ. Co., 1981. p.1-10.

SCHELLMANN, W. Geochemical differentiation in laterite and bauxite formation. Catena, v.21, n.2-3, p.131-143, Feb. 1994.

SCHULZE, D.G. The identification of iron oxides by differential x-ray diffaction and the influence of aluminum substitution on the structure of goethite. Weihenstephan, 1982 167p. Thesis (Ph.D.) - Universität München.

SCHWARZ, T. Ferricrete formation and relief inversion: an example from Central Sudan. Catena, v.21, 1994.

SCHWERTMANN, U. Use of oxalate for Fe extraction from soils. Canadian Journal of Soil Science, v.53, p.244-246, May, 1973

SCHWERTMANN, U.; FANNING, D.S. Iron-manganase Concretions in Hydrosequences of Soils in Loess in Bavaria. Soil Science Society of America Journal, v.40, p.731-738, Sept/Oct. 1976.

SCHWERTMANN, U.; KÄMPF, N. Óxidos de ferro jovens em ambientes pedogenéticos brasileiros. Revista Brasileira de Ciência do Solo, v.7, n. 1,p.251-255, jan./abr. 1983.

SCHWERTMANN, U; LATHAM, M. Properties of iron oxides in some new caledonian oxisols. Geoderma, v.39, n.2, p.105-123, Dec. 1986.

SCHWERTMANN, U; TAYLOR, R.M. Iron oxides. In: DIXON, J.B.; WEED, S.B. (Ed.). Mineral in soil environments.. Second edition. Madison: Soil Science Society of America, 1989. cap.8, p.380-427.

SHADFAN, H.; DIXON, J.B.; CALHOUN, F.G. Iron oxide properties versus strength of ferruginous crust and iron-glaebules in soils. Soil Science, v.140, n.5, p.317-325, July/Dec. 1985 
SIDHU, P.S.; SEHGAL, J.L.; SINHA, M.K.; RANDHAWA, N.S. Composition and mineralogy of iron-manganese concretions from some soils of the Indo-Gangetic Plain in northwest India. Geoderma, v. 18, n.4, p.241-249, Aug. 1977.

SIVARAJASINGHAM, S.; ALEXANDER, L.T.; CADY, J.G.; CLINE, M.G. Laterite. Advances in Agronomy, v. 14, p.1-60, 1962.

SOARES, P.C.; LANDIM, P.M.B.; FÚLFARO, V.J.; NETO SOBREIRO, A.F. Ensaio de caracterização estratigráfica do cretáceo no Estado de São Paulo: Grupo Bauru. Revista Brasileira de Geociências, v.10, n.3, p.177-235, sep. 1980.

SOIL SURVEY STAFF. Department of Agriculture. Soil Conservation Service. Sixth edition. Keys to Soil Taxonomy. Washington: USDA, 1994. 306p.

SOIL SURVEY STAFF. Department of Agriculture. Soil Taxonomy: A basic system of soil classification for making and interpreting soil surveys. Handbook 436. Washington: USDA, 1975. 754p.

SPAROVEK, G. Amostragem e análise de dados edafo-bio-climáticos de um remanescente florestal no município de Pindorama (SP). Piracicaba, 1993. 132p. Tese (Doutorado) - Escola Superior de Agricultura "Luiz de Queiroz", Universidade de São Paulo.

TARDY, Y. Diversity and terminology of lateritic profiles. In: MARTINI, I.P.; CHESWORTH, W. Weathering Soils \& Paleosols. Guelf: Elsevier, 1992. cap.15, p.379-405.

TARDY, Y. Pétrologie des latérites et des sols tropicaux. Paris: Masson, 1993. $459 \mathrm{p}$.

TARDY, Y.; BARDOSSY, G.; NAHON, D. Fluctuations de l'activité de léau et successions de minéraux hydratés et déshydratés au sein des profils latéritiques ferrugineus et bauxitiques. C. R. Acad. Sci. Paris, v.307, Série II, p.753-759, 1988.

TARDY, Y.; KOBILSEK, B.PAQUET, H. Mineralogical composition and geographical distribuition of African and Brazilian periatlantic laterites. The influence of continental drift and tropical paleoclimates during the past 150 million years and implications for India and Australia. Journal of African Earth Sciences, v.12, n.1-2, p.283-295, 1991. 
TARDY, Y.; MELFI, A.J.; VALETON, I. Climats et paléoclimats tropicaux périatlantiques. Rôle des facteurs climatiques et thermodynamiques: température et activité de l'eau, sur la répartition et la composition minéralogique des bauxites et des cuirasses ferrugineuses, ay Brésil et en Afrique. C. R. Acad. Sci. Paris, t. 306, série II, p. 289-295, 1988.

TARDY, Y; NAHON, D. Geochemistry of laterites,stability of Al-Goethite,AlHematite, and $\mathrm{Fe}^{+3}-$ kaolinite in bauxites and ferricretes: An approach to the mechanism of concretion formation. American Journal of Science, v.285, p.865903, Dec. 1985.

TARDY, Y.; NOVIKOFF, A. Activité de l'eau et déplacement des équilibres gibbsitekaolinite dans les profils latéritiques. C. R. Acad. Sci. Paris, v.306,série II, p.39-44, 1988.

TARDY, Y; KOSILSEK, B.; PAQUET, H. Mineralogical composition and goegraphical distribuition of african and brazilian periatlantic laterites. The influence of continental drift and tropical paleoclimates during the past 150 million years and implications for India and Australia. Jornal of African Earth Sciences, v. 12, n. 1-2, p.283-295, 1991.

TARDY, Y; ROQUIN, C. Geochemistry and evolution of lateritic landscapes. In: MARTINI, I.P.; CHESWORTH, W. Weathering Soils \& Paleosols. Guelf: Elsevier, 1992. cap.16, p.407-433.

TAYLOR, R.M. The association of manganese and cobalt in soils - further observations. Journal of Soil Science, v. 19, n.1, p.77-80, 1968.

TAYLOR, R.M; McKENZIE, R.M. The association of trace elements with manganese minerals in Australian soils. Australian Journal of Soil Research, v.2, p.235-248, 1966.

TERAMOTO, E.R. Relações solo, substrato geológico e superficies geomórficas na microbacia do Ribeirão Marins (Piracicaba, SP). Piracicaba, 1995. 120p. Dissertação (M.S.) - Escola Superior de Agricultura "Luiz de Queiroz", Universidade de São Paulo.

THOMAS, M.F. Geomorphology in the tropics. A study of weathering and denudation in low latitudes. Union King: Wiley, 1994. 460p.

THORNSTWAITE, C. $\dot{W}$. \& MATTER, J.R. The water balance. CENTERTON, N.J; Drexed Institute of Tecnology, 1955. 104p. (Publications in climatology, v.8, n.1). 
TORRENT, J.; SCHWERTMANN, U.; SCHULZE, D.G. Iron oxide mineralogy of some soils of two river terrace sequences in Spain. Geoderma, v.23, n.3, p.191208, April, 1980.

TREMOCOLDI, W.A. Study of a toposequence of soils derived from Bauru Sandstone, in the State of São Paulo. West Lafayette, 1982. 92p. Thesis (M.S.) - Purdue University.

TRENDALL, A.F. The formation of "apparent peneplains" by a process of combined lateritisation and surface wash. Zeitscherift Für Geomorphologie, N.F., v.6, p.183197, 1962.

TROLARD, F.; TARDY, Y. The stabilities of gibbsite, boehmite, aluminous goethites and aluminous hematites in bauxites, ferricretes and laterites as a functions of water activity,temperature and particle size. Geochimica et Cosmochimica Acta, v.51, n. 54, p.945-957, April, 1987.

TROLARD, F; TARDY, Y. A model of $\mathrm{Fe}^{3+}$ - caolinite, $\mathrm{Al}^{3+}$ - goethite, $\mathrm{Al}^{3+}$ - hematite equilibria en laterites. Clay Minerals, v.24, p.1-21, 1989.

VETTORI, L. Métodos de análise de solos. Rio de Janeiro: EPE - Ministério da Agricultura, 1969. 24p. (Boletim técnico, n.7).

WOOD, B.W.; PERKINS, H.F. A field method for verifying plinthite in southern coastal plain soils. Soil Science, v.122, n.4, p.240-241, 1976.

WRIGHT, V.P.; SLOAN, R.J.; GARCÉS, B.V.; GARVIE, L.A.J. Groundwater ferricretes from the Silurian of Ireland and Permian of the Spanish Pyrenees. Sedimentary Geology, v.77, p.37-49, 1992. 
APÊNDICE 1

DESCRIÇÃO MORFOLÓGICA DOS PERFIS 


\section{Perfil P1}

Classificação: PLINTOSSOLO PÉTRICO DISTRÓFICO Tb A moderado textura arenosa.

\section{Horizonte Morfologia}

A

0-10 cm; bruno-escuro (7,5 YR 4/2, úmido e 7,5 YR 5/3, seco); areia franca; moderada, pequena e média, blocos subangulares se desfazendo em granular muito pequena de grau fraco; macia, muito friável, não plástica, não pegajosa; transição clara e ondulada. Nódulos: muito pouco, pequenos $(0,3 \mathrm{~cm})$, duros, irregulares, vermelhos e ferruginosos.

$\mathbf{E}$

10-25 cm, bruno-escuro (7,5 YR 4/4, úmido e 7,5 YR 4/6 seco), areia franca; fraco, médio e grande, blocos subangulares se desfazendo em grãos simples; ligeiramente dura, friável, não plástica e não pegajosa; transição plana e abrupta. Nódulos: muito pouco, pequenos $(0,3 \mathrm{~cm})$, duros, irregulares, vermelhas, ferruginosos.

F1

25-45 cm; $80 \%$ nódulos e 20\% matriz; matriz com cor vermelhoamarelado (5 YR 4/6, úmido e 5 YR 4,5/6 seco), plástica e pegajosa; transição plana e abrupta. Nódulos petroplínticos: dominante; grande, duro, irregulares, vermelhos e ferruginosos.

F2 45-55 cm; 40\% nódulos e 60\% matriz; matriz com cor vermelhoamarelado (5YR 4/6, úmido e 5 YR 4/4, seco), plástica e pegajosa; transição plana e abrupta. Nódulos plínticos: freqüentes, grande, duro, irregulares, vermelho-amarelados e ferruginosos. 
Cr 55-116 cm; vermelho (2,5 YR 4/8, úmido e 2,5 YR 3/6 seco); franco argiloarenosa; estrutura original da rocha; duro, muito firme, plástica e pegajosa, transição ondulada e gradual. Cerosidade forte e abundante de cor bruno-forte $(7,5$ YR $5 / 6$, úmido) revestindo os fragmentos saprolíticos.

Crg1 116-140 cm; coloração variegada, úmida, composta de vermelho $(2,5$ YR 4/8), amarela-avermelhada (7,5 YR 6/6) e cinza (5YR 6/1); franco argiloarenosa; estrutura original da rocha; ligeiramente dura, firme, plástica e pegajosa, transição ondulada e gradual.

Crg2 140-180 cm +; coloração variegada, úmida, composta de amarelaavermelhado (7,5 YR 6/6), vermelho (2,5 YR 4/6) e cinza (5YR 6/1); areia franca; estrutura original da rocha, ligeiramente dura, firme, plástica e pegajosa. 
Perfil P2

Classificação: PODZÓLICO VERMELHO-AMARELO ABRUPTO PÉTRICO EUTRÓFICO Tb A moderado textura arenosa/média.

\section{Horizonte Morfologia}

A

0-10 cm; bruno (7,5 YR 4/2, úmido e 7,5 YR 4/4, seco); areia franca; fraca, média, blocos subangulares; macia, friável, não plástica e não pegajosa, transição ondulada e clara. Nódulos: muito pouco, pequenos $(0,3 \mathrm{~cm})$, duros, irregulares, vermelhos e ferruginosos.

$\mathbf{E}$

10-26 cm; bruno (7,5 YR 4/4, úmido e 7,5 YR 5/4); areia franca, fraca, média, blocos subangulares; ligeiramente dura, friável, não plástica e não pegajosa; transição plana e abrupta. Nódulos: muito pouco, pequenos $(0,3$ $\mathrm{cm}$ ), duros, irregulares, vermelhos e ferruginosos.

Bt1

26-38 cm; vermelho-amarelado (5 YR 4/6, úmido e 7,5 YR 4/8, seco); franco argiloarenosa; moderado, médio e grande, blocos subangulares; dura, firme, ligeiramente plástico e ligeiramente pegajoso; transição plana e gradual. Nódulos: muito pouco, pequenos $(0,3 \mathrm{~cm})$, duros, vermelhos e ferruginosos.

Bt2

38-60 cm; vermelho-amarelado ( 5 YR 4/8, úmido e $5 \mathrm{YR} \mathrm{5/4,} \mathrm{seco);}$ franco argiloarenosa; moderado, médio e grande, blocos subangulares; dura, firme, plástica e pegajosa; transição ondulada e abrupta. Nódulos: muito pouco, pequenos $(0,35 \mathrm{~cm})$, duros, vermelhos e ferruginosos.

F1 $60-85 \mathrm{~cm} ; 80 \%$ nódulos e $20 \%$ matriz; matriz com cor vermelhoamarelado ( 5 YR 4/6, úmido e 5 YR $5 / 6$ seco), plástica e pegajosa; transição ondulada e abrupta. Nódulos petroplínticos: dominante; grande, duro, irregulares, vermelhos e ferruginosos. 
F2

$85-110 \mathrm{~cm} ; 60 \%$ nódulos e $40 \%$ matriz; matriz com cor vermelhoamarelado ( 5 YR 4/8, úmido e 5 YR 5/8), plástica e pegajosa; transição ondulada e abrupta. Nódulos plínticos: muito freqüente, grandes, duros, irregulares, vermelho-amarelados e ferruginosos.

Cr 110-164 cm; vermelho (2,5 YR 4/6, úmido e 2,5 YR 5/6, seco); franco argiloarenosa; estrutura original da rocha, ligeiramente dura, firme, plástica e pegajosa; transição ondulada e clara. Presença de um "coating" enegrecido de manganês (preto, 2,5 YR 2,5/0, úmida) revestindo os fragmentos saprolíticos.

$\mathbf{R}$

164-190 cm +; vermelho (2,5 YR 4/6, úmido e 2,5 UYR 5/6, seco); franco arenosa; estrutura da rocha, dura, muito firme, plástica e pegajosa. Presença de um "coating" enegrecido (2,5 YR 2,5/0, úmido) nas fraturas da rocha. 


\title{
Perfil P3
}

Classificação:

\author{
PODZÓLICO VERMELHO-AMARELO \\ MODERADAMENTE \\ DRENADO
}

ABRUPTO

DISTRÓFICO

EPIEUTRÓFICO Tb A moderado textura arenosa/média.

\section{Horizonte Morfologia}

A

0-13 cm; bruno-escuro (7,5 YR 3/2, úmido e 7,5 YR 4/3, seco); areia franca; fraca, pequena e muito pequena, blocos subangulares se desfazendo em granular pequena e média de grau fraco; macia, friável, não plástica e não pegajosa; transição ondulada e abrupta.

EA 13-24 cm; bruno (7,5 YR 4/4, úmido e 7,5 YR 5/4, seco); areia franca; fraca, média, blocos subangulares se desfazendo em grãos simples; ligeiramente dura, friável, não plástica e não pegajosa; transição plana e clara.

E $24-67 \mathrm{~cm}$; bruno (7,5 YR 5/4, úmido e 7,5 YR 6/4, seco); areia franca; fraca, média, blocos subangulares se desfazendo em grãos simples; macia, muito friável, não plástica e não pegajosa; transição ondulada e abrupta.

Btg1 67-100 cm; horizonte mosqueado composto de cor de fundo vermelhoamarelado (5YR 4/8, úmido) e secundariamente bruno-amarelado (10YR $5 / 4$, úmido). Mosqueado comum, médio (6 $\mathrm{mm})$, distinto e vermelho (2,5 YR 4/8, úmido); franca argiloarenosa; moderada, médio e grande, blocos subangulares; dura, muito firme, ligeiramente plástica e ligeiramente pegajosa; transição ondulada e gradual.

Btg2 100-150 cm +; horizonte mosqueado com coloração de fundo variegada, composta de bruno (7,5 YR 5/4, úmido) e bruno-acinzentado (10 YR 5/2, úmido). Mosqueado abundante, médio $(8 \mathrm{~mm})$, distinto e vermelho $(2,5$ YR 4/6, úmido); moderada, médio, blocos subangulares; dura, muito firme, ligeiramente plástica e ligeiramente pegajosa. 
APÊNDICE 2

DESCRIÇÃO MICROMORFOLÓGICA DOS PERFIS ESTUDADOS 
Micromorfologia do Perfil P1. Classificação do solo: Plintossolo Pétrico distrófico Tb A moderado textura arenosa.

\begin{tabular}{|c|c|c|c|c|}
\hline \multirow[t]{2}{*}{ Atributo } & \multicolumn{4}{|c|}{ Horizonte/profundidade de coleta } \\
\hline & E/F1 (18-28cm) & $\mathrm{F} 2 / \mathrm{Cr}(50-65 \mathrm{~cm})$ & $\operatorname{Cr}(100-110 \mathrm{~cm})$ & $\operatorname{Crg2~(145-160cm)~}$ \\
\hline Plasma & $\begin{array}{l}20 \% \text {, bruno escuro, argila } \\
\text { mineralógica e óxidos de } \\
\text { ferro, isótico passando para } \\
\text { vermelho-amarelado, sila- } \\
\text { ssépica com tendência } \\
\text { vossemassépica próximo ao } \\
\text { F1. }\end{array}$ & $\begin{array}{l}20 \% \text {, vermelho-amarelado } \\
\text { predominante e localmen- } \\
\text { te vermelho escuro e } \\
\text { vermelho, argila minera- } \\
\text { lógica e oxidos de ferro } \\
\text { isótico com tendência } \\
\text { vossemassépica. }\end{array}$ & $\begin{array}{l}25 \% \text {, vermelho-amarelo } \\
\text { predominante e local - } \\
\text { mente vermelho escuro e } \\
\text { vermelho, argila } \\
\text { mineralógica e óxidos de } \\
\text { ferro, plasma silas- } \\
\text { sépico com tendência } \\
\text { vossemassépica. }\end{array}$ & $\begin{array}{l}20 \% \text {, vermelho-amarelo, } \\
\text { silassépico e raramente } \\
\text { vossépico, argila minera- } \\
\text { lógica éxidos de ferro. }\end{array}$ \\
\hline Esqueleto & $\begin{array}{lrr}40 \% & \text { quartzo } & \text { subarre } \\
\text { dondado } & \text { nas } & \text { frações } \\
\text { grosseiras } & \text { enquanto } & \text { as } \\
\text { frações } & \text { finas } & \text { são } \\
\text { subangulares, paredes lisas e } \\
\text { presença de alguns feldspatos } \\
\text { potássicos. }\end{array}$ & $\begin{array}{l}30 \% \text {, quartzo com a } \\
\text { mesma forma e exoscopia } \\
\text { do horizonte anterior, } \\
\text { apresenta alguns campos } \\
\text { selecionados com grãos } \\
\text { finos devido a atividade } \\
\text { biológica e a própria } \\
\text { litologia. }\end{array}$ & $\begin{array}{l}65 \% \text {, quartzo com a } \\
\text { mesma forma } \\
\text { exoscopia dos hori- } \\
\text { zontes anteriores, no } \\
\text { entanto, havendo um } \\
\text { aumento dos grãos } \\
\text { muito finos. }\end{array}$ & $\begin{array}{l}40 \% \text {, quartzo semethante } \\
\text { quanto a forma e } \\
\text { exoscopia aos horizontes } \\
\text { acima, variando em } \\
\text { granulometria (predomina } \\
\text { fração mais grosseira, } 350 \\
\mu \mathrm{m}) \text { e maior abundância } \\
\text { de feldspatos potássicos } \\
(2 \%) \text {. Algumas porçoes da } \\
\text { fäbrica intema são } \\
\text { dominadas por esquelato } \\
\text { triado na fração areia fina }\end{array}$ \\
\hline Poros & $\begin{array}{l}40 \% \text {, predomínio de poros de } \\
\text { arranjamento e ortocavidades } \\
\text { no } \mathrm{E} \text {, enquanto no } \mathrm{F} 1 \text {, canais, } \\
\text { orto e metacavidades. }\end{array}$ & $\begin{array}{l}50 \% \text {, ortocavidades } \\
\text { predominante, algumas } \\
\text { meta, poucos canais } \\
\text { alguma porosidade de } \\
\text { arranjamento. }\end{array}$ & $\begin{array}{l}10 \% \text {, reduziu sensivel - } \\
\text { mente em relação a } \\
\text { transição } \mathrm{F} 2 / \mathrm{Cr} \text {, predo- } \\
\text { minando ortocavidades e } \\
\text { canais irregulares. }\end{array}$ & $\begin{array}{l}40 \% \text {, ortocavidades e } \\
\text { canais irregulares, poucas } \\
\text { fissuras. }\end{array}$ \\
\hline Trama & $\begin{array}{l}\text { Gefürica oom tendência } \\
\text { chitônica no } \mathrm{E} \text {, passando } \\
\text { para porfirica fechada no F1. }\end{array}$ & $\begin{array}{l}\text { Porfirica com tendência } \\
\text { gefúrica localmente }\end{array}$ & Porfirica fechada & $\begin{array}{|lr|}\begin{array}{l}\text { Porfirica } \\
\text { tendência }\end{array} & \text { fechada com } \\
\text { localmente } & \text { gefürica } \\
\end{array}$ \\
\hline Feições & 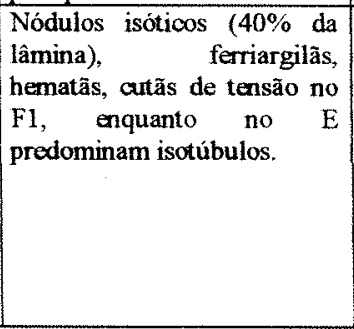 & 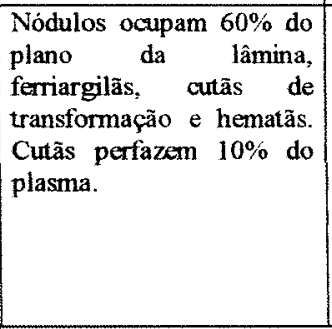 & $\begin{array}{l}\text { Cutâs ocupam } 20 \% \text { do } \\
\text { plasma e correspondem } \\
\text { a ferriargilãs de } \\
\text { iluviação, cữãs de } \\
\text { transformação e hema- } \\
\text { tãs. Também isotúbulos } \\
\text { mostram-se presentes em } \\
20 \% \text { da lâmina, } \\
\text { geralmente circulares e } \\
\text { com esqueleto triado. }\end{array}$ & $\begin{array}{|lr|}\text { Poucos cutãs } & (1 \%), \\
\text { predominando } & \text { de } \\
\text { transformação. } & \text { Presenģa } \\
\text { de isotúbulos circulares. }\end{array}$ \\
\hline
\end{tabular}


Micromorfologia do perfil P2. Classificação do solo: Podzólico Vermelho-Amarelo Abrupto Pétrico Eutrófico Tb A moderado textura arenosa/média.

\begin{tabular}{|c|c|c|c|c|c|c|c|}
\hline \multirow[t]{2}{*}{ Atributo } & \multicolumn{7}{|c|}{ Horizonte/profundidade de coleta } \\
\hline & $\begin{array}{c}E \\
(12-22 \mathrm{~cm}) \\
\end{array}$ & $\begin{array}{c}\mathbf{E} / \mathrm{Bt1} \\
(20-30 \mathrm{~cm})\end{array}$ & $\begin{array}{c}\mathrm{Bt} / \mathrm{F1} \\
(55-70 \mathrm{~cm})\end{array}$ & $\begin{array}{c}F 1 \\
(65-75) \\
\end{array}$ & $\begin{array}{c}\mathrm{F} 2 / \mathrm{Cr} \\
(105-120)\end{array}$ & $\begin{array}{c}\mathrm{Cr} \\
(140-150 \mathrm{~cm}) \\
\end{array}$ & $\begin{array}{c}\mathrm{R} \\
(175-185 \mathrm{~cm}) \\
\end{array}$ \\
\hline Plasma & $\begin{array}{l}5 \% \text {, bruno, argila } \\
\text { mineralógica e } \\
\text { oxi-dos de ferro, } \\
\text { isótico }\end{array}$ & $\begin{array}{l}20 \% \text {, bruno } \\
\text { escuro, argi- } \\
\text { la mineraló- } \\
\text { gica e oxi- } \\
\text { dos de ferro, } \\
\text { isótico. }\end{array}$ & $\begin{array}{l}30 \% \text {, verme- } \\
\text { tho-amarelo } \\
\text { predominante } \\
\text { e localmente } \\
\text { vermelho es- } \\
\text { curo e ver- } \\
\text { melho, argila } \\
\text { mineralogica e } \\
\text { oxidos de } \\
\text { ferro. Fundo } \\
\text { matricial isóti- } \\
\text { co com ten- } \\
\text { dência massé- } \\
\text { pica. }\end{array}$ & $\begin{array}{l}35 \% \text { verme- } \\
\text { lho-amarelo } \\
\text { predominante } \\
\text { e localmente } \\
\text { vermetho es- } \\
\text { curo e verme- } \\
\text { tho, argila mi- } \\
\text { neralogica e } \\
\text { óxidos de } \\
\text { ferro. Fundo } \\
\text { matricial isóti- } \\
\text { co com } \\
\text { tendência vos- } \\
\text { semassépico }\end{array}$ & $\begin{array}{l}20 \% \text { verme } \\
\text { lho-amarelo, } \\
\text { argila minera- } \\
\text { lógica e oxi- } \\
\text { dos de ferro, } \\
\text { silassépico e } \\
\text { localmente } \\
\text { vossemassé- } \\
\text { pico. }\end{array}$ & $\begin{array}{l}35 \% \text {, predo- } \\
\text { minantemente } \\
\text { vermelho, com } \\
\text { alguns } \\
\text { dominios ver- } \\
\text { melho-escuro- } \\
\text { acinzentado } \\
(5 \% \text { ), argila } \\
\text { mineralogica e } \\
\text { óxidos de ferro } \\
\text { e manganés, i- } \\
\text { sótioo e local- } \\
\text { mente silas- } \\
\text { sépico. }\end{array}$ & $\begin{array}{l}40 \% \text { predo- } \\
\text { minantemente } \\
\text { vermelho com } \\
\text { alguns domi- } \\
\text { nios vermelho } \\
\text {-escuro-acin- } \\
\text { zentado devi- } \\
\text { do a maior se- } \\
\text { gregação do } \\
\text { ferro e man- } \\
\text { ganê, argila } \\
\text { mineralógica e } \\
\text { oxidos de ferro } \\
\text { e manganês. } \\
\text { Isótico } \\
\end{array}$ \\
\hline Esqueleto & 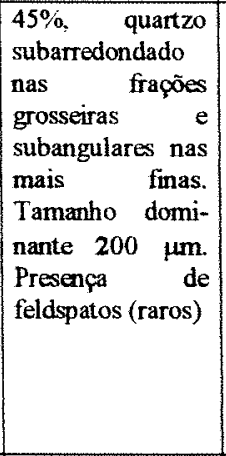 & $\begin{array}{l}35 \% \text { idem } \\
\text { anterior }\end{array}$ & $55 \%$, idem & $55 \%$, idem & $\begin{array}{|lr|}0 \%, & \text { idem, } \\
\text { porém } & \text { com } \\
\text { maiores } & \text { con- } \\
\text { teúdos } & \text { de } \\
\text { feldspatos } & \text { po- } \\
\text { tássicos } & \text { e } \\
\text { aumento } & \text { do } \\
\text { tamanho } & \text { mé } \\
\text { dio do } & \text { grão } \\
(300 \mu \mathrm{m}) & \end{array}$ & $\begin{array}{l}45 \% \text { quartzo } \\
\text { subarredonda- } \\
\text { do nas fraçães } \\
\text { areia média e } \\
\text { fina e suban- } \\
\text { gular na fra- } \\
\text { gão muito fina. } \\
\text { Tamanho } \\
\text { médio do grão: } \\
300 \text { um. } \\
\text { Algumas por- } \\
\text { cões predomi- } \\
\text { nam quartzo } \\
\text { fino. }\end{array}$ & 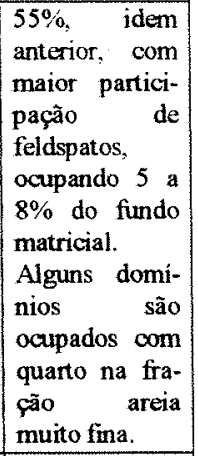 \\
\hline Poros & $\begin{array}{l}50 \% \text {, predomínio } \\
\text { de uma porosida- } \\
\text { de de arranjo e } \\
\text { ortocavidades. }\end{array}$ & \begin{tabular}{|l|}
$45 \%$, \\
predomínio \\
de ortocavi- \\
dades r \\
poros de \\
arranjo
\end{tabular} & $\begin{array}{l}15 \%, \\
\text { predominio de } \\
\text { orto e metaca- } \\
\text { vidades e } \\
\text { canais }\end{array}$ & \begin{tabular}{|l|}
$10 \%$, \\
predominio de \\
orto e metaca- \\
vidades e e \\
canais
\end{tabular} & $\begin{array}{|lr|}50 \%, & \text { predo- } \\
\text { minam } & \text { orto- } \\
\text { cavidades. No } \\
\text { entanto, mata- } \\
\text { cavidades e } \\
\text { orto e mata } \\
\text { canais estão } \\
\text { presentes. } \\
\end{array}$ & $\begin{array}{l}20 \% \text {, predo- } \\
\text { mínio de orto- } \\
\text { cavidades e } \\
\text { algumas fissu- } \\
\text { ras. }\end{array}$ & $\begin{array}{l}5 \%, \text { predomi- } \\
\text { nantemente } \\
\text { fissurais }\end{array}$ \\
\hline Trama & Chitônica. & \begin{tabular}{|l|} 
Porfirica no \\
Bt, passando \\
a gefúrica e \\
chitônica nas \\
proximi- \\
dades do E
\end{tabular} & $\begin{array}{l}\text { Porfirica fe- } \\
\text { chada. }\end{array}$ & $\begin{array}{|lr|}\text { Predomina } \\
\text { porfirica fe- } \\
\text { chada com } \\
\text { restrita porosi- } \\
\text { dade, attema- } \\
\text { das com } \\
\text { porfirica aber- } \\
\text { ta de maior } \\
\text { porosidade } \\
\end{array}$ & $\begin{array}{|lr|}\text { Porfírica } & \text { com } \\
\text { tendência } & \text { ge- } \\
\text { fúrica } & \text { local- } \\
\text { mente. } & \end{array}$ & $\begin{array}{l}\text { Porfirica } \\
\text { fechada }\end{array}$ & $\begin{array}{l}\text { Porfirica } \\
\text { fechada }\end{array}$ \\
\hline Feições & 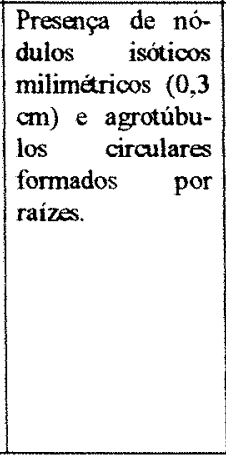 & \begin{tabular}{|l|} 
Presença de \\
nódulos isó- \\
ticos mili- \\
métricos $(0,3$ \\
mm). Raros \\
fer-riargilãs \\
de iluviação. \\
Presença de \\
agrotúbulos \\
circulares \\
formados por \\
raizes
\end{tabular} & $\begin{array}{|lr|}\text { Aumento } & \text { do } \\
\text { tamanho } & \mathrm{e} \\
\text { quantidade dos } \\
\text { nódulos } \\
\text { isótioos. } \\
\text { Presença } & \text { de } \\
\text { ferriargilãs } & \mathrm{e} \\
\text { hematãs } & \text { en } \\
\text { pequenas } & \\
\text { quantidades } \\
(1 \% \text { do } & \text { plas- } \\
\text { ma) } & \end{array}$ & 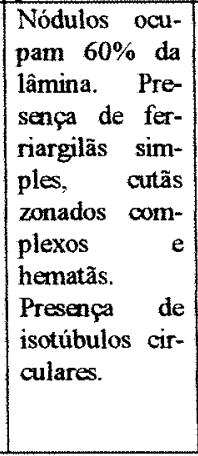 & 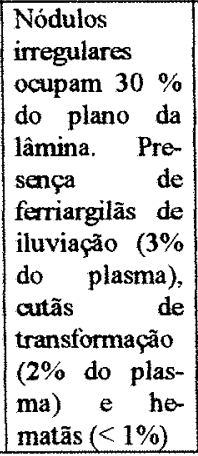 & 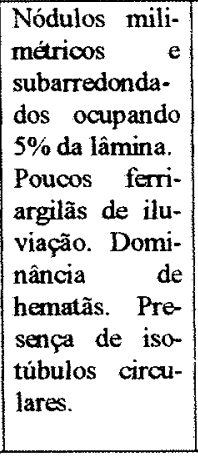 & \begin{tabular}{|l|} 
Presença de \\
neomangãs e \\
quasimangãs, \\
neoferrãs $\quad \mathrm{e}$ \\
quasiferrãs.
\end{tabular} \\
\hline
\end{tabular}


Micromorfologia do Perfil P3. Classificação do solo: Podzólico Vermelho-Amarelo Abrupto Moderadamente Drenado Distrófico Epieutrófico $\mathrm{Tb} \mathrm{A}$ moderado textura
arenosa/média.

\begin{tabular}{|c|c|c|c|c|}
\hline \multirow[t]{2}{*}{ Atributo } & \multicolumn{4}{|c|}{ Horizonte/profundidade de coleta } \\
\hline & $E(30-45 \mathrm{~cm})$ & E/Btg1 (60-75cm) & Btg1 $(85-95 \mathrm{~cm})$ & Btg2 (115-125cm) \\
\hline Plasma & $\begin{array}{l}5 \% \text {, bruno, argila minera- } \\
\text { lógica e oxidos de ferro, } \\
\text { isótio. }\end{array}$ & $\begin{array}{l}15 \% \text {, bruno escuro, argila } \\
\text { mineralogica e oxidos de } \\
\text { ferro. Isótico com domi- } \\
\text { nios silassépicos e vossé- } \\
\text { picos. }\end{array}$ & $\begin{array}{l}25 \%, \text { vermelho-amare- } \\
\text { lado silassépico domi- } \\
\text { nante (80\%), com domí } \\
\text { nios isóticos vermelho- } \\
\text { escuro }(20 \%) \text {, e silas- } \\
\text { sépico vermelho (10\%), } \\
\text { argila mineralógica e } \\
\text { óxidos de ferro. } \\
\end{array}$ & $\begin{array}{l}30 \% \text {, vermelho amarelo } \\
\text { silassépico dominante } \\
(60 \%) \text {, com dominios } \\
\text { isóticos vermelho-escuro } \\
(35 \%) \text { e silassépico ver- } \\
\text { melho (5\%). }\end{array}$ \\
\hline Esqueleto & $\begin{array}{l}45 \% \text {, domínio de quartzo } \\
\text { médio ( } 200 \mu \mathrm{m}) \text { subarre- } \\
\text { dondado nas frações mais } \\
\text { grosseiras e subangulares na } \\
\text { fina e muito fina. }\end{array}$ & $\begin{array}{l}40 \% \text {, dominio de quartzo } \\
\text { médio ( } 250 \mu \mathrm{m}) \text { subarre- } \\
\text { dondado nas fraçes média } \\
\text { e grossa e subangu-lares na } \\
\text { fina e muito fina. Presença } \\
\text { de poucos feldspatos. }\end{array}$ & $45 \%$, idem & $\begin{array}{l}55 \%, \text { idem, dominando as } \\
\text { frações de } 300 \mu \mathrm{m} \text { de diâ- } \\
\text { metro. }\end{array}$ \\
\hline Poros & $\begin{array}{l}50 \%, \text { predomina porosidade } \\
\text { de arranjo e secundariamen- } \\
\text { te ortocavidades. }\end{array}$ & $\begin{array}{l}45 \% \text {, porosidade de arran- } \\
\text { jo e ortocavidades. Poucas } \\
\text { metacavidades. }\end{array}$ & $\begin{array}{l}30 \%, \text { porosidade } \\
\text { ortacavitaria dominante } \\
(60 \%) \text { com poucos } \\
\text { metacavidades }(10 \%) \mathrm{e} \\
\text { alguma porosidade de } \\
\text { arranjo }(30 \%) \text { nos } \\
\text { domínios gefúricos. }\end{array}$ & $\begin{array}{l}15 \% \text {, ortocavidades } \\
\text { dominante ( } 90 \% \text { ) oom } \\
\text { uma pequena porosidade } \\
\text { de arranjo }(5 \%) \text { e meta- } \\
\text { cavidades }(5 \%) \text {. }\end{array}$ \\
\hline Trama & $\begin{array}{l}\text { Quitônica e localmente } \\
\text { gefúrica }\end{array}$ & $\begin{array}{l}\text { Porfirica }(30 \%) \text { e gefúrica } \\
(60 \%) \text { com tendência chi- } \\
\text { tônica }(10 \%) \text {. }\end{array}$ & $\begin{array}{l}\text { Porfirica fechada ( } 40 \%) \\
\text { com pequeno desenvol- } \\
\text { vimento de poros, inter- } \\
\text { calada com porfirica } \\
\text { aberta e mais porosa } \\
\text { com tendência gefürica } \\
\text { localmente }(60 \%) \\
\end{array}$ & $\begin{array}{l}\text { Porfirica fechada (60\%) } \\
\text { com um pequeno desen- } \\
\text { volvimento poroso e } \\
\text { intercalada com portirica } \\
\text { aberta e mais porosa com } \\
\text { tendência gefúrica } \\
\text { localmente }(40 \%) \text {. }\end{array}$ \\
\hline Feições & $\begin{array}{l}\text { Presença de isotúbulos } \\
\text { circulares formados por } \\
\text { raizes e de diminutas } \\
\text { glébulas }(0,2 \mathrm{~mm}) \\
\text { irregulare e isóticas. }\end{array}$ & $\begin{array}{l}\text { Presença de isotúbulos } \\
\text { circulares e cutãs zonados } \\
\text { complexos, simples e } \\
\text { hematãs nos domínios } \\
\text { porfiricos fechados. }\end{array}$ & $\begin{array}{l}\text { Presença de pápulas } \\
\text { (10\% do plasma) e cu- } \\
\text { tans zonados complexos } \\
\text { associadas aos dominios } \\
\text { porfíricos fechados. }\end{array}$ & $\begin{array}{l}\text { Presença de pápulas (1\%) } \\
\text { do plasma) e ferriargilãs } \\
\text { de iluviação (<1\% do } \\
\text { plasma) }\end{array}$ \\
\hline
\end{tabular}

